\author{
UNIVERSIDADE DE SÃo PAULO \\ FACULdADE DE FILOSOFIA, LETRAS E CIÊNCIAS HuMANAS \\ DEPARTAMENTO DE SOCIOLOGIA \\ PROGRAMA DE PÓS-GRADUAÇÃO EM SOCIOLOGIA
}

Cristian CARLA Bernava

ViolênCia E FEMinino no Cinema Contemporâneo 


\author{
UNIVERSIDADE DE SÃO PAULO \\ FACUldADE DE FILOSOFIA, LETRAS E CIÊNCIAS HuMANAS \\ DEPARTAMENTO DE SOCIOLOGIA \\ PROGRAMA DE PÓS-GRADUAÇÃo EM SOCIOLOGIA
}

ViolênCIA E FEMinino no Cinema CONTEMPorÂNEO

\begin{abstract}
Cristian CARla Bernava
Dissertação apresentada ao

Programa de Pós-Graduação em Sociologia do Departamento de Sociologia da Faculdade de Filosofia, Letras e Ciências Humanas da Universidade de São Paulo, para obtenção do título de Mestre em Sociologia.
\end{abstract}

Orientador: Prof. Dr. Paulo Roberto Arruda de Menezes 


\begin{tabular}{|c|c|c|c|}
\hline Pagina: & Linha: & Onde se lê: & Leia-se: \\
\hline 178 & 18 & ao & no \\
\hline 179 & 11 & garota & garota \\
\hline 179 & nota 2 & p.107, 1995, p.120. & 1995, p.107 e p.120. \\
\hline 179 & nota 3 & saberá-se & saber-se-á \\
\hline 180 & 6 & Pai-Mei & Pai Mei \\
\hline 180 & 8 e 11 & ao & no \\
\hline 181 & 16 & quanta & enquanto \\
\hline 182 & 4 & Kill Bill Vol. 1 & Kill Bill Vol. 1 \\
\hline 182 & nota 6 & op. cit., p.123 & op. cit., 1995, p.123 \\
\hline 183 & 18 & possa-se & se possa \\
\hline 184 & 9 & extra-ordinaria & extraordinária \\
\hline 186 & 12 & Saberá-se & Saber-se-á \\
\hline 189 & 23 & contrapõem & contrapõe \\
\hline 189 & nota 14 & implementada & implementado \\
\hline 191 & 2 & são & é \\
\hline 192 & 32 & masculinos & femininos \\
\hline 194 & 31 & Bil & Bill \\
\hline 194 & nota 17 & domintrix & dominatrix \\
\hline 196 & 14 & dos & nos \\
\hline 196 & 22 & sabe-se & se sabe \\
\hline 197 & 9 & sabe-se & se sabe \\
\hline 199 & 5 & vê-se & se vê \\
\hline
\end{tabular}




\section{ViolênCia E Feminino no Cinema Contemporâneo}

RESUMO: Este trabalho investiga a associação entre a violência e o feminino no cinema contemporâneo. Em virtude das mudanças nas formas de apresentação da violência feminina no cinema dos últimos anos, a primeira parte deste trabalho dedica-se, a partir das análises de Sedução e Vingança e Valente, a percorrer os caminhos que permitem considerar a especificidade do imaginário cinematográfico relativo à violência feminina e emergência de um novo tipo de personagem feminino, a guerreira, expressão do embate discursivo em torno da feminilidade da violência. Na segunda parte deste trabalho, composta pela análise dos filmes em que três personagens-ícone do período aparecem - Nikita, Lara Croft e Beatrix Kiddo -, dedica-se a chamar a atenção para as transformações e contradições que permeiam as diferentes caracterizações da guerreira.

Palavras-chave: violência; feminino; cinema contemporâneo; sujeito; abjeto.

\section{Violence ANd Femininity in CONTEMPORARY Cinema}

ABSTRACT: This research investigates the connection between femininity and violence in contemporary cinema. While considering the changes in which female violence has been portrayed in recent years, the first part of the work explores, through the analysis of Ms. 45 and The Brave One, the particularity of female violence cinematographic imagery and the emergence of a new kind of character, the warrior. The second part analyses the movies that featured three distinct icons of this period - Nikita, Lara Croft and Beatrix Kiddo - exploring the transformations and contradictions relative to the stereotypical female violence aspects presented in these different warriors.

KEY WORDS: violence; femininity; contemporary cinema; subject; abject. 
Para Beatriz 
Só escrevemos na extremidade de nosso próprio saber, nesta ponta extrema que separa nosso saber e nossa ignorância $e$ que transforma um no outro.

Gilles Deleuze 


\section{SUMÁRIO}

AgRAdeCIMENTOS, 7

CONSIDERAÇÕES INICIAIS, 10

PARTE I: Dois “MOMEnTOS” DA CONSTRUÇÃO DA VIOLÊNCIA PElO CINEMA CONTEMPORÂNEO (1981/2007), 12

CAPÍtUlo I - A ViolÊNCIA FEMININA COMO RETALiAÇÃo EM SEDUÇÃo E VINGANÇA E VALENTE, 13

THANA E A SEXUALIZAÇÃO DA VIOLÊNCIA NA CIDADE, 13

ERICA E O ESTEREÓTIPO EM TORNO DA VIOLÊNCIA FEMININA, 42

A temÁtica da RETALiaÇão EM SEDUÇÃo E VINGANÇA E VALENTE, 64

CAPÍtUlo II - O SURGimento DA GUERREIRA COMO PERSONAGEM CINEMATOGRÁFICO, 67

OS FEMININOS DO CINEMA: ALGUNS TIPOS DE PERSONAGENS, 70

A FEMINILIDADE DA VIOLÊNCIA, 83

PARTE II: VIOLÊNCIA E FEMININO NO CINEMA CONTEMPORÂNEO (1990-2004), 92

CAPÍTULO III - NiKITA, 93

CAPÍTULO IV - LARA CROFT, 130

SEXO, VIOLÊNCIA E PODER EM LARA CROFT, 130

AS ORIGENS DE LARA CROFT, 142

A CONSOLIDAÇÃO DE LARA COMO HEROÍNA, 157

O FEMININO E OS MASCULINOS DE LARA CROFT TOMB RAIDER, 169

CAPÍTULO V - BEATRIX KIDDO, 178

NOTAS FinAIs, 200

BIBLIOGRAFIA, 205

FILMOGRAFIA PRINCIPAL, 211

Filmografia DE APOIO, 212 


\section{Agradecimentos}

Foram muitas as pessoas que me apoiaram no longo percurso que culmina nesta dissertação. A todos aqueles de quem, neste momento, não pude me lembrar, minhas desculpas e meus sinceros agradecimentos.

Agradeço aos membros do Departamento de Sociologia e do Programa de PósGraduação em Sociologia da USP a acolhida a esta pesquisa, e ao CNPq o apoio financeiro que tornou possível sua realização.

Ao Professor Paulo Menezes, orientador há tantos anos, agradeço a jornada. Seria impossível elencar aqui todos os motivos, já ditos e ainda não-ditos, que fazem com que eu lhe seja sempre e profundamente grata. Pela seriedade, dedicação, paciência e respeito mostrados a cada leitura e a cada debate, pelo apoio nos momentos difíceis e pela celebração dos felizes, muito obrigada.

Agradeço aos Professores Mauro Luiz Rovai e Fraya Frehse as valiosas contribuições dadas durante o exame de qualificação. Ao Professor Mauro Rovai agradeço, também, a generosidade com que me recebeu por ocasião da conclusão da disciplina oferecida por ele na Universidade Estadual de Campinas há seis anos. Eu não poderia imaginar que, passado todo este tempo, estaria ainda discutindo os desdobramentos do trabalho final daquele curso. Pelo encorajamento e por despertar em mim a vontade de conhecer o que me trouxe até aqui, minha sincera gratidão.

À Professora Vera da Silva Telles e aos colegas do Seminário de Projetos agradeço os comentários e questionamentos feitos sobre o projeto original. Devo à Professora Vera muitos dos rumos tomados durante a pesquisa. Outros tantos devo à Professora Maria Helena Oliva Augusto. Por me apresentar à grande parte das questões que me movem e pelo carinho com que me recebe a cada encontro, obrigada.

Aos funcionários do Programa de Pós-Graduação em Sociologia, Maria Angela Ferraro de Souza e Vicente Sedrângulo Filho, agradeço o apoio em momentos decisivos e a acolhida com que sempre me atenderam.

Agradeço a leitura atenta, a crítica inspiradora e as sugestões bibliográficas aos colegas que compartilharam comigo tantos encontros do grupo do Paulo: Anderson Trevisan, Caio Pompeu, Daniela Dumaresq, Edilson A. Saçashima, Flavia Brites Martins, Jefferson Gomes, Lilian Victorino, Maíra Saruê Machado, Marina Soler, Michel Nasser A. Mustafa, Michele Nori Perusso, Michelle Urcci, Paulo Scarpa e Túlio 
Rossi. Fora do grupo do Paulo, Denise Adell, João de Freitas e Yara Mitsuishi também discutiram comigo alguns dos capítulos deste trabalho. João de Freitas e Yara Mitsuishi ajudaram-me também com a revisão do texto final. A todos, pela generosidade das contribuições, muito obrigada.

Ao Paulo Cunha e ao Paulo Scarpa agradeço especialmente a ajuda com os filmes. Obrigada também ao Burçin Kılıcak por me ajudar com as imagens do primeiro capítulo.

Sou grata à Ayexa García Ibarra por me receber tão afetuosamente em Morélia, por ocasião do Quinto Congreso Internacional de Teoría y Análisis Cinematográfico. Sou-lhe grata também pela revisão da tradução do texto de minha apresentação. Agradeço também à Giovana Manfredi a acolhida na cidade do Rio de Janeiro, durante o XIV Congresso Brasileiro de Sociologia.

Aos membros da Plural 15 e Plural 16 agradeço a experiência do fazer junto, do querer mais da revista dos alunos do Programa, e todo o empenho em fazer e refazer, sabe-se lá quantas vezes, até vingar. Aos Professores Leopoldo Waizbort e Nadya Araújo Guimarães, agradeço o apoio ao projeto de editoração eletrônica da Plural.

Numa turma de poucas pesquisadoras, agradeço à Bruna Gisi, à Denise Adell e à Marcela Ruffato as horas compartilhadas, a amizade e o companheirismo. Com cada uma de vocês vivi muitos dos melhores momentos deste percurso. Ao Danilo França, ao Eduardo Bonaldi, ao Max Brunner e ao Rogério Barbosa agradeço a alegria de todos os encontros, as conversas sérias e os risos frouxos, tão característicos da famosa sociabilidade de botequim. Ao Gustavo Taniguti, o desprendimento. Ao Alexandro Paixão e ao Anderson Trevisan, o cuidado e a companhia. Ao João de Freitas, a doçura e a surpresa do encontro. Ao Manoel Negraes, o abrir de horizontes e as referências bibliográficas sobre a questão da deficiência. A todos os meus novos amigos, obrigada.

Aos amigos antigos, companheiros para todas as horas, minha mais sincera e profunda gratidão. À Ana Lúcia Teixeira, à Flavia Brites Martins, ao Paulo Cunha, à Yara Mitsuishi, muitíssimo obrigada por estar em minha vida, por dividir e refletir comigo as incertezas, os acontecimentos, o banal e o extraordinário de cada um de nós.

A todos que tomaram conta de Beatriz para que eu pudesse trabalhar serei sempre muitíssimo grata. Flavia Brites e Paulo Cunha são, sem dúvida alguma, os melhores tios que Beatriz poderia ter. Minha dívida com vocês é imensa, sem o seu apoio meu primeiro ano de mestrado seria impossível. Sou também profundamente grata à Cecília Mori por toda a ajuda e carinho ao longo dos anos. À Maria Carolina 
Macari agradeço a generosidade com que sempre recebeu Beatriz em sua casa.

Por fim, por nunca deixar de acreditar que era possível, por me fazer recuperar a força e o desejo nas vezes que esmoreceram e, assim, me fazer prosseguir até o final, toda a minha gratidão à Mary Shoptaw. Obrigada por compartilhar comigo este momento e os outros que virão. 


\section{CONSIDERAÇõES INICIAIS}

Diferente da maioria de estudos acadêmicos, em que a apresentação da estrutura do trabalho destina-se a despertar o interesse do leitor, num estudo interpretativo sobre o cinema, como este, ela mais parece ameaçá-lo. A situação é parecida com aquela em que alguém conta os detalhes da história de um filme, ou pior ainda, de seu desfecho, para uma pessoa que ainda não o assistiu. Para alguns espectadores, saber o que acontece mina seu interesse pelo filme, coloca a experiência cinematográfica em xeque. Neste caso, o que acontece torna-se mais importante do que como acontece. Ainda que este seja um estudo sobre como acontece o que acontece, a maneira como se organiza o trabalho tratou de levar esta particularidade em consideração. Os limites de tal proposta serão, seguramente, desvelados nos parágrafos e páginas seguintes. Por ora, assumemse os riscos do relato do que acontece até o fim desta história.

Como o próprio título anuncia, este trabalho trata das associações entre violência e feminino no cinema contemporâneo. Por contemporâneo compreendeu-se um "momento" do cinema que se inicia na década de 1990 e perdura até os dias atuais, em que ocorre uma diversificação das formas de apresentação - e, consequentemente, dos significados - da violência feminina na tela. Este "momento" não se caracteriza, portanto, pela completa superação das formas "anteriores" de apresentação da violência feminina no cinema, embora seja necessário debruçar-se sobre os elementos que apontam para as transformações que se puseram em curso no período. A primeira parte deste trabalho dedica-se, então, a construir estes dois "momentos". O Capítulo I apresenta as análises de Sedução e Vingança e Valente, chamando atenção para as transformações nas formas de apresentação da violência feminina em filmes que são considerados, por alguns, como pertencentes a uma mesma temática, a da retaliação. A partir destas análises, o Capítulo II dedica-se a percorrer os caminhos que permitem considerar a emergência de um novo tipo de personagem feminino, a guerreira, expressão do embate discursivo em torno da feminilidade da violência no cinema contemporâneo.

Na segunda parte deste trabalho, composta pela análise dos filmes em que três personagens-ícone deste "momento" aparecem - Nikita, Lara Croft e Beatrix Kiddo -, dedica-se a chamar a atenção para as transformações e contradições que permeiam as diferentes caracterizações da guerreira. Tais personagens-ícone, mais que serem 
compreendidos como subtipos, expressam diferentes questionamentos no interior da temática. Neste sentido, ainda que nesta parte do trabalho as análises estejam organizadas cronologicamente, os diferentes questionamentos promovidos pela figura da guerreira não devem ser considerados como reflexo de um desenvolvimento linear ou progressivo deste tipo de personagem. 
PARTe I:

DOIS “MOMENTOS” DA CONSTRUÇÃO DA VIOLÊNCIA FEMININA PELO CINEMA CONTEMPORÂNEO (1981/2007) 


\section{CAPítulo I - A ViolênCIA FEMinina COMO RETAliaÇão EM SEDUÇão E VINGANÇA E VALENTE}

Neste capítulo Sedução e Vingança (Angel of Vengeance, Abel Ferrara, 1981) e Valente (The Brave One, Neil Jordan, 2007) são analisados a partir de uma abordagem que coloca as imagens dos filmes como primordiais ao exercício de interpretação. Para tanto, num primeiro momento, são abordados os aspectos pertinentes a construção das narrativas em questão e das relações propostas em cada um dos filmes. Num segundo momento, são discutidas suas principais diferenças e similaridades, de modo a problematizar em que medida estes filmes podem ser considerados como momentos de uma mesma temática, a da retaliação, e a importância que tem uma ideia de retaliação quando se aborda a violência feminina no cinema das últimas décadas.

\section{THANA E A SEXUALIZAÇÃO DA VIOLÊNCIA NA CIDADE}

A apresentação de Sedução e Vingança é bastante breve. O primeiro contato com o filme se dá através de uma melodia tocada ao piano acompanhada por um fundo de tela preta. Lenta no início, a melodia começa a ganhar ritmo e intensidade conforme outros instrumentos musicais passam a ser ouvidos e veem-se os créditos iniciais aparecem e desaparecem da tela em letras brancas. Os primeiros créditos referem-se à equipe técnica e de produção. A música tem um tom sombrio que vai se transformando em de suspense, cujo maior ponto de tensão se estabelece após a apresentação do último crédito, que vincula a atriz principal ao título do filme ${ }^{1}$. A aparição do título do filme

1 O filme foi lançado nos EUA com o título de $M s$. 45. A versão utilizada nesta análise foi a lançada no Brasil em VHS, que utiliza o título alternativo Angel of Vengeance. Tive acesso também à apresentação do filme que utiliza o título original. Neste caso, o título aparece na tela palavra por palavra e não de uma só vez como na que utiliza o título alternativo, e há a gravura de um buraco feito por um disparo que atinge a tela perto do ponto da abreviação de "Ms." ao fim dos disparos. Ainda neste caso, o título do filme mescla-se através de um fade in na sequência seguinte, que apresenta o local a partir de onde a narrativa se desenvolve. Na versão que utiliza o título alternativo, há uma dissolução entre a apresentação do título do filme e a sua primeira sequência. Segundo Jean-Claude Carrière, "o fade in - uma dupla exposição temporária, de duração variável, dos últimos quadros de uma tomada e dos primeiros da próxima - sempre significou um salto no tempo, mas pequeno". Carrièrre, Jean-Claude, A linguagem secreta do cinema. Rio de Janeiro: Nova Fronteira, 1995, p. 116; grifos do autor. Já a dissolução ou fade out é outra técnica utilizada para recortar ou indicar a passagem do tempo em um filme: "a dissolução - o gradual desaparecimento de uma imagem que mergulha na escuridão - invariavelmente significa um corte mais longo [no tempo]". Carrière, JeanClaude, op. cit., 1995, p. 116. 
quebra o ritmo da apresentação através da introdução de ruídos de disparos de uma arma de fogo. A seguir, vê-se uma grande cidade, a partir de um cruzamento onde podem ser observados pedestres, carros e caminhões, em meio a uma paisagem de grandes edifícios e estabelecimentos comerciais. A imagem do cruzamento é acompanhada por ruídos de carros e buzinas. Um intertítulo anuncia que o local se trata do Garment Center de Manhattan ${ }^{2}$ e, ao atentar para a estética dos veículos, pode-se identificar o momento da captura das imagens como próximo ao do lançamento do filme, 1981. Assim, a imagem da cidade apresenta o recorte espaço-temporal da história. Somada aos indícios da primeira parte da apresentação, percebe-se que a história de Sedução e Vingança se desenrolará tendo como pano de fundo a violência urbana.

A narrativa de Sedução e Vingança pode ser dividida em três partes de durações desiguais. Na primeira, a protagonista é introduzida no enredo a partir de seu ambiente de trabalho, um ateliê de costura. No caminho de volta para casa, é estuprada por um homem mascarado que a ameaça com uma arma e a arrasta para o interior de um beco. Já em seu apartamento, defronta-se com um ladrão, que a estupra pela segunda vez. Diferente do que acontece durante o primeiro estupro, Thana tem a chance de reagir no momento em que o invasor, tendo um orgasmo, deixa cair a arma. Acerta-o com um peso de papel duas vezes e, por fim, mata-o com o ferro de passar roupas. A protagonista apresenta distúrbios devido aos acontecimentos, mas não demonstra remorso. Esquarteja o corpo do invasor e decide jogar as partes no lixo, em diferentes lugares da cidade. Numa dessas ocasiões, é seguida por um jovem e mata-o quando ele finalmente se aproxima tentando devolver-lhe a sacola que abandonara na rua. Os dois primeiros assassinatos cometidos por Thana apresentam-se como uma reação. Não podem ser lidos como acidentes ${ }^{3}$, mas têm um caráter diferente dos assassinatos que cometerá depois. Apenas quando Thana usa a arma do invasor sua caracterização como assassina torna-se completa.

$\mathrm{Na}$ segunda parte do filme, Thana transforma-se inegavelmente em uma

2 O Garment District de Manhattan localiza-se entre a $5^{\mathrm{a}}$ e a $9^{\mathrm{a}}$ avenidas, das ruas 34 à 42 . Nesta área estabeleceram-se estilistas de moda e indústrias de confecções desde o fim do século XIX, configurando-se como o centro da moda estadunidense por grande parte do século XX. No fim do século XX, no entanto, a atividade na área começou a declinar, apesar de ainda abrigar um número significativo de ateliês, estilistas e showrooms da indústria de confecções. Cf. http://www.tenement. org/encyclopedia/garment.htm; página acessada em 15/07/2008.

3 No primeiro assassinato, ela agarra o peso de papel antes do invasor deixar cair a arma, esperando um momento propício para reagir. No segundo, apesar de ainda não estar à caça de vítimas, sai de posse da arma do invasor e não hesita em utilizá-la. 
assassina, agindo de forma premeditada. Interage com homens em diversas situações para assassiná-los, ou os escolhe ao vê-los interagir com outras mulheres pelas ruas da cidade. Nesta parte do filme, Thana assassina um fotógrafo de moda, um cafetão, cinco integrantes de uma gangue de rua e um sheik árabe.

$\mathrm{Na}$ terceira e última parte do filme, suas tentativas de homicídio encontram alguns revezes, como a vítima que lhe escapa em Chinatown e o marido traído que se apossa da arma de Thana depois de vê-la falhar e se suicida. Também nesta parte do filme a zeladora de seu prédio, já desconfiada das mudanças em seu comportamento, acaba descobrindo a cabeça do invasor dentro de um saco plástico no armário do apartamento de Thana e chama a polícia. Antes que os policiais possam encontrá-la, Thana encontra a "redenção" em um grito de morte, após chacinar grande parte dos homens presentes na festa de Halloween de sua equipe de trabalho, incluindo seu chefe.

Como apontado na apresentação do filme, a cidade de Nova Iorque aparece como o recorte espacial primordial da narrativa. Durante o dia, ora vê-se uma cidade com as mesmas características apresentadas no início do filme, ora vê-se espaços relativamente vazios e muitas vezes, sombrios. Nova Iorque parece ser uma cidade de becos onde, à noite, impera a escuridão. Um espaço que, portanto, favorece a criminalidade. Referências como o Central Park, Chinatown e nomes de estações de metrô, ruas e avenidas legitimam a construção da cidade. Os cenários que remetem a espaços internos, tais como o do apartamento de Thana e da zeladora de seu prédio, a Sra. Nasone, são pequenos e sem sofisticação, indicando a condição social pouco privilegiada dos personagens. Com exceção do apartamento da Sra. Nasone, onde se pode ver badulaques por todos os cantos, o apartamento de Thana e o ateliê de costura apresentam poucos aparatos e móveis.

A estrutura da narrativa não deixa evidente em quanto tempo se passa a história, mas algumas marcações referentes à passagem dos dias são utilizadas, todas de conteúdo. A primeira delas se dá pela contraposição entre o espaço do apartamento de Thana e do ateliê de costura, como meios de separar o tempo de trabalho e o tempo de não-trabalho. As saídas de Thana com os sacos de lixo funcionam também como marcações de tempo, mas nem sempre se relacionam ao início de um novo dia. Em terceiro lugar, quando Thana passa a sair à noite para procurar suas vítimas, o retorno a seu apartamento é novamente utilizado para marcar a passagem do tempo. Nestes casos, 
a luz do dia pode ser vista através de janelas ou a partir da entrada de seu prédio ${ }^{4}$. Além disso, uma quarta marcação da passagem dos dias pode ser percebida através das roupas utilizadas por Thana e da maneira cada vez mais carregada com que se maquia para ir ao trabalho. Albert, seu chefe, é quem revela que o passar dos dias se dá de forma linear, mas não consecutiva, ao chamar atenção de Thana por não ter retornado ao trabalho na sexta-feira após o almoço - dia em que assassina o fotógrafo -, sem que se tenha presenciado os acontecimentos de todo o final de semana. De modo geral, percebe-se que não se passa muito tempo entre os estupros e a festa de Halloween em que Thana é morta.

A estrutura da narrativa de Sedução e Vingança é organizada a partir da montagem de planos de curta e média duração. Segundo André Bazin, é a montagem que organiza as imagens no tempo de um filme, atribuindo-lhes a forma de linguagem ${ }^{5}$. Para Sergei Eisenstein, a montagem no cinema constitui-se como um caso particular de aplicação do princípio geral de montagem presente em artes como a literatura e a pintura, superando o que seria uma mera colagem de fragmentos de filme ${ }^{6}$. Segundo este autor, ela constitui-se como uma maneira de expressão eficaz também no cinema, uma vez que permite uma exposição logicamente coesa e emocionalmente estimulante da história ou tema construído como imagem ${ }^{7}$, através da agregação e justaposição de eventos, fenômenos ou objetos apresentados, que engendra uma correlação independente da presença ou ausência de uma relação anterior entre eles, sendo determinada tanto pelo plano quanto pela montagem:

estamos acostumados a fazer, quase que automaticamente, uma síntese dedutiva definida e óbvia quando quaisquer objetos isolados são colocados à

Como as saídas noturnas de Thana começam após a noite do pesadelo e ela retorna sempre de manhã, é possível que o personagem já não seja mais capaz de dormir.

5 Por imagem, Bazin entende "tudo aquilo que a representação na tela pode acrescentar a coisa representada". Bazin, André. "A evolução da linguagem cinematográfica". In: O Cinema Ensaios. São Paulo: Brasiliense, 1991a, p. 67; grifos do autor.

Cf. Eisenstein, Sergei. O sentido do filme. Rio de Janeiro: Jorge Zahar Editor, 1990, p. 29.

7 Para Eisenstein, a imagem é formada na memória pela vinculação de uma série de representações particulares e independentes em uma cadeia que é percebida de modo total. Quanto mais tal imagem é assimilada pela memória, menos uma pessoa dá-se conta dos elementos que a compõem, de modo que a imagem the aparece como imagem total. Cf. Eisenstein, Sergei, op. cit, 1990, pp. 19-20. As definições de imagem de Eisenstein e de Bazin aparecem ancoradas sobre o conceito de representação. Para uma problematização do uso deste conceito em relação à experiência cinematográfica, ver: Menezes, Paulo. "O Cinema Documental como 'Representificação': verdades e mentiras nas relações (im)possíveis entre representação, documentário, filme etnográfico, filme sociológico e conhecimento". In: Novaes, Sylvia Caiuby [et al.] (orgs.). Escrituras da imagem. São Paulo: Fapesp: Edusp, 2004, pp. 21-45. 
nossa frente lado a lado. Por exemplo, tomemos um túmulo, justaposto a uma mulher de luto chorando ao lado, e dificilmente alguém deixará de concluir: uma viúva ${ }^{8}$.

A justaposição se apresenta, dessa maneira, como uma "terceira coisa", não como a soma de planos, mas como o produto deles, uma vez que "em toda justaposição deste tipo o resultado é qualitativamente diferente de cada elemento considerado isoladamente"10. Esta "terceira coisa" aparece, então, como a imagem total do filme, suscitando no espectador - nas suas memória e percepção - a mais completa imagem do tema ${ }^{11}$.

Neste caso, cada fragmento de montagem já não existe mais como algo nãorelacionado, mas como uma dada representação particular do tema geral, que penetra igualmente todos os fotogramas. A justaposição desses detalhes parciais em uma dada estrutura de montagem cria e faz surgir aquela qualidade geral em que cada detalhe teve participação e que reúne todos os detalhes num todo, isto é, naquela imagem generalizada, mediante a qual o autor, seguido pelo espectador, apreende o tema ${ }^{12}$.

Talvez porque as imagens sejam percebidas na sua totalidade, o espectador nem sempre percebe as descontinuidades espaço-temporais e as diferentes estratégias de montagem ${ }^{13}$ que estabelecem as relações entre os diferentes planos e sequências de uma narrativa cinematográfica. Não raro, como afirma André Bazin ao referir-se ao cinema clássico norte-americano, a lógica utilizada na montagem a torna, por vezes, "invisível"14:

8 Eisenstein, Sergei, $O$ sentido do filme, op. cit., 1990, p. 14; grifos do autor.

9 A problematização da expressão através do uso das aspas é feita por Eisenstein e incorporada aqui. Cf. Eisenstein, Sergei, op. cit., 1990, p. 16 e p.17.

10 Eisenstein, Sergei, op. cit., 1990, p. 16; grifos do autor. Impossível aqui não lembrar o experimento de Kuleschov, tantas vezes discutido na bibliografia sobre cinema e também discutido por Bazin, André, "A evolução da linguagem cinematográfica", op. cit., 1991a, p. 68.

11 Cf. Eisenstein, Sergei, $O$ sentido do filme, op. cit., 1990, pp. 14-18.

12 Eisenstein, Sergei, op. cit., 1990, p. 17; grifos do autor.

13 No que se refere à montagem, Bazin aborda a montagem paralela criada por Griffith, a montagem acelerada criada por Abel Glance e a montagem de atrações criada por Eisenstein como possibilidades de montagem; todas elas têm como característica comum a criação de um sentido que advém da relação entre as imagens e não delas mesmas. Cf. Bazin, André, "A evolução da linguagem cinematográfica", op. cit., 1991a, pp. 67-68.

14 A problematização do termo "invisível" pelo uso das aspas foi incorporada a partir de: Bazin, André, op. cit., 1991 a, p. 67. 
os cortes dos planos não têm outro objetivo que o de analisar o acontecimento segundo a lógica matemática ou dramática da cena. É sua lógica que torna tal análise insensível; o espírito do espectador adota naturalmente os pontos de vista que o diretor lhe propõe, pois são justificados pela geografia da ação ou pelo deslocamento do interesse dramático ${ }^{15}$.

A adoção dos pontos de vista propostos numa narrativa pelo espectador não se configura como um problema para Eisenstein. Ao contrário, para ele, daí advém a força da montagem. É a partir dela que o espectador insere-se no processo criativo que deu origem à narrativa, experimentando e criando uma imagem própria a partir de sua individualidade e da orientação plástica sugerida pelo realizador de cinema ${ }^{16}$.

A montagem, tal qual concebida por Eisenstein, apresenta-se, assim, como um processo dinâmico,

que reside basicamente no fato de que a imagem desejada não é fixa ou já pronta, mas surge - nasce. A imagem concebida por autor, diretor, e ator é concretizada por eles através dos elementos de representação independentes, e é reunida - de novo e finalmente - na percepção do espectador. Este é, na realidade, o objetivo final do esforço criativo de todo artista ${ }^{17}$.

Neste sentido, a montagem é construída de modo a alcançar "a forma de maior expressividade e de maior atividade emocional, usando a forma simples e econômica no limite daquilo que expressa o que nos é necessário"18.

Isto ocorre após a sequência em que Thana queima a ferro um tecido no ateliê de costura. A sequência seguinte mostra um senhor cego em uma esquina da cidade, um jovem abordando as mulheres que passam por eles na mesma esquina e Thana, ao longe, descendo de um táxi com uma sacola nas mãos. A roupa usada por Thana parece ser a mesma que usara no ateliê, assim, entende-se que ela dispôs-se a livrar-se de mais um pedaço do corpo do invasor depois do trabalho. No entanto, ela não é vista deixando o

Bazin, André, op. cit., 1991a, p. 67.

16 Cf. Eisenstein, Sergei, O sentido do filme, op. cit., 1990, p. 27-28.

17 Eisenstein, Sergei, op.cit, 1990, p. 27; grifos do autor.

18 Eisenstein, Sergei. "Novos problemas da forma cinematográfica". In: Xavier, Ismail (org.). A experiência do cinema: antologia. Rio de Janeiro: Graal: Embrafilmes, 1983, p. 240; grifos do autor suprimidos. 
ateliê, nem se sabe se ela antes passara em casa para apanhar a sacola. Estes acontecimentos já não são importantes para o desenvolvimento da narrativa, bastando criar as condições que justifiquem o segundo assassinato a ser cometido pela protagonista.

Ao propor uma continuidade espaço-temporal através de diversas estratégias de montagem, a estrutura narrativa de Sedução e Vingança se apresenta de forma linear. A linearidade da narrativa aparece preservada mesmo durante o pesadelo de Thana, na noite após o segundo assassinato. Nele, podem-se ver imagens do rosto mascarado do primeiro estuprador, da geladeira onde ela guardara os sacos de lixo com os pedaços do corpo do invasor, seu braço decepado sobre o jornal, o invasor deitado na banheira, intercalados através de múltiplos fade in $(s)$ com imagens de Thana rolando na cama. Apesar da dimensão temporal do filme ser rompida pela repetição de planos que remetem a um tempo passado da história, a linearidade de tempo é preservada pela inserção das imagens de Thana no tempo presente da narrativa. Assim, ao contrário do que sugere Rudolf Arnheim ${ }^{19}$ sobre a quebra da ordem do tempo de um filme pela apresentação de um sonho, a linearidade é preservada na sequência, que remete muito mais a uma perturbação psicológica da protagonista e a sua dificuldade de dormir que a um rompimento da dimensão temporal da narrativa. A sequência do pesadelo aponta, dessa maneira, para uma possível reorganização de descontinuidades temporais nas narrativas contemporâneas.

Isto acontece também no que tange as demais dissoluções e fade in $(s)$, que assumem propósitos distintos na narrativa. As primeiras são utilizadas para marcar a passagem de um curto período de tempo na história, geralmente em um mesmo dia, como o intervalo em que Thana esquarteja o corpo do invasor no banheiro e o momento em que guarda os sacos de lixo na geladeira, ou o intervalo que separa o momento do disparo contra a sua segunda vítima e o retorno a seu apartamento. Já os fade in(s) são utilizados para delimitar os momentos de sonho e de confusão mental, como na sequência em que Thana assiste o auxiliar de limpeza trocando o saco de lixo do ateliê $\hat{e}^{20}$, demonstrando sua perturbação através de uma crise nervosa e sendo, então, rodeada pelas demais funcionárias e por seu chefe. Técnicas que pareciam ameaçadas de extinção para autores com Jean-Claude Carrière ${ }^{21}$, as dissoluções e $\operatorname{fade}_{\text {-inn }(s)}$

19 Cf. Arnheim, Rudolf. A arte do cinema. Lisboa: Edições 70, s/d, p. 27.

20 Similar ao que ela usara para guardar as partes do corpo do invasor/estuprador em sua geladeira.

21 Cf. Carrière, Jean-Claude, A linguagem secreta do cinema, op. cit., 1995, pp. 116. 
aparecem aqui sendo utilizadas para construir os tempos da narrativa de uma maneira específica e própria, propondo sentidos que podem ser diferentes daqueles a que foram tradicionalmente associadas. Se antes o fade-in significava um salto pequeno de tempo, ele torna-se em Sedução e Vingança um artifício que marca e evidencia diferentes estados mentais no presente da narrativa, enquanto a dissolução assume a função que, supostamente, lhe caberia propor. Reorganizações como esta acontecem também em muitas outras narrativas contemporâneas, sendo que em cada uma delas faz-se uso dessas e de outras estratégias de maneira relativamente singular, o que sugere que por mais que tais procedimentos sejam convencionais, é a partir da maneira como cada narrativa se estrutura que lhes são atribuídos sentidos e significados.

Ao chamar atenção para a "invisibilidade" da montagem, Bazin traz à tona parte do arsenal de procedimentos e estratégias utilizados pelo cinema para propor ao espectador sentidos que as imagens não têm em si mesmas de modo a que se minimizem suas possíveis ambiguidades. A interpretação dos acontecimentos que se passam na tela pelo espectador depende, portanto, da relação que é estabelecida entre as imagens através da montagem e seu conteúdo plástico ${ }^{22}$.

Esta relação pode ser percebida durante a construção dos estupros. No primeiro, a proposição de que ocorre o estupro é dada pelo paralelismo entre $\operatorname{close}-u p(s)^{23}$ no rosto de Thana e nos movimentos do estuprador. Não se vê a violação, mas sabe-se que ela ocorre. A câmera posicionada à frente dos corpos de Thana e do estuprador, da direita para a esquerda da tela, focaliza o estuprador de baixo para cima, com a câmera inclinada, mostrando o perfil de seu rosto e tronco. Thana aparece no momento da rendição de cima para baixo, a câmera mostrando seu rosto e colo através da blusa rasgada.

22 Cf. Bazin, André, “A evolução da linguagem cinematográfica”, op. cit., 1991a, p. 68.

23 Segundo Ismail Xavier, no primeiro plano ou close-up, "a câmera, próxima da figura humana, apresenta apenas um rosto ou outro detalhe qualquer que ocupa a quase totalidade da tela". Xavier, Ismail. O discurso cinematográfico. A opacidade e a transparência. São Paulo: Paz e Terra, 2005, pp. 27-28. 

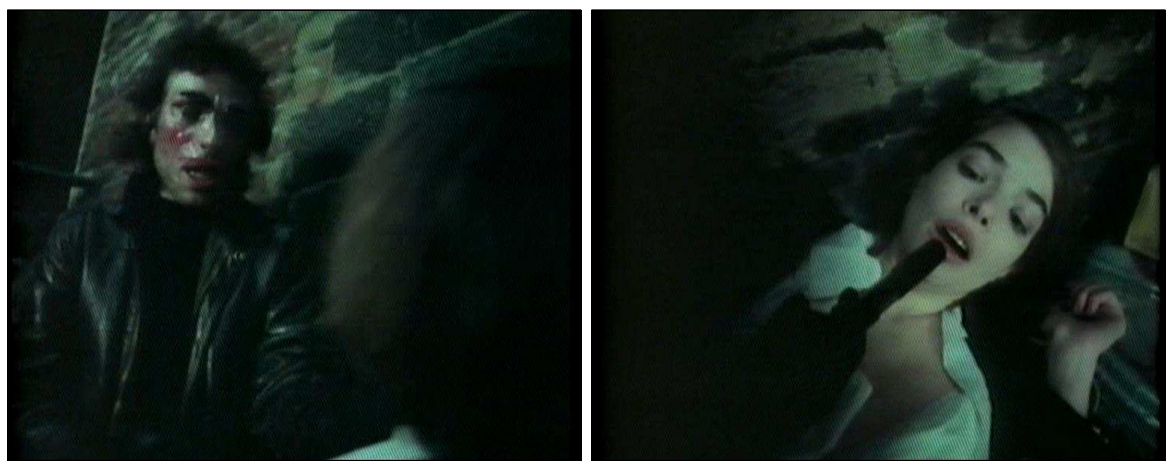

Grande parte do rosto do estuprador aparece recoberta por uma máscara que simula uma maquiagem carregada e borrada, em que um vermelho intenso predomina sobre o fundo branco em suas bochechas. Os lábios abertos e rosados de Thana destacam-se na palidez de seu rosto e colo. A arma direcionada à sua boca, que assume o lugar de seu sexo, alude à violação que ocorrerá ${ }^{24}$. Durante o estupro, a câmera focaliza Thana a partir da altura do perfil de seu rosto, em $\operatorname{close-up(s)}$ de maior duração, que privilegiam a identificação de Thana à condição de vítima: os olhos arregalados, as sobrancelhas arqueadas, a testa franzida e a boca aberta num grito mudo constroem a imagem do estupro, fazendo com que o espectador experimente a violação através das expressões faciais do personagem ${ }^{25}$.
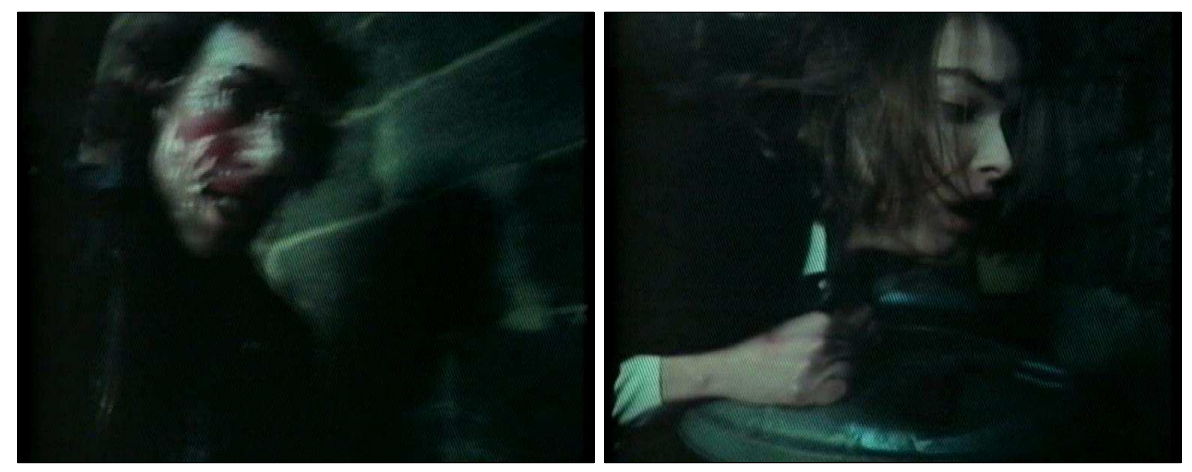

24 Não deixa de ser interessante que, enquanto o falo é substituído pela arma, ou seja, um objeto que alude a uma parte do corpo masculino, mas não lhe pertence, a genitália feminina é substituída pela boca.

25 O estupro da esposa do escritor que acontece em Laranja Mecânica (A Clockwork Orange, Stanley Kubrick, 1971) é construído de maneira similar, apesar de que, neste caso, são as expressões faciais do marido que aparecem na tela. A este respeito ver: Menezes, Paulo. À meia-luz: cinema e sexualidade nos anos 70. São Paulo: USP, Curso de Pós-Graduação em Sociologia: Ed. 34, 2001, pp. 49-79; Saçashima, Edilson Atsuo. A Questão da "Violência” no Cinema de Stanley Kubrick. Análise dos filmes Laranja Mecânica, Barry Lyndon e O Iluminado. São Paulo: Programa de Pós-Graduação em Sociologia, FFLCH-USP, Dissertação (Mestrado), 2007, pp. 81-106. 

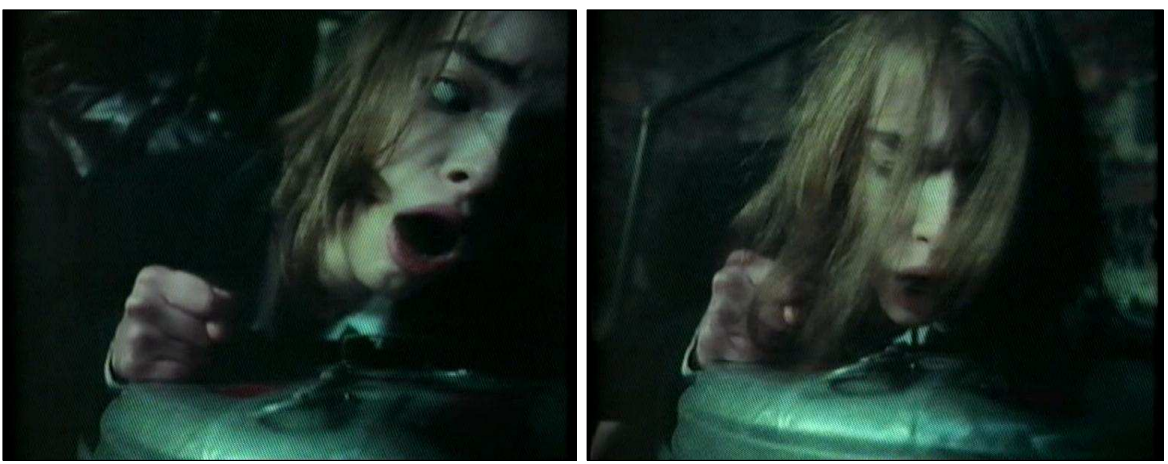

Ao fim, um plano alto e geral do beco mostra Thana sozinha, diminuída e desamparada.

O segundo estupro também é proposto através de um paralelismo entre imagens de Thana e do invasor/estuprador, mas os posicionamentos de câmera são diferentes, já que neste caso há uma maior proximidade física entre eles - no primeiro caso, o estuprador permanece em pé, no segundo, ele deita-se sobre ela. A câmera focaliza o estuprador de frente em close-up, a partir da altura de seu rosto. Sabemos que ela está embaixo dele, mas não vemos detalhes de seu corpo, que aparece apenas parcialmente na parte de baixo da tela.
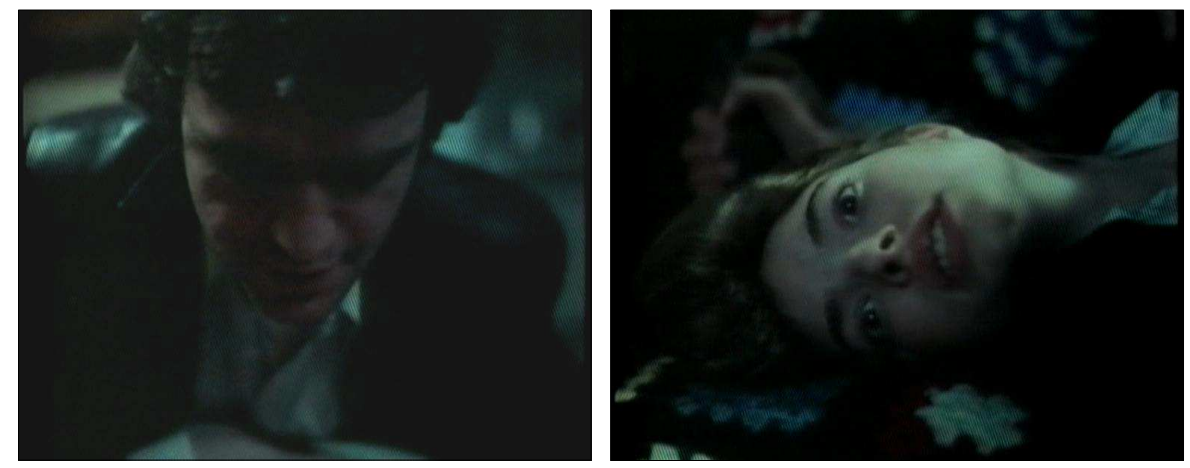

Há um momento, no entanto, em que a câmera se abaixa para mostrá-lo beijando-a, revelando ambos. Quando a câmera volta-se para ela, mostra seu rosto de frente, evitando o olhar do agressor, em close-up(s) que também omitem o rosto do estuprador. Diferentemente do primeiro estupro, são intercalados, na sequência, planos da mão de Thana agarrando e segurando o peso de papel, antecipando uma possível reação por parte dela. 

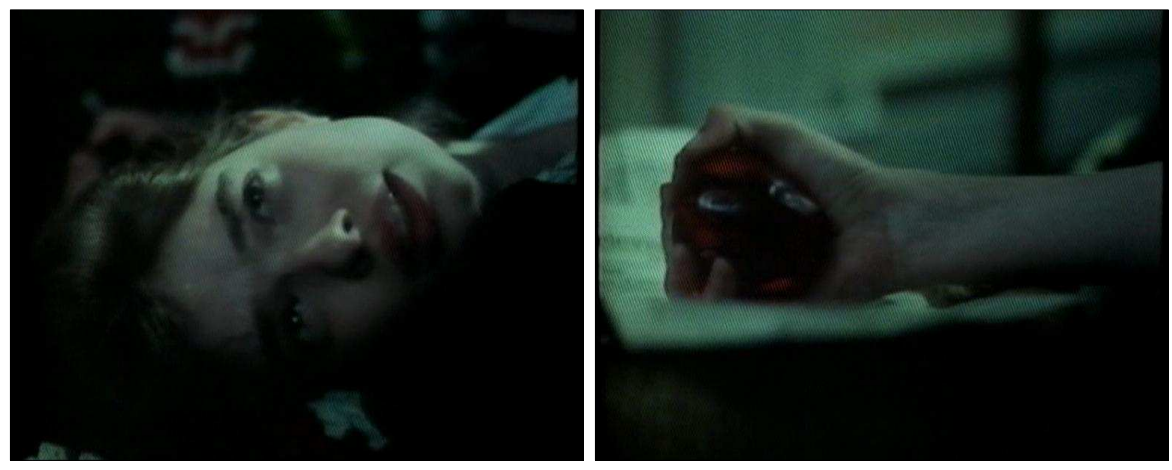

Apesar de na sua forma o close-up constituir-se com uma descontinuidade espacial, ele não é percebido como tal. Segundo Béla Balázs,

se o close-up isola algum objeto ou parte dele de seu ambiente, nós, ainda assim o percebemos no espaço; não esquecemos em momento algum que a mão, digamos, mostrada em close-up, pertence a algum ser humano. É precisamente esta ligação que empresta significado a cada um de seus movimentos ${ }^{26}$.

De acordo com Eisenstein, quando se substitui o todo pela parte através do close-up, consegue-se um efeito cuja intensidade emocional é muito maior do que seria se o todo fosse mostrado. "Não existe uma unidade entre todo e parte, mas por outro lado, logra-se uma identidade objetiva para a representação do todo e da parte"27.

A montagem paralela é utilizada também para propor a simultaneidade de acontecimentos em espaços diferentes. Segundo Bazin, "criando a montagem paralela, Griffith conseguia dar conta da simultaneidade de duas ações, distintas no espaço, por uma sucessão de planos de uma e da outra"28. A técnica é utilizada quando são mostrados planos de Thana fazendo compras em um supermercado, intercalados a planos de um homem invadindo e examinando um apartamento. A sequência propõe, dessa maneira, que é o apartamento dela que está sendo invadido.

Neste sentido, e de acordo com o argumento de Maurice Merleau-Ponty, o filme não é uma soma de imagens, mas sim uma forma temporal complexa. O sentido de uma imagem depende, por um lado, das imagens que a antecederam, sendo que a sucessão de

\footnotetext{
26 Balázs, Bela. “A face do homem”. In: Xavier, Ismail (org.). A experiência do cinema: antologia. Rio de Janeiro: Graal: Embrafilmes, 1983, p. 93; grifos do autor.

27 Eisenstein, Sergei, "Novos problemas da forma cinematográfica”, op.cit, 1983, p. 226.

28 Bazin, André, “A evolução da linguagem cinematográfica”, op. cit., 1991a, p. 67.
} 
imagens na tela cria uma realidade nova. Por outro lado, o sentido de uma imagem depende também da duração de cada plano e do consequente estabelecimento de um ritmo cinematográfico, de modo a que o todo a ser percebido seja capaz de produzir a impressão desejada no espectador com o máximo efeito. Considerando por sua vez os filmes sonoros, Merleau-Ponty argumenta que também em relação à banda sonora existe uma montagem e o estabelecimento de um ritmo próprios. Para o autor, a montagem sonora une-se à montagem das imagens de um filme através da organização dos sons, dos ruídos, do silêncio, dos diálogos e da música, devendo contribuir significativamente para a realização da experiência cinematográfica ${ }^{29}$. A união entre som e imagens se realiza, assim, no filme inteiro, consumando

(...) uma totalidade nova e irredutível, mediante os elementos que entram em sua composição. Um filme sonoro não é um filme mudo acrescido de sons e palavras, unicamente destinados a complementar a visão cinematográfica. O vínculo entre o som e a imagem é muito mais estreito e esta última se transforma com a proximidade do som. (...) A voz, o perfil e o temperamento formam um todo indivisível. Contudo, a união do som e da imagem não se realiza apenas em cada personagem e, sim, no filme inteiro. Não é por acaso que, em dado momento, as personagens se calam e, noutro, passam a falar: a alternância das palavras e do silêncio é conduzida com vistas ao maior efeito da imagem ${ }^{30}$.

Para Pierre Sorlin, ainda que os diversos elementos sonoros utilizados em um filme possam ser enumerados e categorizados, na maioria dos filmes contemporâneos os sons se apresentam como signos que remetem a toda uma sorte de convenções. Segundo o autor,

a sonorização dos produtos cinematográficos recentes, ainda que geralmente bem cuidada, desempenha-se sobre um registro muito pobre. Divide-se entre dois códigos principais, um indicativo, que dá as informações, e outro funcional, que serve para canalizar e orientar a recepção da mensagem pelo público. A maior parte dos elementos que entra nesses códigos pertence a um repertório cultural já antigo, e são imediatamente reconhecíveis. A este

${ }^{29}$ Cf. Merleau-Ponty, Maurice. "O cinema e a nova psicologia”. In: Xavier, Ismail (org.). A experiência do cinema: antologia. Rio de Janeiro: Graal; Embrafilmes, 1983, pp. 111-114.

30 Merleau-Ponty, Maurice, op. cit., 1983, pp. 112-113. 
conjunto trivializado, certas realizações somam um sub-código parcialmente autônomo (ruídos e, sobretudo, música) que lhes é próprio ${ }^{31}$.

Já a partir da apresentação de Sedução e Vingança pode-se perceber que a utilização conjunta da música, dos ruídos e sons - parte da montagem sonora, portanto apresenta-se como uma das estratégias fílmicas mais exploradas para a proposição dos sentidos nesta narrativa. A montagem sonora aparece, principalmente no que se refere à utilização da música e dos ruídos, como uma possibilidade de proposição de sentidos às ações, percepções e pensamentos, especialmente em relação a sua protagonista. Marc Ferro faz referência, ao analisar Chapaev - $O$ soldado vermelho (Yanaeb, Sergei Dimitrevitch e Georgi Nikolaevitch, 1934), que a música utilizada em uma sequência cinematográfica pode sublinhar a natureza dos sentimentos de um personagem ${ }^{32}$. Neste sentido, além de marcar mudanças circunstanciais no filme, a música fala muitas vezes por Thana, dando o tom dos acontecimentos e de suas emoções que ela, em sua mudez, não pode comunicar através de diálogos. Assim, dialeticamente, demoramos a perceber que o personagem é mudo. De início, sua mudez confunde-se com timidez e reserva. Apenas quando o primeiro estupro está em curso é que se compreende que ela não pode falar.

É principalmente a partir deste momento que, em Sedução e Vingança, o conjunto formado pela montagem de sons e de imagens, nas sequências que exploram os close-up $(s)$ de sua face, confere ao personagem de Thana emoções e vida interior, favorecendo sua identificação e a impressão de que "a expressão facial no rosto é completa e compreensível em si mesma e, portanto, não há necessidade de pensarmos nela como existindo no espaço e no tempo"33 da narrativa .

O mesmo pode ser dito a respeito de outros personagens do enredo. No entanto, nas sequências que se utilizam de gemidos de prazer e de close-up(s) da face do segundo estuprador, os planos isolados remetem ao prazer no ato sexual sem que o relacionemos a um ato de violência. Quando em relação, o prazer da violência já não aparece mascarada como no primeiro estupro: mostra-se sem pudor aos olhos do espectador, cujo êxtase converte-se no fim da agonia de Thana.

\footnotetext{
31 Sorlin, Pierre. Sociología del Cine - La apertura para la historia de mañana. Cidade do México: Fondo de Cultura Económica, 1985, p. 53; a partir de agora, e sempre que necessário, a tradução será minha.

32 Cf. Ferro, Marc. Cine e Historia. Barcelona: Editorial Gustavo Gili, 1980, p. 58.

33 Balázs, Bela, “A face do homem”, op. cit., 1983, p. 93.
} 


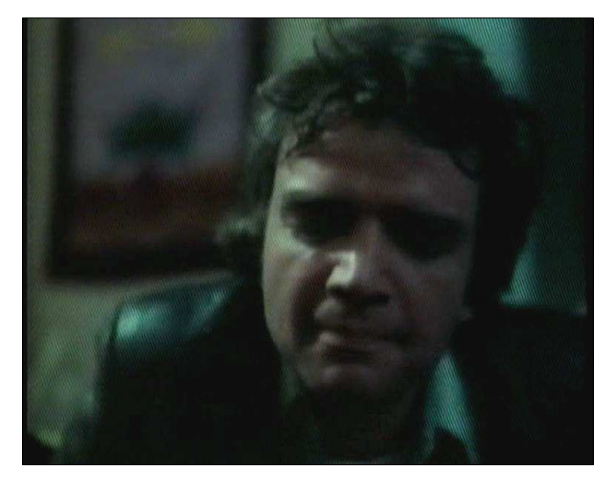

Sorlin argumenta que,

um filme não organiza apenas uma ficção; ele coloca também alguns personagens na presença de outros e instaura relações entre eles. (...) Colocando em relação indivíduos e grupos, cada filme constitui, no interior do mundo fictício da tela, hierarquias, valores, redes de intercâmbio e de influências ${ }^{34}$,

de modo que, ao se estudar o cinema, deve-se não apenas pôr em evidência os principais sistemas relacionais de uma narrativa, como estabelecer comparações entre esses sistemas quando nos debruçamos sobre um conjunto de filmes ${ }^{35}$.

Segundo Sorlin, a maioria das narrativas desenvolve-se tendo como mote situações que se constituem como um desafio ou uma carência. Não é raro, no entanto, que situações de desafio-carência se conjuguem e que, ao fim, uma delas prepondere ${ }^{36}$. É exatamente o que ocorre em Sedução e Vingança. A narrativa se desenvolve a partir de uma situação de carência (Thana não dispõe de segurança alguma - em casa ou na rua - que lhe assegure integridade física, tendo sido estuprada duas vezes no mesmo dia), para então desenvolver-se através de um desafio (a maneira como Thana conquista segurança é tornando-se uma assassina em série). O enredo mobiliza fundamentalmente dois grupos de personagens que se relacionam a Thana diferentemente. $\mathrm{O}$ primeiro agrupa seus conhecidos: seus colegas de trabalho, seu chefe, a zeladora de seu prédio e um outro jovem morador do edifício. O segundo inclui suas vítimas, todas do sexo masculino. Os dois grupos apresentam personagens que são nomeados e outros que são

34 Sorlin, Pierre, Sociología del Cine, op. cit., 1985, p. 147 e p. 202.

35 Cf. Sorlin, Pierre, op. cit., 1985, pp. 202-206.

36 Cf. Sorlin, Pierre, op. cit., 1985, p. 202. 
anônimos, favorecendo uma identificação mais ampla com papéis sociais, mais que com suas identidades pessoais.

Thana é assistente em um ateliê de costura situado no Garment Center de Manhattan. Sua posição subalterna é marcada pela maneira como é vista no ateliê. Ela aparece geralmente ao fundo da oficina de costura, passando roupas a ferro, quase como figurante. Seu chefe revela sua posição no ambiente de trabalho desde o início da narrativa: ao fechar uma venda, elogia as duas estilistas do ateliê como entre as melhores de Nova Iorque. Ao defrontar-se com Thana deixando o lugar, despede-se dela sem qualquer referência a seu trabalho, como se nada tivesse a dizer sobre ele. A posição subalterna de Thana também aparece em relação às demais funcionárias da empresa. Após um almoço que reuniu suas funcionárias mais jovens, as estilistas e Laurie, muito preocupadas com seus afazeres, deixam Thana no restaurante para esperar o troco, propondo, dessa maneira, que o que quer que fosse que ela teria a fazer de volta ao trabalho era menos importante do que as atividades das demais. Neste sentido, seu trabalho aparece como trabalho desvalorizado, mesmo estando inserido no meio da cadeia produtiva.

De modo geral, seu chefe e as demais funcionárias do ateliê são condescendentes com ela. Não a tratam com desprezo, ao contrário, mas a preocupação que demonstram é por vezes excessiva, justificada pela condição diferencial de Thana frente aos demais, oriunda de sua mudez. Quando Thana começa a mostrar-se perturbada e desinteressada pelo trabalho, Albert, seu chefe, reitera que devido à sua condição ela deveria esforçarse mais que as outras para agradar, como se a mudez pudesse de algum modo interferir com a atividade de passar roupas e pregar botões. Já uma das estilistas do ateliê chamaa para sair no primeiro dia da história, e, demonstra preocupação em relação à situação de Thana após a conversa que a protagonista tem com o chefe. Thana, no entanto, esquiva-se dela nas duas ocasiões. Recusa o convite feito pela estilista e pede para que ela a deixe em paz. Estas construções reiteram tanto a recusa de Thana em integrar-se ao grupo de funcionárias do ateliê quanto que Thana é tratada como disabled. $\mathrm{O}$ termo em inglês remete, assim, à incapacidade num sentido amplo. Se no início do filme ainda não se tem a informação de que Thana é muda, ela já é tratada como incapaz em algum sentido, e tal tratamento permanece durante toda a narrativa.

Inserida em uma atividade que é tradicionalmente exercida primordialmente por mulheres, percebe-se que no ateliê trabalham cinco mulheres e dois homens. Às mulheres correspondem as funções de concepção e realização das peças, em vários 
níveis hierárquicos relativos à produção. A produção não parece ter escala industrial, apesar da cliente que aparece no início do filme encomendar peças para todas as suas lojas, sem que se diga quantas são. Já os homens ocupam as funções mais alta e mais baixa na hierarquia. Identifica-se o personagem de Albert à função de chefe do ateliê da Harold's Incorporated, mas ele poderia ser também o dono da empresa, já que não é visto reportar-se à ninguém acima dele. $\mathrm{O}$ outro homem figura como encarregado da limpeza. Sua aparição relaciona-se ao momento em que Thana dá-se conta de como livrar-se do corpo do invasor, logo após Albert rasgar um modelo produzido pelas estilistas que não se adequava ao que ele havia solicitado. A presença do encarregado da limpeza naquele momento relativiza a posição de Albert no ateliê - desvinculando-a de uma possível dominação de gênero $^{37}$ no ambiente de trabalho.

Albert aparece como um personagem que mobiliza uma forma de comandar que é primordialmente manipuladora. Para Christopher Lasch, a sociedade norte-americana vê surgir nas últimas décadas do século passado um administrador que exerce sua influência dentro das corporações a partir de uma manipulação travestida de permissividade, cujo principal efeito está na construção de um pretenso consenso quando surgem conflitos. Assim, aqueles que são revestidos de cargos de chefia não mais dispõem de seus subalternos indiscriminadamente, mas descobrem na manipulação um modo mais sutil de mantê-los em seus lugares ${ }^{38}$. É assim que Albert recompensa o bom trabalho da semana dando a tarde de folga às funcionárias, antes da festa de Halloween, e é nesta mesma chave que elogia o trabalho das estilistas. Ao chamar atenção de Thana pela segunda vez, invoca a cooperação à corporação como se estivesse dando bronca em uma criança, cobrando-lhe a promessa de que iria comportar-se, para, então, insistir que ela lhe acompanhe na festa de Halloween. Albert, no entanto, não realiza a manipulação corporativa plenamente, uma vez que o conteúdo autoritário dessa forma de interação vem à tona quando ele perde o controle com as funcionárias.

Entre os personagens do grupo de trabalho de Thana, destaca-se também Laurie, funcionária que exerce várias funções no ateliê, entre elas a de assessorar Albert. Ela é quem parece ter mais contato com o chefe e, também, maiores responsabilidades entre

37 De acordo com Judith Butler, o gênero consiste na "repetida estilização do corpo, um conjunto de ações repetidas no interior de um conjunto de regulações altamente rígidas, que se cristalizam no tempo para produzir a aparência de uma substância, de um tipo natural de ser". Butler, Judith. Gender Trouble. Feminism and the Subversion of Identity. Nova Iorque, Londres: Routledge, 2007, p. 45.

38 Cf. Lasch, Christopher. A cultura do narcisismo. A vida americana numa era de esperanças em declínio. Rio de Janeiro: Imago, 1993, pp. 224-228. 
as funcionárias. A importância de Laurie para a narrativa não se estabelece, no entanto, no interior do ateliê. Três momentos da história marcam sua presença: no primeiro, as funcionárias recém-saídas do trabalho percorrem as ruas adjacentes ao ateliê. Elas passam por uma série de homens que as observam e as abordam. Laurie é a única a defender-se, sendo inclusive, grosseira no modo de falar. No segundo momento, no restaurante onde as mesmas funcionárias almoçam, Laurie percebe o olhar fixo de Thana sobre um casal que se beija na mesa ao lado e se incomoda com a cena. Reclama, e, quando o homem vem falar com elas, é ela quem o dispensa, também de forma nada educada. Nas duas situações, nenhuma das outras funcionárias se pronuncia; uma delas apresenta, ao contrário, um olhar divertido, sentindo-se cortejada. Em ambas as ocasiões, as garotas falam sobre homens com quem se encontraram. Laurie não parece, no entanto, dar muita importância a este tipo de conversa. Já no terceiro momento, Laurie aproveita-se que Thana não atira nela e a detém, metendo-lhe a faca do bolo da festa pelas costas. Laurie constitui-se, assim, como a dona da voz e da ação. Ela, de algum modo, contrapõe-se ao estereótipo feminino geral proposto pelo filme: o da mulher cujo único objetivo é encontrar um homem para chamar de seu, e de preferência que possa lhe oferecer algum conforto. A construção de seu personagem propõe uma jovem mais independente, mais bem sucedida e assertiva, não porque seja certinha, mas porque tem a habilidade de lidar com o mundo urbano e do trabalho. Por isso, Laurie pode dar-se ao luxo de mostrar-se leviana em alguns momentos, assim como as demais jovens que participam do enredo.

Entre os conhecidos de Thana, os últimos personagens a destacarem-se são a Sra. Nasone e seu cachorro, Phil. Ela apresenta-se fundamentalmente como uma viúva solitária que distribui seu tempo entre cuidar do cão e bisbilhotar a vida dos moradores do prédio. No entanto, ela é a única a perceber e externar as mudanças no comportamento de Thana, a ponto de invadir seu apartamento e lá encontrar a cabeça do invasor escondida no armário. A Sra. Nasone é, neste sentido, o personagem do filme que parece dar-se conta da existência da protagonista, ainda que não tenha percebido nada estranho no dia da invasão de seu apartamento. A presença dela no enredo faz com que se perceba a simplicidade do estilo de vida de uma jovem como Thana e a irrelevância de sua inserção neste contexto urbano de trabalho e de violência do qual faz parte.

A Sra. Nasone, contudo, não é caracterizada de modo a despertar a simpatia do espectador; a voz estridente, a maquiagem carregada e o exagero de seu figurino e do 
cenário de seu apartamento, contrapostos à economia minimalista que envolve os outros espaços apresentados na trama, corroboram para que a Sra. Nasone seja percebida na chave do grotesco.

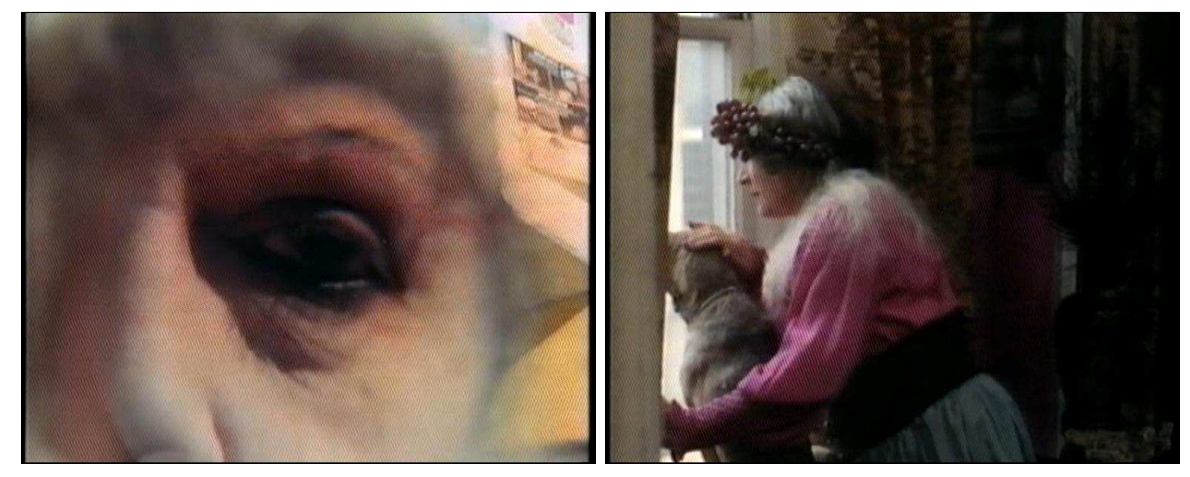

Phil, o cachorro, é a principal companhia da Sra. Nasone e o único por quem parece nutrir afeição. Sua presença na narrativa é de suma importância. Os latidos do cachorro passam, a partir de certo momento, a remeter à ameaça que a Sra. Nasone representa ao segredo de Thana. Sempre que pode, o cachorro entra no apartamento da protagonista e direciona-se aos locais onde partes do corpo do invasor estão escondidas. Thana, por sua vez, revida no cachorro as intromissões da zeladora: alimenta-o com a carne do invasor e predispõe-se a matá-lo, mas não o faz, abandonando-o pela cidade. $O$ cão retorna ao apartamento da Sra. Nasone no fim do filme, apresentando, assim, um comportamento mais frequentemente associado a um gato. Ainda que Thana opte por agir contra a ameaça que o cachorro representa abandonando-o à própria sorte pela cidade, poupar-lhe a vida a distingue do suicida que revidara no gato de sua esposa a ira por ter sido traído. Contudo, tal atitude indica também que Thana não tem como alvo outra mulher. Corroboram tal interpretação também as sequencias que mostram Thana titubeando antes de alvejar o convidado da festa de Halloween que se fantasiara de noiva e esquivando-se de defender-se de Laurie.

As relações que Thana mantém com suas vítimas são furtivas e circunstanciais. Muitas vezes Thana só precisa olhar para dar seu veredicto: culpado por ser homem! No entanto, essas situações dão conta de construir um estereótipo poderoso a respeito dos homens que integram a narrativa. Pode-se dizer que, com exceção dos figurantes, quase todos os homens que falam durante o desenvolvimento do enredo, desde aqueles que abordam as mulheres nas ruas de Nova Iorque até o chefe de Thana, remetem, em pelo menos um momento de sua participação, a um conteúdo sexual e/ou machista. Deste 
modo, a fala, que em Sedução e Vingança constitui-se na fala do outro, estabelece os pontos de tensão a serem explorados pela narrativa e apresenta-se como fundamento da indistinção apresentada pelo filme entre corte e assédio. Esta indistinção pode ser percebida pelas diferentes reações femininas mostradas pelo filme em relação à abordagem masculina, como quando o fotógrafo aborda as funcionárias do ateliê no restaurante. $\mathrm{O}$ que poderia constituir-se como corte e assédio não é problematizado na narrativa, podendo ser atribuído facilmente às disposições femininas em relação ao sexo oposto e às questões de natureza individual.

Entre as vítimas de Thana, o jovem que acredita que as mulheres estão frias por não lhe darem atenção e segue Thana pela rua merece aqui maior atenção. Considerando-se sua atitude para com a protagonista, sua morte pode parecer gratuita, principalmente quando comparada à morte do invasor. Sua justificativa na narrativa, no entanto, percorre duas direções distintas, composta pela combinação de três elementos.

O primeiro remete a um possível medo de Thana em ser descoberta. A reação violenta se justificaria, então, no sentido de que o primeiro assassinato não viesse à tona. No entanto, para isso bastaria que ela recebesse a sacola do jovem e se desfizesse dela em outro local. Não é isso que acontece. O segundo elemento emerge se considerarmos que é a atitude do jovem para com Thana que lhe aparece como ameaça. Ser seguida por um homem após os estupros, poderia, assim, ter-lhe causado pânico. É em decorrência deste elemento que a narrativa propõe, na sequência, que a corte masculina apareça como assédio; o que constitui, no meu entender, a justificativa mais significativa para o assassinato do jovem.

Este é exatamente o terceiro elemento, proposto no filme a partir do diálogo que o jovem mantém com o senhor cego ${ }^{39}$, enquanto aborda as mulheres que passam por eles na esquina, perto de onde, pouco depois, Thana desce do táxi, até o fím da sequência. A abordagem feminina nas ruas, aliás, já era um elemento presente desde o início da história, visível através da ação dos homens nas cercanias do ateliê.

Segundo Beth A. Quinn, alguns homens consideram que olhar as mulheres de cima abaixo, proferir comentários jocosos ou provocantes, acompanhados ou não de um gestual de cunho sexual $^{40}$, são atividades que lhes são comuns, especialmente se

39 Curiosamente, tal qual acontece com Thana, não se percebe imediatamente que o homem não pode ver.

40 A autora usa a expressão girl watching para designar o conjunto destas ações, de modo a aproximar-se da linguagem utilizada por alguns dos homens entrevistados durante sua pesquisa, que descreveram as ações de seus colegas de trabalho como "they watch girls". Cf. Quinn, Beth A. "Sexual Harassment 
estiverem na presença de outros homens. Tais ações, afirma Quinn, são ambíguas, estabelecem-se no limite entre diversão e ofensa, gozação e assédio. De acordo com o argumento da autora, quando caracterizadas como uma brincadeira, o conjunto dessas ações funciona como um jogo, a partir do qual, os homens podem construir relações sociais e compartilhar identidades ${ }^{41}$. Contudo, neste jogo, a mulher é desconsiderada como sujeito, sendo tratada com nenhuma ou pouca empatia, como mero objeto; neste caso, não do desejo masculino, da corte, mas sim, servindo a afirmação de uma identidade de gênero. $\mathrm{O}$ obscurecimento da subjetividade feminina, neste jogo, e uma recusa dos homens em perceber os efeitos de suas ações, fazem com que se mostrem confusos quando uma mulher reage ou reclama ${ }^{42}$. É interessante perceber que nas duas situações em que veem-se homens abordar mulheres nas ruas em Sedução e Vingança, eles são apresentados na companhia de outros homens, o que, de certa forma, faz lembrar o argumento de Quinn, mas que, sobretudo, propõe uma atitude masculina geralmente aceita como plausível em diversas sociedades, não apenas na norteamericana.

Se o breve encontro de Thana com o jovem não é suficiente para justificar seu assassinato a partir da história contada pelo filme, ainda que se considere o medo da protagonista em ser descoberta ou novamente violentada, o conjunto formado pelo jovem que joga com sua masculinidade, pelo homem que não vê e pela protagonista que não fala, transforma o espectador na única testemunha capaz de perceber a ambiguidade que é proposta na sequência entre corte e assédio. Esta ambiguidade pode realizar-se de maneira a que o assassinato do jovem apareça plenamente justificado na chave do assédio, ou de maneira a que o mesmo apareça como gratuito, antecipando uma caracterização da protagonista como uma mulher mentalmente desequilibrada. Assim, tal qual propõe Paulo Menezes, o filme

em projeção, é percebido como uma unidade de contrários que permite a construção de sentidos. Sentidos estes que estão na relação [entre cinema, real e espectador], e não no filme em si mesmo ${ }^{43}$.

and Masculinity: The Power and Meaning of 'Girl Watching'”. In: Gender and Society, Vol. 16, ํㅜ 3, 2002, p. 387.

41 Cf. Quinn, Beth A., op. cit., 2002, p. 387.

42 Cf. Quinn, Beth A., op. cit., 2002, p. 391.

43 Menezes, Paulo, "O Cinema Documental como 'Representificação': verdades e mentiras nas relações (im)possíveis entre representação, documentário, filme etnográfico, filme sociológico e conhecimento", op. cit, 2004, p. 44; grifos do autor. 
De acordo com Menezes, a especificidade da experiência cinematográfica reside nesta relação diferencial que se estabelece entre cinema, real e espectador, que se caracteriza tanto por tornar presente como por nos colocar em presença de algo,

uma forma de experimentação em relação a alguma coisa, algo que provoca reação e que exige nossa tomada de posição valorativa, relacionando-se com o trabalho de nossa memória voluntária e involuntária que o filme estimula ${ }^{44}$.

Segundo Catharine A. MacKinnon, o assédio sexual consiste numa imposição indesejada de demandas sexuais que se estabelece a partir de uma relação desigual de poder $^{45}$. Inicialmente, o assédio sexual, nos Estados Unidos, foi concebido como uma forma de discriminação com base no sexo no ambiente de trabalho e, por conseguinte, uma violação da sétima seção do Civil Rights Act de 1964, que versa sobre formas variadas de discriminação em instituições públicas e privadas com quinze ou mais funcionários ${ }^{46}$. No entanto, algumas cortes norte-americanas passaram a reconhecer $\mathrm{o}$ assédio sexual como uma forma de discriminação com base nesta lei apenas a partir de meados da década de 1970, o que foi confirmado em âmbito federal pela Suprema Corte somente em $1986^{47}$. A definição legal do que vem a ser o assédio sexual foi dada pela Equal Employment Opportunity Comission (EEOC) em 1980:

\begin{abstract}
vantagens sexuais indesejadas, solicitações de favores sexuais e outras condutas verbais e físicas de natureza sexual constituem assédio sexual quando esta conduta explícita ou implicitamente afeta o emprego de um indivíduo, interfere sobre seu desempenho no trabalho, ou cria um ambiente de trabalho intimidador, hostil ou ofensivo ${ }^{48}$.
\end{abstract}

44 Menezes, Paulo, op. cit, 2004, pp. 44-45.

45 Cf. MacKinnon, Catharine A. Sexual Harassment of Working Women. New Haven: Yale University Press, 1979, p. 1.

46 Durante a década de 1990, o assédio sexual foi reconhecido também como uma forma de discriminação por sexo em instituições de ensino, configurando-se como violação à nona seção das Educational Amendments de 1972. Cf. Encyclopedia of Everyday Law. Sexual Harassment. Disponível via URL: http://www.enotes.com/everyday-law-encyclopedia/sexual-harassment (Sexual_Harassment_325522.pdf); acessado em 07/06/2009, p. 4.

47 Cf. Encyclopedia of Everyday Law. op. cit., p. 2, e; Altman, Andrew. "Making Sense of Sexual Harassment Law". In: Philosophy and Public Affairs, Vol. 25, N 1, 1996, p. 37, nota 4.

48 The U.S. Equal Employment Opportunity Comission. Sexual Harassment. Disponível via URL: www.eeoc.gov/types/sexual_harassment.html; acessado em 13/06/2009. Em relação às formas de discriminação no local de trabalho em geral, a EEOC deixa claro que "ofensas menores, perturbações ocasionais e incidentes isolados (a não ser que extremamente sérios) não serão elevados ao nível da 
Do ponto de vista legal, torna-se central, portanto, a determinação da natureza sexual da conduta. O problema de tal determinação, contudo, não se resume aos dilemas dos juízes norte-americanos a respeito de casos específicos. Segundo Quinn, mulheres tendem a definir mais atos como assédio e a ver mais situações como coercitivas, enquanto homens reclamam que as mulheres são muito sensíveis em relação ao assunto e que, frequentemente, interpretam mal suas intenções ${ }^{49}$. Apesar dessa diferença, a autora afirma que,

quanto mais alguém é socializado de acordo com noções tradicionais acerca dos papéis sexuais, tanto mais provável que, tanto para homens quanto para mulheres, os comportamentos sejam vistos como aceitáveis ou, ao menos, como imutáveis ${ }^{50}$.

Ainda que não seja possível discutir aqui como tais diferenças são construídas, um ensaio fotográfico publicado em 1988 por Vicky Quinlin pode ajudar a compor um panorama do que, na década de 1980, estava sendo proposto como assédio sexual pelas e para as mulheres norte-americanas.

Quinlin afirma na introdução do ensaio que,

assédio sexual não é algo que tenha apenas uma definição, uma vez que pode significar coisas diferentes para mulheres diferentes. Geralmente, no entanto, sentimos que o assédio é o tipo de comportamento e intenção que nos faz sentir raiva, medo, ou mal-tratadas ${ }^{51}$.

As quatro fotografias que integram o conjunto do ensaio ilustram o texto apresentado nas legendas. Três das legendas relacionam as imagens às situações da vida cotidiana de mulheres em que se sentem constrangidas por serem tocadas sem querer, ou por serem - ou temerem ser - abordadas nas ruas. Em relação a estas situações, o

ilegalidade. Para ser ilegal, a conduta deve criar um ambiente de trabalho intimidador, hostil ou ofensivo de acordo com pessoas razoáveis". The U.S. Equal Employment Opportunity Comission. Harassment. Disponível via URL: www.eeoc.gov/types/harassment.html; acessado em 13/06/2009. Para um discussão da exigência de um padrão de racionalidade para a determinação da ilegalidade da conduta, ver: Altman, Andrew, "Making Sense of Sexual Harassment Law", op. cit., 1996, pp. 49-55.

49 Cf. Quinn, Beth A., "Sexual Harassment and Masculinity: The Power and Meaning of 'Girl Watching", op. cit., 2002, p. 386 e p. 388.

50 Quinn, Beth A., op. cit, 2002, p. 388.

51 Quinlin, Vicky. "Sexual Harassment". In: Agenda, N³, 1988, p. 40; grifos meus. 
texto faz referência a que os homens reclamam que as mulheres exageram nas suas reações ou que sentem raiva quando as mulheres não lhes dão atenção. Mesmo quando os homens não estão presentes, as mulheres temem a violência masculina. A última legenda, que acompanha a segunda foto mostrada aqui, é a única que faz referência ao assédio no mundo do trabalho, afirmando que as mulheres são mais vulneráveis ao poder de seus chefes que os homens. O ensaio termina com um quadro com dois slogans $^{52}$ que remetem ao abuso e à ridicularização da imagem da mulher pela mídia, sendo citado pela autora como o pior dos assédios ${ }^{53}$.
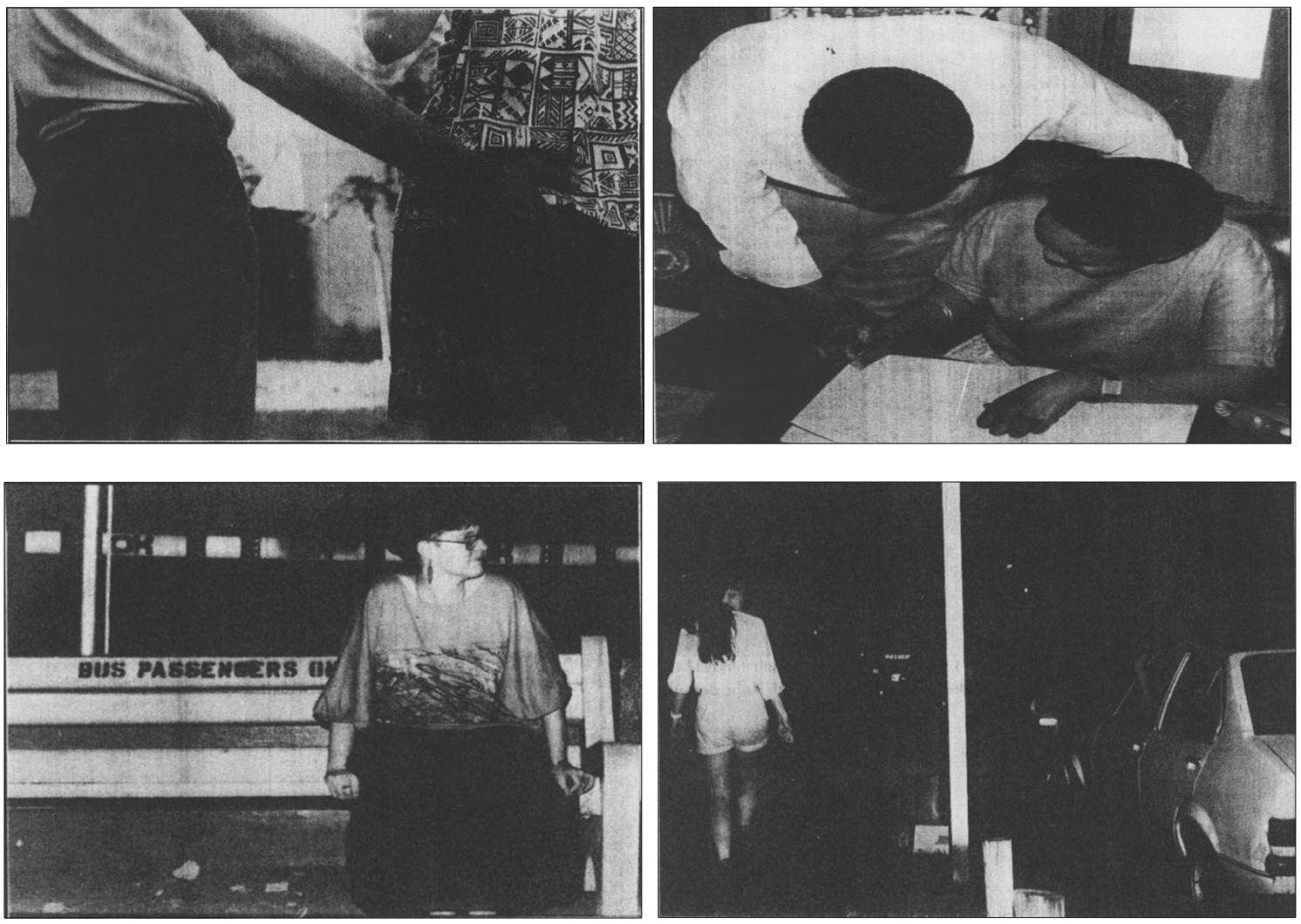

Entretanto, em nenhuma das quatro fotos apresentadas por Quinlin podem ser vistas ameaças concretas às mulheres que nelas aparecem. $\mathrm{O}$ enquadramento da primeira foto impossibilita, inclusive, identificar um possível constrangimento da mulher que é tocada. Quinlin parece ancorar-se, então, na posição da mão do homem captada pela câmera - abaixo da cintura da mulher - para estabelecer uma correlação entre a imagem e sua concepção de assédio, propondo, dessa maneira, que o toque é indesejado. Tanto nesta foto, quanto na segunda, não é possível, contudo, afirmar que o

52 A saber: "Watch my ass - not her's" e "Soldiers do it with action".

53 Cf. Quinlin, Vicky, op. cit., 1988, pp. 40-42. 
toque não seja consentido ou que desperte medo ou raiva.

Nas terceira e quarta fotos, Quinlin vale-se da ideia - bastante recorrente - que, uma mulher desacompanhada de um homem, principalmente à noite, é vulnerável. A foto da moça de bermuda que caminha pela calçada olhando na direção de um carro branco, de onde se vê um braço erguido para fora da janela, parece ser a que mais contribui para o argumento de Quinlin, por remeter ao tipo de abordagem masculina que se vê também em Sedução e Vingança. No entanto, o posicionamento do corpo da moça, na imagem, não parece ser o de alguém que se sente ameaçado.

Ao atentar para o conteúdo plástico das fotos de Quinlin, percebe-se, portanto, que nenhuma delas é capaz de construir situações de assédio. É o texto das legendas que acompanha cada uma das imagens que estabelece a relação entre o que se vê e a concepção de assédio defendida por Quinlin. Ao se debruçar sobre a fotografia jornalística, Roland Barthes afirma que, quando imagens fotográficas são acompanhadas por um texto, com frequência "o texto torna a imagem mais pesada,

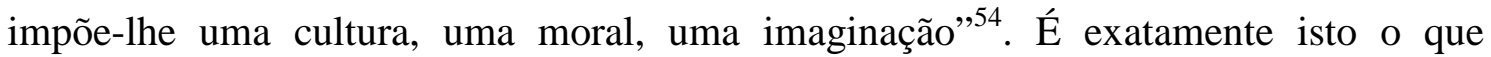
acontece com o ensaio de Quinlin. O ensaio apresenta, desta maneira, uma concepção bastante ampliada de assédio sexual e não aborda nenhuma conduta masculina que não possa ser identificada a uma violência contra a mulher, dando a impressão de que tais condutas não existem. Este tipo de discurso dialoga de forma direta com afirmações como a de MacKinnon a respeito da sexualidade: "uma construção social do poder masculino: definida por homens, imposta às mulheres, e constitutiva do significado de gênero"55. Segundo Igor Primoratz, o argumento de MacKinnon propõe uma sexualidade que

é permeada pela desigualdade de gênero e pela dominação masculina da mulher. Isso é verdade não apenas para parte, mas para todo sexo: do intercurso "normal" à prostituição, da pornografia para o assédio sexual e o estupro. (...) A presença ou ausência de consentimento marcaria de fato a diferença entre um intercurso sexual legítimo e um estupro, se as condições

54 Barthes, Roland. "A mensagem fotográfica”. In: - O óbvio e o obtuso: ensaios críticos III. Rio de Janeiro: Nova Fronteira, 1990, p. 20.

55 MacKinnon, Catharine A. Toward a Feminist Theory of the State. Cambridge, MA: Harvard University Press, 1989, p. 113. 
sociais nas quais uma mulher consente ou recusa fossem aquelas da igualdade de poder e da liberdade de escolha, mas as condições pelas quais o sexo é negociado em nossa sociedade não são essas. A extensiva desigualdade de gênero e a dominação masculina sobre as mulheres, em todas as áreas da vida social, viciam o consentimento feminino ao sexo ${ }^{56}$.

A narrativa de Sedução e Vingança, ao construir indistintamente corte e assédio, antecipa essa concepção ampliada de assédio e dominação sexual. Centralizando a análise em torno da figura de sua protagonista, a narrativa parte da abordagem do corpo feminino nas ruas até a violação. Leva a violação para dentro do ambiente doméstico, remetendo-a a um assalto ${ }^{57}$. Desloca-se novamente às ruas, onde a exploração econômica do corpo feminino, a violência física e a dominação masculina aparecem em diferentes níveis através das figuras do fotógrafo que se vale de sua profissão e prestígio para atrair belas mulheres; do cafetão que espanca a prostituta e tenta apropriar-se do dinheiro de seu trabalho; da gangue que vê numa mulher sozinha um alvo fácil; do sheik árabe que busca prostitutas como companhia ${ }^{58}$; do chefe que estranha Thana esquivar-se de seu toque; do namorado que exige livre acesso ao corpo da namorada, independente de sua vontade; do marido que desconfia da mulher porque ela já não lhe oferecia bom sexo e boa comida, a segue, descobre que ela o traía com outra mulher e mata o gato para vingar-se da esposa, dispondo-se do que lhe é caro para atingi-la. Segundo esta lógica, cada uma das vítimas escolhidas por Thana propõe uma das facetas da dominação masculina da mulher, mesmo tratando-se daquelas que ela não logra assassinar. Se, por um lado, há uma indistinção entre corte e assédio - nos casos do jovem que aborda Thana na rua, do fotógrafo e do namorado -, por outro, há uma associação entre dominação masculina e violência urbana. Dessa forma, todo comportamento masculino em relação às mulheres aparece na forma de violência e nenhuma mediação é feita no sentido de relativizar o comportamento do fotógrafo frente ao do cafetão, do estuprador frente ao do sheik árabe, de Albert frente ao do

56 Primoratz, Igor. "Sexual Morality: Is Consent Enough?". In: Ethical Theory and Moral Practice, Vol. 4, No 3, Cultivating Emotions, 2001, p. 209.

57 Parece que a tentativa de assalto faz referência não só a um contexto mais amplo de violência urbana, mas também à privação de liberdade dentro do lar, que tradicionalmente aparece como o refúgio e o domínio do corpo feminino. O conteúdo ideológico de tal afirmação não pode, contudo, ser desprezado, uma vez que o ambiente doméstico é um dos principais lugares onde se realiza a violência contra a mulher.

58 A presença do sheik é interessante, uma vez que conjuga a riqueza com a possibilidade do acesso a várias mulheres através da poligamia, praticada em muitos países árabes. 
jovem que aborda Thana na rua. Nenhum homem aparece como inocente.

$\mathrm{O}$ roteiro facilita, assim, o encontro de Thana com suas vítimas, justificando parcialmente seus assassinatos na chave do assédio sexual e da violência contra a mulher. Parcialmente porque, apesar de atribuir-lhes uma lógica dentro da narrativa, e de chamar atenção para o tratamento dispensado às mulheres em geral ${ }^{59}$, mostrando apenas o que estes homens têm de machistas, Thana aparece como louca, como uma mulher perturbadoramente desequilibrada. Segundo esta lógica, se o estupro aparece como "o mais dramático epítome da desigualdade entre homens e mulheres e da degradação e opressão das mulheres pelos homens" ${ }^{60}$, a reação de Thana constrói-se como uma reação aparentemente exagerada, levada às últimas consequências.

O conteúdo sexualizado dos personagens não é prerrogativa exclusiva dos homens que vemos em Sedução e Vingança. Homens e mulheres aparecem como pares opostos, mas não como rivais. Isto ocorreria se as mulheres aparecessem simplesmente como vítimas de abusos sexuais. No entanto, a construção da figura feminina vale-se também de uma série de estereótipos que não a tornam facilmente identificáveis como culpadas pelos abusos, mas que também não a colocam em um pedestal de pureza. Parece ser mais plausível que sejam rivais entre si na busca por um bom partido, mostrando-se quase sempre dispostas a dar atenção a certos homens - de preferência advogados e outros profissionais de status social reconhecido, como acontece com as duas estilistas do ateliê. Recusam, no entanto, a abordagem dos jovens brancos desocupados, dos negros e "latinos"61 que podem ser vistos nas ruas do Garment Center. A aparição dessas mulheres revela uma permanência no imaginário tanto da ideia de que a identidade feminina se realiza a partir da pertença a um homem, quanto que sua identidade é fundamentalmente dada por seu sexo, ideias que se relacionam, em parte a diferentes aspectos culturais, mas, também, a um extenso processo de medicalização do corpo feminino ${ }^{62}$. Tal processo é trazido à narrativa sem qualquer mediação através da

59 Na festa de Halloween, a chacina a ser cometida por Thana é justificada através de interações que mostram um dos convidados gabando-se por ter comprado virgens por trezentos dólares e um casal discutindo sobre a recusa do marido em fazer a cirurgia de vasectomia, após o nascimento do último filho.

60 Primoratz, Igor, op. cit., 2001, p. 209.

61 Cabelos negros, pele morena e lábios carnudos que insistem em pronunciar qualquer coisa em língua espanhola são geralmente os elementos estereotípicos mais associados aos "latinos" no cinema norteamericano. Ainda que se possa argumentar que o termo refira-se apenas aos latino-americanos e não aos franceses, portugueses, espanhóis e italianos, é inegável que todas as diferenças étnicas e culturais dos povos que habitam o território do continente depois da fronteira sul dos Estados Unidos desaparecem por completo nesta caracterização.

62 Para um panorama das discussões a respeito da definição da identidade feminina a partir de sua 
figura da mendiga, cuja caracterização do comportamento feminino pode ser facilmente associada às mulheres que vemos na tela. Na sequência, a mendiga que conversa com o carrinho de supermercado que empurra pela rua, indaga-se: "Não sei porque me perseguem porque não falo com mulheres. Elas só riem, cantam e falam a palavra buceta. Pergunte para qualquer médico e ele vai te contar. Eu não sei o que há de errado com essas pessoas".

Diferente das outras mulheres, Thana surge na narrativa como um personagem de uma sexualidade reprimida, não revelando nenhum desejo ou expectativa em relação ao sexo oposto. Tal caracterização serve também à pureza do personagem, marcada pela calcinha branca vista durante o primeiro estupro e uma recusa da câmera em mostrar-lhe o corpo nu. Diferentemente de outros filmes da época que constroem estupros, como Ato de vingança (Rape Squad, Bob Kelljan, 1974) e A vingança de Jennifer (I spit on your grave, Meir Zarchi, 1978), em que a câmera busca reiteradamente mostrar os corpos das mulheres violentadas expostos pelas roupas rasgadas, Sedução e Vingança mantém-se pudico em relação a exibição do corpo de Thana, preservando primeiramente sua imagem de pureza, mas também fornecendo elementos para que o personagem, enquanto uma mulher que se torna impenetrável, possa ser construído pela narrativa - uma mulher que, portanto, não pode ser desnudada, de modo a alimentar a fantasia do espectador apenas através de sua silhueta, do desenho de seu corpo revelado, embora protegido, pela roupa de couro, ou escondido pelo hábito de freira. Neste primeiro momento, contudo, sua identidade feminina é atribuída pelos outros na forma de violência. São os homens que a violam que a veem como mulher.

É possível que a mudez de Thana fosse inclusive um sintoma histérico, causado por sua sexualidade reprimida. $\mathrm{O}$ fato dela gritar antes de morrer poderia corroborar uma interpretação em tal direção: ser ferida de morte, ter como perspectiva o fim de sua agonia pelas mãos de outra mulher, viria a constituir-se, portanto, como o momento catártico de sua "redenção". Se Thana pode ser considerada histérica no sentido clínico, pouco importa. É muito mais provável que a repressão de sua sexualidade seja consequência de sua condição de deficiente. Ana Cláudia Bortolozzi Maia chama atenção para a negação social da sexualidade de pessoas com deficiência, cujo fundamento reside num imaginário que afirma que deficientes são assexuados. Segundo

genitália e da medicalização do corpo da mulher, ver: Costa, T. et al. "Naturalização e medicalização do corpo feminino: o controle social por meio da reprodução". In: Interface - Comunic., Saúde, Educ., Vol. 10, $\mathrm{N}^{\circ} 20,2006$, pp. 363-380. 
Maia, este imaginário alimenta uma socialização precária dos deficientes no que concerne ao desenvolvimento de suas sexualidades, tornando mais enfático sobre estes indivíduos o efeito da repressão sexual que compõe o processo de educação sexual geral $^{63}$.

Contudo, o pesadelo e a crise nervosa que o personagem apresenta no ateliê propõem a imagem de uma mulher perturbada que passa a assassinar os homens que encontra em seu caminho, como uma forma de lidar com o trauma causado pelos estupros que sofrera. Assim, ela realiza a promessa de seu nome, uma referência clara à Thanatos, deus grego que personifica a morte.

Esse é, talvez, o lado mais visível da moeda. Ao atentar para o significado da matança para a construção da identidade de Thana, percebe-se que, na medida em que ela encontra um sentido para sua existência no homicídio, ela também passa a apropriarse de uma imagem cada vez "mais feminina", visível através das roupas e da maquiagem. Sua identificação como mulher passa a ser resultado da apropriação da violência para si, em nada se relacionando com o mundo do trabalho ou da família ${ }^{64}$. Essa é a maior transformação em seu comportamento: tornar-se mulher perpassa a utilização dos signos que mobilizam as fantasias masculinas em torno de uma mulher provocante e sedutora; seu figurino, através do uso das calças de couro e das botas de salto alto, apenas acompanha esse direcionamento do enredo.

Em Sedução e Vingança a violência é espetáculo que aparece a partir de duas relações. A primeira remete à tríade que subjuga Prometeu: a Violência - como personagem mudo - acompanha Vulcano - o deus dos metais, e portanto, das armas e o Poder ${ }^{65}$. O poder aqui se expressa pela posse da arma: quem a detém torna-se capaz de ser expressão da violência. A posse da arma possibilita, assim, sua realização através do estupro, do assassinato e da punição - enquanto que sua perda ou ausência representa fragilidade ${ }^{66}$. A posse da arma possibilita, também, que Thana liberte-se do medo da violência masculina que compõe a lógica do assédio construída pela narrativa. Estranhamente, Thana assume sua identidade feminina ao subverter a lógica do assédio sexual - ao invés de temer, Thana passa a explorar a lógica do assédio como armadilha para suas vítimas. Daí advém a segunda relação: a dimensão fálica que se estabelece a partir da posse da arma aparece através da associação entre sexo, violência e morte.

63 Cf. Maia, Ana Cláudia Bortolozzi. Sexualidade e deficiências. São Paulo: Unesp, 2006, pp. 33-36.

64 Invisível no filme.

65 Cf. Ésquilo. Prometeu acorrentado. São Paulo: Abril Cultural, 1980.

66 Thana apenas reage ao invasor, durante o segundo estupro, quando ele deixa a arma cair. 
Thana, enquanto personagem despossuído é obrigado a deixar-se possuir. A posse da arma, ao contrário, permite que ela possua e apareça como uma mulher dominadora e impenetrável. A erotização da violência torna-se visível nas sequências em que Thana, vestida de freira, beija as balas ao carregar a arma com que realiza sua feminilidade, e em que Laurie, segurando a faca do bolo da festa como a um falo, acerta-lhe as costas.
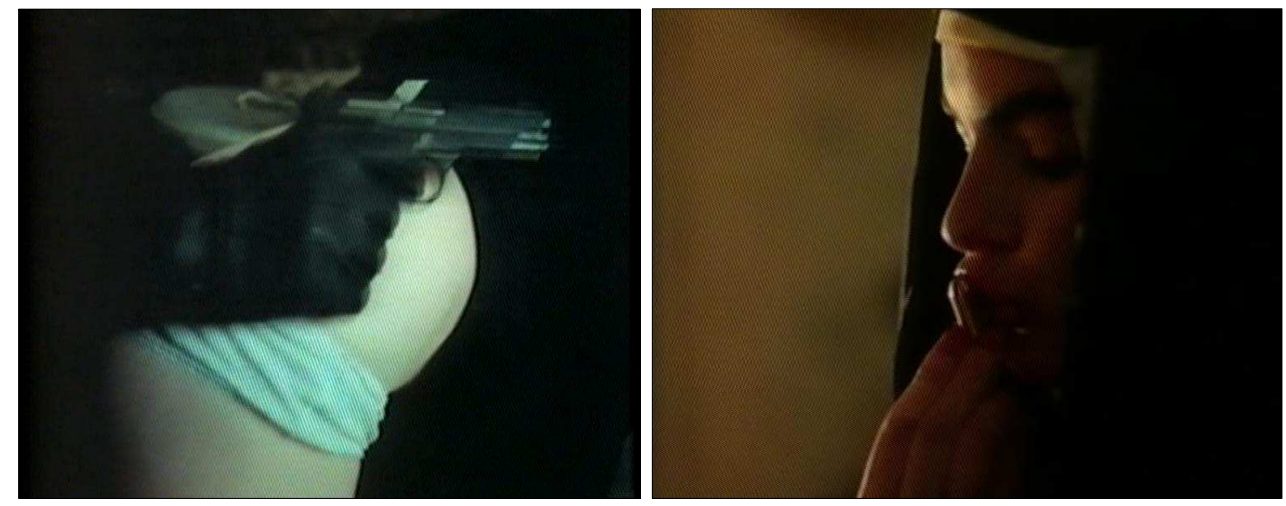

Sedução e Vingança é frequentemente citado como um filme sobre retaliação ${ }^{67}$. Mas dizer que Thana torna-se uma homicida devido aos estupros parece insuficiente. A violência que expressa ultrapassa a vingança. No caso de uma ofensa particular que demandasse uma reparação, bastaria um só estupro para que o enredo se desenvolvesse $^{68}$. Ou, mantidos os dois estupros como uma ofensa extrema, seria também bastante razoável que Thana perseguisse o primeiro estuprador e não os homens em geral $^{69}$. Sabe-se que não foram essas as opções do enredo. Minha perspectiva é de que Sedução e Vingança é um filme que se utiliza da violência como metáfora de um amplo processo de conformações do corpo feminino no mundo contemporâneo, que perpassam não apenas o sexo, mas alcançam também o mundo do trabalho. A amplitude deste processo coloca o corpo da mulher não apenas como objeto da dominação masculina, o que certamente propõe uma ilusão identitária a respeito dos sexos a partir da narrativa, mas insere-o em um contexto mais amplo de dominação e de

67 A este respeito, ver: Haskell, Molly. From Reverence to Rape - The Treatment of Women in the Movies. Chicago/Londres: University of Chicago Press, 1987, p. 373 e p. 386; Clark, Randall. At a Theater or Drive-In Near You: The History, Culture and Politics of the American Exploitation Film. Nova Iorque: Garland Pub., 1995, p. 113.

68 Como ocorre em Monster (Patty Jenkins, 2003).

69 Como acontece em A vingança de Jennifer, filme que relata a história de Jennifer Hills, aspirante a escritora que assassina os quatro homens da cidade onde decide passar o verão que a haviam estuprado. Tanto em Sedução e Vingança quanto em A vingança de Jennifer, as protagonistas usam a sedução para atrair suas vítimas. Jennifer, ao contrário de Thana, faz sexo com algumas de suas vítimas antes de matá-los. 
construção de identidades do qual todos fazem parte, homens e mulheres. A caracterização de Thana como louca expõe, de certa maneira, a diferença tratada por Quinn a respeito das percepções sobre os comportamentos de homens e mulheres. Poder-se-ia pensar que o filme toma um partido a este respeito, não só porque Thana aparece como louca, mas porque encontra sua "redenção" de maneira trágica. De forma imediata, é isso o que acontece. Mas ser morta por Laurie, contudo, complexifica esta tomada de posição. Não se trata, portanto, apenas de definir o que é corte e assédio, de demonstrar que a violência é antes de tudo um conceito moral que pode ser concebido de maneiras diferentes pelos indivíduos de diferentes sociedades e temporalidades. Ainda que um regime de dominação regule as relações entre os sexos, a presença feminina ativa na vida da cidade não transformou apenas a vida das mulheres. Se os gêneros são construídos, inicialmente, pela diferenciação de pares opostos, transformações em um desses pares implicam em transformações no outro. Trata-se, portanto, de perceber que as relações entre os gêneros não são mediadas apenas por questões de gênero, mas são permeadas por vários outros problemas que se originam da vida urbana. Se Sedução e Vingança toma um partido, é o de sexualizar as relações na cidade. O filme realiza, desta maneira, a fantasia masculina do encontro com a mulher fálica, capaz de inverter os papéis tradicionais de gênero. Para que esse encontro ocorra, no entanto, Thana deve ser construída a partir de uma distância em relação às demais mulheres da narrativa e suas ações devem ser desmedidas. Seu fim trágico apresenta-se, então, como uma reação ao desnudamento do conteúdo simbólico associado ao falo nas relações entre os gêneros, uma vez que não é a sua presença que garante as relações de dominação entre eles, mas a crença na legitimidade de sua posse ${ }^{70}$. Enquanto personificação da morte e da fantasia, Thana está fadada a perecer, realizando, assim, a associação entre morte e punição que é proposta, no enredo, por seus próprios atos.

\section{ERICA E O ESTEREÓTIPO EM TORNO DA VIOLÊNCIA FEMININA}

Passados mais de vinte e cinco anos, a temática da retaliação feminina pelas

70 Para Max Weber a dominação constitui-se na "probabilidade de encontrar obediência a um determinado mandato" e enquanto relação social pode fundar-se em vários motivos de submissão que, por si sós, não são suficientes para garantir sua provável permanência. É deste modo que, "a dominação costuma apoiar-se internamente em bases jurídicas, nas quais se funda a sua 'legitimidade', e o abalo dessa crença na legitimidade costuma acarretar consequências de grande alcance". Weber, Max. "Os três tipos puros de dominação legítima". In: Cohn, Gabriel (org.). Max Weber: Sociologia. São Paulo: Ática, 1991, p. 128; grifos do autor. 
mãos de uma vigilante parece voltar à tona em Valente.

A apresentação do filme mistura os créditos com a construção da relação entre a protagonista da narrativa e o espaço onde se desenvolve, novamente a cidade de Nova Iorque. A câmera mostra através de uma vidraça, como num grande traveling ${ }^{71}$, vários prédios enfileirados, formando uma imensa parede. Atravessa-a e mergulha para a rua, para, então, abaixar-se até o chão, onde se pode ver a protagonista captando os sons da cidade em plena Times Square ${ }^{72}$. A presença do prédio de vidro em sua arquitetura contemporânea aproxima o tempo de captura das imagens daquela do lançamento do filme, 2007, ainda que não seja possível identificar, de pronto, que tempo é esse ${ }^{73}$. Escuta-se o ruído de passos, de motores e buzinas de carros e, em off ${ }^{4}$, uma voz feminina apresentar-se: "Eu sou Erica Bain e, como você sabe, eu ando pela cidade. Eu me queixo e reclamo. Eu ando, assisto e escuto, uma testemunha de toda a beleza e feiura que está desaparecendo da nossa adorada cidade". A nostalgia de sua fala é antecipada pelo tom da música da apresentação. De acordo com Menezes, a nostalgia é uma das formas possíveis de relacionar tempo e memória ${ }^{75}$ :

71 O traveling (ou carrinho) é o "movimento de translação da câmera ao longo de uma direção determinada"; Xavier, Ismail, O discurso cinematográfico, op. cit., 2005, p. 32. Pode ser também "um deslocamento do pé da câmera, durante o qual o eixo de tomada permanece paralelo a uma mesma direção"; Aumont, Jacques [et al]. A estética do filme. Campinas: Papirus, 1995, p. 39.

72 A Times Square une a Broadway com a $7^{\mathrm{a}}$ Avenida entre as ruas 42 e 47 Oeste, na região central de Manhattan, onde localizam-se teatros e casas de espetáculos, sendo mostrada de forma recorrente em diversos filmes que se passam em Nova Iorque.

73 Outros indícios de tempo são apresentados durante o desenrolar da narrativa: o uso de aparatos tecnológicos como a câmera portátil de um dos membros da gangue que ataca Erica e David no Central Park, o iPod de Ethan, celulares, monitores de computadores de interface recente, equipamentos hospitalares e de monitoramento, além da citação a respeito do website que Erica mantém na Internet, de onde os ouvintes podem "baixar" seus programas de rádio livremente.

74 No que se refere às palavras, diálogos e comentários, Sorlin explicita que os sons podem ser in - se pronunciados por personagens visíveis na tela - ou off - quando se originam desde a parte não-visível na tela. $\mathrm{O}$ autor aponta que a relação in-off é mais complexa do que pode parecer inicialmente, uma vez que é o espectador que transforma em som in os ruídos adicionados à banda sonora, como quando ouve-se uma buzina e vê-se um engarrafamento na tela. Ainda que Sorlin considere a relação in-off insuficiente para discutir as relações entre o som e a imagem no cinema, o autor concorda que esta pode ser operacionalizada quando considera-se o ponto de vista do espectador. Cf. Sorlin, Pierre, Sociología del Cine, op.cit, 1985, pp. 53-54; especialmente nota 2, p. 54. O argumento de Sorlin parece-me, aqui, ser especialmente importante, por apontar que o som - ou a voz - off realiza-se de modos diferentes para o espectador, quando consideram-se os diálogos e os demais tipos de sons presentes em um filme, como os ruídos e a música. Talvez por isso Ismail Xavier tenha proposto uma diferenciação entre voz off e voz over ao debruçar-se sobre as funções exercidas por alguns narradores em filmes brasileiros recentes. A voz do narrador - assumindo um ponto de vista objetivo ou subjetivo em relação ao que se passa na tela - geralmente sobrepõe-se à imagem, propondo sentidos ao que se vê. Para fins de análise, considerarei a voz do narrador como sendo um som off que pode ou não assumir a função de uma voz over - ou seja, quando expressar a "'fala direta' de um sujeito" - tal qual proposta por Xavier. Xavier, Ismail. "Corrosão social, pragmatismo e ressentimento: vozes dissonantes no cinema brasileiro de resultados". In: Novos Estudos - CEBRAP, № 75, 2006, p. 139.

75 Cf. Menezes, Paulo, À meia-luz, op. cit., 2001, p. 87. 
A consciência nostálgica sonha com o lugar e o passado, sonha com seu lugar e o seu passado, não porque eles são importantes, mas porque eles são seus. (...) A nostalgia está ligada à questão da origem ou, no limite, do reconhecimento da origem como tal, colocados como referência de sua própria identidade, de sua localização no mundo e da percepção dos lugares de sua própria dor. Nesta aproximação, o tempo de então se contrapõe ao tempo de antes, que reaparece depurado de seus desastres e de suas dores. A perda definitiva é a perda ou a dissipação deste lugar ${ }^{76}$.

Assiste-se, então, a uma multiplicidade de tomadas diurnas e noturnas da cidade, de seus prédios, moradores e de Erica de costas apresentando seu programa de rádio semanal, distorcidas por vidraças e luzes de vários tipos, conectadas por uma série de fade in(s) em que a fala do personagem é montada de modo a acompanhar as rupturas espaço-temporais. Erica não explicita que fala da cidade de Nova Iorque, mas faz várias referências aos personagens, ruas e outros espaços da metrópole. Seu discurso apresenta-se como o de alguém que conhece não apenas o espaço, mas também a vida cultural da cidade, falando, portanto, de um lugar e para um público específico. Ela conta histórias de uma Nova Iorque que, segundo ela, está desaparecendo diante dos seus olhos e dos olhos daqueles que a escutam. Afirma que sua gente se foi - aqueles a quem a cidade pertenceria? Quem seriam essas pessoas? - e pergunta: "Teremos que construir uma cidade imaginária para alojar nossas memórias? Porque quando você ama algo, toda vez que um pedaço dele se vai, você perde um pedaço de si mesmo". A apresentação termina, não apenas com Erica finalizando seu programa de rádio, mas com a promessa da perda de si em uma cidade coabitada por fantasmas.

A narrativa de Valente pode ser dividida em três partes de durações desiguais. A primeira, bastante breve, relaciona Erica a David, seu noivo, e apresenta alguns outros personagens secundários da narrativa, como a chefe de Erica, Carol; sua amiga, Nicole, e; o cão do casal, Curtis. David e Erica formam um casal inter-étnico ${ }^{77}$. Apaixonados, moram em um apartamento próximo ao Central Park. Entre seus afazeres, planejam a

76 Cf. Menezes, Paulo, op. cit., 2001, p. 96.

77 Erica é caucasiana, designação que, certamente, omite suas origens étnicas por detrás da pele branca e dos olhos azuis. Bain é um sobrenome de origem celta que têm vários significados, entre eles: brancura, pureza, clareza, lealdade, e justiça; além de poder remeter também à cidade francesa de Bain. Cf. Arthur, William. An Etymological Dictionary of Family and Christian Names. Nova Iorque: Sheldon, Blakeman \& Co., 1857, p. 62. Já as feições e tom de pele de David remetem a uma possível descendência indiana ou ao estereótipo a ela associada. Seu sobrenome, Kirmani, pode ser tanto uma variação do sobrenome de origem gaélica Kerman ou Kirman, adotada por indianos durante o período de colonização inglesa da Índia, quanto remeter à província iraniana de Kerman. 
cerimônia do casamento. David parece não se interessar muito por atividades sociais: frequenta pouco os compromissos de Erica e de seus amigos e questiona a necessidade de uma cerimônia tradicional de casamento. Erica, em contrapartida, vê na cerimônia uma forma de unir-se não só a David, mas também a sua família. Ao fim do primeiro dia $^{78}$ da história narrada pelo filme, após David buscá-la em uma exposição de fotografias da cidade, decidem levar juntos o cachorro para passear no parque. $\mathrm{O}$ envolvimento dos dois como casal é reiterado na sequência que anuncia a agressão que será suporte à trama do filme: distraem-se, o cachorro é atraído por uma gangue de rua e eles são espancados ao tentarem recuperá-lo. Levados ao hospital, David morre em consequência dos ferimentos, Erica fica em coma por 3 semanas e o cão desaparece.

$\mathrm{Na}$ segunda parte do filme, Erica acorda do coma, recebe a notícia da morte de David e restabelece-se até voltar ao apartamento dos dois. Em seu luto, Erica isola-se e tem medo de sair de casa. Enquanto isso, tenta dedicar-se aos seus programas de rádio. É nesta parte do filme que os detetives Mercer e Vitale são introduzidos ao enredo, bem como Murrow, personagem investigado pelos detetives e cujo assassinato será fundamental para que Mercer relacione os crimes do vigilante ao personagem de Erica.

A terceira e maior parte do filme, relata os acontecimentos dos nove últimos dias do enredo. Erica consegue sair de casa e vai até a delegacia, mas não consegue ser atendida. Sentindo-se insegura, compra uma arma ilegal. De posse dela, volta a capturar sons pela cidade. Como que para corroborar sua sensação de que não sobreviveria um dia mais sem ter como se defender na cidade na qual agora se sente desprotegida, Erica testemunha um crime passional em uma loja de conveniência e, ameaçada pelo assassino, comete seu primeiro homicídio e foge.

Erica convence, então, Carol a deixá-la voltar ao trabalho. A partir daí seus programas ganham um tom confessional, ao discutirem a mudança da relação de Erica com a cidade e a violência urbana. Erica vai visitar a sepultura de David e, ao voltar de metrô, mata outros dois jovens. Esses assassinatos tornam evidente a crise identitária pela qual passa o personagem: Erica estranha-se, questiona-se e tenta retomar o controle sobre si mesma. Encontra Mercer após o assassinato dos jovens, e com ele estabelece uma relação repleta de ambiguidades. Insone, Erica perambula pela cidade à noite. Tendo decidido usar a arma apenas para livrar-se de situações de perigo potencial, acaba por cometer o quarto assassinato ao resgatar Chloe, uma jovem prostituta de origem

78 A data do início da história é apresentada quando Erica vai buscar informações sobre o caso, na delegacia de polícia, como sendo 11 de junho. 
"latina", de dentro do carro de um homem. Fica evidente, portanto, que não há controle possível; ela tentar poupar a vida de alguém não encerra o ciclo de violência na cidade. No entanto, é através do resgate de Chloe que Erica efetivamente converte-se em vigilante: percebe, expõe-se ao perigo e interfere, tomando a justiça para si.

A essa altura, a polícia divulga que os quatro homicídios foram cometidos pelo mesmo assassino. A mídia explora a figura do vigilante e Carol pede a Erica que abra seu programa para a opinião dos ouvintes. Também em Sedução e Vingança a mídia exerce o papel de associar os crimes cometidos por sua protagonista com a justiça feita pelas próprias mãos ${ }^{79}$, mas em Valente, devido à inserção profissional de Erica, a discussão em torno da figura do vigilante aparece com maior evidência. Após perder o controle durante o programa, Erica tenta entregar-se à polícia, que não lhe dá ouvidos. Erica, então, mata Murrow. Mercer, que investigara Murrow por três anos, começa a relacionar as pistas dos assassinatos à figura de Erica. Ela decide parar de matar, mas o aparecimento de um dos membros da gangue do Central Park a motiva a caçá-los e matá-los. Mercer a encobre em sua vingança, ela recupera o cachorro e com ele termina atravessando o túnel onde fora atacada no Central Park.

A estrutura da narrativa de Valente é relativamente linear. Num certo sentido, o tempo do filme estrutura-se como o tempo da nostalgia, de uma (re)elaboração do presente e do passado que se misturam, por vezes, na tela, a partir de flashbacks ${ }^{80}$ que propõem, de maneiras variadas, a presença de lembranças. No entanto, o primeiro flashback constrói também uma metáfora visual que marca a morte de David, através da montagem paralela de planos dos corpos desfigurados de Erica e David sendo socorridos após o espancamento, e planos do casal durante uma relação sexual. Enquanto o corpo dela aparece mais nos planos em que está com David, que a beija e a acaricia, é o corpo dele que é mais evidenciado nos planos hospitalares. A beleza das cenas em que o casal aparece acariciando-se e beijando-se intensifica a sensação de terror causada pela desfiguração de seus corpos, cobertos de sangue, feridas e hematomas. A invasão dos planos da relação sexual na dimensão espaço-temporal do hospital pode ser interpretada como um delírio de Erica, mas também como um reforço de sentido para o que fora destruído pela agressão, conferindo-lhe maior dramaticidade

79 Visível através do jornal que Laurie lê no ateliê de costura.

80 Segundo Rudolf Arnheim, "em qualquer sequência cinematográfica, as cenas ligam-se umas às outras pela ordem do tempo". Arnheim, Rudolf, A arte do cinema, op. cit., s/d, p. 27. Os desvios, como flashbacks, sonhos e recordações, constituir-se-iam, neste sentido, como rupturas temporais. Diferente do que acontece em Sedução e Vingança, em relação ao sonho de Thana, a inserção de flashbacks em Valente corrobora o argumento de Arnheim. 
e sugerindo que a relação dos dois pertence a partir de então à memória. A proposição de que Erica delira ou de que, alguma forma, sente-se tocada naquele momento, confere-lhe vida interior em sua inconsciência. A mesma sorte não é dada a David, mergulhado na inércia. A melodia da música nesta sequência lembra a da apresentação do filme, impregnada, neste momento, por um tom triste. Uma dissolução encerra a sequência e a música que a acompanha, deslocando o tempo do atendimento na emergência do hospital para o período de $\operatorname{coma}^{81}$ e convalescença de Erica em que Mercer, Vitale e Murrow são introduzidos ao enredo.

Outras sequências que remetem à vida do casal voltam a aparecer na forma de flashback quando Erica retorna a seu apartamento, após o período em que esteve internada. Ao ver Erica ligar o rádio sobre o criado-mudo ainda com o anel que lhe fora roubado no dedo, o espectador é transportado a um passado em que David e Erica ainda estavam juntos pelo toque de suas mãos e de seus corpos que se unem numa dança, para ser, então, interrompido pelo momento em que Erica é arremessada contra a parede do túnel do Central Park e perde os sentidos. A seguir, a câmera aproxima-se de Erica deitada na cama, imóvel e com o olhar perdido, para, novamente, transportar o espectador a um tempo em que Erica observa, deliciada, David tocar violão sobre a mesma cama. O luto de Erica é proposto, portanto, pelo paralelismo de planos que ora a mostram paralisada em seu apartamento, fitando o vazio, ora a visão de uma ou outra lembrança de David a seu lado ${ }^{82}$. Uma presença do ausente que mescla os tempos passado e presente da narrativa como uma assombração.

81 Ao despertar no leito do hospital, mas ainda com os olhos fechados, Erica leva as mãos aos lábios, como se ainda sentisse os de David sobre os seus.

82 O trecho da canção Answer, de Sarah McLachlan, transcritos a seguir, acompanha a sequência, que termina quando Erica é vista saindo do apartamento pelo primeira vez desde que deixara o hospital: I will be the answer / At the end of the line / I will be there for you / While you take the time / In the burning of uncertainty / I will be your solid ground / I will hold the balance / If you can't look down / If it takes my whole life / I won't break, I won't bend / It will all be worth it / Worth it in the end / Cause I can only tell you what I know / That I need you in my life / When the stars have all gone out / You'll still be burning so bright. A canção antecipa, neste momento, que a punição será realizada pelo personagem, quando declara que será a resposta no fim do caminho, mantendo-se forte, mesmo que a empreitada dure toda sua vida. A canção sugere também a manutenção do vínculo emocional entre Erica e David, apesar de sua morte. A canção volta a ser utilizada na sequência final da narrativa, incluindo a parte omitida da primeira vez, que diz: Cast me gently / Into morning / For the night has been unkind / Take me to a / Place so holy / That I can wash this from my mind / The memory of choosing not to fight. A voz de Sarah McLachlan é diminuída no último verso - que poderia remeter a uma culpa por não ter reagido durante o espancamento -, cedendo o lugar para a voz de Erica, que em off, afirma que não há retorno possível, admitindo como sua aquela identidade que lhe parecia antes estranha. A música ganha novamente destaque, de modo a que o espectador ouça o fim do trecho utilizado na primeira sequência, que diz que tudo valerá a pena no final, até o trecho que a voz solicita ser levada gentilmente a uma manhã, já que a noite foi tão cruel. O conjunto formado pela canção, pelo diálogo e pelas imagens constroi, desta maneira, o fim da empreitada de Erica. 
Na última parte da narrativa, David volta a aparecer no apartamento quando Erica recebe os convites encomendados para o casamento. Erica, neste momento, vincula a memória do casamento não-realizado não à figura de David, mas à definição das cores dos convites. Nesta sequência, no entanto, o que seria a mão de David aparece tocando mais uma vez o violão, enquanto Erica afirma que já chega - de matar ou do luto? -, perguntando, retoricamente, se ele a escuta. A sequência propõe, mais do que as anteriores, uma confusão entre os tempos, pela inserção do passado no tempo presente da narrativa. Não há, neste momento, qualquer ruptura que pudesse indicar que a visão de David é uma lembrança, tendo assumido plenamente a característica de fantasma. Algum tempo depois, ao almoçar com Mercer, Erica confessa que já não pode se lembrar bem de como eram as suas mãos.

Há uma diferença significativa entre estes momentos da narrativa. Do hospital ao regresso ao apartamento, os flashbacks em que David aparece propõem a vida em casal através de momentos de intimidade e carinho. Neles, a sexualidade de Erica aparece e realiza-se fundamentalmente através do toque das mãos e da boca de David. Como fantasma, Erica mal consegue lembrar-se de suas mãos, uma desconexão clara com seu toque e, em certa medida, com sua própria sexualidade, tal qual construída pela narrativa.

Há outras sequências em que são utilizados flashbacks. Nelas há um certo didatismo que remete aos crimes cometidos por Erica, em que são introduzidos, em geral, planos curtos dos assassinatos ou dos motivos que a levaram a cometê-los. É também, desta maneira, que vemos Ethan lembrar-se da figura de Erica no vagão de trem. Nesta sequência, no entanto, são utilizados três planos curtos de Erica no vagão, nenhum deles apresentando um ponto de vista que poderia ser o do rapaz. Quando os flashbacks constituem-se como lembranças de Erica, eles de certa forma assumem um tom de assombro, como se aparecessem de repente em sua mente, independente de sua vontade.

Dissoluções são utilizadas para sugerir uma passagem maior de tempo, como ocorre quando Erica retorna do coma no hospital e o momento em que chama a enfermeira. O fade in é uma estratégia menos utilizada, ainda que seja o principal recurso da apresentação do filme. No caso, mais que propor uma curta passagem de tempo, o uso de fade in(s) condensa informações importantes para o desenvolvimento da narrativa, relacionando-as à interioridade de Erica - uma estratégia que será abandonada em seu decorrer. Assim, os flashbacks não são marcados por fade in(s), mas 
pela montagem de planos curtos, de modo a estabelecer as rupturas da dimensão espaço-temporal.

Apesar dessas rupturas, o enredo não deixa de apresentar uma relativa linearidade no que se refere aos conteúdos. É essa relativa linearidade que confere inteligibilidade à história narrada, amarrando os acontecimentos consecutivamente em uma linha temporal mais ampla. Apesar disso, não é possível dizer exatamente em quanto tempo se passa o enredo, uma vez que a narrativa fornece informações desencontradas a este respeito. Sabe-se que David e Erica são atacados num dia 11 de junho, e que ela permanece em coma por três semanas. Entre acordar do coma e sair do hospital, os ferimentos do rosto de Erica desaparecem quase que completamente, restando-lhe apenas uma cicatriz na testa, que ela esconde com a franja do cabelo. Portanto, poder-se-ia supor que ela ainda tenha permanecido no hospital por algum tempo depois de acordar. Quando ela volta ao apartamento do casal, um de seus braços ainda apresenta um extenso hematoma. A partir daí ela se isola por um período que não parece ser muito longo, mas quando volta às ruas o hematoma do braço também já desaparecera. É muito provável, no entanto, que a presença e a ausência dos hematomas não se relacionem apenas à passagem de um tempo cronológico da história narrada pelo filme. De volta ao apartamento do casal, a sua presença reforça o sentido da agressão, passando a ser desnecessária a partir do momento que se constrói o luto do personagem - de modo que já não são os ferimentos que estão em questão, mas sim a dor da ausência de David. Quando a terceira parte do filme se inicia, torna-se mais fácil perceber a passagem dos dias. Períodos diurnos e noturnos são propostos por diferentes intensidades de luz. Além disso, a passagem dos dias pode também ser percebida através das mudanças de figurino dos personagens em ação, pela atuação da polícia e da imprensa e pela frequência dos assassinatos cometidos por Erica, que mata, ao fim, oito homens em nove dias. $\mathrm{O}$ desencontro de informações a respeito de em quanto tempo se passa o enredo dá-se a partir de Mercer: quando pergunta a Vitale se ele se recorda do caso de Erica e de David, ele afirma que o espancamento acontecera dois meses antes, mas quando pede a Mortell que rastreie a chamada que Erica fizera a ele no dia do assassinato de Murrow, ele fornece a data de 20 de julho como se fora dois dias antes.

Vários aspectos da cidade de Nova Iorque compõem o recorte espacial onde se desenrola a narrativa. Considerando, em primeiro, lugar o que aparece da cidade durante o dia, vê-se uma Nova Iorque em que se avizinham espaços de pequena e grande circulação de pessoas, com estações de metrô ao alcance de uma caminhada, trens 
passando sobre viadutos e ruas, ora vazias, ora com tráfego intenso e suscetíveis a engarrafamentos.

A narrativa circula por diferentes cenários urbanos, construindo especificidades de sua ocupação: a cidade, neste sentido, aparece segmentada e multifacetada. A utilização de cenários, onde certas atividades comerciais teriam se estabelecido, corroboram essa caracterização da cidade. Assim, Chinatown aparece como um bairro onde o comércio de rua insere uma tradicional loja de armas em meio a mercados de comida oriental. O vendedor de armas ilegais vai da rua à parte de trás de um desses mercados, contrapondo uma imagem exterior do bairro, de fachada, e uma interior, de acesso restrito. O Spanish Harlem aparece como o bairro onde se concentram lojas de penhores, de joias e de artigos de segunda mão, onde o dinheiro compra informação facilmente. A presença de figurantes vestidos com jalecos e uniformes policiais colaboram na composição dos espaços próximos ao Wynnward Hospital em Washington Heights e no interior das delegacias de polícia ${ }^{83}$. Trabalhadores da construção civil também podem ser vistos, corroborando a proposição inicial de que Nova Iorque é uma cidade cujo espaço está sob constante intervenção. Há espaços de lazer ao ar livre espalhados pela cidade, como quadras de esportes e jardins, geralmente ocupados por jovens $^{84}$.

É através dessa diversidade de cenários que a complexidade da vida metropolitana é proposta em Valente. As frequentes referências aos nomes de lugares reais e imaginados, como o Central Park e o Wynnward Hospital, imprimem legitimidade a essa proposição da cidade. No entanto, a relação entre este tipo de informação naturalista e a narrativa é um tanto mais complexa que na maioria dos filmes que usam esse tipo de estratégia: uma vez que Erica é aquela que caminha pela cidade, a construção de Nova Iorque requer essa abrangência. Seria paradoxal se ela fosse vista perambular sempre e, apenas, pelos mesmos cenários. Neste sentido, ela e o espectador que a acompanha precisam ver Nova Iorque como uma metrópole, cujo sentido é proposto, portanto, a partir da diversidade de cenários e da segmentação de sua ocupação.

83 No entanto, não são vistos policiais andando pelas ruas ou em patrulha pela cidade, a não ser no caso de ocorrências.

84 Não é incomum que estas sequências sejam acompanhadas por um trilha sonora diferenciada, em que são utilizados ritmos eletrônicos ou hip hop. Nomes de bandas como Radiohead e Wu-Tang associamse a diferentes classes e inserções sociais. Assim, o iPod encontrado com o jovem negro morto por Erica no metrô não pode ser dele porque armazena músicas de bandas como Radiohead, U2 e Dixie Chicks. 
À noite, a circulação pela cidade diminui. É na proposição da Nova Iorque noturna que se tornam mais evidentes a adequação dos cenários à geografia das ações de Erica, que ora perambula por espaços vazios, ora se depara com outros habitantes da cidade andando pelas ruas. Assim, quando se faz necessário que ela se torne mais uma na multidão urbana, basta que ela vire uma esquina para misturar-se aos transeuntes. Quando, ao contrário, a ação requer a ausência de testemunhas, todos desaparecem como que por um passe de mágica. É isso que acontece quando Erica e David são agredidos no Central Park. Antes de entrarem no túnel, veem-se outras pessoas no parque. Depois que entram, ninguém mais aparece. Da mesma forma, após matar os dois jovens no metrô, Erica deixa a estação sem cruzar com ninguém saindo dos vagões ou chegando à estação, sai à rua e encontra um bar cheio de gente, passa tempo suficiente no banheiro do bar para vomitar, arrumar-se e se estranhar em frente ao espelho sem que ninguém a perturbasse ou desse conta de sua presença.

Erica mora perto de uma das entradas do Central Park e de uma estação de metrô. Em sua rua veem-se outros prédios residenciais e, geralmente, há poucos transeuntes. A proximidade com o Strangers' Gate do Central Park informa, ao espectador que tem algum conhecimento da geografia da cidade, que Erica vive em uns dos bairros nobres a oeste do Central Park. Em seu apartamento, são vistos objetos e móveis de estilo contemporâneo, cuja disposição no cenário remete a um uso funcional do espaço. De acordo com Georg Simmel, as relações espaciais são condição e símbolo de relações humanas ${ }^{85}$. Deste modo, a ocupação do prédio de Erica também informa a respeito das relações sociais na cidade: no início da narrativa, o prédio abriga o casal inter-étnico - Erica e David - e uma vizinha negra, propondo um contraponto importante à segmentação no resto da cidade, contraponto este que será reforçado pela inserção do detetive Mercer à narrativa - também negro. Em Valente, diferentes etnias de uma mesma classe convivem harmonicamente. Dessa maneira, a segmentação sócioespacial que compõe o retrato da cidade é amenizada, deixando de parecer associada, num plano geral, à origem étnica, mas sim a sua posição de classe. É dessa maneira que a delinquência e a marginalidade ligam-se, em primeiro lugar, às classes baixas. Os "latinos", sem dúvida, destacam-se nesta equação, mas não são os únicos. A tensão surge, então, da circulação dessas pessoas pela metrópole e, a violência urbana, do choque entre diferentes classes. A narrativa seria monotônica neste sentido se Mercer

85 Cf. Simmel, Georg. “O estrangeiro”. In: Moraes Filho, Evaristo (org.). Georg Simmel: Sociologia. São Paulo: Ática, 1983b, p. 182. 
não apresentasse a Erica a figura de Murrow, homem branco e de classe alta que faz uso de sua posição e status para manipular a lei. Erica aparece, portanto, entre uma e outra posição. Ainda assim, são os "latinos" que aparecem como os que ocupam os espaços mais deteriorados e relacionados à criminalidade.

Além do apartamento de Erica, outros cenários internos aparecem no filme, destacando-se entre eles, a estação de rádio onde trabalha Erica, duas delegacias e a central de polícia. Neles há, geralmente, pouca economia de objetos, mobiliário e aparatos. Diferentes tonalidades de cores e materiais ajudam a compor os ambientes. Assim, tons de madeira destacam-se na estação de rádio, gradações de azul e metal marcam as divisórias e portas de delegacias e da central de polícia. Transporte, comércio, vida cultural contrapõem tons quentes e frios, de modo a caracterizar a metrópole de Nova Iorque a partir desses cenários urbanos internos e externos, em que se mesclam limpeza e sujeira, sofisticação e frugalidade, legalidade e criminalidade.

Não é à toa que Erica vive nas cercanias do Strangers' Gate do Central Park. O termo stranger possui, na língua inglesa, dois significados primordiais: estrangeiro - no seu sentido arcaico - e estranho. Para Simmel, o estrangeiro é o viajante potencial, aquele que nem partiu, nem superou a liberdade de ir e vir. Ao fixar-se como membro de um grupo espacial, sua posição é marcada por ele não ter pertencido ao grupo desde o começo e por ter-lhe introduzido qualidades que não se originaram em seu interior. Dessa forma, o estrangeiro situa-se também fora do grupo, podendo confrontá-lo. No seu sentido positivo, o fenômeno do estrangeiro pode realizar, assim, a síntese de proximidade e distância que ocorre em toda relação humana, a partir de formas específicas de coordenação e interação ${ }^{86}$. Deste modo,

o estrangeiro está próximo na medida em que sentimos traços comuns de natureza social, nacional, ocupacional, ou genericamente humana, entre ele e nós. Está distante na medida em que estes traços comuns se estendem para além dele ou para além de nós, e nos ligam apenas porque ligam muitíssimas pessoas $^{87}$.

No entanto, há, segundo Simmel, "uma forma de 'ser estrangeiro' que rejeita até mesmo aquilo que se tem em comum, com base em algo mais geral que abrange ambas

86 Cf. Simmel, Georg. op. cit, 1983b, pp. 182-183.
87 Simmel, Georg. op. cit., 1983b, p. 186. 
as partes" ${ }^{\prime 88}$. Neste caso, a relação com o estrangeiro perde seu sentido positivo, tornando-se uma não-relação:

antes, enquanto membro do grupo, ele está ao mesmo tempo próximo e distante, como é característico das relações fundadas apenas naquilo que é genericamente comum aos homens. Mas entre os dois elementos produz-se uma tensão particular entre a proximidade e a distância, quando a consciência de só ser comum o absolutamente geral faz com que se acentue especialmente o não-comum. No caso de uma pessoa estranha ao país, à cidade, à raça, etc., este elemento não-comum, todavia, mais uma vez, não tem nada de individual, é meramente a condição de origem, que é ou poderia ser comum a muitos estrangeiros. Por essa razão, os estrangeiros não são realmente concebidos como indivíduos, mas como estranhos de um tipo particular: o elemento de distância não é menos geral em relação a eles que o elemento de proximidade ${ }^{89}$.

Ao tornar-se vítima da violência na "metrópole mais segura do mundo", Erica torna-se estrangeira em seu próprio espaço, ao mesmo tempo em que a cidade torna-se estranha a ela. Para Sigmund Freud, existe uma dimensão amedrontadora no estranho, que se caracteriza não por ser algo desconhecido ou novo, mas sim por ser algo que foi familiar em algum estágio anterior da mente e que retorna no tempo presente. Há também, dessa maneira, uma relação de distanciamento e proximidade na noção de estranho cunhada por Freud, no sentido em que, a sensação de estranheza frente a algo ou alguém - que pode ser o próprio indivíduo que sente - é um sinal do retorno do reprimido ou do superado, do familiar que se apresenta como não-familiar ${ }^{90}$. No caso de Erica, o que retorna é a violência. Entre os fatores que transformam algo assustador em estranho, interessa, em primeiro lugar, o que o autor chama de onipotência dos pensamentos, que se funda na capacidade humana da auto-observação. O que se conhece como "consciência" constitui-se, assim, como uma atividade especial, cujas funções são a observação, a crítica e até mesmo a censura do eu, que é tratado como objeto de si mesmo, como um duplo ${ }^{91}$. "Quando tudo está dito e feito, a qualidade de

88 Simmel, Georg. op. cit., 1983b, p. 187.

89 Simmel, Georg. op. cit., 1983b, p. 187; grifos meus.

90 Cf. Freud, Sigmund. "O 'estranho"'. In. __. Obras Psicológicas Completas de Sigmund Freud: Edição Standard Brasileira. Volume XVII. Rio de Janeiro: Imago, 1969, p. 275 e p. 310.

91 Cf. Freud, Sigmund, op. cit., 1969, p. 294. O termo consciência aparece problematizado pelas aspas 
estranheza só pode advir do fato de o 'duplo' ser uma criação que data de um estádio mental muito primitivo, há muito superado - incidentalmente, um estádio em que o o 'duplo' tinha um aspecto mais amistoso"92. É a partir do choque com esse duplo mais amistoso, anterior e não-violento, que Erica estranha a cidade e a si mesma. Em seu primeiro programa de rádio após o ataque, Erica confessa com um tom de voz sombrio:

Nova Iorque, a metrópole mais segura do mundo... Mas é horrível temer o lugar que um dia você amou. Ver uma esquina que você conhecia tão bem e ter medo da sua sombra. Ver degraus familiares e ser incapaz de subir-los. Nunca entendi como as pessoas podiam viver com medo. Mulheres com medo de ir para casa sozinhas, pessoas com medo de pó branco nas suas caixas de correio, da escuridão e da noite. Pessoas com medo de pessoas. Sempre achei que o medo pertencia a outras pessoas. Pessoas mais fracas. $\mathrm{O}$ medo nunca me tocava. E então, ele tocou. E quando ele o faz, você descobre que ele estava lá o tempo todo, esperando, sob a superfície de tudo aquilo que você amava. E você sente a pele formigando, seu coração adoece e você olha para a pessoa que um dia você foi, descendo aquela rua, e se pergunta se um dia você voltará a sê-la ${ }^{93}$.

No trecho acima, Erica elenca alguns elementos que constroem o medo da violência na cidade. $\mathrm{O}$ primeiro deles remete à vulnerabilidade associada à figura da mulher desacompanhada, facilmente identificada a um contexto de violência urbana, tal como é explorado em Sedução e Vingança. O segundo elemento refere-se ao pânico originado pelas cartas enviadas a alguns meios de comunicação de massa e parlamentares dos Estados Unidos, após os acontecimentos de 11 de setembro de 2001, que continham um pó branco que serviu de veículo para a bactéria Bacillus anthracis, causadora da infecção aguda denominada Antraz. Na época, a contaminação pela bactéria causou a morte de cinco pessoas, um número irrisório frente aos quase três mil mortos em decorrência do colapso das Torres Gêmeas. A referência às cartas com Antraz é, sem dúvida, uma referência aos acontecimentos de $2001^{94}$, uma referência "tímida", mas que dá conta de propor um perigo que se esconde por traz do banal - uma

no original.

92 Freud, Sigmund, op. cit., 1969, p. 295.

93 Pergunta que responderá, negativamente, na sequência final do filme.

94 Assim como também o é a data do ataque sofrido por Erica e David no parque, apesar deste ocorrer em um mês diferente daquele dos acontecimentos daquele ano. 
carta, um avião sobrevoando uma metrópole, um passeio no parque - e que pode, quando concretizado, assumir uma dimensão espetacular - ao ser transmitido repetidamente em canais de televisão do mundo todo ou ao ser gravado pelos agressores como um filme de Hollywood.

Apresentando-se como um personagem que mantém uma profunda relação com a cidade de Nova Iorque, poder-se-ia esperar que Erica fizesse alguma menção à ausência dos edifícios do World Trade Center na paisagem da cidade, mas não é isso o que acontece. Opta-se, ao contrário, em incorporar o "terrorismo" como um elemento amedrontador da vida na cidade e que expande os limites da violência urbana, tal qual construída pela narrativa. A gente de Nova Iorque que se foi - a qual Erica se refere na apresentação do filme e da qual naquele momento se distinguia - é aquela tocada por esse tipo de violência. Uma violência que faz com que a cidade que lhes era familiar apareça, subitamente, como aterradora. Dessa maneira, Valente apresenta-se como um filme que aborda a violência urbana de uma Nova Iorque pós-11 de setembro e as transformações nas relações com a cidade daqueles que tinham sua identidade em parte ancorada na imponência das torres que ruíram. Os sentimentos que a figura do vigilante é capaz de despertar - a celebração, o horror, o prazer, o desejo e a frustração ${ }^{95}$ - põem em evidência os aspectos emocionais desta empreitada.

A entrada do parque simboliza, assim, o processo de estranhamento de Erica consigo mesma e com a cidade e as transformações pelas quais passa o personagem durante a narrativa. O espaço que o personagem ocupa é, portanto, o espaço do estrangeiro e do estranho, daquele que é distante e irreconhecível. Isto acontece, inclusive, em relação aos outros criminosos que aparecem na narrativa, uma vez que Erica é construída de uma maneira diferente dos demais: além de ocupar uma posição social média entre eles, todos homens, seu personagem contrapõe-se ao estereótipo que a narrativa constrói sobre a violência, em geral, e sobre a violência feminina, em particular.

A narrativa se desenvolve a partir de dois pontos de referência que se entrelaçam através de um constante paralelismo entre blocos de ação. O primeiro e central, gira em torno de Erica. O segundo se organiza em torno da figura de Mercer. O paralelismo entre os pontos de referência estabelece-se desde a segunda parte do filme e permanece até o fim da narrativa, intercalando blocos de ação que propõem a ocorrência de

95 Que aparecem através das opiniões dos ouvintes de Erica. 
acontecimentos concomitantes e que reiteram a conexão entre os dois personagens.

A montagem se organiza a partir de planos de durações variadas. Planos curtos dão maior ritmo à narrativa, mas também são usados, com frequência, planos de média e longa duração, principalmente quando a ação se desenvolve em torno da figura de Erica. Neste caso, não é incomum que a câmera seja posicionada em lugares pouco habituais, como por detrás de prateleiras, grades de portão e outros obstáculos visuais. O ponto de vista apresentado dá a impressão de que a câmera testemunha e acompanha os passos de Erica e, neste sentido, exploram-se planos mais longos, concebidos como travelings em que a câmera se movimenta em várias direções, aproximando-se e afastando-se de modo a apresentar diferentes recortes de seu objeto. $\mathrm{O}$ deslocamento da geografia da ação e do interesse dramático é, assim, realizado também pelo próprio movimento de câmera.

Quando a ação volta-se à Mercer, a estratégia de filmagem muda consideravelmente: há maior frontalidade da ação em relação à câmera, os planos geralmente são mais curtos e sua montagem mais segmentada.

Em Valente a montagem sonora tem na voz um aspecto fundamental, desempenhando um papel central na narrativa. A voz aparece na chave proposta por Ismail Xavier, como via de “expressão da 'fala direta' de um sujeito (...), que se apresenta como voz over, sobrepondo-se à imagem para narrar parte da história, fazer comentários e antecipar sentidos" 96 , propondo, dessa maneira, a exposição de sua memória e sua biografia. Ainda segundo Xavier, "a fala 'natural', dirigida aos espectadores, se ajusta a um protocolo de comunicação de coordenadas claras, na ação e no pensamento" 97 . Assim, a voz de Erica apresenta a característica de exprimir a crise aguda pela qual passa, realizando a mediação entre a imagem e o processo de estranhamento experimentado pelo personagem, fazendo com que o espectador adentre em seus pensamentos. É isso que ocorre após o primeiro assassinato cometido por Erica: ela é vista em seu apartamento, a lembrança dos tiros disparados contra o homem na loja de conveniência a assombra e ela arremessa a fita de vídeo que tem nas mãos - e na qual aparece - para longe. Mercer é visto em seguida, queimando fotos em que aparece ao lado de sua ex-esposa, após saber que ela se casará com outro homem. A voz de Erica começa a ser sobreposta desde a sequência que mostra Mercer. Erica, que é

\footnotetext{
96 Xavier, Ismail, "Corrosão social, pragmatismo e ressentimento: vozes dissonantes no cinema brasileiro de resultados”, op. cit., 2006, p. 139; grifos do autor.

97 Xavier, Ismail, op. cit., 2006, p. 140.
} 
vista um pouco mais tarde na sala gravando a própria voz como se estivesse pensando alto, revela seu estranhamento para consigo mesma: "É surpreendente, perturbador, descobrir que dentro de você existe uma pessoa estranha. Uma pessoa que tem seus braços, suas pernas, seus olhos. Uma estranha insone e irrequieta, que continua andando, comendo, vivendo". Enquanto Erica fala, vê-se Mercer adormecido sobre a mesa. A sequência, que de início propõe uma identificação entre os personagens através da dor advinda da perda, termina distinguindo-os: Mercer dorme vencido pelo cansaço, enquanto Erica permanece acordada.

Já os diálogos de Mercer apresentam "uma postura mais pedagógica, voltada para operações de costura e de informação" 98 acerca dos detalhes do trabalho policial. Em menor escala, isso se aplica também à fala de outros investigadores e da artistaforense.

A montagem sonora explora, ainda, as vozes como uma estratégia de conexão entre diferentes planos de imagens. É assim que as vozes invadem sequências que se passam em diferentes recortes espaço-temporais, dando a impressão de que a ação que se passa em uma dimensão espaço-temporal prolonga-se sobre outra. Em outros momentos, como quando Erica sai da delegacia de polícia depois de tentar se entregar, o uso das vozes em off dos jovens no metrô e do homem que sequestrara Chloe remetem às lembranças que a perturbam, trazendo ao presente vozes fantasmagóricas do passado. Dessa maneira, o espectador é transportado, através da montagem sonora, a outro tempo da narrativa. Aqui, e especialmente em relação à gravação das vozes que integram a narrativa, atribui-se uma dimensão espectral à voz, que se faz presente nas gravações dos crimes cometidos por Erica, mas também na mensagem da secretária eletrônica do casal gravada por David. As vozes dos mortos tornam presente sua ausência, numa chave diferente daquela proposta por Erica a respeito das fotografias de estabelecimentos da cidade que aparecem na exposição visitada por ela na primeira parte da narrativa. Ali as fotos evocam a ausência a partir de seu silêncio.

Ruídos e músicas integram também a montagem sonora. A utilização dos ruídos da cidade destaca-se nas gravações de Erica pelas ruas. Também o som associado ao elevador destaca-se na montagem, constituindo-se em pista para que Mercer relacione o assassinato de Murrow a Erica. Já as músicas, instrumentais em sua maioria, propõem pontos de tensão, suspense e distensão. $\mathrm{O}$ uso de cordas aparece mais frequentemente

98 Xavier, Ismail, op. cit., 2006, p. 140. 
associado à figura de David. O restante da trilha sonora ajuda a criar a ambientação de diferentes espaços, como o bar para onde Erica se dirige após os assassinatos no metrô.

Em Valente a violência aparece como espetáculo não apenas através de sua estética e de suas proposições de conteúdo. A espetacularização da violência torna-se parte da história por meio dos membros da gangue do Central Park, que filmam Erica e David sendo agredidos. Ali a referência é explícita: socos e pontapés são os focos da câmera do agressor que além de vibrar com o resultado "hollywoodiano", também reclama quando perde algum desdobramento da "cena". A transição entre o filme e o filme dentro do filme acontece pela utilização de imagens de qualidades e cores diferentes. $\mathrm{O}$ filme dentro do filme volta a aparecer ao fim da narrativa, sendo enviado ao celular de Erica pela namorada de um dos membros da gangue. Erica, por sua vez, reenvia as imagens para Mercer, sem que seja necessário que o espectador as veja novamente.

Ao estabelecer dois pontos de referência para o desenvolvimento da narrativa, Valente centraliza as situações de carência e de desafio em torno de Erica e Mercer, respectivamente. O ponto de referência que gira em torno de Mercer é mais estável no que se refere ao desafio, uma vez que sua inserção como policial estrutura-se nesta perspectiva. Já Erica transita entre a carência e o desafio: se o espancamento a coloca em uma situação de carência explícita - de segurança, de vida sexual e amorosa, de identidade - o desenvolvimento da narrativa converte o luto em um desafio, cujo resultado é, por um lado, o aparecimento e a aceitação de uma nova identidade, e, por outro, a reapropriação do espaço urbano a partir da sobrevivência e do enfrentamento da morte.

Em relação à Erica, a presença e ausência de alguns personagens em determinadas partes da narrativa marcam esta transição. Na primeira parte do filme, a presença de Nicole, amiga da protagonista, apresenta certas características do relacionamento de David e Erica: além de felizes, eles são um casal que parece bastar-se a si mesmo. Para agradar Erica, David comparece à exposição de fotografias organizada por Nicole, mas apenas para buscá-la. Na segunda parte do filme, quando Erica sai do hospital, Nicole lhe telefona, tentando convencê-la a sair de casa. Neste momento e quando Nicole a vê, próxima ao Strangers' Gate, Erica a ignora completamente. Erica despreza, assim, as relações que mantinha antes do espancamento, como se essas relações não pudessem trazer-lhe mais nenhum conforto.

Um personagem sem família, Erica tampouco se ancora na família de David 
após sua morte. A mãe do médico aparece somente uma vez e apenas como mensageira da notícia fatal. Já a relação de Erica com o trabalho é bastante diferente. Esta relação é mediada pela figura de Carol, sua chefe, uma vez que todos os demais funcionários da rádio têm pouca relevância. O trabalho como radialista permanece um forte atribuidor de sentido à vida de Erica e é nele que ela se apega logo depois que comete o primeiro assassinato. É através do trabalho, portanto, que Erica vai estabelecer novas relações com o mundo a seu redor. No entanto, ela não consegue dissimular as transformações internas de sua identidade: nos seus programas seguintes, suas relações com a cidade tornam-se metáfora das negociações internas pelas quais passa o personagem. Estabelece-se entre ela e Carol uma tensão por causa do tom confessional que o programa ganha, mas uma vez que a audiência aumenta, a chefe cede à mudança de sua tônica. Erica conhece Mercer e se utiliza de sua profissão como desculpa, primeiro para se afastar e depois para se aproximar dele. Suas incursões pela questão da violência urbana a colocam de frente com sua nova identidade num momento em que os habitantes da cidade discutem os crimes do vigilante. Em conflito, Erica tem uma crise nervosa em pleno ar e aparece na delegacia em seguida, tentando se entregar. A partir deste momento, o trabalho de Erica torna-se invisível na narrativa.

Erica é uma assassina em conflito moral. No entanto, o conflito interno não a impede de matar, ainda que tente. De um assassinato a outro, Erica ganha confiança enquanto se apropria de sua nova identidade. No primeiro, que poderia ser considerado como um crime em legítima defesa, Erica age impulsivamente, fechando os olhos enquanto atira. Sua reação ao crime é neste caso a mais exacerbada: Erica sente-se suja, mete-se embaixo do chuveiro, ainda vestida, ao chegar em casa. Torna-se insone. No segundo, ela age com mais segurança. Indaga-se sobre os motivos que a levaram a matar os dois jovens, uma vez que poderia ter utilizado a arma apenas para sair da situação de ameaça, e por que não há quem a detenha ${ }^{99}$. No entanto, sua reação física é menos intensa - ela vomita, mas lava o rosto e se controla, admirando a si mesma como se fora outra pessoa ao maquiar-se. Ainda que em conflito, ela gosta do que vê pelo espelho sujo do bar. No terceiro, Erica tenta preservar a vida do sequestrador de Chloe, mas atira nele quando o homem avança o carro na direção das duas. Erica não apresenta a partir de então mais nenhuma reação física a seus assassinatos. Parece-me que Erica mata Murrow para despertar as suspeitas de Mercer e ser finalmente detida. Após o

99 Da mesma maneira como não houve quem detivesse a agressão sofrida por ela e David no Central Park. 
assassinato dos membros da gangue, ela se entrega a ele, aceitando pagar por seus crimes. Erica é, portanto, uma vigilante construída numa perspectiva particular: seus crimes não se equiparam à justiça, ainda que a narrativa forneça ao espectador algumas justificativas para que eles ocorram.

A respeito dessas justificativas, certos conteúdos de conotação sexual permeiam as demonstrações de poder e violência que aparecem no filme. Assim, durante a agressão sofrida por Erica e David no Central Park, um dos membros da gangue tocalhe o seio. Após ser arremessada contra a parede pela primeira vez, seu agressor afirma que lhe tirou a virgindade. As ofensas dirigidas a David vinculam covardia e homossexualidade. Algo parecido acontece ao senhor que é ameaçado no metrô pelos jovens mortos por Erica: um dos jovens agarra sua cabeça posicionando-a em direção a sua pelve, enquanto provoca o filho do homem, perguntando-lhe se já havia visto seu pai naquela posição. Quando os jovens se dão conta da presença de Erica no vagão, ser mulher parece ser motivo para que seja facilmente rendida. O jovem a ameaça então com um canivete, sugerindo um possível estupro. A conexão entre sexo e violência se estabelece mais explicitamente no caso do sequestro de Chloe. A jovem aparece no interior do carro do sequestrador bastante fraca e debilitada, com uma queimadura próxima ao seio. É interessante notar que, ao ver Erica mostrar preocupação a respeito do estado físico de Chloe, o sequestrador a provoca perguntando se ela é mãe, para então confirmar se ela é uma prostituta, provavelmente por estar na rua tarde da noite. Quando Erica aponta a arma para sua cabeça ele a chama de super-vadia. Em relação às imagens, nos três momentos em que se propõe a possibilidade de violência sexual, a narrativa faz uso de planos de seios e colos.

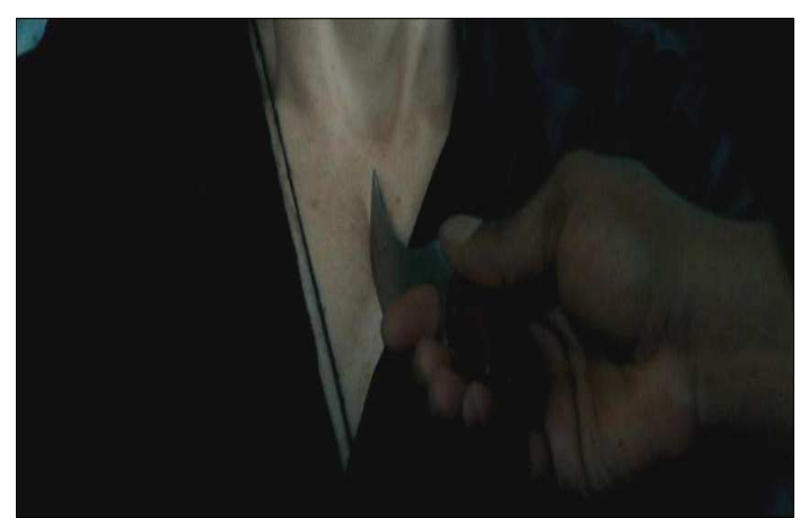

Há, dessa maneira, uma dimensão sexual na violência construída pela narrativa. No entanto, não é essa dimensão que prevalece. A associação entre sexo, violência e 
morte em Valente é muito mais visível nas vítimas de Erica que nela mesma, aparecendo, dessa maneira, mais fortemente vinculada aos personagens masculinos que são vistos na tela. No caso da protagonista, o sexo aparece associado primordialmente à vida e ao amor, de modo que não é de se estranhar que, a medida em que Erica se converte em vigilante, sua figura vá perdendo, paulatinamente, o apelo sexual e a beleza. Diferente do que ocorre em Sedução e Vingança, a associação entre sexo, violência e morte aparece aqui obliterada, prevalecendo em Erica a associação entre violência e poder. Em relação à arma de fogo, se há a dimensão de poder em sua posse, esta se expressa mais no início da narrativa, uma vez que Erica só volta a sentir-se segura quando consegue comprar sua pistola, e no fim da história, já que é a posse da arma de fogo que lhe garante levar sua vingança a termo. No entanto, entre um e outro momento, a violência que passa a fazer parte da nova identidade de Erica se expressa também pelo uso que ela faz de seu corpo. Isso acontece quando ela assassina Murrow seu crime mais pessoal, como afirma posteriormente Mercer: não conseguir pegar a arma há tempo não a impede de render sua vítima, apossar-se do cano que ele usara como arma contra ela e cometer, então, o homicídio.

Por mais que Erica se questione a respeito da necessidade de matar, a maior parte dos assassinatos que comete é construída na chave da legítima defesa. O assassinato de Murrow consolida, ao contrário, o posicionamento de Erica como vigilante. Na sequência, Erica se distingue dos policiais, sugerindo à Murrow que a história seria outra se ela o fosse. Há, portanto, neste momento, uma alusão a que polícia - e as demais instituições de justiça - não seriam capazes de impedir os crimes de Murrow, "responsabilidade" que Erica toma para si.

A polícia que se apresenta na narrativa atende às ocorrências depois que elas aconteceram e se utiliza de um amplo aparato forense. Nas delegacias, o cidadão é tratado com falsa cortesia, mas não consegue ser atendido. O trabalho policial parece mais eficaz na central de polícia, onde, não por acaso, Mercer se destaca entre os demais investigadores. Pode-se dizer que a narrativa propõe três tipos de policiais. O primeiro é aquele das delegacias, um burocrata dependente do sistema computacional. Sua função parece ser a de livrar-se dos cidadãos ou mandá-los esperar por alguém mais competente, que nunca é visto. O cidadão de Nova Iorque parece, assim, não ter nenhum respaldo do aparato policial. Em nenhuma das duas vezes em que Erica dirigiuse a uma delegacia, na primeira como vítima, na segunda como criminosa, ela 
conseguiu comunicar-se com este tipo de policial $^{100}$.

O segundo tipo de policial proposto pela narrativa é o investigador-padrão. Vários deles são vistos em diferentes momentos da narrativa, destacando-se Vitale, parceiro de Mercer. Vitale concentra as características de um tipo de policial que cede facilmente às percepções de senso comum: seu trabalho apoia-se em grande parte no aparato forense disponível, mas parece incapaz de estabelecer correlações entre as evidências. Esta é a maior capacidade de Mercer, o único exemplo de um bom policial, o do terceiro tipo. Outras qualidades colaboram para que ele apareça como um policial fora do comum: ele faz uso da intuição e da lógica, envolve-se emocionalmente com os casos e, por isso, persiste. Algo desperta o interesse dele por Erica, mas não fica claro se esse interesse tem uma conotação sexual, se advém dele ser ouvinte de seu programa, ou se se baseia simplesmente numa "intuição" policial.

A relação entre Mercer e Erica não é estabelecida imediatamente, dando-se, primeiramente, através da mediação da figura de Murrow. Mercer é chamado ao hospital para onde a mulher de Murrow fora levada, após ter, supostamente, se suicidado. Nesta ocasião, Mercer visita Erica quando ela ainda estava em coma. Eles voltam a encontrar-se após os assassinatos do metrô, quando Erica se aproxima da cena do crime ${ }^{101}$. Ele percebe sua presença e a chama, ela então se apresenta como radialista, supondo que isso o afastaria. Mercer despede-se e sai, mas no dia seguinte busca informações sobre o caso de Erica e David. Para surpresa de Erica, Mercer a procura e lhe concede uma entrevista. Erica, nesta ocasião, faz perguntas nada desinteressadas, buscando obter detalhes da atividade policial que poderiam levá-la a ser apanhada. O círculo que envolve a figura de Murrow volta a se fechar quando Mercer fala dele para Erica. A partir daí, Erica e Mercer voltam a se encontrar várias vezes nos dias seguintes. Conforme as pistas apontam para Erica, principalmente depois que ela assassina Murrow, Mercer começa a inverter o jogo das perguntas recheadas de segundas intenções. Assim, o barulho do elevador que Mercer escuta durante o telefonema de Erica e durante sua visita à cena do crime reconstrói o vínculo entre os personagens e

${ }^{100}$ A incapacidade da polícia é construída numa outra chave em Ato de vingança. Neste filme, várias mulheres estupradas pelo mesmo homem unem-se com o intuito de evitar novos abusos - pelo estuprador, cuja identidade desconhecem, e por outros homens. O esquadrão de vigilantes surge, assim, como resposta a uma inaptidão institucional para lidar com os casos de violência sexual contra mulheres.

101 Erica realiza, dessa maneira, um outro estereótipo acerca dos criminosos, que é o de voltar à cena do crime. Curiosamente, contudo, e talvez para adiar a vinculação de seu personagem a figura do vigilante (em relação a Mercer), a ideia de que os criminosos retornam à cena do crime não é mencionada na narrativa. 
será decisivo para que o detetive suspeite de Erica. O relacionamento dos dois é tão ambíguo que causa certa surpresa Mercer considerá-la a ponto de fornecer-lhe detalhes do caso, encaminhando a conversa que têm na lanchonete para um tom de advertência, dizendo-lhe que prenderia até mesmo uma pessoa que lhe fosse muito próxima.

Já a vizinha de Erica é um personagem que vai ganhando importância com o desenrolar da narrativa. Sua presença é geralmente breve: é alguém com quem Erica se encontra na entrada do prédio, troca poucas palavras e com quem, de início, tem pouca intimidade. Tida como uma pessoa antipática e taciturna, após a morte de David a vizinha mostra-se uma pessoa sensível que, apesar de não saber com exatidão o que se passa com Erica, percebe que algo não vai bem. Sua posição em relação a ela é de preocupação e de questionamento, não de julgamento moral. Neste sentido, a vizinha é o personagem que suspende as generalizações simples do que é bom ou mau. Quando Erica volta ferida ao prédio, é ela quem a socorre. Erica lhe confessa ser uma assassina. A vizinha, que não por acaso revela-se ser estrangeira, lhe conta, então, que em seu país de origem os soldados obrigavam as crianças a matar os próprios pais para provarem que qualquer um pode tornar-se um assassino.

Esse é, sem dúvida, o mote de todo o enredo. A tese de que qualquer um pode tornar-se um assassino é vivenciada por Erica e contraposta aos estereótipos que a narrativa mobiliza para caracterizar os criminosos. Em primeiro lugar, os criminosos são homens que têm antecedentes e que fogem dos locais dos crimes. Vitale é quem explicita o estereótipo mais associado a um criminoso ao afirmar que Sandy Combs se parece a um acompanhante da banda Aerosmith. A figura dele, no entanto, remete pouco a esta caracterização. Ele e os dois integrantes da gangue do Central Park aparecem, no entanto, exibindo frontes ameaçadoras e corpos brilhantes. As roupas escuras de Combs e do líder da gangue reforçam o sentido de ameaça associado aos seus personagens. Já o líder da gangue é o único que exibe tatuagens, distribuídas por todo o torso.
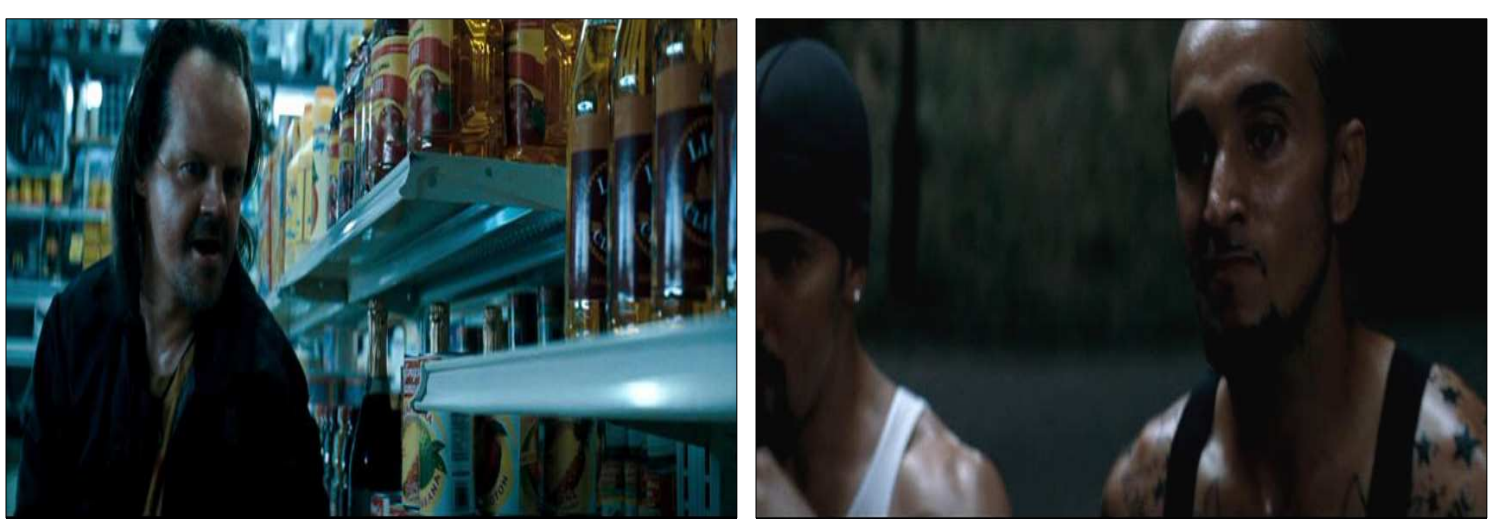
A possibilidade da criminalidade feminina não parece ser levada muito a sério. Em dois momentos, no entanto, mobilizam-se estereótipos sobre a violência feminina. No primeiro deles, quando Mercer e a ex-mulher conversam em um bar sobre o caso de Murrow e o desacreditado suicídio de sua esposa, Mercer afirma que, segundo sua experiência, as mulheres não atiram em si mesmas na cabeça, mas sim no coração, uma referência à emotividade feminina ou à incapacidade narcisista de desfigurar o próprio rosto, quem sabe. No segundo, enquanto Vitale e Mercer observam Ethan fazer o retrato-falado de Erica, Vitale refuta a possibilidade do vigilante ser uma mulher, uma vez que mulheres só matam pessoas que amam, como namorados, maridos e filhos. $\mathrm{O}$ estereótipo da violência feminina é proposto, portanto, na chave do passional. Mesmo quando Mercer provoca Erica na lanchonete dizendo que todo o tempo eles estavam buscando um homem com uma arma quando deveriam estar procurando uma mulher com rancor, a violência feminina é associada às emoções.

Não importam quais sejam as motivações ou situações que tenham levado Erica a matar, nem aqueles que levaram Mercer a encobrir seus crimes. Minha interpretação é de que a narrativa constrói como problema o estereótipo da violência feminina, contesta esse estereótipo, mas como o nega a partir do seu desfecho, o perpetua. É exatamente isso que acontece quando Mercer encobre Erica no final da narrativa. Valente é, portanto, um filme que aborda os estereótipos relacionados à violência urbana e a relativa invisibilidade dos crimes cometidos por mulheres, mas não os supera.

\section{A TEMÁtica da RetaliaÇão EM SEDUÇ̃̃o E VINGANÇA E VALENTE}

A partir de aspectos gerais, Sedução e Vingança e Valente são filmes muito parecidos. Ambos constroem suas narrativas a partir da figura de uma mulher que depois de sofrer uma agressão torna-se uma assassina. O termo vigilante aparece como uma atribuição da mídia em ambas as narrativas, remetendo a um assassino que faz justiça com as próprias mãos, desprezando a lei e a justiça. Em certo sentido, a ideia do filme de retaliação - ou do vigilante - acaba por guiar grande parte das análises de Sedução e Vingança ${ }^{102}$. Valente tende a ser analisado na mesma chave, ainda que a

\footnotetext{
${ }^{102}$ A este respeito, ver: Christensen, Terry; Hass, Peter J. Projecting Politics: Political Messages in American Film. Armonk: M.E. Sharpe, 2005, pp. 269-270; Clover, Carol J. Men, women, and chain saws: gender in the modern horror film. Princeton: Princeton University Press, 1992, pp. 138-143.
} 
obliteração do conteúdo sexual da violência construída pela narrativa tenha levado, no meu entender, críticos a compararem-no a filmes como, por exemplo, Desejo de Matar (Death Wish, Michael Winner, 1974) ${ }^{103}$. Minha interpretação, no entanto, estabelece-se a partir da percepção de que essa generalização encobre as especificidades destas narrativas $^{104}$.

Duas principais diferenças chamam atenção. A primeira refere-se aos atributos que fazem com que, de um lado, Thana apareça como um personagem mentalmente desequilibrado e Erica não. As duas mostram-se confusas, têm crises nervosas no trabalho e tornam-se insones. O fato de Erica ter uma voz que expressa seus conflitos internos parece-me ser fundamental para que sua figura torne-se capaz de despertar uma maior identificação com o espectador do que a figura de Thana. A violência expressada por Thana é, neste sentido, mais visceral. O poder da fala atribuído a Erica torna a expressão de sua violência mais inteligível, ainda que se apresente como uma força interna que ela não consegue controlar.

Assim, traça-se um interessante paralelo entre os dois personagens: a chance de Erica exprimir o que pensa e sente através da voz a humaniza, ao mesmo tempo em que torna o filme explicado em demasia - tudo parece passar pela palavra; a ausência da fala em Sedução e Vingança erotiza a vingança de forma a que a violência que daí emerge a supera. Tudo aquilo que escapa à "razão" e que está provocativamente presente na elaboração da fantasia masculina em Sedução e Vingança, aparece plenamente justificado em Valente. Se Valente recusa-se a elaborar essa fantasia, dá, por sua vez, voz ao ato de vingança, elaborando a violência através da palavra.

A segunda refere-se às relações que os personagens estabelecem nas narrativas. A inserção profissional de Erica confere-lhe um lugar muito diferente do ocupado por Thana. Suas relações são mais substantivas - ela não deixa de ser uma mulher solitária, mas por razões completamente diferentes das que fazem Thana o ser. Deste modo, a reação de Erica à agressão é construída numa chave mais melodramática do que a de Thana. É por isso que Valente só termina quando os agressores de Erica são mortos. Erica encontra a redenção na morte de seus agressores, é dessa forma que sua vingança se completa. Thana, ao contrário, ultrapassa os limites da vingança. A violência a

${ }^{103}$ A este respeito, ver: Scott, A.O. "Packing Heat After a Coldhearted Crime". In: The New York Times, 14/09/2007. Disponível via URL: http://movies.nytimes.com/2007/09/14/movies/14brav.html; acessado em 17/06/2009.

${ }^{104}$ Não deixa de ser curioso, no entanto, que haja entre as narrativas certas "coincidências" em relação aos personagens que integram as tramas. Os dois filmes utilizam-se de cachorros, de vizinhas e de chefes para compor o rol de seus personagens. 
completa.

Considerar que os filmes integram a mesma temática, seria de algum modo reconhecer que a ideia da retaliação é a que mais orienta a construção de suas narrativas. Minha interpretação é de que essas narrativas superam essa delimitação. Se, como foi mostrado, o problema de Sedução e Vingança reside no corpo feminino, o problema de Valente é o que se imagina que este corpo seja capaz de fazer. Valente, neste sentido, evidencia o principal problema sobre o qual me debruço aqui: as transformações, ocorridas no cinema do período, no imaginário que associa violência à figura feminina. Transformações estas que possibilitaram que a violência feminina deixasse de ser punida na tela do cinema.

Ao sediar a violência na figura de uma mulher, a ideia da retaliação revela, contudo, sua importância. Filmes que apresentam vigilantes, como Sedução e Vingança e Valente, exacerbam um elemento que se faz presente em muitas narrativas que apresentam mulheres violentas. A partir dos anos 1970, atos violentos cometidos por mulheres começaram a ser justificados por um evento anterior que serve de motor à ação. Neste contexto, são as circunstâncias que forçam ou levam a mulher a manifestar sua violência. Ao justificar a violência feminina desta maneira, a ideia da retaliação, por um lado, permite que um personagem feminino mostre seu conteúdo agressivo, amenizando - às vezes mais, como em Valente, às vezes menos, como em Sedução e Vingança - a estranheza causada pela associação da violência ao corpo feminino. Por outro, colabora para a permanência, no imaginário, da ideia de que a violência é exterior à figura feminina, que ela não lhe é "natural", reiterando os efeitos da docilização do corpo feminino pelo seu contrário. Ao fim, a mulher violenta se apresenta como outro. Não um outro que é masculino, mas um outro-feminino, que se desdobra tanto da loucura de Thana, quanto da reinvenção de Erica. Os caminhos que tornam possível considerar Thana e Erica como outros-femininos, do e no cinema, são abordados no capítulo seguinte. 


\section{Capítulo II - O Surgimento da guerreira como Personagem CINEMATOGRÁFICO}

$\mathrm{Na}$ constituição das diversas possibilidades de narrativa fílmica, a linguagem cinematográfica incansavelmente atribui formas às sensações e emoções, aos comportamentos e movimentos. Por um lado, no que se refere às histórias relatadas, criam-se conjuntos que, ao se reproduzirem em diversos filmes, padronizam tramas e tipos de personagens, algo que, não raro, acaba por encobrir suas singularidades. Por outro lado, grande parte das características da narrativa diz respeito não a sua história, mas às opções de sua constituição, e às estratégias utilizadas na proposição de seus sentidos - como a captura das imagens e dos sons, os enquadramentos e, especialmente, a montagem. A narrativa compreende, portanto, não apenas a história contada pelo filme, mas as estratégias utilizadas para a construção de suas articulações, e, portanto, para a proposição de seus sentidos, cujos significados dependem não só do que se vê, mas de como se mostra o que se vế ${ }^{1}$.

A maneira como cada filme constrói suas articulações e propõe seus sentidos revela-se especialmente relevante no que tange à significação da violência. Paulo Menezes chama atenção, ao dedicar-se à análise de Laranja Mecânica, para a fluidez da definição de violência neste filme, apresentada que é a partir de várias formas e imagens diferentes, tanto no que se refere à violência física propriamente dita, quanto à psicológica e política ${ }^{2}$. Considerando ainda o mesmo filme, Edilson Atsuo Saçashima lembra que suas imagens mais sugerem que mostram a violência, de modo a que, se os espectadores as tomam como violentas, isto se dá pela projeção de valores sobre aquilo que se vê na tela ${ }^{3}$. A respeito de como se mostra e como se percebe a violência no cinema, Hilary Neroni diz que há uma inegável dimensão espetacular relativa à violência fílmica, dimensão esta que se realiza, contudo, apenas por meio da narrativa ${ }^{4}$.

Cf. Carrière, Jean-Claude, A linguagem secreta do cinema, op. cit., 1995, p. 58.

Cf. Menezes, Paulo, À meia-luz: cinema e sexualidade nos anos 70, op. cit., 2001, pp. 56-57.

Cf. Saçashima, Edilson Atsuo, A Questão da "Violência" no Cinema de Stanley Kubrick, op. cit., 2007, p. 116.

4 Neroni, portanto, contrapõe-se tanto aos autores que veem na violência um elemento não-narrativo, ou seja, como puro espetáculo - um elemento distinto do filme, dotado de uma lógica, estrutura e relação própria com o espectador -, bem como aos autores que vem na violência um elemento fílmico como qualquer outro, indistinto. Para ela, há, neste sentido, uma narratividade associada à violência fílmica. Considerando a importante função ideológica do cinema, Neroni vê na violência um elemento que pode tanto reforçar quanto desafiar a funcionalidade de ideologias. Cf. Neroni, Hilary. The violent 
Deste modo, por ser um conceito fluído, impregnado de moralidade, cada narrativa estabelece o pano de fundo sob o qual a violência adquire sua importância e significado.

Desde o aparecimento de Alien (Ridley Scott, 1979), afirma-se que o cinema vem construindo um novo padrão de exercício da violência feminina na tela. Este padrão teria, de acordo com uma série de autores, ganhado fôlego durante a década de 1990, espalhando-se por vários tipos de narrativas fílmicas durante a primeira década dos anos 2000. Dessa maneira, para Neroni, até muito recentemente, a violência aparecia na tela como uma atividade primordialmente masculina, embora tenha havido períodos em que diferentes tipos de narrativas apresentassem, esporadicamente, mulheres violentas. De acordo com ela, é a partir dos anos 1980 que a violência feminina teria se espalhado por uma variedade de tipos de narrativas ${ }^{5}$. Já para Neal King e Martha McCaughey foi durante a década de 1990 que isto efetivamente aconteceu. Antes confinada em filmes de baixo orçamento, principalmente durante as décadas de 1960, 1970 e 1980, Alien e O Exterminador do Futuro 2 (Terminator 2: Judgement Day, James Cameron, 1991) foram os filmes que teriam marcado o aparecimento deste novo padrão no cinema hollywoodiano. Estes filmes, bem como Nikita (Luc Besson, 1990), O Silêncio dos Inocentes (The Silence of the Lambs, Jonathan Demme, 1991) e Thelma e Louise (Thelma \& Louise, Ridley Scott, 1991) teriam sido os primeiros a despertar o interesse dos meios de comunicação de massa e dos estudiosos sobre o cinema para as transformações que fizeram com que a figura feminina deixasse de se apresentar como vítima da violência para tornar-se algoz ${ }^{6}$. Por outro lado, Sherrie A. Inness identifica, neste mesmo período, uma explosão de aparições da violência feminina também em outros meios, como a televisão, os quadrinhos e os videogames. Ao considerar todas essas manifestações e produtos culturais, Inness chama atenção para a longevidade de uma figura feminina forte na cultura norte-americana. Para ela, contudo, o sucesso de personagens como Ellen Ripley de Alien e Sarah Connor de $O$ Exterminador do Futuro 2 foi responsável pela explosão que se deu no cinema dos anos seguintes. Assim, nos termos de Inness, se mulheres fortes já faziam parte de um imaginário norte-americano, a especificidade do momento mais recente, além do aumento dramático do número de suas aparições, advém da utilização de uma estética

woman: femininity, narrative, and violence in contemporary American cinema. Albany, NY: State University of New York Press, 2005, pp. 2-8.

5 Cf. Neroni, Hilary, op. cit., 2005, p. ix.

6 Cf. King, Neal; McCaughey, Martha. "What's a mean woman like you doing in a movie like this?". In:___ (eds.) Reel knockouts: violent women in the movies. Austin, TX: University of Texas Press, 2001, pp. 4-5. 
diferenciada, em que a figura feminina aparece mais musculosa e agressiva do que no passado. Além disso, essa nova mulher mostra-se independente, pois já não precisa de uma figura masculina para vir em seu socorro ou resgatá-la do perigo. Desse modo, para esta autora, as imagens de personagens deste tipo apresentam-se como imagens da liberação feminina das restrições da estrutura de dominação de gênero ${ }^{7}$. Já Dominique Mainon não parece estar tão segura a este respeito. A autora conta, entretanto, como tais imagens despertaram seu interesse na primeira metade dos anos 2000, ao dar-se conta da "naturalidade" com que a violência dos personagens femininos dos dois volumes de Kill Bill fora construída nas tramas. Mainon percebeu esta mesma "naturalidade" em vários outros filmes dos anos imediatamente seguintes, como Rei Arthur (King Arthur, Antoine Fuqua, 2004), Sr. e Sra. Smith (Mr. \& Mrs. Smith, Doug Liman, 2005), Resident Evil - Apocalipse (Resident Evil: Apocalypse, Alexander Witt, 2004), O Clã das Adagas Voadoras (Shi mian mai fu, Yimou Zhang, 2004), Quarteto Fantástico (Fantastic Four, Tim Story, 2005), Anjos da Noite - A Evolução (Underworld: Evolution, Len Wiseman, 2006) e Sin City - A Cidade do Pecado (Sin City, Frank Miller, Robert Rodriguez e Quentin Tarantino, 2005). Suas imagens, inseridas, portanto, em diversos tipos de narrativas, aliam, segundo ela, força e sensualidade à figura feminina, de modo que as mulheres desses filmes deixam de aparecer simplesmente como as vítimas gritantes de antes, para converterem-se em personagens guerreiros, vingativos, furiosos e maus ${ }^{8}$.

Em face destas diferentes percepções, este capítulo dedica-se, em primeiro lugar, a reconstruir o percurso que tornou possível considerar este padrão de exercício da violência como novidade e os problemas que, a partir dele, se apresentam, de modo a discutir de que maneira este novo padrão pode ter engendrado uma possível ressignificação do feminino por meio de um novo tipo de personagem. Para tanto, num primeiro momento, serão abordados alguns dos principais tipos de personagens femininos construídos pelo cinema, chamando a atenção para aqueles que possivelmente contribuíram para o surgimento do tipo de personagem que expressa este novo padrão. Em segundo lugar, neste capítulo problematiza-se a maneira como diferentes autores perceberam o surgimento de personagens femininos violentos no

7 Cf. Inness, Sherrie A. “'Boxing gloves and bustiers': new images of tough women”. In: (ed.). Action chicks: new images of tough women in popular culture. Nova Iorque: Palgrave Macmillan, 2004, pp. 1-9.

8 Cf. Mainon, Dominique; Ursini, James. The modern amazons: warrior women on-screen. Pompton Plains, NJ: Limelight Editions, 2006, pp. xi-xxi. 
cinema, de modo a sublinhar, em relação ao imaginário, a especificidade da violência que expressam.

\section{OS FEMININOS DO CINEMA: ALGUNS TIPOS DE PERSONAGENS}

A constituição da narrativa de qualquer filme estabelece certos padrões de comportamento e de ação que só se materializam pela articulação de suas imagens e sons. No que se refere especificamente à aparição de personagens femininos, Jackie Byars conta que, desde o fim dos anos 1960, vários estudiosos dedicaram-se a examinar imagens de mulheres no cinema, debruçando-se sobre como foram apresentadas mulheres mais ou menos ajustadas aos padrões estabelecidos no interior de vários tipos de narrativas fílmicas. Estes estudos geralmente dão ênfase aos lugares sociais ocupados pelas mulheres, quais estereótipos os legitimam e que relações estabelecem-se entre as construções dos femininos no cinema e os contextos sociais de cada época ${ }^{9}$. Tendo em vista o cinema norte-americano, pode-se dizer que durante a primeira metade do século vinte, a caracterização dos diferentes tipos de personagens femininos orbitava ao redor de dois grandes "modelos" de feminilidade.

O primeiro deles está profundamente vinculado ao paradigma de feminilidade, construído durante todo o século dezenove, e que tinha como principais características femininas a devoção, a pureza, a submissão e a domesticidade ${ }^{10}$. De acordo com Gilles Lipovestky, a construção social da mulher voltada ao lar como um modelo normativo que se deu no século dezenove, elaborou-se a partir da negação da mulher como indivíduo, igual e independente. No século vinte, ocorreu, no entanto, uma dignificação da imagem social desta mulher, por meio da difusão de princípios racionais de organização no ambiente doméstico que reverberaram nas relações das mulheres com o consumo, o trabalho doméstico e a criação dos filhos. De acordo com este autor, tal dignificação, alicerçada na depreciação da mulher ativa, é resultado de

um processo de reconhecimento e de celebração das funções femininas, inseparável das sociedades da igualdade. Esposa, mãe, educadora, dona de casa: estes são os papéis da mulher levados às nuvens, julgados com

9 Cf. Byars, Jackie. All that Hollywood Allows - Re-reading Gender in 1950s Melodrama. Londres: Routledge, 1991, pp. 67.

10 Cf. Singer, Ben. "Female Power in the Serial-Queen Melodrama: The Etiology of an Anomaly". In Abel, Richard (ed.). Silent Film. New Brunswick, NJ: Rutgers University Press, 1996, p. 178. 
consideração, dotados em princípio de um valor igual aos que cabem aos homens ${ }^{11}$.

No cinema, a elaboração simbólica das questões que se relacionam à tal modelo faz-se presente principalmente no que se convencionou chamar de melodrama, e que Ben Singer, não por acaso, chama de melodrama doméstico ${ }^{12}$. Como a denominação de Singer sugere, nele, quanto mais próximo à vida privada, mais ajustado é o personagem à figura feminina promovida como socialmente "desejável". De acordo com Byars, este modelo, que apresentava as figuras da esposa, da mãe e da filha nas suas mais variadas formas, tornar-se-ia a única alternativa verdadeiramente viável de feminilidade no cinema norte-americano a partir dos anos $1950^{13}$. Neste sentido, os personagens femininos de filmes em que a vida privada tem pouca visibilidade geralmente são apresentados como secundários ${ }^{14}$, especialmente até o fim da década de 1970, quando começam a ter êxito de público e crítica filmes que subvertem a primazia de personagens femininos no ambiente privado e de personagens masculinos nos espaços público e social ${ }^{15}$.

Contudo, no início do século vinte, como relata Ben Singer, o que se entendia por melodrama apresentava histórias bem diferentes daquelas que construíam o sentimentalismo e primazia da vida privada com que se associam o melodrama nos dias atuais. Neste sentido, o seu espaço primordial não era o do âmbito doméstico, mas sim o dos espaços externos, onde se desenvolviam histórias recheadas de elementos de "ação", de suspense sensacionalista e de violência física, que construíam uma estética da calamidade e do espanto característica de uma literatura e de um teatro populares ${ }^{16}$. O segundo modelo de feminilidade possível, neste momento, mantém profunda relação com esta acepção de melodrama, pois ali foi onde floresceu algumas das elaborações que construíram a Nova Mulher norte-americana: aquela dos grandes centros urbanos,

11 Lipovetsky, Gilles. La tercera mujer. Barcelona: Editorial Anagrama, 1999, p. 200.

12 Cf. Singer, Ben, "Female Power in the Serial-Queen Melodrama: The Etiology of an Anomaly", op. cit., 1996, p. 166.

13 Cf. Byars, Jackie, All that Hollywood Allows, op. cit., 1991, p. 77.

14 Tome-se como referência os principais personagens femininos da série de filmes de James Bond (vinte e dois filmes realizados entre 1962 e 2008). Com frequência, as "Bondgirls" (termo utilizado no site oficial da série para designar as heroínas de cada filme da série, disponível via URL: http://www.jamesbond.com, acessado em 03/08/2005) são personagens ambíguos, vilãs em potencial que são cooptadas ou seduzidas pelo espião, apresentando-se assim, subordinadas ao herói.

15 Como ocorreu com Alien, vencedor de oito prêmios entre 1979 e 1980 e Kramer x Kramer (Kramer vs. Kramer, Robert Benton, 1979) vencedor de trinta e seis prêmios entre 1979 e 1981.

16 Cf. Singer, Ben, "Female Power in the Serial-Queen Melodrama: The Etiology of an Anomaly", op. cit., 1996, p. 166. 
ativa e independente, dotada de desejos próprios e que explorava os espaços negados à maioria das mulheres da época, ou seja, os espaços público e social. Segundo Singer, "as marcas da Nova Mulher - energia, independência, contato direto com o mundo extra-doméstico - eram, claramente, os termos de uma feminilidade revisada" ${ }^{17}$, cujos aspectos principais associavam-se, geralmente, a uma masculinização do feminino. Dessa maneira, nas narrativas do período, diferentes personagens elaboravam, pelo ajuste e pelo desajuste às histórias em que apareciam, as vicissitudes da vida feminina metropolitana $^{18}$. De acordo com Janet Staiger, enquanto os personagens ajustados indicavam uma abertura para uma cultura de cultivo de desejos femininos próprios e um movimento em direção à vida ativa, os personagens femininos desajustados apresentavam-se, em geral, como suporte para a normatização de comportamentos socialmente tidos como adequados às mulheres. Entretanto, diz ela,

num período de transição para uma sociedade industrial, urbana, multicultural, global e consumista, o debate sobre os significados da Nova Mulher não envolvia apenas questões de gênero. Uma Nova Mulher era necessária para a nova ordem. Mulheres eram necessárias em um mercado de trabalho heterossocializado; mulheres eram necessárias como consumidoras nas exóticas lojas de departamentos; mulheres eram importantes para a expansão do consumo nos campos do prazer e do lazer ${ }^{19}$.

O imaginário que criava uma Nova Mulher ajustada à nova ordem encontrou limites na década de 1930, dado o impacto da crise econômica sobre as escolhas ocupacionais femininas $^{20}$, e, mais ainda, após o fim da Segunda Grande Guerra Mundial quando - apesar de propagar-se um imaginário que restabelecia o espaço do feminino como primordialmente doméstico - muitas mulheres permaneciam, todavia, economicamente ativas ${ }^{21}$. A "vigência" destes dois modelos é mais perceptível, portanto, nas duas primeiras décadas do século vinte. A partir de então, é possível relacionar a caracterização de diferentes personagens femininos a um constante tensionamento em relação à construção da figura feminina como sujeito ativo e

17 Singer, Ben, op. cit., 1996, 178.

18 A construção da figura da mulher sozinha e os perigos a que se sujeita na cidade tem, portanto, suas origens neste momento.

19 Staiger, Janet. Bad Women - Regulating Sexuality in Early American Cinema. Mineápolis/Londres: University of Minnesota Press, 1995, p. 179.

20 Cf. Staiger, Janet, op. cit., 1995, pp. 181-182.

21 Cf. Byars, Jackie, All that Hollywood Allows, op. cit., 1991, pp. 79-80. 
independente.

Ao analisar o fenômeno do estrelato no cinema de grande parte do século vinte, Edgar Morin propõe que, ao mesmo tempo em que o amor ganha importância nas narrativas do início do século, o rosto feminino ganha destaque. Rostos desconhecidos e adoráveis convertem-se, segundo o autor, nas novas vedetes que iriam cristalizar o sistema do estrelato nos Estados Unidos e Europa entre 1913 e 1919, propagando um modelo de imagem feminina baseado em ideais de beleza, juventude e apelo sexual ${ }^{22}$. De acordo com este autor, durante a era gloriosa do estrelato alguns tipos de personagens polarizam as aparições masculinas e femininas na tela ${ }^{23}$. Quatro seriam os tipos de personagens femininos a destacarem-se entre 1920 e 1932: a virgem, a vamp, a mulher fatal e a divina.

A virgem, inocente ou rebelde, tem sua figura ancorada em atrizes como Mary Prickford, Lilian Gish e Suzanne Grandais, cujos rostos expunham grandes olhos crédulos e lábios ora entreabertos, ora levemente sarcásticos ${ }^{24}$. Para Ismail Xavier, Lilian Gish destaca-se entre as atrizes que interpretaram as virgens de D.W. Griffith, porque encarnava melhor que qualquer outra, o imaginário de feminilidade griffithiano:

(...) um imaginário de feição patriarcal, onde o feminino de celulóide e o feminino real compõem-se de figuras frágeis dentro das roupas[,] mas firmes no espírito, a virtude da mulher se fazendo dessa mescla de força de vontade e inocência desprotegida ${ }^{25}$.

A lógica melodramática protestante dos filmes dirigidos por Griffith durante o período Gish (1917-1922) é, segundo Xavier, exemplar. Nela,

a inocência carece de proteção num mundo de conspirações e ofensas; os vilões manifestam, sob diferentes máscaras, as artimanhas do Arquivilão do imaginário cristão; na combinação de fatalidade e intenções (boas e más), o

22 Cf. Morin, Edgar. As estrelas: mito e sedução no cinema. Rio de Janeiro, José Olympio, 1989, p. 7.

23 A tipologia de personagens apresentada por Morin apresenta-se imbricada à periodização que faz o autor do fenômeno do estrelato. Por essa razão, é possível afirmar, como Morin faz, que determinados tipos de personagens se destacam ou polarizam as aparições de estrelas do cinema nestes períodos, não que estes tipos de personagens tenham surgido neles. É dessa forma que a vamp se apresenta como um dos tipos de personagens que predominam durante a era gloriosa, que se estende, segundo o autor, entre 1920 e 1932. No entanto, o filme que apresenta Théda Bara como ícone da figura da vamp, A Fool There Was (Frank Powell, 1915), é anterior.

24 Cf. Morin, Edgar, op. cit., 1989, p. 8.

25 Xavier, Ismail. D.W.Griffith: o nascimento de um cinema. São Paulo: Brasiliense, 1984, p. 71. 
agente do Mal e a Providência disputam as rédeas do destino ${ }^{26}$.

A partir desta lógica, consolidou-se o modelo griffithiano de melodrama, cuja estrutura narrativa pode ser dividida em sete partes. A primeira, introdutória, apresenta (através de intertítulos) o tipo de história e a lição de moral subjacente a ela. $\mathrm{Na}$ segunda, apresentam-se os dados do equilíbrio inicial, seu espaço e seus personagens, que podem aparecer num quadro de harmonia estável ou de um equilíbrio instável. $\mathrm{Na}$ terceira parte dá-se a ruptura do estado inicial por intermédio da ação de um agente externo. Na quarta parte, que Ismail chama de purgatório, quebra-se a promessa de felicidade feita aos personagens, fazendo-os expiar qualquer culpa que possam carregar através do sofrimento. Na quinta parte ocorre um encontro providencial ou o retorno dos personagens ausentes durante a parte anterior, num momento em que se renova a promessa de felicidade através do acaso ou do fim da espera. A esta parte sucede um momento de suspense, que é o da dúvida se a promessa de felicidade será cumprida, geralmente imposto por intermédio de novos desafios que os levarão ao combate decisivo. A parte conclusiva da narrativa emerge, então, com o final feliz, a realização da promessa de felicidade, que aparece como destino num mundo pleno de sentido, no qual a harmonia fora novamente restabelecida ${ }^{27}$.

O imaginário da pureza feminina permanece atrelado também em relação às virgens rebeldes, fundamento de seu ajustamento. Entre elas, as heroínas dos serial queen melodramas ${ }^{28}$ destacam-se como personagens cujos principais atributos advêm de seu espírito aventureiro e relativamente independente. Hilary Neroni defende que estes foram os primeiros personagens femininos que, no cinema norte-americano, fizeram uso da violência. Cada série mostrava as diversas situações de perigo que a protagonista enfrentava para salvar a si mesma ou a alguém a quem amava, o que, por vezes, a obrigava a ser violenta para defender-se. Quando se envolvia em situações das quais não poderia livrar-se, era inevitavelmente salva por um personagem masculino,

Xavier, Ismail, op. cit., 1984, p. 80.

Cf. Xavier, Ismail, op. cit., 1984, pp 80-82.

28 A adição do termo melodrama aos filmes em que se apresentavam as serial queens é de Ben Singer, ao apontar para a diferente percepção que se tinha do melodrama na época da produção destes filmes e sua relação com as classes trabalhadoras e populares. O termo queen refere-se ao protagonismo feminino que se fazia presente nestas narrativas e o termo serial faz menção à divisão das histórias em vários episódios. Cf. Singer, Ben, "Female Power in the Serial-Queen Melodrama: The Etiology of an Anomaly", op. cit., 1996, p. 165-170. Assim, um grande número de serial queen melodramas foram produzidos entre 1912 e 1925 . Cada série tinha entre seis e doze episódios, exibidos semanalmente nos cinemas. Cf. Neroni, Hilary, The violent woman, op. cit., 2005, p. 16. 
algo que, geralmente, acontecia no final da série ${ }^{29}$. Para Neroni,

ainda que estas mulheres fossem capazes de ser violentas, rebeldes, independentes e aventureiras, as séries invariavelmente construíram suas heroínas como mulheres virtuosas, inteiramente destituídas de qualquer tendência à promiscuidade. A castidade e a proteção masculina são, sem sombra de dúvida, os elementos que tornaram possível que essas mulheres gozassem da aventura e da liberdade - e até mesmo da violência ${ }^{30}$.

Neste momento, a vamp e a mulher fatal podem ser consideradas como os tipos de personagens femininos com problemas de ajustamento às histórias em que apareciam. A vamp seria a mulher que, sem misericórdia, faz uso de sua sexualidade para manipular os homens, levando-os à ruína ou mesmo à morte, como acontece em $A$ Fool There Was. Já a mulher fatal pode ser descrita como a mulher sexualmente atraente que, com frequência, causa problemas aos homens com quem se envolve, subvertendo suas identidades, como acontece em $O$ anjo azul (Der Blaue Engel, Josef von Sternberg, 1930). Há, assim, uma certa proximidade entre estes dois tipos de personagens. Segundo Morin, "a vamp, saída das mitologias nórdicas, e a grande prostituída, saída das mitologias mediterrâneas, diferenciam-se e se confundem no seio do grande arquétipo da femme fatale ${ }^{31}$, que se universaliza rapidamente durante a década de 1920.

Pode-se afirmar, contudo, que entre os personagens de Théda Bara em A Fool There Was, e de Marlene Dietrich em O Anjo Azul, a capacidade destrutiva da sexualidade feminina aparece menos intensamente na segunda narrativa. Isto ocorre, em primeiro lugar, em relação ao destino de cada uma de suas "vítimas". Se a Vampira ${ }^{32}$ aparece como a imagem da maldade e do horror junto ao corpo sem vida do Sr. Schuyler na sequência final de A Fool There Was, Lola Lola reinicia seu ciclo de atração no cabaré, enquanto o Professor Immanuel Rath cede à exaustão agarrado à mesa de sua antiga sala de aula. Apesar da ambiguidade com que ele aparece na sequência final de $O$ Anjo Azul, a cena propõe concomitantemente a esperança de

Cf. Neroni, Hilary, op. cit., 2005, pp. 16-18.

Neroni, Hilary, op. cit., 2005, p. 18.

Morin, Edgar, As estrelas, op. cit., 1989, p. 8; grifos do autor.

32 Assim é chamado o personagem de Théda Bara em A Fool There Was, que não aparece como uma vampira propriamente dita. A denominação, neste sentido, alude aos aspectos mais "ameaçadores" da sexualidade feminina construídos pela narrativa. 
sobrevivência do personagem e uma tentativa de resgate de sua identidade, ainda que ele, explicitamente, já não seja reconhecido como pertencente àquele lugar. Em segundo lugar, a capacidade destrutiva da sexualidade feminina é mais intensa em A Fool There Was do que em $O$ Anjo Azul porque, no primeiro filme, a sexualidade da Vampira simboliza uma ameaça à família e à feminilidade burguesas. A feminilidade burguesa aparece em todas as suas facetas através das figuras da filha de Schuyler (a criança cuja felicidade é destruída pela ausência do pai), da sua cunhada (a jovem que se realiza pela conquista de um bom partido, o melhor amigo de Schuyler) e sua própria esposa (com quem a Vampira rivaliza diretamente). Ao destruir o casamento de Schuyler, a Vampira acaba por impedir a reprodução da ordem burguesa, que tem na família e no matrimônio algumas de suas principais instituições. Este poder é neutralizado em $O$ Anjo Azul, uma vez que Rath é solteiro. Já não é a família que está em jogo, mas sim o lugar da sexualidade feminina na ordem social. O perigo que ela representa à estrutura burguesa só se realiza em casos excepcionais, como o de Rath que, ao casar-se com Lola Lola é excluído, tornando-se motivo de chacota. O personagem é, dessa maneira, construído a partir de uma distância em relação aos demais homens da narrativa: dono de uma moral que o impede de compartilhar as regras do jogo social, ele acaba aparecendo como um homem ingênuo, incapaz de reconhecer o lugar e a função da prostituta em sua sociedade. Isolada no cabaré - o lugar da realização da "ameaçadora" sexualidade feminina -, a prostituta também se situa num lugar apartado, distante e inacessível à mulher ajustada aos padrões de adequação da narrativa, simbolizada pela figura da empregada de Schuyler. Neste sentido, ele torna-se o espelho invertido da femme fatale: por estarem longe da média, individualizam-se os perigos que ambos simbolizam. Dissociando-os dos demais, neutraliza-se, assim, a ameaça que ambos poderiam significar à manutenção da ordem social.

A partir daí, a sensualidade da femme fatale será incorporada, em diferentes medidas, por outros tipos de personagens. Tendo como seu maior expoente Greta Garbo, a divina aparece, segundo Morin, transcendendo a femme fatale pela pureza de sua alma. Um tipo de personagem intermediário entre ela - misteriosa, sensual e soberana nos seus figurinos insinuantes - e a virgem - pura e destinada ao sofrimento, que transparece por meio dos olhares intensos - em que a sexualidade do corpo feminino aparece apaziguada pela alma, a divina alimenta o imaginário sobre uma bela 
mulher de sonhos inacessíveis, que sofre e faz sofrer ${ }^{33}$.

Morin conta que, após a crise de 1929, o final feliz se impõe majoritariamente aos roteiros norte-americanos ao mesmo tempo em que se exacerba uma ilusão de maior realismo no que se refere às histórias e seus personagens ${ }^{34}$. Os grandes tipos de personagens presentes na era gloriosa do cinema hollywoodiano atualizam-se "naturalizando-se" - mas sem necessariamente desaparecer por completo ${ }^{35}$. As narrativas diversificam-se, e o romance invade diferentes tipos de narrativas. No que se refere aos personagens femininos, a virgem passa a aparecer cada vez mais como uma mulher chique que é amante e companheira ${ }^{36}$. Já a mulher provocante utiliza-se do apelo sexual da antiga vamp:

a antiga vamp, ao desagregar-se, libertou uma energia erótica que se distribuiu por todos os outros tipos de estrela. A mulher chique desinibida, cantora de cabaré ou bailarina de teatro de revista, já incorporava parte do sex-appeal da vamp. Paralelamente, a ex-vamp tornava-se, ela própria, uma mulher chique sob aparência provocante ${ }^{37}$.

A aparência feminina provocante aparece de forma marcante na femme fatale dos filmes noir, produzidos principalmente a partir da década 1940. De acordo com Morin, os principais personagens dos noir emergem da conjugação de atributos bons e maus, libertando uma grande energia erótica na tela ${ }^{38}$. Segundo Hilary Neroni, a femme fatale construída por estas narrativas tem como atributos gerais a personalidade autocentrada, a sexualidade aparente e a habilidade de seduzir quase todo homem que cruzasse seu caminho em cena, apresentando-se quase sempre como uma mulher

33 Cf. Morin, Edgar, op. cit., 1989, p. 8.

34 De acordo com Ismail Xavier, esta ilusão de um maior realismo está ancorada na adoção de critérios naturalistas, que resulta numa construção que se pretende fiel à aparência das coisas do mundo físico e do comportamento humano. “Em todos os níveis, a palavra de ordem é 'parecer verdadeiro'; montar um sistema de representação que procura anular a sua presença como trabalho de representação. (...) Tal modelo [da decupagem clássica] representa uma convergência radical entre a construção de um discurso que se quer transparente (efeito de janela/fluência narrativa) e a modelagem precisa de uma dupla máscara: para propor uma ideologia como verdade, tal máscara insinua-se na superfície da tela (produzindo os efeitos ilusionistas) e insinua-se na profundidade e na duração produzidas por estes efeitos (produzindo as convenções do universo imaginário no qual o espectador mergulha)". Xavier, Ismail, $O$ discurso cinematográfico, op. cit., 2005, p. 42 e p. 46.

35 Cf. Morin, Edgar, As estrelas, op. cit., 1989, pp. 9-14.

36 Para Morin, o companheirismo aparece como um atributo masculino, o que faz com esta mulher chique apareça como uma figura que carrega, de certa forma, uma ambiguidade entre feminino e masculino. Cf. Morin, Edgar, op. cit., 1989, p. 14.

37 Morin, Edgar, op. cit., 1989, p.15; grifos do autor.

38 Cf. Morin, Edgar, op.cit., 1989, p. 16. 
glamurosamente bela, cujo corpo é coberto por figurinos altamente estilizados ${ }^{39}$. Contudo,

presa à famosa mise-en-scène (influenciada pelo expressionismo alemão) composta por sombras extremamente contrastadas em um cenário urbano, a femme fatale parecer ganhar vida das profundezas das sombras da cidade que, ao final, a engolirão. A mise-en-scène exagerada, que lhe fornece o pano de fundo, acaba por enfatizar que ela é a personificação da "moça má" 40.

Mesmo que o exercício da violência não seja considerado por Neroni como um dos atributos que definem a femme fatale dos noir, ela se faz presente como um subproduto de sua "personalidade":

o destino da femme fatale geralmente envolve violência: ou ela encontra uma morte violenta ou recorre ao seu uso. (...) Apesar de ela exercê-la com habilidade e sem arrependimento, a violência da femme fatale, com frequência, parece ser seu último recurso. Dentro do contexto dos filmes, seu ato violento marca-a como verdadeiramente má e perigosa ${ }^{41}$.

Ainda segundo esta autora, neste período, a violência feminina era um terreno que pertencia apenas à femme fatale. Assim, para se revelar violento, qualquer personagem feminino necessariamente deveria ser construído em referência a ela ${ }^{42}$. É, portanto, a partir da figura da femme fatale que se propõe uma associação entre sexo, maldade e violência, o que exercerá, a partir de então, grande influência na maneira como a violência feminina é construída e apreendida a partir do cinema ${ }^{43}$.

Com relação aos demais personagens femininos, Morin conta que é também a

39 Cf. Neroni, Hilary, The violent woman, op. cit., 2005, p. 22.

40 Neroni, Hilary, op. cit., 2005, p. 22; grifos meus.

41 Neroni, Hilary, op. cit., 2005, p. 23; grifos meus.

42 Cf. Neroni, Hilary, op. cit., 2005, p. 25.

43 Se, no cinema norte-americano, a violência feminina estava concentrada nos noir, o mesmo não pode ser dito da violência masculina. $\mathrm{O}$ vínculo entre masculinidade e violência aparecia em diversos tipos de narrativas fílmicas, propondo outras associações. De acordo com Neroni, "os westerns mostravam homens usando a violência para levar a lei e a civilização para os fora-da-lei, enquanto conquistavam partes indomadas do país. Filmes de gangsters mostravam como a honra e a masculinidade emergiam quando alguém se provava violento. De forma similar - ainda que menos frequente - os filmes de guerra deste período conectavam claramente honra e respeitabilidade com a administração profissional do tipo de violência que exterminaria o inimigo e salvaria vidas norte-americanas". Neroni, Hilary, op. cit., 2005, p. 20; grifos meus. 
partir dos noir que uma nova síntese entre a virgem e a vamp começa a processar-se, dando origem à moça-boa-má, que terá, a partir dos anos 1950, os personagens interpretados por Marilyn Monroe e Brigitte Bardot como seus maiores expoentes:

a good-bad-girl possui um sex-appeal igual ao da vamp, na medida em que se apresenta como mulher impura: roupas leves, atitudes ousadas e carregadas de insinuações, subentendidos, relações suspeitas. Mas o fim do filme nos revelará que ela escondia todas as virtudes da virgem: alma pura, bondade inata, coração generoso ${ }^{44}$.

Assim, enquanto as características sensuais das primeiras femme fatales foram associadas a outros tipos de personagens femininos na tela, a mulher dotada de desejo sexual permaneceu, no imaginário, como uma mulher dominadora e cruel, voraz e insaciável. No entanto, escreve Christopher Lasch no fim da década de 1970, "antes fonte de deliciosa excitação, de gratificação sadomasoquista colorida de fascinação horrorizada, ela agora inspira aversão e receio inequívocos" ${ }^{45}$. A mesma reação parece ser despertada pela louca, um tipo de personagem feminino que, segundo Molly Haskell, surgiu durante a década de 1980, como expressão de uma mistura de desvios. Através dela foram apresentadas neuróticas, assassinas, libertinas, punks e desajustadas em geral, cujas construções utilizam-se também de certos atributos presentes nas mulheres fatais e nas vamps ${ }^{46}$. Personagens como Thana de Sedução e Vingança e Alex Forrest de Atração Fatal (Fatal Attraction, Adrian Lyne, 1987) reelaboram o perigo escondido sob a sexualidade feminina, mostrando o que uma mulher fora de controle pode fazer.

Entre o surgimento da moça-boa-má e da louca, a relação entre sexo e violência foi amplamente explorada por várias vertentes do paracinema ${ }^{47}$. Personagens femininos

44 Morin, Edgar, As estrelas, op. cit., 1989, p. 15; grifos do autor.

45 Lasch, Christopher, A cultura do narcisismo, op. cit., 1983, p. 247.

46 Cf. Haskell, Molly, From Reverence to Rape, op. cit., 1987, p. 373.

47 Também denominado cinema extremo ou de exploração (exploitation). Segundo Paulo Cesar Almeida Scarpa, o paracinema caracteriza-se pela produção de filmes com orçamento baixo, de distribuição precária, que exploram temáticas "transgressoras" ou incomuns ao cinema comercial, apresentando grande quantidade de violência explícita, cujo principal foco não está no desenvolvimento de uma trama, mas sim na criação de um efeito de choque no público. No geral, os filmes do paracinema são considerados de "mau gosto". Cf. Scarpa, Paulo Cesar Almeida. Transgressão, mercado e distinção: a violência extrema no cinema. Curitiba: Universidade Federal do Paraná, Dissertação (Mestrado), 2007 , p. 5. Entre as principais "vertentes" do paracinema que apresentaram mulheres violentas durante os anos 1960 e 1970, destacam-se: blaxpoitation (filmes que apresentam temas estereotipados da vida afro-norte-americana, como guetos, criminalidade, drogas e prostituição), rape-revenge (filmes em 
violentos emergem das mais diversas situações abordadas na tela: estupro, incesto, mutilação física, tortura, discriminação. Sem dúvida a ideia da retaliação ao abuso, qualquer que fosse, orienta a ação dos personagens femininos em muitas dessas narrativas. Nesse sentido, se o paracinema constituiu-se historicamente como o lugar da exploração estética e econômica dos interditos sociais, foi através de muitas de suas narrativas que personagens femininos começaram a ser vistos transformando-se de vítimas em algozes.

Neroni afirma que as primeiras aparições do que ela chama de mulher violenta “contemporânea" aconteceram nos blaxpoitation produzidos entre 1973 e 1975, filmes que "exploravam com impunidade a figura da heroína violenta" 48 . Isto acontece porque, em filmes como Cleópatra Jones (Cleopatra Jones, Jack Starrett, 1973) e Foxy Brown (Jack Hill, 1974), suas protagonistas se colocam ao lado da lei ${ }^{49}$. A ação da polícia, dessa maneira, não aparece como uma ameaça à justiça que elas encarnam. $\mathrm{O}$ mesmo não acontece com os protagonistas masculinos de narrativas do mesmo tipo que, não raro, apresentavam-se como foras-da-lei que disputam a liderança sobre um território com outros personagens.

Para esta autora, as protagonistas dos blaxpoitation têm como principais atributos a independência ${ }^{50}$, a agressividade e a inteligência. Compartilham com a femme fatale dos noir a beleza que, ao ser uma das armas utilizadas pelo personagem

que uma ou mais mulheres violentadas "caçam" os estupradores), shock exploitation (filmes cujo efeito de choque sobre o público aparece em sua forma mais radical), women-in-prison ou WIP (filmes que apresentam o tema da violência física e sexual no interior de prisões femininas), slasher (filmes que constroem massacres a partir da figura de um "assassino lunático" [psychokiller] que corta suas vítimas em pedaços até que é finalmente vencido ou morto pelo único sobrevivente da narrativa, não raro, uma mulher; importante notar que, apesar de também ser considerado como um tipo de filme de "mau gosto", nem todo slasher é exploitation). Cf. Clover, Carol J., Men, women, and chain saws, op. cit., 1992, p. 21; Neroni, Hilary, The violent woman, op. cit., 2005, p. 31; Scarpa, Paulo Cesar Almeida, Transgressão, mercado e distinção, op. cit., 2007, p. 40 e p. 42.

48 Neroni, Hilary, The violent woman, op. cit., 2005, p. 28. A problematização do termo contemporânea pelo uso das aspas, em Neroni, advém de uma percepção das permanências de uma narratividade da violência que torna impossível compreender o feminino como uma identidade que inclui a violência e o masculino como uma identidade que a exclui. A figura de uma mulher violenta será, de acordo com seus termos, causadora de um trauma que pode ser acessado tanto pelas ambiguidades presentes em filmes que trazem tais figuras, quanto pela opinião pública sobre tais filmes e sobre homicídios cometidos por mulheres.

49 Mesmo quando não trabalham para a lei, como acontece com o personagem de Foxy Brown.

50 A independência feminina, para Neroni, parece confundir-se com uma vontade própria. Neste sentido, caracteriza-se pela recusa de padrões de comportamento socialmente esperados para as mulheres. Isto acontece tanto no caso das heroínas dos serial queen melodramas, que buscam aventuras que a maioria das mulheres não buscariam na época, quanto no caso das heroínas dos blaxpoitation, que fazem o mesmo ao tomar a justiça para si - algo que nestas narrativas só acontece pela ausência de proteção masculina: suas protagonistas surgem como personagens violentos e independentes ao serem forçados pelas circunstâncias, que geralmente envolvem a morte ou desaparecimento daquele ou daqueles que deveriam protegê-la. 
para alcançar seus objetivos, é mantida mesmo durante os atos de violência ${ }^{51}$. Contudo,

sua violência é muito mais física e sangrenta que a da femme fatale. Ela usa armas de fogo ocasionalmente, mas estas não são as únicas armas que são colocadas ao seu dispor. Com frequência, ela aparece em combates corpo-acorpo em que bate mais que apanha. (...) E, diferente de qualquer femme fatale, as heroínas dos blaxpoitation sempre sobrevivem e quase sempre triunfam na sua busca por justiça ${ }^{52}$.

É certo que muitos dos elementos presentes nas justiceiras dos blaxpoitation como as prefiro chamar - estão também presentes nas formas como alguns personagens femininos violentos são apresentados na contemporaneidade, como a possibilidade de luta corpo-a-corpo, a preservação da "aparência feminina" através de caracterizações fortemente sexualizadas, a necessidade de uma justificação para a manifestação da violência - que aparece geralmente atrelada a uma ideia de retaliação - e a legitimação da violência pela sobrevivência do personagem nos desfechos das narrativas. Estes elementos, entretanto, não eram exclusividades das justiceiras dos blaxpoitation, tendo aparecido também em muitas outras narrativas do período, como as já mencionadas $A$ vingança de Jennifer e Ato de Vingança.

Numa chave um pouco diferente, mas também durante a década de 1970, a violência feminina aparece em filmes como O Massacre da Serra Elétrica (The Texas Chain Saw Massacre, Tobe Hooper, 1974) e Halloween (John Carpenter, 1978), através de um tipo de personagem que Carol J. Clover chamou de final girl (garota final ${ }^{53}$. Como as justiceiras, a final girl é parte vítima, parte heroína ${ }^{54}$. De acordo com Clover, a final girl

51 Cf. Neroni, Hilary, op. cit., 2005, p. 29. Segundo Neroni, a beleza da femme fatale era mantida durante seus atos de violência pelo uso de armas de fogo. Diz ela: "Esta arma fria, polida, fálica é o acessório perfeito para a femme fatale; ela tanto serve a sua apresentação altamente estilizada quanto ao seu comportamento insensível. A prevalência da arma, entretanto, também revela que estes filmes não podiam conceber que uma mulher (...) fosse forte o suficiente para fazer algo mais que puxar um gatilho. Ela também permite que a femme fatale continue a parecer bonita quando é violenta. Ela não precisa suar, gemer, fazer movimentos estranhos, e mesmo desalinhar seu cabelo enquanto mata alguém. Portanto, sua violência não perturba completamente as categorias tradicionais de gênero; ao contrário, deixa muito de sua feminilidade intacta". Neroni, Hilary, op. cit., 2005, p. 26; grifos meus.

52 Neroni, Hilary, op. cit., 2005, p. 30; grifos meus nas palavras em língua estrangeira, demais grifos da autora.

53 Assim como acontece com a vamp, manteve-se a expressão em língua inglesa devido à ausência de tradução corrente na bibliografia em português.

54 Cf. Clover, Carol J., Men, women, and chain saws, op. cit., 1992, p. 4. 
é quem encontra os corpos mutilados de seus amigos e quem percebe, de forma completa, a extensão do horror e do perigo em que se encontra; ela é quem é caçada, encurralada, ferida; a quem vemos gritar, comover, cair, levantar, e, novamente, gritar. Ela é a personificação de um terror desprezível, abjeto. Se seus amigos sabiam que estavam prestes a morrer poucos segundos antes do evento, a final girl vive com este conhecimento por longos minutos ou horas. Ela encara a morte sozinha, mas é também sozinha que encontra forças para ou manter-se a salvo do assassino tempo bastante para ser salva (desfecho A) ou matá-lo (desfecho B). Em qualquer um dos casos, a partir de 1974, a figura do sobrevivente é feminina ${ }^{55}$.

Em comparação com os outros personagens femininos destas narrativas, Clover sustenta que muitas final girls lembram meninos. Assim, ainda que bela,

ela não é completamente feminina - não da maneira como suas amigas o são. Sua esperteza, sua seriedade, sua habilidade em lidar com aparatos mecânicos, sua praticidade e sua falta de desejo sexual a distanciam das outras garotas e a aproximam, ironicamente, dos garotos que ela rejeita ou teme, para não falar do próprio assassino ${ }^{56}$.

Os personagens que surgiram na década de 1970, mais que serem os primeiros representantes do tipo de personagem que viria a aparecer durante os anos 1990 e 2000, criaram as condições para o seu surgimento. Eles acirraram as contradições que emergem, em primeiro lugar, da associação entre violência e maldade que se realiza através da figura da femme fatale e suas derivações e, por outro, da associação entre violência e loucura que se realiza através da figura da louca. É a partir da permanência e da ausência de atributos de cada um desses tipos de personagens - a femme fatale, a louca, a justiceira e a final girl - que o novo padrão de exercício da violência feminina começa a ser percebido nas telas do cinema.

Assim, se o personagem de Thana pode ser considerado como pertencente ao tipo proposto por Haskell, o mesmo não pode ser dito a respeito do de Erica. Durante o lapso de tempo marcado pelo aparecimento de um e outro personagem, o cinema vem construindo um novo tipo de personagem feminino, cuja principal característica

55 Clover, Carol J., op. cit., 1992, p. 35; grifos meus.

${ }^{56}$ Clover, Carol J., op. cit., 1992, p. 40. Talvez por isso Clover afirme que há um elemento de monstruosidade na parte heróica da final girl. 
distintiva é a possibilidade de ressignificação do feminino através de sua associação com a violência.

Tal ressignificação ancora-se, em primeiro lugar, em um uso mais amplo do corpo feminino como veículo de violência. Deste modo, o engajamento físico de personagens femininos em sequências de luta é muito mais frequente que anteriormente. Mesmo em um filme como Valente, em que sua protagonista não tem habilidades específicas de combate, ela não deixa de utilizar seu corpo como arma, como acontece na sequência em que assassina Murrow. Em segundo lugar, esta ressignificação estabelece-se por meio de um relativo ajustamento aos padrões de comportamento e de ação construídos pelas narrativas em que, personagens desse tipo, aparecem como protagonistas, ajustamento este que pode acabar por legitimar a violência feminina exercida na tela pela ausência de punição. $\mathrm{O}$ aparecimento deste tipo de personagem não implica, entretanto, que a punição à violência feminina tenha desaparecido das telas dos cinemas, nem que às protagonistas, como Erica, sejam destinados finais felizes, mas sim que passa a existir a possibilidade de, como acontece com ela, as assassinas deixarem de ser mortas, presas ou internadas no desfecho das narrativas. No entanto, esta é uma característica que pouco tem chamado a atenção de pesquisadores sobre o tema, talvez porque não seja, exatamente, uma completa novidade, já que o mesmo acontecia com as justiceiras do início da década de 1970. A diferença aqui é que não apenas personagens que se apresentam ao lado da lei parecem ajustadas aos padrões de legitimação da violência no interior das narrativas em que aparecem, mas também aqueles personagens que antes eram construídos em profundo desajuste com eles. Desta forma, os filmes interpretados neste trabalho revelam que já não é tão simples identificar qual a imagem da mulher mais ajustada ao contexto da narrativa, porque ela não aparece simplesmente como sendo boa ou má, como dentro ou fora-da-lei, como louca ou sã e, assim, outros atributos e características são necessários para a construção desses sentidos de ajustamento.

\section{A FEMINILIDADE DA VIOLÊNCIA}

Qualquer trabalho que se ocupe da violência feminina no cinema "encara" o problema da permanência, no imaginário, da associação entre violência e 
masculinidade ${ }^{57}$. Num nível mais imediato, esta permanência aparece como fundamento da própria necessidade de qualificação da violência como feminina. Se, hoje, a violência pode ser expressa, no cinema, por meio de formas relativamente indiferenciadas ${ }^{58}$, perguntar-se a respeito da especificidade da violência feminina apresenta-se como um desdobramento quase inevitável.

Um primeiro problema que surge a partir desta permanência é o "risco" de tomálo como pressuposto teórico-metodológico. Neroni afirma que "discussões teóricas sobre a masculinidade no cinema baseiam-se na pressuposição de que a violência é uma atividade masculina" ${ }^{, 59}$. Ora, Neroni - bem como outros autores -, tem o mesmo ponto de partida em relação à violência feminina. Ao considerar que, tradicionalmente, a violência aparece como um atributo do masculino, e uma vez que o feminino não compartilha com ele este atributo - constituindo-se, ao contrário, na sua negação -, expressões de violência feminina são frequentemente concebidas como desvio ou como transgressão dos papéis tradicionais de gênero. O que se coloca em jogo a partir daí já não são mais os possíveis significados da violência no cinema - tida como mera expressão de um poder que se torna, por definição, masculino, mesmo quando "apropriado" por uma mulher - mas os significados de um discurso de gênero que se reitera e se questiona por meio do espetáculo da violência. Neste sentido, a maneira como a violência se realiza na tela converte-se em evidência - e, não raro, em reflexo das contradições relativas à dominação de gênero e das tensões que se originam das profundas transformações socioculturais que se processaram no último século em relação aos homens e às mulheres, especialmente após a década de 1960.

No que se refere especificamente às assassinas, Lucy Fischer argumentou, no fim dos anos 1980, que a mulher que mata seria "considerada mais perversa que $o$ homem, porque ela viola a imagem da mulher que dá a vida e zela por seu desenvolvimento - figuras que a ele não se aplicam" ${ }^{, 60}$. Mais recentemente, Neal King e

57 Tal associação remonta à própria origem da palavra violência. De acordo com Marilena Chauí, "os verbos (violentar e violar), o adjetivo (violento) e o substantivo (violência) derivam todos da mesma palavra latina vis, que significa força, particularmente a força exercida contra alguém (donde violência e violação); no plural, vis designa as partes sexuais do homem, as forças militares e, por extensão, as tropas. (...) Por sua origem na palavra latina vis, força, a violência possui um significado sexual afirmativo para os homens, mas assume sentido negativo quando essa força sexual se volta contra as mulheres (estuprar, deflorar)". Chauí, Marilena. Simulacro e poder: uma análise da mídia. São Paulo: Editora Fundação Perseu Abramo, 2006, pp. 117-118; grifos da autora.

58 Difícil aqui não lembrar da similaridade com que os movimentos de Neo e Trinity são construídos em Matrix (The Matrix, Andy Wachowski e Lana Wachowski, 1999).

59 Neroni, Hilary, The violent woman, op. cit., 2005, p. 46.

60 Fischer, Lucy. "Murder, She Wrote: Women Who Kill". In: Shot/Countershot - Film 
Martha McCaughey defenderam que, independente de serem vilãs mal-intencionadas ou defensoras da humanidade ou da justiça, personagens femininos violentos aparecem como mulheres malvadas, porque

em quase todos os casos, alguém implicará que tal ação [violenta], porque realizada por uma mulher, apresenta-se abaixo dos padrões de decência humana. (...) Para muitas pessoas, as apresentações de violência feminina parecem mais terríveis, talvez porque encontramos muito mais cenas de violência cometidas por homens que por mulheres. Além disso, os padrões culturais ainda identificam feminilidade à gentileza e à não-violência e a masculinidade à força e à agressão ${ }^{61}$.

Por um lado, estes argumentos mostram a força da associação entre violência feminina e maldade no imaginário cinematográfico, consolidada a partir da figura da femme fatale e amplificada pelos vários papéis assumidos pela louca. Por outro, os argumentos de Fischer, Neal e McCaughey mostram que, se a maldade ou a crueldade que parecem nada mais do que formas de perversão - são capazes de ser o fundamento do estabelecimento de uma hierarquia em relação à violência ${ }^{62}$, ela não aparece, no discurso sobre a violência feminina no cinema, primordialmente em referência às outras mulheres apresentadas em uma narrativa ou em um conjunto delas, mas em relação ao homem, concebido como categoria abstrata e difusa, significante das relações de dominação de gênero. Qualquer diferença nas maneiras como a violência feminina constrói-se pelo cinema desaparece frente à força do pressuposto que reitera - e não questiona - as construções sociais que permitem afirmar que, em primeiro lugar, a violência é masculina e que expressa, necessariamente, virilidade; em segundo lugar, que se uma mulher é violenta, ela não é de fato feminina e, portanto, há algo de "errado" com ela. Com base neste pressuposto, qualquer que seja a maneira como a violência feminina é construída no cinema, ela tende a ser considerada primordialmente como desvio $^{63}$.

Tradition and Women's Cinema. Princeton, NJ: Princeton University Press, 1989, p. 269; grifos meus.

61 King, Neal; McCaughey, Martha, "What's a mean woman like you doing in a movie like this?", op. cit., 2001, p. 2; grifos meus.

62 Algo que também opera na construção da violência masculina.

63 Tal como problematizam Elizabeth Hills e Jeffrey A. Brown. A este respeito ver: Hills, Elizabeth. "From 'figurative males' to action heroines: further thoughts on active women in cinema". In: Screen, 40 (1), 1999, pp. 38-50; Brown, Jeffrey A. "Gender, Sexuality and Toughness: The Bad Girls of Action Film and Comic Books". In: Inness, Sherrie A. Action chicks: new images of tough women in 
Ao conceber a violência feminina como um desvio, indaga-se como e em que medida a associação entre a violência e a imagem feminina redunda numa masculinização da figura da mulher no cinema, ou seja, numa descaracterização do feminino. A masculinização da figura feminina por intermédio da violência não concerne apenas os personagens cuja caracterização remete a uma estética masculina, mas também, e principalmente, à mulher fálica. Tais personagens não necessariamente tornam-se esteticamente masculinizados - basta lembrar o que acontece com Thana, justamente o contrário -, mas a maneira como seus comportamentos e ações são construídos sugeririam, então, que tais mulheres transformam-se, no plano simbólico, em expressões do masculino. Em última instância é a isso que remete a noção de mulher fálica, àquela que toma o lugar do homem e que o converte, simbolicamente, em mulher. Ora, tal concepção não deixa de refletir o modelo de complementaridade dos gêneros em relação à violência, que aparece, como num espelho, de forma invertida. Nesta configuração, a violência será sempre equiparada a um poder bastante específico, que é de determinar quem - independente do sexo "original" - ocupa o lugar do gênero masculino no plano simbólico. Apesar de seus limites, uma abordagem nesta direção mantém profunda relação com um certo "momento" do cinema em que elementos fálicos eram predominantemente utilizados na construção das imagens da violência feminina. É apenas quando surgem personagens que problematizam estas construções através de suas contradições e inovações - como Ellen Ripley, de Alien - que uma discussão em torno do potencial transgressor de personagens femininos violentos ganha força.

Não deixa de ser interessante que Alien seja considerado um marco do surgimento do novo padrão de exercício da violência feminina no cinema porque, nele, Ripley nada mais faz que conseguir esquivar-se da criatura até, finalmente, conseguir lançá-la no espaço. A bordo da nave Nostromo, que aparece como espaço primordial do filme lançado em 1979, há duas mulheres: Ellen Ripley e Lambert. Ao darem-se conta que tiveram seu percurso modificado pelo comando central, em virtude da possibilidade da descoberta de uma outra forma de vida em um planeta situado na metade do caminho para a Terra, grande parte da tripulação incomoda-se, por diferentes razões, com a nova missão. Parece haver um anseio geral pelo retorno ao planeta natal, contudo, Lambert é o personagem que se mostra mais nervoso com a incumbência. Vista fumando na cabine 
de comando, enquanto Kane ${ }^{64}$ conversa com o capitão do cargueiro, Dallas, sobre a possibilidade de alcançarem a pé o ponto de onde se origina o sinal capitado pela navemãe depois do Nostromo ter sido avariado durante o pouso no planeta, seu desconforto com a situação é aparente, o que é corroborado pela sua reação quando Dallas lhe informa que integrará a primeira equipe de investigação. Acompanhando Kane e Dallas até o ninho alienígena, Lambert ora reclama ora insiste para que regressem à nave. Lambert é construída, portanto, primordialmente, na chave do medo. Sua caracterização se aproxima e se distancia da caracterização de Ripley. Segunda no comando da espaçonave, Ripley mostra-se capaz de interpretar o sinal emitido desde o ninho como um sinal de alerta e, apesar de suas ações não serem suficientes para impedir que Kane seja contaminado e levado de volta ao Nostromo, o que coloca a todos em perigo, o comportamento de Ripley é mais facilmente identificado ao zelo e ao cuidado do que ao temor. Se, inicialmente, Lambert parece ser aquela que se dá conta da dimensão da ameaça que a nova missão anuncia, o que a habilitaria para ocupar a posição da final girl na história, seu descontrole emocional anuncia sua queda, o que não tarda em acontecer. Deste modo, a emotividade tradicionalmente associada aos personagens femininos aparece desvalorizada por meio de Lambert. Evidencia-se, deste modo, que o ajustamento da figura feminina à história baseia-se em outras características, como o controle de si que aparece por meio da figura de Ripley. Entretanto, são os personagens femininos que são vistos gritando apavorados quando em face da criatura e, neste sentido, a narrativa também favorece uma identificação plena da figura feminina como vítima quando mostra, primeiro, a criatura que se desprendera misteriosamente do rosto de Kane cair sobre Ripley e, depois, quando este personagem explode ao "dar a luz" ao filhote do monstro, Lambert é vista sendo coberta por seu sangue. Em contrapartida, os personagens masculinos morrem, em sua maioria, em silêncio, não porque enfrentam o monstro com bravura, mas simplesmente porque desaparecem antes que possam ser vistos gritar. Não há, neste sentido, uma desestabilização da maneira como tradicionalmente constrói-se a relação entre o masculino e a violência, nem uma aproximação das figuras masculinas presentes no filme com os aspectos "femininos" do papel de vítima.

O furor causado pelo aparecimento de Ripley deve-se, então, tanto ao fato de ela levar a figura da final girl a um cinema de mainstream ${ }^{65}$, quanto da combinação de

64 Personagem que se tornará hospedeiro do monstro no interior do Nostromo.

65 Comparado a um filme como Halloween as diferenças orçamentárias são impressionantes. Enquanto 
atributos tidos como exclusivamente masculinos ou femininos presente em sua caracterização. Em torno de sua figura há tanto interpretações que a identificam a um personagem masculinizado, quanto a identificam à construção de uma nova subjetividade feminina, produzida por um corpo ativo e criativo, sede de uma série de competências e habilidades (inclusive em relação ao uso de tecnologias). Nesta direção, seu caráter transgressor residiria justamente na construção de um corpo dotado de uma subjetividade feminina diferenciada, à qual o espectador não teria nenhuma referência imediata de leitura $^{66}$. De acordo com minha interpretação, contudo, Ripley, assim como outros personagens do mesmo tipo, tem nas imagens dos contornos do corpo sua fonte de identificação primeira com o feminino. Tal identificação é o que garante que tais personagens não figurem como masculinizados ${ }^{67}$. Se há um potencial transgressor nestas caracterizações, ele advém da combinação entre um corpo feminino reconhecível e a construção de uma subjetividade baseada na ação.

A diferença última entre esta concepção (da transgressão) e a primeira (do desvio) perpassa o reconhecimento de que, como resultado, se tem uma imagem de mulher, não de sua negação. Entretanto, como defende Neroni, as contradições presentes na combinação de atributos femininos e masculinos, que aparece em uma série de personagens femininos durante as últimas décadas, pode tanto reiterar antigas distinções de gênero quanto colocá-las à prova. De acordo com ela, isto decorre de uma inabilidade em se conceber a masculinidade como uma identidade que exclui a violência e a feminilidade como uma identidade que a inclui ${ }^{68}$.

É claro que o cinema construiu, durante sua história, uma iconografia da violência alicerçada fundamentalmente sobre o masculino, utilizando-se de símbolos que identificam falo e poder, mesmo quando, por vezes, apresenta atos violentos sendo cometidos por mulheres. Do mesmo modo, também é certo que todos os tipos de personagens femininos abordados no início deste capítulo mantêm entre si a

Halloween teve um orçamento de trezentos e cinquenta mil dólares, Alien teve um orçamento de onze milhões. Cf. "Halloween". In: Box Office Mojo, disponível em URL em: http://www. boxofficemojo.com/movies/?id=halloween.htm, acessado em 30/08/2010 e; "Alien”. In: Box Office Mojo, disponível em: http://www.boxofficemojo.com/movies/?id=alien.htm, acessado em 30/08/2010.

66 Cf. Hills, Elizabeth, "From 'figurative males' to action heroines: further thoughts on active women in cinema", op. cit., 1999, pp. 38-44.

67 Neste sentido, Ripley apresenta-se como a figura feminina mais ajustada também no segundo filme da série, Aliens (James Cameron, 1986) pela contraposição com a soldado Vasquez, cuja aparência é bastante masculinizada pelo figurino, porte físico e comportamento. Aliens é um filme importante porque reitera a construção de Ripley como um personagem não-masculinizado. Superada uma possível identificação de Ripley como uma figuração do masculino, ela aparece como o único personagem feminino em ação em Alien 3 (Alien ${ }^{3}$, David Fincher, 1992).

68 Cf. Neroni, Hilary, The violent woman, op. cit., 2005, p. 161. 
característica de serem construídos em referência a um ideal ou desejo masculino. De acordo com John Berger, ao analisar como a imagem da mulher foi construída a partir da tradição europeia,

a mulher é representada de uma maneira bastante diferente do homem - não porque o feminino é diferente do masculino - mas porque se presume que o espectador "ideal" é masculino, e a imagem da mulher tem como objetivo agradá-10 ${ }^{69}$.

Nos termos de Berger, o modo como o corpo da mulher é apresentado tem o intuito de apelar à sexualidade masculina, nada tendo a ver com sua própria sexualidade: "a mulher está ali para alimentar um apetite, não para ter um apetite próprio" .

Como apontam Neal e McCaughney, o argumento de que "a imagem feminina carrega, no cinema, as marcas de suas origens patriarcal, heteronormativa e hegemonicamente branca" ${ }^{, 71}$ não apresenta em si novidade alguma. Além disso, essa não é uma prerrogativa exclusiva da imagem feminina, podendo-se dizer o mesmo a respeito da imagem masculina ${ }^{72}$. No entanto, ao alimentar este apetite, o cinema colabora na construção de imaginários relativos $\grave{a}(s)$ sexualidade(s) feminina(s) e, por conseguinte, ao próprio feminino, que se torna primeiramente reconhecível, e finalmente reiterado, através de planos que revelam a presença de seios e das curvas dos quadris.

Judith Butler alerta que, se por um lado, as diferenças sexuais não podem ser separadas das demarcações discursivas, por outro, isto não significa que essas diferenças originam-se do discurso. Há uma dimensão normativa fundamental na categoria "sexo", de modo que ele não apenas funciona como norma, mas é parte de uma prática cuja força apresenta-se claramente como um tipo produtivo de poder, que fabrica, demarca, circula e diferencia os corpos que controla ${ }^{73}$.

Em outras palavras, o "sexo" é um construto ideal cuja materialização é

69 Berger, John. Modos de Ver. Rio de Janeiro: Rocco, 1999, p. 66.

70 Berger, John, op. cit., 1999, p. 57.

71 King, Neal; McCaughey, Martha, “What's a mean woman like you doing in a movie like this?”, op. cit., 2001, p. 3.

72 E, com algumas variações, a respeito das imagens da própria história. A este respeito, ver: Shohat, Ella; Stam, Robert. Crítica da imagem eurocêntrica. São Paulo: Cosac Naify, 2006.

73 Cf. Butler, Judith. Bodies that matter: on the discursive limits of "sex". Nova Iorque, Londres: Routledge, 1993, p. 1. 
imposta através do tempo. Não é um fato simples ou uma condição estática de um corpo, mas um processo através do qual as normas reguladoras materializam o "sexo" por meio da sua reiterada imposição. Que esta reiteração faz-se necessária é um sinal de que a materialização nunca é inteiramente completa, que os corpos nunca acedem totalmente às normas que estimulam sua materialização. (...) O "sexo" não é, então, simplesmente aquilo que uma pessoa tem, ou uma descrição estática do que alguém é: será uma das normas pelas quais esse "alguém" torna-se viável, o que qualifica o corpo para a vida no interior de um domínio de inteligibilidade cultural ${ }^{74}$.

Para Butler, portanto, na raiz do processo da materialização da sexualidade (a partir da qual se acessa a própria materialidade das relações de gênero) está o processo de formação de um "eu", de uma identidade, que perpassa uma discussão "dos meios discursivos através dos quais o imperativo heterossexual permite certas identificações e impede e/ou nega outras",75. Ao fabricar um domínio do sujeito que se baseia na exclusão de identificações, o processo de materialização do sexo fabrica também um domínio do abjeto, daqueles que ainda não são sujeitos de um discurso, situados que estão do lado de fora da fronteira do sujeito ${ }^{76}$.

$\mathrm{O}$ abjeto designa, neste sentido, precisamente aquelas zonas desertas ou inabitáveis da vida social, densamente povoadas por aqueles que não gozam de um status de sujeito, mas que são necessários para a circunscrição de seus domínios. Esta zona inabitável constituirá o limite definidor do domínio do sujeito, constituirá o lugar da temida identificação contra a qual - e em virtude da qual - o domínio do sujeito circunscreverá sua defesa de autonomia e vida. (...) Assim, a materialização de um dado sexo concerne principalmente à regulação de práticas identificatórias, de modo que a identificação com a abjeção do sexo será persistentemente negada ${ }^{77}$,

pois uma identificação com o abjeto ameaça expor as bases que fundamentam o sujeito sexuado. De acordo com a autora, o desafio frente a esta ameaça ou possibilidade de ruptura é considerá-la como "um recurso crítico no esforço de rearticulação dos termos

74 Butler, Judith, op. cit., 1993, pp 1-2.

75 Butler, Judith, op. cit., 1993, p. 3.

76 Cf. Butler, Judith, op. cit., 1992, p. 2-3.

77 Butler, Judith, op. cit., 1993, p. 3; grifos meus nas palavras em língua estrangeira, demais grifos da autora. 
de uma legitimidade e inteligibilidade simbólicas",78.

Num "momento" em que se debruça sobre uma possível rearticulação destes termos em relação à associação da violência com o feminino, é possível conceber a violência como um elemento que se situa na fronteira entre os domínios do abjeto e do sujeito deste sexo. Isto significa dizer que, para além de ser um elemento de distinção entre os sexos, a violência assumiu um lugar de diferenciação entre possíveis identidades femininas. A disputa discursiva em torno dos atributos de gênero é entendida, então, como parte de um processo normativo e histórico que perpassa a fabricação de diferentes subjetividades no interior do domínio de um mesmo sexo.

Neste sentido, a violência feminina é desvio e transgressão apenas num plano geral. Em primeiro plano, e em relação ao que se entendeu tradicionalmente como feminino, a mulher violenta apresenta-se como estranha. Esta é sua especificidade. Através dela, a violência que é excluída pelo processo de docilização de seu corpo retorna, de modo que ela constrói-se como um outro-feminino ${ }^{79}$. Os outros-femininos que interessam aqui não são aqueles da loucura, tampouco os da maldade - outros, portanto, que localizam a violência feminina no domínio do abjeto -, mas aqueles que combatem a ambos ao mesmo tempo em que se relacionam intimamente com o seu próprio outro: o feminino da doçura (e, em termos muito gerais, o do melodrama). A guerreira, como chamo o tipo de personagem que expressa esta disputa discursiva em torno da legitimidade e inteligibilidade de diferentes identidades femininas, apresentase, assim, como a manifestação mais contemporânea da elaboração simbólica deste estranhamento. A guerra que ela trava é, portanto, com diferentes imaginários sobre as mulheres, uma guerra que, como todas as outras, se ganha antes no imaginário que no campo de batalha, porque, como lembra Paul Virilio, "abater o adversário é menos capturá-lo do que cativá-lo, é infligir, antes da morte, o pânico da morte (...) 'A força das armas não é uma força brutal, mas uma força espiritual" "80.

78 Butler, Judith, op. cit., 1993, p. 3.

79 Incorporo aqui não apenas as concepções acerca do estranho de Sigmund Freud - a este respeito ver nota 89 do Capítulo I deste volume -, mas também a aproximação que faz Michel Foucault do Outro aquele que é "estranho à semelhança fraterna dos homens entre si”, com o Estrangeiro e o Excluído. Foucault, Michel. História da loucura. São Paulo: Perspectiva, 2003, p. 134; grifos meus. Sobre a produção de corpos dóceis, ver: Foucault, Michel. Vigiar e punir: nascimento da prisão. Petrópolis: Vozes, 1987 , p. 118 e p. 119 , e a discussão realizada no capítulo seguinte.

80 Virilio, Paul. "A força militar é determinada pela aparência”. In: Guerra e Cinema. São Paulo: Página Aberta, 1993, p. 12; citando Ortega y Gasset, cf. nota 2 da mesma página; grifos do autor. 
PARTe II:

VIOLÊNCIA E FEMININO NO CINEMA CONTEMPORÂNEO (1990-2004) 


\section{CAPÍtulo III - Nikita}

O fundo negro, em que se leem os nomes da produtora e do diretor de Nikita ${ }^{l}$ (Luc Besson, 1990) em letras vermelhas, abre-se para os paralelepípedos úmidos que brilham no centro da tela. Os nomes dos principais atores da trama aparecem, um de cada vez, à direita e à esquerda, também em letras vermelhas. A melodia sombria da abertura do filme ganha intensidade. A câmera que percorre os paralelepípedos abre-se novamente à frente, diminuindo seu ritmo ao encontrar os protagonistas dos acontecimentos daquela noite.

Lado a lado, quatro personagens marcham em meio à via ampla. O ritmo de seus passos parece acompanhar o das batidas da música. O que aparece do lado esquerdo da tela - de cabelos pelos ombros, costas nuas musculosas e calça escura presa por dois cintos, cujos detalhes em metal prateado brilham na escuridão - arrasta, pelo colarinho, uma jovem desacordada com a mão esquerda e segura um machado vermelho com a direita. Emoldurando o rosto da jovem, a parte de seu cabelo pintado de verde limão destaca-se na escuridão que quase engole o resto de seu corpo, vestido também por roupas escuras. Os demais aparecem ligeiramente a sua frente. Da esquerda para a direita da tela, o segundo exibe um sobretudo cinza esverdeado que cobre grande parte de seu corpo, mas deixa entrever a parte de sua perna descoberta entre a peça e o coturno. O terceiro, também de coturno, veste uma jaqueta escura, cujos punhos escondem suas mãos, e uma bermuda marrom. Os dois do centro têm cabelos curtos, cortados rente à nuca. $\mathrm{O}$ cabelo pintado de ruivo e em forma de capacete, a mão esquerda pequena que se vê desde o punho da jaqueta negra mais curta e acinturada, bem como a calça acinzentada mais ajustada ao corpo, sugerem que o quarto personagem seja uma mulher ${ }^{2}$. Pouco antes da câmera mostrá-los de frente, o nome do

1 O nome do filme recebeu, no Brasil, o subtítulo de Criada para Matar, indicando ao espectador uma possível leitura do filme que não se realiza, uma vez que Nikita já matava antes de ser obrigada a tornar-se agente da inteligência do Estado francês. O subtítulo em questão é bastante interessante, uma vez que através dele vê-se operar a necessidade de justificar-se a violência feminina, transformando-a não em algo que lhe é inerente, mas sim algo que se dá pelas circunstâncias. Nikita, contudo, é um dos raros filmes que trazem, de início, um personagem feminino violento sem que haja qualquer justificativa eficaz o suficiente para "explicar" seu comportamento.

2 Segundo Gilles Lipovetsky ainda que nas últimas décadas do século vinte tenha havido, na moda, uma redução da diferença enfática entre o masculino e o feminino - o que tornou a moda masculina menos austera e aumentou a utilização, em massa, de artigos originalmente masculinos pelas mulheres - "a moda não deixa de organizar signos diferenciais, por vezes menores, mas não inessenciais, num sistema que precisamente 'é o nada que faz tudo' (...) um simples detalhe basta para discriminar os 
filme sobrepõe-se à imagem em grandes letras vermelhas, ocupando toda a parte centrohorizontal da tela. Os nomes dos demais atores aparecem em seguida, na parte de baixo do écran.

De frente, a câmera, posicionada de baixo para cima, mostra-os mais de perto. Do lado esquerdo da tela, a mulher tem os cabelos mal arrumados, o olhar perdido e os lábios entreabertos. O personagem que caminha a seu lado tem os punhos cerrados e o olhar determinado. O terceiro, caminha com as mãos dentro dos bolsos de seu sobretudo e masca chiclete. Veem-se outros detalhes de seus figurinos, como a camisa xadrez e a jaqueta jeans do segundo e os detalhes da jaqueta da ruiva. O rosto e o peito suados e sujos do quarto exibem o esforço físico de arrastar a jovem e, quando a câmera os mostra novamente de costas, percebe-se que ele agora a arrasta do lado direito de seu corpo e empunha o machado com a mão esquerda. Em toda a sequência, quando a câmera se aproxima deles, os ruídos de seus passos, do tilintar dos cintos do personagem sem camisa e da jovem sendo arrastada são ouvidos pelo espectador. A câmera aproxima-se e afasta-se deles, até que os deixa alcançar seu destino e a música diminui novamente seu ritmo. O corpo da jovem desacordada é largado no chão, repousando parte sobre a calçada, parte sobre a sarjeta.

Pela maneira como aparecem os personagens nestes dois primeiros minutos de Nikita vários dos estereótipos associados à rebeldia e à delinquência juvenil podem ser percebidos. Segundo Helena Wendel Abramo, é a partir dos anos 1950 que a noção de uma cultura juvenil genérica e compartilhada pelos diferentes setores que compõem a juventude ${ }^{3}$ começa a ganhar corpo, sendo ancorada em grande medida nos conflitos familiares e na rebeldia ${ }^{4}$ :

neste período, os conflitos que atravessam a condição juvenil são percebidos

sexos. (...) Um pouco em toda parte, os artigos de moda reinscrevem, por intermédio de pequenos 'nadas', a linha divisória da aparência. É por isso que os cabelos curtos, as calças, paletós e botas não conseguiram de modo algum dessexualizar a mulher; são, antes, sempre adaptados à especificidade do feminino, reinterpretados em função da mulher e de sua diferença". Lipovetsky, Gilles. $O$ império do efêmero: a moda e seu destino nas sociedades modernas. São Paulo: Companhia das Letras, 1989, p. 131.

3 De acordo com Fernando Lima das Neves, a compreensão dos significados em torno da categoria juventude perpassa uma variedade de aspectos, como "classe social, sexo, idade, geração (as diferentes experiências de vida e a memória social incorporada) e a dinâmica dos círculos familiares", fazendo com que a juventude seja uma condição. Neves, Fernando Lima das. Nas encruzilhadas do "eu" e do "nós": juventude, auto-imagem e interação social numa pequena cidade. São Paulo: Programa de Pós-Graduação em Sociologia, FFLCH-USP, Dissertação (Mestrado), 2006, p. 15.

4 Cf. Abramo, Helena Wendel. Cenas Juvenis - Punks e Darks no Espetáculo Urbano. São Paulo: Scritta; Anpocs, 1994, pp. 27-28. 
como derivados das rupturas de padrões entre adultos e jovens. São, principalmente, conflitos de expectativas sobre o modo de integração dos jovens na vida adulta e sobre a condução da maneira de viver esta fase juvenil. A condição juvenil emerge então como uma fase centrada sobretudo na reivindicação de prazer e independência, da qual redundam graves conflitos com pais, professores e policiais, e que, muitas vezes, geram posturas de violência "descontrolada" e "sem direção".

De acordo com Claudia Springer, desde os tempos de James Dean, a rebeldia apresenta-se como um conceito vago, sinônimo de contestação de valores antagônicos sem que, necessariamente, haja engajamento político por parte dos jovens. Não raro, a rebeldia juvenil aparece associada à violência, sendo compreendida, então, como delinquência. Segundo Springer, o rebelde juvenil que aparece em narrativas diversas, desde aqueles anos, nem sempre se parece com Dean ou faz referência explícita a ele, mas carrega traços ou vestígios de sua influência ${ }^{6}$. Em Nikita, o figurino dos primeiros personagens vistos na tela e a presença do chiclete apresentam-se como vestígios dessa iconografia do jovem rebelde.

Gilles Lipovetsky afirma que as modas jovens, surgidas desde a segunda metade do século passado, buscaram, através da conquista de uma autonomia no parecer, uma ruptura radical com os códigos dominantes do gosto e da conveniência. Por meio deste parecer autônomo, os jovens exibem seu "afastamento radical com a média, arriscando a provocação, o excesso, a excentricidade, para desagradar, surpreender ou chocar""7. Dessa forma,
o parecer não é mais um signo estético de distinção suprema, uma marca de excelência individual, mas tornou-se um símbolo total que designa uma faixa de idade, valores existenciais, um estilo de vida deslocado, uma cultura em ruptura, uma forma de contestação social ${ }^{8}$.

Neste sentido, a proposição da rebeldia juvenil é reforçada, no filme, pela mescla de

\footnotetext{
Abramo, Helena Wendel, op. cit., 1994, p. 34.

6 Cf. Springer, Claudia. James Dean Transfigured: the many faces of rebel iconography. Austin: University of Texas Press, 2007, p. 16-7.

7 Lipovetsky, Gilles, O império do efêmero, op. cit., 1989, p. 126.

8 Lipovestky, Gilles, op. cit., 1989, p. 127
} 
referências a diferentes subculturas juvenis ${ }^{9}$ e suas modas - pelos longos cabelos, bracelete e metais nos cintos do personagem que arrasta a jovem, cuja aparência associasse-se, assim, ao rock pesado dos anos 1970, e, pelos cabelos pintados com cores vibrantes da jovem que é arrastada e os coturnos dos três outros, cuja caracterização relaciona-se ao movimento punk do fim dos anos 1970 e da década de 1980. Assim, a narrativa utiliza-se de diferentes estéticas surgidas no interior de subculturas juvenis para criar seu estereótipo de jovem delinquente. Além disso, o uso de bermudas - uma peça que, tradicionalmente, era usada por meninos - pode ser interpretado como indício de uma possível negação da vida adulta. Na sequência, contudo, é o conjunto formado pela presença da jovem sendo arrastada e do machado que sugere que esse grupo de personagens é violento.

A sequência posterior confirma este direcionamento. Ao chegarem à farmácia, um deles saca um molho de chaves e começa a procurar aquela que abre o cadeado da porta. Ele tem um jogo da velha desenhado na cabeça pelo cabelo quase completamente raspado $^{10}$. O personagem de sobretudo se impacienta e sinaliza para que o de cabelos compridos arrombe a porta com o machado. Obedecendo, ele a arrebenta. Aquele que tem as chaves reclama, dizendo que o lugar é seu e que não precisavam arrombá-lo. Ele faz um jogo de palavras com o apelido do jovem de cabelos compridos, Zap ${ }^{11}$. Destruir é o que ele sabe fazer. O personagem de sobretudo insiste para que entrem e a ruiva lhe diz que precisa de uma dose. Vê-se que ela traz fones nos ouvidos ${ }^{12}$. Ele responde, com os olhos vidrados, que conseguirá o que ela precisa. O diálogo do casal informa, portanto, que os integrantes do grupo fazem uso de drogas, apresentando dessa maneira

9 A problematização da noção de uma cultura juvenil genérica, durante a década de 1970, a partir da consideração das origens de classe dos grupos juvenis estudados naquele período, fez com que seu surgimento e atuação fossem reinterpretados como subculturas juvenis: "modos de elaboração e projeção de respostas culturais aos problemas colocados pela especificidade do grupo no interior da classe de origem". Abramo, Helena Wendel, Cenas Juvenis, op. cit, 1994, p. 35.

10 Apesar de ser um jogo de regras bastante simples, existem mais de três centenas de milhares de possibilidades de se preencher o tabuleiro com os símbolos utilizados no jogo da velha. É interessante perceber que o desenho do jogo raspado na cabeça do personagem aparece pela primeira vez, e mais claramente, no momento em que ele procura a chave que abre o cadeado da farmácia, sem que ele consiga encontrar a correta antes que a porta seja arrombada. Além disso, a parte visível do desenho que ele traz na cabeça não aparenta ser de um jogo em que tenha havido um vencedor, o que poderia indicar o desfecho da invasão.

11 Do verbo francês zapper: destruir.

12 Aqui, os fones de ouvido aparecem como mais um elemento a compor a juventude proposta pela narrativa, uma vez que música figura como elemento centralizador das atividades e da elaboração das identidades de várias subculturas juvenis, desde a associação da juventude com o rock ' $n$ roll. Cf. Abramo, Helena Wendel, op. cit., 1994, p. 46. Além disso, a presença dos fones de ouvido colabora também para que o personagem de Nikita mantenha-se distanciado dos demais, numa postura ensimesmada perante os outros membros do grupo. 
uma justificativa para a invasão da farmácia.

Dentro do estabelecimento, suas faces aparecem sob um tom de azul intenso e sombrio, que reitera seu entorpecimento. Um corte nos leva ao dono da farmácia e a sua esposa, no quarto do casal situado no apartamento no andar superior do prédio. A luz neon verde do luminoso da farmácia entra pela janela do ambiente em que predominam vários tons de vermelho ${ }^{13}$. O homem chama a polícia pelo telefone, mas diz que não a esperará. E, enquanto carrega a espingarda, diz à mulher, que permanece recostada sobre a cama, muda, com um livro nas mãos e rolos nos cabelos, que fará com que eles parem de perturbá-los, o que sugere que a farmácia já fora invadida outras vezes de forma semelhante.

De volta ao estabelecimento, a jovem repete seu pedido, sentada embaixo do tampo do balcão. O jovem de sobretudo ordena que ela se acalme e, com o filho do dono do estabelecimento, Coyotte, passa a revirar as gavetas procurando por remédios. Desprezando as ações dos demais, Zap começa a experimentar óculos de sol. A jovem que ele carregara aparece sobre o chão. Neste ponto, o espectador já consegue perceber que o jovem de sobretudo comanda o grupo, que invadira a farmácia para roubar medicamentos para sua namorada. Zap aparece como um autômato, reagindo apenas quando comandado, completamente alheio e abobalhado. A luz do estabelecimento se acende e o pai de Coyotte não o reconhece de pronto. É o jovem de sobretudo que, enfrentando o senhor, entrega a presença do filho. Coyotte, que o pai chama de Antoine, diz a ele que precisam de drogas. De um lado, tem-se o jovem de sobretudo que, provocando o dono da farmácia, esconde dois revólveres atrás do corpo. Zap exibe os óculos de sol com as mãos na cintura. Coyotte parece constrangido pela presença do pai, algo que sem sucesso, tentara evitar. Do outro lado, seu pai segura a espingarda, perplexo com a participação do filho na tentativa de assalto. Eles parecem não ter tido contato por algum tempo, o que é corroborado pela dificuldade do jovem em identificar qual chave abriria o cadeado do lado de fora da farmácia, mesmo que ele ainda carregasse consigo as chaves do local.

A polícia chega $\log$ depois ${ }^{14}$ e o jovem de sobretudo começa o tiroteio

13 Tons de vermelho também predominam no aposento de Amande. Em ambos os casos, as cores propõem um ambiente íntimo, de aconchego e acolhimento.

14 Algo que não voltará a acontecer nas demais ocorrências que integram a narrativa. A partir do momento em que Nikita passa a atuar como agente da inteligência os assassinatos que comete deixam de ser construídos como ocorrências policiais e, assim, a polícia desaparece como que por encanto. No restaurante em que cumpre o rito de passagem que marca o fim de seu treinamento, a polícia é substituída pelos seguranças que trabalham para o homem que ela assassina e nenhuma viatura é vista 
anunciado pela presença da espingarda e dos revólveres na cena. Rapidamente, o dono da farmácia, Coyotte e dois policiais caem baleados. Como que imerso num transe, Zap saca o machado e começa a destruir as prateleiras próximas de si. O personagem de sobretudo, que só então anuncia o próprio nome, Rico, incentiva Zap a prosseguir. Rico mostra-se em pé, altivo por detrás do balcão, atirando a esmo, enquanto outros policiais aparecem do lado de fora da farmácia. Um deles usa óculos de visão noturna, e desde o seu ponto de vista, vê-se a tela preencher-se de vermelho ${ }^{15}$. Ele mira em Rico e acertalhe o peito. Um de seus revólveres cai no chão. Zap continua a destruir o que vê pela frente, dizendo que será bom. Da mesma forma como acertara Rico, o policial atira em Zap, que cai de cima do balcão. A moça, que até então permanecera apoiada no móvel, pega o revólver de Rico. A farmácia aparece numa tomada geral, completamente destruída. Os policiais entram no estabelecimento, checando cada um dos corpos. Um deles encontra a jovem sob o balcão, ainda usando os fones de ouvido. Sem ver perigo em sua figura, ele abaixa sua metralhadora e retira os fones dos ouvidos da moça. Ela pergunta se sobrou alguma coisa, e tal é seu estado de alienação que não é possível dizer se ela quer saber sobre os outros membros do grupo ou sobre a droga que esperava ${ }^{16}$. Frente à resposta do policial, ela coloca a arma contra seu pescoço, sorri ao vê-lo temer por sua vida e atira. Até então imersa numa inexpressividade aterradora, o sorriso que antecede o tiro expressa ao mesmo tempo prazer e poder, convertendo-se em signo de crueldade e sadismo.

A invasão do estabelecimento dos pais de um dos membros do grupo, nestes minutos iniciais do filme, não é aleatória, exacerbando o caráter rebelde desses personagens. Construída com referência à família, a invasão aponta para a negação de valores, estilo de vida, autoridade e propriedade associadas a ela. Apesar de toda a

nos arredores do local quando ela consegue escapar. Seguranças também aparecem durante sua missão em Veneza. No entanto, neste momento, mais que propor um desafio ao cumprimento de suas ordens, como acontece no restaurante, eles aparecem para propor uma maior importância ao seu alvo. Além disso, sua presença colabora no adiamento do momento em que seu alvo é revelado, impregnando a sequência do suspense pela espera da ordem final que possibilitará o cumprimento da missão e a manutenção de seu segredo perante Marco. Finalmente, durante a invasão da embaixada, os guardas substituem a presença da polícia, voltando a apresentarem-se como desafio a ser superado por Nikita e por Victor em sua fuga. Suas ações voltam a ser assunto de polícia apenas depois de sua deserção, algo que se torna visível quando Bob chega a seu apartamento acompanhado por outros três homens em uma viatura.

$15 \mathrm{O}$ vermelho sobre o fundo escuro, tal qual o das letras dos créditos, aparece como referência ao derramamento de sangue e à violência. Em Kill Bill Vol. 1 (Kill Bill: Vol. 1, Quentin Tarantino, 2003), a textura em vermelho, utilizada nas sequências em que a protagonista rememora a participação de seus inimigos no massacre de El Paso, possui esta mesma característica.

16 A ambiguidade da fala do personagem desaparece na sequência pela legendagem. "Il n'y en a plus?" faz referência a algo, não a alguém. 
construção do grupo estar ancorada em signos que remetem à juventude de seus personagens, quando a ruiva e o policial são colocados frente a frente, não é possível vislumbrar uma grande diferença etária entre eles. A sequência deixa ver que a juventude - tal qual proposta pela narrativa - é uma condição que se experimenta pela contraposição à vida adulta e à expectativa do exercício de suas funções. Dessa forma, os personagens que invadem a farmácia apresentam-se como "pessoas biologicamente maduras [que] continuam socialmente imaturas"17. A imaturidade aparece, então, associada ao uso de drogas, à rebeldia e à violência. O que acontecerá a partir daí, transforma Nikita na protagonista de uma experiência muito particular em direção à vida adulta.

A narrativa se organiza, a partir deste momento, em quatro partes de durações desiguais. A primeira delas relata a prisão, julgamento e "execução" de Nikita. A segunda parte constroi a internação de Nikita como possível agente do Estado francês, culminando com sua submissão ao treinamento. Nela são introduzidos na trama os personagens de Bob, o agente responsável pela pacificação da protagonista durante o treinamento, e Amande, sua professora de "boas maneiras". A terceira, mostra Nikita pacificada, seu rito de iniciação como agente e o retorno do personagem ao convívio social. Nesta parte da narrativa, acontece o encontro entre Nikita e Marco, com quem a protagonista passará a ter um relacionamento amoroso. A quarta parte, a mais longa delas, apresenta o desenrolar de seu envolvimento com Marco e as missões de Nikita como agente da inteligência francesa até sua deserção.

A narrativa tem como principais recortes espaciais as cidades de Paris e Veneza. Diferente do que acontece em Sedução e Vingança e Valente em relação à cidade de Nova Iorque, Paris não é tematizada pela narrativa de Nikita. A cidade aparece principalmente através de imagens de diferentes avenidas e edificações, onde uma maior circulação de pessoas pode ser vista durante o dia. Até o início da quarta parte da narrativa, não são usadas imagens de locais que possam facilmente remeter à cidade, como a Torre Eiffel, que aparece apenas quando Nikita começa a planejar a missão da embaixada. São as referências à rua Saint-Denis e ao Hospital Salpêtrière ${ }^{18}$ que colaboram para que o espectador identifique Paris como o espaço primordial da

17 Elias, Norbert. "A individualização no processo social”. In: A sociedade dos indivíduos. Rio de Janeiro; Jorge Zahar Editor, 1994, p. 104.

18 A rua Saint-Denis, situada no centro de Paris, é conhecida como um lugar de prostituição e consumo de drogas. O Hospital La Pitié-Salpêtrière faz parte do sistema de saúde pública francês e é um dos maiores da Europa. 
narrativa de Nikita. Os cenários que constroem os espaços internos se apresentam, dessa maneira, muito mais significativos ao desenvolvimento da narrativa. Entre eles, destacam-se os vários ambientes que compõem a fábrica de agentes, como o quarto de Nikita. Predominantemente branco na sua primeira aparição, as mudanças em seu mobiliário e decoração colaboram para a proposição da passagem do tempo da narrativa e das mudanças no comportamento da protagonista durante seu treinamento. Já a construção da cidade de Veneza utiliza-se principalmente de imagens dos seus canais, vistos durante o passeio de barco de Marco e Nikita e da janela do banheiro do quarto de hotel, através da qual Nikita cumpre sua missão.

O tempo da narrativa de Nikita estrutura-se de forma absolutamente linear, a partir da montagem direta de planos de curta e média duração. Não há remissões de tempo, como flashbacks ou sonhos, que possam justificar ou explicar os acontecimentos do presente da narrativa. Os fade in(s) são utilizados para propor tanto passagens curtas quanto longas de tempo, marcando, fundamentalmente, a transição entre as diferentes partes da narrativa e os renascimentos de Nikita durante a história, que se passa num período de aproximadamente quatro anos.

A linearidade da estrutura narrativa de Nikita ancora-se, em grande medida, na utilização de elementos característicos da construção narrativa clássica hollywoodiana. De acordo com David Bordwell, o filme hollywoodiano clássico apresenta agentes causais mais ou menos elaborados ${ }^{19}$ - os personagens - que se empenham em resolver um problema ou atingir determinados objetivos, entrando, para tanto, em conflito com outros personagens ou com circunstâncias externas. O fim da história é marcado pela inquestionável vitória ou derrota, a resolução do problema e a realização ou nãorealização dos objetivos propostos pela trama. A causalidade apresenta-se, então, como o primeiro princípio unificador da história, motivando, também, os princípios temporais de sua organização. Neste sentido, a trama apresenta a ordem, a frequência e a duração dos acontecimentos da história, de modo a revelar as relações causais mais importantes e fazer com que a duração dramática da narrativa constitua-se como o tempo necessário à realização ou não-realização do objetivo que orienta a história ${ }^{20}$. Para que isso ocorra, a trama clássica é sempre, segundo Bordwell, segmentada em sequências demarcadas

19 Bordwell afirma que, “o personagem mais 'especificado' é, em geral, o do protagonista, que se torna o principal agente causal, alvo de qualquer restrição narrativa e principal objeto de identificação do público". Bordwell, David. "O cinema clássico hollywoodiano: normas e princípios narrativos". In: Ramos, Fernão Pessoa (org.). Teoria contemporânea do cinema, Volume II: Documentário e narratividade ficcional. São Paulo: Editora Senac São Paulo, 2005, p. 279.

20 Cf. Bordwell, David, op. cit., 2005, pp. 278-280. 
através de unidades de tempo, espaço e ação ${ }^{21}$. Contudo,

um segmento clássico não é uma entidade fechada. Ele é espacial e temporalmente fechado, mas casualmente aberto, operando para fazer avançar a progressão causal e abrir novos desenvolvimentos. (...) Cada cena apresenta etapas distintas. Inicialmente temos a exposição que especifica o tempo, o lugar e os personagens relevantes - suas posições espaciais e seus estados mentais atuais (geralmente resultado de cenas anteriores). No meio da cena, os personagens agem no sentido de alcançar seus objetivos: lutam, fazem escolhas, marcam encontros, determinam prazos, planejam eventos futuros. No curso de sua ação, a cena clássica prossegue, ou conclui, os desenvolvimentos de causa e efeito deixados pendentes em cenas anteriores, abrindo ao mesmo tempo, novas linhas causais para desenvolvimento futuro. Uma linha de ação, ao menos, deve ser deixada em suspenso para servir de motivação à próxima cena, que retoma a linha deixada pendente (frequentemente por meio de um "gancho de diálogo").

Em Nikita, múltiplas linhas causais abrem-se e encerram-se até o desfecho da narrativa. Na maior parte das vezes, as relações de causa e efeito desenvolvem-se nas sequências imediatamente posteriores ao seu surgimento, como acontece na apresentação e na primeira parte da narrativa, em que a invasão da farmácia leva à prisão da protagonista, que a leva ao seu julgamento e assim por diante. Outras vezes, as relações de causalidade ficam pendentes por várias sequências. Isto acontece quando Marco pergunta a Nikita porque ela, após seis meses de relacionamento, não lhe apresentara nenhum amigo ou parente. Nikita, então, recebe sua primeira missão como agente. Quando Bob lhe telefona para parabenizá-la pelo sucesso no cumprimento da tarefa, ela o convida para jantar no apartamento do casal, encerrando a linha causal iniciada com o diálogo com Marco e abrindo caminho para a criação de uma nova, que se dará durante o jantar propriamente dito, quando Bob "presenteia" o casal com a viagem à Veneza.

Durante a primeira parte da narrativa os acontecimentos relatados sucedem-se

21 Cf. Bordwell, David, op. cit., 2005, p. 281. 
rapidamente. Interrogatório, pronunciamento de sentença e "execução" são apresentados ao espectador sem que se consiga identificar os lapsos de tempo entre um e outro evento. Dessa maneira, mais que relatar uma sucessão de fatos, tais acontecimentos reforçam o comportamento dissimulado, teimoso, rebelde e violento da jovem.

É somente na delegacia de polícia, durante seu interrogatório, que o espectador tem a confirmação de que a jovem que matara o policial é a Nikita a quem o título do filme se refere. No entanto, seu nome apresenta-se como mote para duas manifestações de violência. Ao ser indagada sobre seu nome completo pelo delegado, a jovem responde com voz esganiçada chamar-se Nikita. O delegado se irrita frente à possibilidade da jovem omitir-lhe a identidade. Num tom ameaçador e irônico, ele a chama de "gracinha" 22. Nikita o repete. O delegado, então, a esbofeteia com força, derrubando-a da cadeira. O investigador que acompanha o interrogatório sugere que devido ao estado de Nikita talvez fosse melhor continuar mais tarde, mas o delegado não lhe dá ouvidos, afirmando que o comportamento "desses imbecis" constitui-se por puro espetáculo ${ }^{23}$. Assim, ainda que de uma maneira completamente diferente da que ocorrera antes, o delegado também duvida que Nikita possa causar-lhe qualquer dano. Contrariada, mas com a voz dócil, ela pede ao delegado um lápis. Satisfeito, como se provasse com isso que estivera certo desde o princípio, ele lhe estende o objeto, que Nikita usa repentinamente para perfurar-lhe a mão contra a mesa, enquanto grita que seu nome é "Gracinha".

$\mathrm{Na}$ sequência da delegacia, ainda que o investigador sugira que Nikita esteja drogada, a expressividade de sua face sugere que a jovem já não se encontra tão entorpecida como estivera na farmácia. Suja e suada, ela cheira uma das axilas ao sentar-se na cadeira, ajeitando-se em frente ao delegado. A aparente docilidade de seu rosto, que inexplicavelmente aparece maquiado, esconde uma fúria que irrompe sem aviso e que não pode mais ser atribuída às drogas, mas sim ao seu próprio temperamento. Assim, o comportamento violento de Nikita ganha autonomia na sequência da delegacia; ela deixa de ser a namoradinha drogada de Rico, para consolidar-se como uma jovem violenta. Nenhuma outra referência ao uso de drogas ou

22 Em francês: cocotte.

23 Apesar do tom pejorativo - que pode ser visto na sequência em questão - há, de acordo com Abramo, uma dimensão espetacular no surgimento de subculturas juvenis das últimas décadas do século vinte. Isto se dá porque há "um imenso investimento na construção de um estilo de aparecimento (modo de vestir, expressão facial, postura de corpo e gesticulação) como sinalizador de sua localização e visão de mundo", mas também porque "tais grupos vêm realizar um aparecimento na cena pública (...); vêm se expor, apresentar suas questões através do espetáculo em praça pública". Abramo, Helena Wendel, Cenas Juvenis, op. cit., 1994, p. xv e p. 46; grifos da autora. 
a sua abstinência será feita na narrativa após esta sequência.

$O$ que se passa na delegacia é particularmente importante para o desenvolvimento da narrativa porque propõe uma diferenciação entre a violência estatal e a violência não-estatal. De acordo com Max Weber, o Estado é

uma comunidade humana que, dentro dos limites de determinado território (...) reivindica o monopólio do uso legítimo da violência física. É, com efeito, próprio da nossa época o não reconhecer, em relação a qualquer outro grupo ou aos indivíduos, o direito de fazer uso da violência, a não ser nos casos em que o Estado o tolere: o Estado se transforma, portanto, na única fonte do "direito" à violência ${ }^{24}$.

Uma das decorrências do monopólio estatal da violência é, segundo Norbert Elias, o grau relativamente elevado de não-violência experimentado em alguns territórios. A pacificação social e a manutenção de um padrão de vida habitual constituem-se, para este autor, em algumas das condições que garantem o exercício da autodisciplina individual e a consequente salvaguarda dos padrões civilizados de comportamento e sentimento no interior de uma sociedade. É característica do processo de resolução pacífica de conflitos intra-estatais, entretanto, uma tensão entre pacificação e violência. Esta tensão se estabelece a partir de conflitos sociais e pessoais, conflitos estes que as instituições pacificadoras - representantes do monopólio legítimo da violência que o Estado reivindica - destinam-se a dominar. Dessa maneira, o Estado, através de seu governo, dispõe de grupos de especialistas, autorizados a fazerem uso da violência em casos de emergência ou de modo a impedir que outros cidadãos o façam, o que poderia levar à contestação da legitimidade de seu monopólio ${ }^{25}$. Assim,

a forma de vida social dentro de um Estado e a pacificação que ela acarreta estão baseadas na violência. A polaridade entre civilização e violência, que poderia, à primeira vista, parecer excessivamente absoluta, revela-se relativa num exame mais minucioso. O que está por detrás disso é a diferença entre pessoas que ameaçam outras com violência ou usam armas e músculos em nome do Estado e [que são] protegidas pela lei, e pessoas que fazem a

24 Weber, Max. "A política como vocação". In: Ciência e política: duas vocações. São Paulo: Cultrix, 1993, p. 56; grifos do autor.

25 Cf. Elias, Norbert. Os alemães: a luta pelo poder e a evolução do habitus nos séculos XIX e XX. Rio de Janeiro: Jorge Zahar Ed., 1997, pp. 161-162. 
mesma coisa sem permissão do Estado e sem a proteção da lei ${ }^{26}$.

O que o filme começa a construir na sequência da delegacia é, exatamente, esta relativização. Nos primeiros minutos do filme, os membros da força policial - entre os quais se destaca o delegado, por sua posição hierárquica ${ }^{27}$ - apresentam-se como aqueles que podem exercer a violência de forma legal e legítima. Nikita e os demais jovens que invadem a farmácia são, em contrapartida, construídos na chave oposta, como portadores de uma violência que aparece como antítese dos padrões civilizados. Uma antítese radical, que identifica os comportamentos e sentimentos não-civilizados ao não-humano, ao animal ${ }^{28}$. Esta identificação começa a ser construída na "carceragem" da delegacia, onde as celas assemelham-se a jaulas. Nikita aparece sentada, acuada junto à parede da última delas. Sem a jaqueta, vê-se que a estampa da parte da frente de seu colete imita a pele de um felino selvagem. A animalização de Nikita é explicitada mais tarde, quando Amande lhe dirá que, se trabalharem arduamente em conjunto, poderão transformá-la num ser humano.

Paulo Menezes argumenta que, no processo em que estabeleceu o homem, branco, europeu, adulto, em plena capacidade física de trabalho, produção e reprodução, como referência na escala civilizatória,

o resto vai se transformar, de outro, de alteridade, com suas individualidades e particularidades diferenciadoras definidoras próprias e não escalonadas, em menos, em falta ou excesso, a partir da determinação de um padrão de normalidade fundada nas necessidades de trabalho da Revolução Industrial. (...) O que não é a referência (homem branco europeu) é reduzido a outras categorias, desvalorizado em sua humanidade por suas aproximações com a natureza, (...) quando visto enquanto disfunção, será banido até mesmo do mundo orgânico, como os "bandidos" e "meliantes", incrustados grosseiramente no mundo inorgânico ao serem taxados de "elementos" pelas forças que resguardam a "ordem" 29 .

26 Elias, Norbert, op. cit., 1997, p. 402, nota 3.

27 Marcada pela presença do investigador e do escrivão, que aparecem como seus subalternos.

28 A instauração do dualismo entre o humano e o animal é abordada por John Berger. O autor argumenta que as diferenças e similaridades que foram percebidas a partir das relações entre homens e animais permitiram que os primeiros se distinguissem dos segundos num processo que, por fim, gerou uma hierarquia que marginalizou os animais em relação ao homem. Cf. Berger, John. "Why look at animals?". In: . About looking. Nova Iorque: Vintage International, 1991, pp. 3-28.

29 Menezes, Paulo. "O nascimento do cinema documental e o processo não civilizador". In: Martins, José de Souza; Eckert, Cornélia; Novaes, Sylvia Caiuby (orgs.). O imaginário e o poético nas ciências 
O que identifica Nikita a um animal é, portanto, tanto seu excesso de violência, quanto sua falta de autocontrole. Se a figura do delegado mobiliza um comportamento que pode ser ou não identificado como abuso do poder policial, a reação de Nikita se apresenta de forma visceral e incontida, reiterando o temperamento violento e animalesco do personagem. Dessa forma, é Nikita quem será julgada e punida pela morte de todos os policiais ${ }^{30}$ que atenderam ao chamado da invasão da farmácia, enquanto o delegado desaparecerá da narrativa. Neste jogo de quem pode e quem não pode ser violento, de quem é punido e quem pune, a sequência antecipa porque, quando Nikita torna-se agente do Estado, sua violência deixa de ser construída como um problema - o que não impede que ela passe por um conflito interno.

A sequência seguinte à da delegacia mostra que ela já não será mais tratada com a mesma ingenuidade mostrada pelo policial e pelo delegado. No tribunal em que é sentenciada à prisão perpétua pelo assassinato dos três agentes do caso Saint-Denis, como o juiz denomina os acontecimentos da primeira noite da história, vê-se Nikita rodeada por inúmeros policiais, que mal são capazes de conter sua reação violenta após o pronunciamento do juiz. A cena exacerba sua força física pelo contraste com o corpo magro e de aparência frágil. O ciclo iniciado na primeira tomada do filme se fecha quando vemos Nikita ser arrastada pelo colarinho pelos corredores do fórum. Diferente da jovem que Zap levava, Nikita debate-se, chuta, agride, grita. A violência parece ser, portanto, a maneira a partir da qual o personagem interage e relaciona-se com o mundo ao seu redor.

Os dias de Nikita como delinquente estão, a partir daí, contados. A sequência seguinte mostra o que aparenta ser o de sua "execução". Ao ver dois homens vestidos de branco abrirem a maleta e preparar o que ela acredita ser uma injeção letal, ela chora e se desespera. No momento em que crê ser o de sua morte, Nikita mostra-se fragilizada pela primeira vez. É também nesta ocasião em que ela, pela única vez, faz menção à família, estranhando a ausência da mãe. Nikita aparece então como uma menina desamparada: contida por uma camisa de força, ela não xinga, se debate ou luta, tudo o que ela faz é clamar por sua mãe. Apesar da dramaticidade da cena, a sequência em questão causa estranhamento, uma vez que nunca antes nenhum membro de sua família

sociais. Bauru: Edusc, 2005 , p. 91; grifos do autor.

30 No diálogo que integra a última sequência do filme, entretanto, a punição de Nikita volta a ser associada à morte de apenas um deles. 
fora mencionado ou visto acompanhar a jovem até ali. Outro estranhamento causado pela sequência é o da própria possibilidade da execução de Nikita pelo Estado, uma vez que, na sequência anterior, ela é vista sendo condenada à prisão perpétua e não à pena capital.

A pena capital foi abolida na França em 1981, após a descoberta de evidências que poderiam ter inocentado Christian Ranucci, executado em 1976. Como na narrativa não se faz referência exata ao momento em que se passa a história, ainda que elementos do figurino dos personagens apontem para algum momento próximo ao do lançamento do filme, e, dada a reação de Nikita na sequência, poder-se-ia argumentar que seria plausível, no interior do enredo, a vigência da pena capital naquele país. Contudo, a sequência propõe uma incompreensão de Nikita em relação à situação em que se encontra, o que sugere que as regras que ela conhecia, a partir dali, foram suspensas. É essa incompreensão que torna possível que o personagem acredite que será executado. Os resultados dos experimentos de Harold Garfinkel sugerem que, em situações de suspensão ou de desestruturação das regras que regem as interações da vida cotidiana, os indivíduos tendem imediatamente a tentar restaurá-las através do que lhes é familiar, o que parece seguro, restabelecendo, assim, a ordem social por meio de seu conhecimento de senso comum ${ }^{31}$. O posicionamento do indivíduo frente à anomia ${ }^{32}$ revela, dessa maneira, seu apego às estruturas sociais conhecidas, trazidas à tona, não raro, na sua faceta mais conservadora. É por isso que, neste momento de desestruturação que é o da sua "execução", Nikita - dominada e sem poder reagir -, pede pela mãe. A família ali aparece como o fix, o é isto para o qual ela retorna em seu anseio de restabelecer a ordem das coisas ${ }^{33}$.

A impressão de Nikita de que será executada é corroborada, também, pela feição impassível dos enfermeiros e pelo exagero de se proteger um simples sonífero com uma fechadura eletrônica, dentro de uma maleta que em nada se parece a uma maleta de profissionais de saúde. A maleta, entretanto, aparece como indício do tipo de mundo em que Nikita será inserida, o da espionagem. Neste sentido, não por acaso o segredo que a

31 Cf. Garfinkel, Harold. "Studies of the routine grounds of everyday activities". In: Studies in Ethnomethodology. Englewood Cliffs, NJ: Prentice-Hall, 1967, pp. 35-75.

32 De acordo com Émile Durkheim, a anomia constitui-se na ausência de regras morais capazes de regular as relações sociais do trabalho no mundo econômico moderno. A partir dele, em que o estado de anomia é constante e normal, a ausência de regras que disciplinam as relações sociais estende-se às demais esferas da vida social. Cf. Durkheim, Émile. A Divisão Social do Trabalho. São Paulo: Martins Fontes, 1999, pp. VI-VII; e, Durkheim, Émile. O Suicídio. São Paulo: Martins Fontes, 2000, pp. 323325.

33 Cf. Garfinkel, Harold, "Studies of the routine grounds of everyday activities", op. cit., 1967, p. 35. 
maleta guarda é protegido eletronicamente. Nos mundos da espionagem construídos filmicamente, há muito tempo o desenvolvimento tecnológico aparece como um dos elementos que propõem a superioridade de um Estado qualquer, algo que os filmes que relatam as missões de James Bond nada mais fizeram que elevar a dimensões espetaculares. É nesta chave, portanto, que aparecem a maleta, as escutas, os comunicadores, os computadores e os óculos-câmera utilizados durante a narrativa.

Assim, não é o encarceramento, mas sim a "execução" que simboliza a morte de Nikita para o mundo exterior. Mesmo na delegacia a ênfase construída na narrativa não é a do encarceramento. Após o pronunciamento da sentença não a vemos numa cela uma única vez. A única sequência de seu tempo na cadeia é a da "execução", que se passa num ambiente praticamente sem utensílios, protegido por um guarda do lado de fora e por outro do lado de dentro. O salão no qual ocorre sua "execução" configura-se, então, como um espaço de transição para o mundo paralelo criado no interior da fábrica de agentes, onde se desenvolverá a segunda parte da narrativa.

A passagem da primeira para a segunda parte da narrativa é construída a partir de um fade in, que mostra os pontos de vista de Nikita ao perder a consciência - na sala em que lhe aplicam o sonífero na prisão - e ao recobrá-la - no quarto de número sete da fábrica de agentes. É este espaço que será sua cela durante os três anos em que permanece internada na fábrica. É também ali que Nikita tem seu primeiro contato com $\mathrm{Bob}^{34}$, o agente encarregado de sua pacificação.

A brancura do ambiente e do figurino de Nikita contrastam com as roupas negras do homem, que entra com uma pasta na mão, e com suas antigas roupas, coturnos e um pequeno bicho de pelúcia, que repousam sobre a cadeira em frente da cama. Bob move a mesa e a cadeira de modo a que possa sentar-se a sua frente e pergunta qual o seu nome. Ela responde, o que lhe arranca um meio sorriso. Ele continua a conversa, elogiando-o e perguntando sua origem, que ela diz ser de uma canção ${ }^{35}$. Confusa e

$34 \mathrm{O}$ nome do personagem é revelado apenas quando Nikita regressa do restaurante onde cumpre o rito de iniciação como agente.

35 Possivelmente uma referência a Nikita (Elton John e Bernie Taupin). Lançada no álbum Ice on Fire (Geffen Records, 1985), a canção interpretada por Elton John foi um grande sucesso em muitos países. A letra conta a história de um amor impossível por um soldado, devido à separação do "ocidente" e do "oriente" simbolizada pelo Muro de Berlim durante os anos da Guerra Fria. Apesar de Nikita ser um nome masculino de origem russa, o videoclipe da canção apresentou uma soldado como par romântico do cantor, o que poderia justificar o uso do nome para um personagem feminino. Além disso, as aparências da Nikita do filme e da do videoclipe assemelham-se quando o personagem do filme torna-se um agente na terceira parte da narrativa, apesar de as atrizes terem tipos físicos bastante diferentes. Neste momento, contudo, a referência à canção causa um certo estranhamento, uma vez que sua melodia suave e romântica em nada remete à construção do personagem até este momento do 
chorando, ela lhe pergunta se ali é ou não o céu. Bob desconcerta-se, sua feição torna-se grave e ele nega, dizendo em seguida que pode vir a ser. Enquanto narra-lhe os detalhes de sua "morte" e "sepultamento", ele mostra uma série de fotos de seu "enterro", que se apresentam como prova da veracidade daqueles acontecimentos. Segundo André Bazin, à imagem fotográfica é atribuída, desde sua gênese, uma objetividade essencial, que lhe confere um poder de credibilidade que não se iguala ao de nenhuma outra forma pictórica. Ao revelar uma cena capturada pela objetiva da câmera, a fotografia torna-se prova de sua existência num momento passado, cena congelada, embalsamada em seu único e breve instante. Por isso, a imagem fotográfica não se distingue do seu modelo. Ao contrário, aprisiona-o e torna-se $o$ modelo ${ }^{36}$.

Sejam quais forem as objeções do nosso espírito crítico, somos obrigados a crer na existência do objeto representado, literalmente re-presentado, quer dizer, tornado presente no tempo e no espaço. A fotografia se beneficia de uma transferência de realidade da coisa para sua reprodução ${ }^{37}$.

Assim, se as fotografias que lhe são mostradas não são prova de que morrera, são de que pensam que ela foi sepultada na fileira 8, lote 30, do cemitério de MaisonAlfort. Se antes parecia que ninguém se importava com seu destino, a encenação de sua morte põe fim a qualquer relação que Nikita poderia ter tido no mundo exterior à fábrica. Ela não contesta, mas sem voltar a fazer qualquer menção à mãe ou à família ${ }^{38}$, Nikita aponta para a imagem do amigo Titi, um jovem de cabelos espetados e parcialmente descoloridos, "apresentando-o" a Bob com um tom carinhoso. Com isso ela mostra que ainda não compreendera o significado daquilo que lhe estava sendo relatado, de que seus vínculos com o passado estavam mortos e enterrados.

Numa reação diferente da que tivera quando Nikita lhe revelara a origem de seu nome, Bob a ignora e desconversa. Ele revela que é funcionário do governo, que resolvera dar-lhe uma segunda chance, agora servindo ao seu país, devendo para tanto aprender a "ler, andar, falar, rir e até, lutar". Dada a possibilidade da "escolha" entre o serviço ou a morte - aludida pelas coordenadas de "sua" sepultura -, Nikita pede-lhe

36 Bazin, André. "Ontologia da imagem fotográfica". In: O Cinema - Ensaios. São Paulo: Brasiliense, 1991b, p. 21-24.

37 Bazin, André, op. cit., 1991b, p. 22.

38 Cuja presença, durante o "sepultamento", pode ser inferida quando a câmera mostra a primeira foto da sequência que Bob entrega a Nikita. 
um tempo para descansar antes de responder. Esta sequência marca o primeiro renascimento do personagem na narrativa. Aqui, morte e renascimento confundem-se de forma mais evidente. A brancura asséptica do ambiente - que remete tanto a um espaço hospitalar quanto de laboratório - e o brinquedo de pelúcia marcam o momento em que a vida de Nikita é concebida como uma página em branco, pronta para ser (re)escrita. Da mesma forma como este renascimento alude à primeira infância, a cada vez que Nikita tem que reinventar-se, ao mesmo tempo em que ela parece recomeçar do zero, alguns de seus comportamentos podem ser associados a diferentes etapas da vida humana. As diferentes maneiras como o quarto aparece decorado em cada um desses momentos simboliza e enfatiza cada uma destas etapas.

Quando Bob volta ao quarto, Nikita, vestida com suas roupas antigas, volta a agir de forma violenta. Ela o espanca e rende, tentando usá-lo como escudo para fugir. Uma vez frustrada sua tentativa de fuga, vendo-se novamente sem saída, ela aponta a arma que tomara dele em direção à própria boca e aperta o gatilho. Não há bala naquele orifício do tambor e Nikita é novamente rendida por ele que, irritado, atira em sua perna para mostrar-lhe quem está no comando. Bob mostra um controle da situação que até então não se havia presenciado, dominando-a sem a ajuda dos outros agentes que são vistos no ambiente. Uma vez que ele deixara o primeiro orifício do tambor da arma vazio, não se pode dizer que a tentativa de fuga de Nikita o pegara completamente de surpresa, ainda que ela consiga rendê-lo. Bob mostra cautela ao regressar ao quarto de Nikita após sua tentativa de fuga, mas a incentiva quando ela se mostra insegura quanto ao seu destino, depois de aceitar a "oferta".

Nas sequências que seguem e que relatam um período de três meses, vemos Nikita oscilar entre a cooperação e a rebeldia. "Ler, andar, falar, rir e até, lutar" convertem-se, na tela, em aulas de informática, tiro, artes marciais e "boas maneiras". Nikita interage pouco com os outros ocupantes da fábrica que abriga seu aposento, as diferentes salas de aula e o amplo salão, onde se veem muitas mesas com computadores. É numa delas que a sua primeira aula é apresentada.

A câmera passeia pelo ambiente, da direita para a esquerda, até mostrar o personagem sentado em frente a um monitor de computador. Seu professor, em pé ao lado de Nikita, diz que começarão com um programa fácil, para então familiarizá-la com o teclado e o mouse $e^{39}$. Enquanto Nikita move o acessório freneticamente sobre a

39 Não é de se estranhar que Nikita não conheça o mouse. As primeiras interfaces gráficas que permitiram a utilização do dispositivo, apresentando setas que se moviam sobre janelas e ícones, 
mesa, o professor pede-lhe calma e dá outras instruções. A câmera aproxima-se e a interface de um programa de desenho aparece em seguida, deixando ver os rabiscos feitos pela jovem tingirem-se de azul sob o plano de fundo vermelho. O professor, abaixado bem próximo à Nikita, sorri, satisfeito. Seu sorriso se desfaz quando ela, como uma criança, pede para repetir o feito ${ }^{40}$.

Um corte leva à segunda aula de Nikita, que acontece num amplo estande de tiro. A câmera desloca-se pelo ambiente, também da direita para a esquerda, mostrando um atirador, acompanhado por um instrutor, disparar cautelosamente em direção a um alvo ao fundo. A câmera termina seu passeio em frente a uma mesa onde diferentes armas estão dispostas. Não bolso da jaqueta de Nikita, vê-se seu coelho de pelúcia aparecer pela segunda vez, reforçando tanto a infantilização de Nikita neste momento da narrativa quanto a aparência inofensiva do personagem. Outro instrutor de tiro apresenta as armas utilizadas pelos agentes à jovem, que aparece mascando chiclete. Ele fala sobre a arma mais simples, a Beretta 93R, uma pistola automática de calibre $9 \mathrm{~mm}$ e que pode disparar até vinte tiros. Sem saber que ela sabe atirar, ele lhe entrega a arma, pedindo que ela aponte o cano em direção ao alvo. $\mathrm{O}$ instrutor prossegue com suas instruções, sugerindo que ela familiarize-se com a pistola antes de aprender a posição correta para atirar no alvo, localizado a dez metros de distância. Nikita posiciona-se com rapidez e dispara, sem qualquer dificuldade, várias vezes. A câmera focaliza-a de frente, abandonando-a apenas para mostrar o outro atirador sair de sua posição para olhar em sua direção, surpreendido. Atrás dela, vê-se o instrutor de tiro, boquiaberto, aproximar-se do alvo que se movimenta em sua direção, estraçalhado. Quando ele pergunta se ela já havia usado uma pistola como aquela antes, ela lhe responde que nunca havia atirado em um alvo de papel. A sequência mostra mais uma vez que a figura de Nikita engana. Ninguém parece ser capaz de perceber os perigos que se escondem por trás da figura de aparência frágil do personagem.

foram desenvolvidas na primeira metade da década de 1980, quando os microcomputadores eram ainda pouco populares. O Apple Lisa, primeiro microcomputador a ter um interface gráfica e utilizar o mouse, custava quase dez mil dólares em 1983, quando foi lançado. O Windows 1.0, que incluiu pela primeira vez o programa Paintbrush, similar ao que é utilizado na sequência, surgiu no final de 1985. O lançamento do Windows 3.0, produto que consolidou a Microsoft no mercado, começou a ser comercializado apenas em 1990, ou seja, no mesmo ano do lançamento do filme. Assim, o que a sequência propõe é que, na fábrica de agentes, Nikita tem acesso a mais alta tecnologia disponível naquele momento.

40 O professor, sem dúvida, é tomado por uma sensação de estranhamento. De acordo com Sigmund Freud, a compulsão à repetição, "procedente dos impulsos instintuais e provavelmente inerente à própria natureza dos instintos (...) [é] muito claramente expressa nos impulsos das crianças pequenas". Segundo este autor, qualquer coisa que lembre a compulsão à repetição é percebida como estranha. Freud, Sigmund, “O 'estranho"”, op. cit., 1969, pp. 297-298. 
Tal proposição será reiterada durante sua primeira aula de artes marciais. Sem poder participar das atividades coletivas devido ao ferimento à bala que tem na perna, ela aparece sentada em frente ao tatame, olhando os outros usuários da academia. No fim da aula, o professor a chama, propondo um exercício para testar seus reflexos. Nikita gruda o chiclete na tampa da garrafa de água que carrega e levanta-se, encarando o professor. Frente a frente, os dois posicionam-se: ele movimenta-se em sua direção sem que Nikita desvie-se dele, para então erguer os braços empunhados. Esta é uma das imagens que mais associam a violência à sexualidade de Nikita durante toda a narrativa. Seus braços e punhos aparecem como um prolongamento de seus seios e mamilos que, enrijecidos, insinuam-se sob a camiseta ${ }^{41}$. O professor lhe pede, então, para tentar acertar-lhe o rosto, e ela prontamente o esbofeteia, fazendo com que ele se desequilibre para trás, surpreendendo-o pelo inusitado. Ao propor um exercício "simples" cujo sucesso causar-lhe-ia grande humilhação, fica claro que o professor não contava com a possibilidade de a jovem ser capaz de realizá-lo.

Bob, que os observa a distância, balança a cabeça negativamente, mas sorri, divertindo-se com a ingenuidade do professor e a audácia de Nikita, possivelmente demonstrando começar a nutrir por ela alguma simpatia. Mais do que propor uma aproximação entre os dois personagens, a presença de Bob na cena sugere que ele se dá conta que a principal arma de Nikita constitui-se na impressão de que ela não oferece perigo algum. Por isso, quando seu superior lhe dá um ultimato, insatisfeito com o comportamento e os "progressos" de Nikita, Bob a defende, dizendo que ela tem potencial. Esta sua "qualidade" é, portanto, o que justifica a sua escolha como possível agente. O corpo frágil, de aspecto inofensivo, constitui-se, assim, no disfarce perfeito para qualquer agente da inteligência autorizado a matar, como se tornará Nikita na quarta parte da narrativa. No fim da sequência, a câmera volta-se novamente à jovem e ao professor, que se cumprimentam pouco antes dele chamar pelos alunos da próxima turma. Quando Nikita deixa a academia, já não se vê Bob que, satisfeito, deixara o local.

A aula mais interessante é, sem dúvida, a de "boas maneiras". Ao deixar a academia, Nikita passa por seu quarto e se depara com algumas caixas e um móvel sobre o chão no centro do aposento. Visto de frente desde a porta, o quarto já não é dominado pela brancura de antes. Do lado esquerdo, o pôster vermelho colado na

41 Uma variação desta proposição aparece reiterada e exacerbadamente nos filmes da série Tomb Raider em relação ao personagem de Lara Croft, o que será discutido no Capítulo IV deste volume. 
parede, a toalha amarela sobre a mesa e o colchonete azul formam um triângulo que chama atenção para as mudanças no interior do aposento e compõem um cenário de atividade. Do lado direito, o pôster escuro, o abajur marrom claro cujo tom é parecido com o de sua manta, compõem o espaço do repouso, menos atrativo ao olhar. A rápida passagem de Nikita pelo quarto, ao mesmo tempo em que introduz as mudanças no cenário deste espaço durante o filme, apresenta os signos de sua cooperação: o material de estudo sobre a mesa, a cama arrumada, o colchonete de ginástica, os objetos de uso pessoal sobre os móveis. Mas, ao invés de ser construído como um espaço reservado à privacidade, os objetos (que aparecem subitamente no quarto), a sirene (que a avisa quando precisa encaminhar-se para a próxima atividade) e a porta (que deixa aberta atrás de si), propõem que o quarto que ocupa nada mais é que uma extensão da fábrica.

Ao chegar ao aposento de Amande ${ }^{42}$, sua professora de "boas maneiras", a contraposição é evidente ${ }^{43}$. Situado no andar superior, cujo acesso se dá por uma escada em formato de caracol localizada ao fundo do amplo salão, numa parte dele que é mal iluminada, a decoração do ambiente, em que predominam cores quentes, cria uma atmosfera de intimidade ${ }^{44}$. Amande, entretida com seus afazeres, não percebe sua presença. Nikita assovia para chamar-lhe a atenção. A professora olha primeiro em direção à janela, como se o barulho que a perturbara viesse de fora, para depois virar-se para a jovem, checando o relógio em seguida. Com a feição severa, a senhora avalia sua figura de cima a baixo e pede para que se sente em frente à penteadeira. As fotos que têm de Nikita coladas na parede sobre o móvel mostram que ela será responsável pela transformação da sua aparência, a começar pelos cabelos. Não por acaso, portanto, a protagonista aparece numa tomada de corpo inteiro pouco antes da senhora dar-se conta de sua presença. Os cabelos desgrenhados, a jaqueta que usava na introdução da narrativa, a calça cortada na altura dos joelhos e os coturnos constituem-se em vínculos do personagem com seu passado e constroem uma aparência desleixada. As primeiras ações da senhora constituem-se em fazê-la livrar-se do chiclete, colocar-lhe a peruca na cabeça, tirar-lhe a jaqueta e ajeitar o colarinho de sua blusa, fazendo com que Nikita ganhe uma aparência "mais feminina". A sequência, grande parte construída a partir de uma paralelismo de planos que ora mostram a imagem da garota pelo espelho da

42 Assim como acontece com Bob, o nome de Amande será revelado apenas na noite em que Nikita cumpre o rito de iniciação como agente.

43 A música, que acompanhara todas as outras aulas vistas até ali, cessa quando Nikita chega ao topo da escada, o que propõe, também, uma outra diferenciação em relação ao que se passará no aposento.

44 A proposição de intimidade é reforçada também pela ausência de outros alunos, ainda que nas demais aulas os professores apareçam interagindo primordialmente com a protagonista. 
penteadeira, ora mostram a professora de frente e Nikita de perfil, tem um diálogo revelador de uma proposição de feminilidade, que se baseia na aparência e no comportamento gracioso:

\begin{abstract}
Amande: - Minha querida garota, você não está com grande aspecto agora. Chiclete. Mas se trabalharmos duro juntas e a sorte nos sorrir, nos tornaremos capazes de transformá-la num ser humano, um passo intermediário, mas necessário antes de se tornar o complemento perfeito de um homem: uma mulher. Gosta? Você consegue me dar uma definição de graça?

Nikita: - Não sou esperta.

Amande: - Então sorria, será um bom começo. Sorria quando não souber alguma coisa. Você não ficará mais esperta, mas é agradável para os outros. Deixe-se dominar pela fragilidade que tornará seu rosto belo. Um sorriso é doçura à flor da pele, suavidade, quase um estado da alma. Vamos fixar a peruca?
\end{abstract}

Amande apresenta-se como o personagem que realiza esta proposição de feminilidade plenamente. Sua aparência é ao mesmo tempo luminosa e sóbria: os cabelos louros perfeitamente penteados num coque frouxo emolduram sua face, cuja maquiagem leve combina com o figurino, que mescla tons de amarelo, laranja e marrom $^{45}$. A mesma combinação de cores aparece nos seus acessórios: a corrente e os anéis de ouro, a pedra alaranjada do broche e os grandes brincos de um bronze envelhecido. A senhora tem uma postura altiva, mas delicada. Move-se pelo aposento devagar, fala baixo, toca o rosto de Nikita com cuidado. Enquanto Nikita, de frente ao espelho, tenta em vão sorrir - mostrando uma feição que mais remete à tristeza e ao choro -, ela abre um sorriso carinhoso. Amande mostra-se, dessa maneira, como a personificação da graça que pedira para Nikita definir ${ }^{46}$.

45 Diferente dos outros professores de Nikita que usam roupas civis, Amande não usa crachá.

46 A atribuição do papel de Amande a Jeanne Moreau é significativa. A atriz era considerada pouco fotogênica, porém, tornou-se uma das musas da nouvelle vague ao revelar-se dona de uma sensualidade discreta, mas marcante. Cf. Stam, Robert. "The prototype for Catherine - Helen Grund Hessel". In: __. François Truffaut and Friends: Modernism, Sexuality, and Film Adaptation. Piscataway, NJ: Rutgers University Press, 2006, p. 60. Nesta mesma direção, o texto que compõe a biografia da atriz em seu website afirma que, longe de ser bonita, ela tem a capacidade de persuadir o espectador do contrário. Cf. Thomson, David. Biography. Disponível via URL: http://www. jeannemoreau.com/bio.htm; acessado em 12/06/2010. Deste modo, nada mais apropriado que ter no papel de Amande uma atriz cuja imagem pública está associada à possibilidade de transformação da figura feminina. 

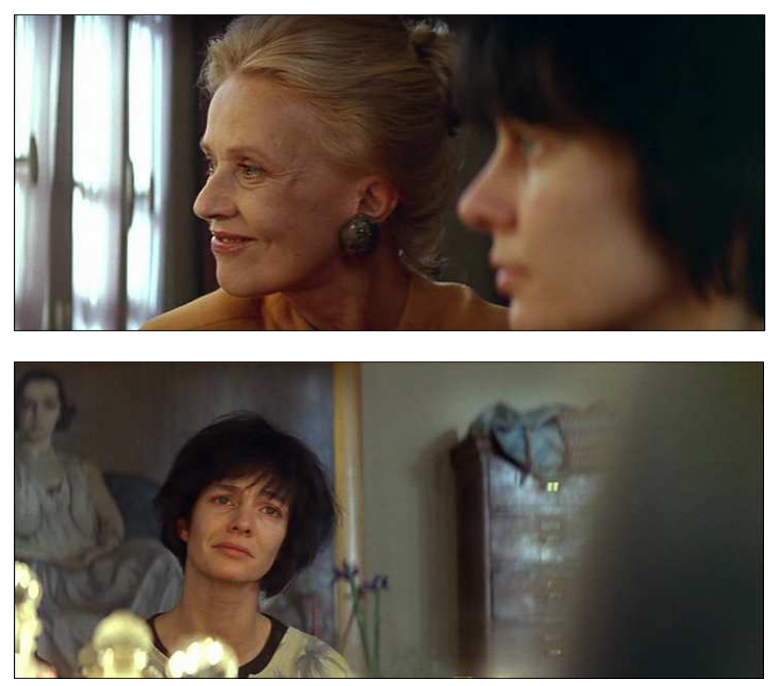

A peruca será, neste momento, marca do que se pretende que Nikita se converta. Após a protagonista ter o pedido de sair para comemorar seu aniversário de vinte anos negado por Bob, ela é vista de volta em seu quarto, fitando-se no espelho e tirando o acessório. A parede do fundo, refletida no espelho, já não tem os cartazes, uma indicação de que o personagem voltará a agir na mesma chave que antes.

Nikita volta então a rebelar-se, presenteando o professor de informática com o rato que coabita seu quarto. Ela o menciona na mesma ocasião em que pede a Bob para sair em seu aniversário, após ele lhe perguntar se ela havia feito amigos. Na sequência, o animal - com quem ela diz que se dá bem - parece remeter o ambiente da fábrica a uma prisão. No entanto, o rato que aparece como presente mais se assemelha a um animal de laboratório, usualmente descartado após os experimentos. O rato - pequeno, alvo, limpo - identifica, assim, o ambiente da fábrica a um laboratório, Nikita a uma cobaia e seu processo de pacificação a um experimento, que resultará, por fim, no descarte do animal, na sua morte ${ }^{47}$. Algo que Nikita se dá conta quando Victor, o "limpador", aparece durante sua última missão, um acontecimento que será determinante para sua deserção. Naquele momento, contudo, Nikita usa o bicho para

47 Pode-se dizer que há um aspecto experimental nas instituições totais. Para Erving Goffman, todas as instituições sociais tendem, em alguma medida, ao "fechamento". De acordo com os termos deste autor, a fábrica de agentes pode ser considerada como uma instituição total, uma vez que o caráter total de uma instituição "é simbolizado pela barreira à relação social com o mundo externo e por proibições à saída que muitas vezes estão incluídas no esquema físico. (...) A instituição total é um híbrido, parcialmente comunidade residencial, parcialmente organização formal. (...) Em nossa sociedade, são as estufas para mudar pessoas; cada uma é um experimento natural sobre o que se pode fazer do eu". Goffman, Erving. Manicômios, prisões e conventos. São Paulo: Perspectiva, 2003, p. 16 e p. 22. 
debochar do professor que lhe ensinara a usar o mouse, como mais uma demonstração do senso de humor que Bob elogiara.

A rebeldia de Nikita aparece novamente associada à animalidade na sequência em que, após ser dominada pelo professor de artes marciais num exercício, ela mordelhe a orelha, puxa seu cabelo e chuta-lhe o queixo. O professor, surpreendido uma segunda vez pela jovem que não compartilha com os demais as regras do "combate" que se dá durante o treino, cai desmaiado no tatame, sendo amparado por dois outros alunos. Novamente visto observando Nikita durante a aula, Bob desvia o olhar quando a jovem agride o professor, mas se diverte ao vê-la imitar uma bailarina.

O fim da fase rebelde de Nikita é construído na sequência em que o agente a visita em seu quarto após receber o ultimato do diretor do programa. A jovem assiste à sequência final de Caroline Chérie (Richard Pottier, 1951) pela TV. Nela, Caroline encontra-se nos braços de um desconhecido, dizendo que pode estar em um sonho. A tela do aparelho teve as bordas pintadas de vermelho e o centro pintado com algumas bolas amarelas. A brancura das paredes do quarto foi substituída por diversas pichações com conteúdo sexual, alguns desenhos de traços infantis e pôsteres. O agente entra, substituindo o pôster que ela tem do lado da cama por outro, uma reprodução de $A$ primeira bailarina (Edgar Degas, 1878). Ele faz um comentário sobre seu progresso em artes e dança e sobre como nas outras disciplinas não alcançou progresso algum. Então, apaga a luz do abajur que ilumina o aposento e sai, pedindo que ela o espere. Quando volta, traz consigo um bolo de aniversário coberto por velas cor-de-rosa acesas. Ele a cumprimenta, ordena que ela as apague e lhe oferece um pedaço, após cortar o bolo com um canivete. Enquanto ela come, ele lhe dá a notícia que não poderá fazer mais nada por ela depois de duas semanas. Ela imediatamente para de mastigar. Ao retirar-se, Bob leva consigo os coturnos e a jaqueta de Nikita, num sinal de que sua rebeldia já não pode mais existir ${ }^{48}$. Seu sonho tivera um desfecho muito diferente daquele em que Caroline pensara estar ao acordar nos braços do desconhecido. No seu caso, não há um

48 No sentido proposto por Goffman de que "um conjunto de bens individuais tem uma relação muito grande com o eu. A pessoa geralmente espera ter certo controle da maneira de apresentar-se diante dos outros". Goffman, Erving, op. cit., 2003, p. 28. Ao ser "despida" de sua aparência habitual, o eu de Nikita é desfigurado. Segundo Goffman, a perda do equipamento de identidade - suas roupas e demais objetos pessoais - geralmente acontece quando o indivíduo é admitido em algumas instituições totais. É interessante que, na experiência que acontece na fábrica de agentes, há primeiro um movimento de reconfiguração do eu de Nikita - quando Bob lhe leva as roupas e sapatos antigos e uma tentativa de transformar esse eu reconfigurado - expresso mais evidentemente através da intervenção de Amande - para só então acontecer a desfiguração, que aparece, então, como perda de um privilégio. Cf. Goffman, Erving, op. cit., 2003, p. 50. 
salvador que virá socorrê-la no último momento, algo que pode ser compreendido como uma clara indicação de que Nikita faz parte de um outro tipo de personagem feminino. Ela abandona o pedaço de bolo que Bob lhe oferecera e a palavra Fin preenche a tela da TV.

O aniversário de Nikita marca, dessa maneira, um novo renascimento do personagem. Sem saída, nada mais lhe resta que submeter-se ao Estado e ao treinamento, render-se à disciplina da fábrica que produzirá seu corpo dócil. De acordo com Michel Foucault,

é dócil um corpo que pode ser submetido, que pode ser utilizado, que pode ser transformado e aperfeiçoado. (...) $\mathrm{O}$ momento histórico das disciplinas é o momento em que nasce uma arte do corpo humano, que visa não unicamente o aumento de suas habilidades, nem tampouco aprofundar sua sujeição, mas a formação de uma relação que no mesmo mecanismo o torna tanto mais obediente quanto mais é útil, e inversamente. Forma-se então uma política das coerções que são um trabalho sobre o corpo, uma manipulação calculada de seus elementos, de seus gestos, de seus comportamentos. O corpo humano entra numa maquinaria de poder que o esquadrinha, o desarticula e o recompõe. (...) A disciplina fabrica assim corpos submissos e exercitados, corpos "dóceis". A disciplina aumenta as forças do corpo (em termos econômicos de utilidade) e diminui essas mesmas forças (em termos de obediência) ${ }^{49}$.

Se o evento que motivou o enredo apresentou-se num primeiro momento como uma agressão à família, o caráter rebelde e violento de Nikita que é construído durante esta parte da narrativa desloca o conflito geracional para um âmbito cultural mais abrangente, que usa, por um lado, a música como alusão a padrões e valores em disputa e, por outro, o Estado como instituição civilizadora. A relação entre Nikita e a música aparece desde o início da narrativa. Primeiro, na presença dos fones de ouvido durante a invasão da farmácia, depois na origem de seu nome e, por último, quando se rebela contra seus professores. A marcha que ela canta após presentear o professor de informática com o rato e a trilha sonora que acompanha a sequência em que dança

49 Foucault, Michel. Vigiar e punir: nascimento da prisão. Petrópolis: Vozes, 1987, p.. 118 e p. 119. 
ballet após agredir o professor de artes marciais aludem aos valores tradicionais que, supostamente, a juventude pôs em xeque na segunda metade do século vinte, muitas vezes através de diferentes estilos musicais. Em contrapartida, ao presentear-lhe como a reprodução de Degas, Bob amplia este escopo $^{50}$, colocando um ponto final na associação "juvenil” do personagem com a música. O Estado, então, aparece como a instituição que, através da força, impõe a adequação aos padrões sociais vigentes, quando não consegue fazê-lo pelas instituições tradicionais. Tornar-se adequado e funcional converte-se, assim, em questão de vida ou morte para Nikita. Se o filme mostra a experiência de Nikita em direção à maturidade e à individualização, ela é construída a partir de uma intervenção radical, que visa a cooptação de sua natureza violenta para fins de Estado. Foucault aponta que o indivíduo interessa ao Estado somente na medida em que ele pode fazer algo pelo seu poderio e manutenção:

do ponto de vista do Estado, o indivíduo apenas existe quando ele promove diretamente uma mudança, mesmo que mínima, no poderio do Estado, seja esta positiva ou negativa. O Estado tem que se ocupar do indivíduo apenas quando ele pode introduzir tal mudança. E tanto o Estado lhe pede para viver, trabalhar, produzir e consumir, como lhe exige morrer ${ }^{51}$.

No caso de Nikita, o Estado também exige que ela "torne-se mulher". A sequência que propõe a aceitação do treinamento pelo personagem mostra a visita de Nikita a Amande. A garota se mostra aberta a uma interação com a senhora, que mais uma vez propõe um sentido de feminilidade a ser incorporado por Nikita, enquanto ela passa repetidamente um batom rosa sobre os lábios em frente ao espelho. Diz a senhora:

50 É interessante, contudo, que tal ampliação tenha se dado através da obra de um pintor impressionista. Se a fotografia já havia liberado a pintura de sua obsessão pela semelhança, como defende Bazin, a ilusão do movimento permaneceu uma necessidade psicológica da pintura desde o surgimento da perspectiva. Cf. Bazin, André, "Ontologia da imagem fotográfica”, op. cit., 1991b, pp. 19-26. De acordo com Menezes, o impressionismo, sem conseguir superar os esquemas de representação da Renascença, mas ao mesmo tempo liberto das amarras da imitação, acirrou "as contradições que fariam explodir a representação espacial a partir de um único ponto de vista". Menezes, Paulo. $A$ Trama das Imagens: Manifestos e Pinturas no Começo do Século XX. São Paulo: Edusp, 1997, p. 90. Dessa forma, se Degas e outros pintores impressionistas conseguem realizar completamente a ilusão do movimento a partir da fluidez das formas, o impressionismo parece ter tanto um elemento de ruptura quanto significar um momento de máxima realização do esquema clássico de representação. É, provavelmente, neste sentido, que a obra de Degas figura na narrativa como afirmação de uma cultura tradicional.

51 Foucault, Michel. “A Tecnologia Política dos Indivíduos”. In __. Ética, Sexualidade e Política. Rio de Janeiro: Forense Universitária, 2006 (Ditos e Escritos; V), p. 308. 
“Deixe-se guiar pelo prazer, prazer feminino. E não se esqueça, há duas coisas que não têm limite: a feminilidade e as formas de nos aproveitarmos dela".

A feminilidade, tal qual proposta por Amande neste diálogo, apresenta-se como uma vantagem. Apesar de Nikita não precisar seduzir ninguém durante as missões que são mostradas na quarta parte do filme, há, aqui, uma referência ao uso da feminilidade como uma arma. A narrativa, contudo, não consegue escapar da associação entre espionagem e sedução que pode ser vista frequentemente em filmes que apresentam espiãs: uma agente não pode, neste sentido, deixar de ser feminina. A feminilidade de Nikita parece, apesar disso, ser exercida muito mais na vida privada, através de sua relação com Marco.

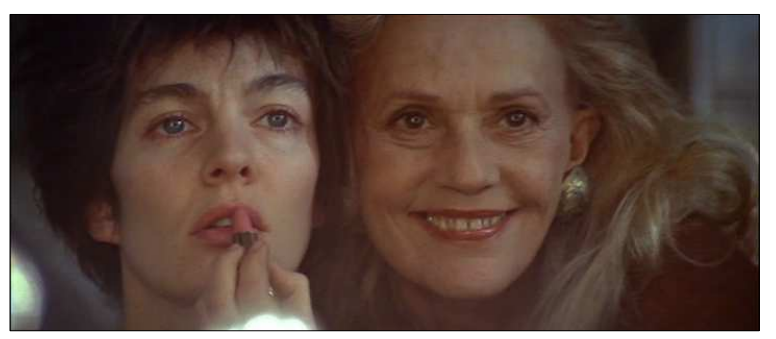

Ao aceitar o treinamento, Nikita e Amande aparecem lado a lado pelo espelho, deixando evidente que, a partir de então, trabalharão juntas, como antes havia lhe proposto a professora. Um fade in, que novamente marca a transição para a parte seguinte da narrativa, mostra a metamorfose de Nikita.

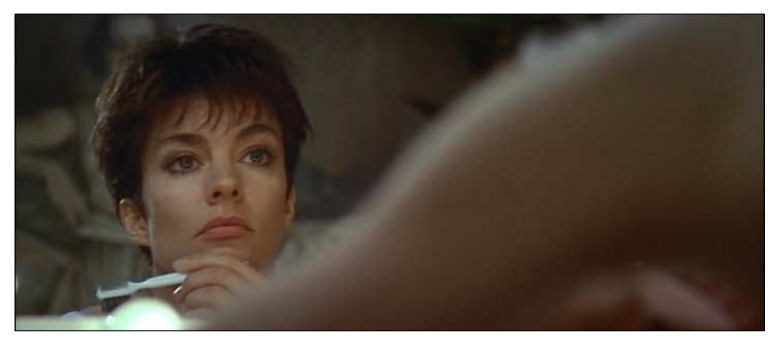

A mesma tonalidade do batom é a única coisa que a imagem de Nikita de três anos depois tem em comum com a da garota que fora visitar Amande. Os cabelos mais curtos e arrumados, as sobrancelhas modeladas e a maquiagem que destaca os olhos e afina seu rosto são os aspectos mais visíveis de sua transformação. Nikita se mostra absolutamente segura de si em frente ao espelho arrumando-se calma e meticulosamente. Amande, que é chamada pelo nome pela primeira vez nesta 
sequência, apressa-a para o que seria o jantar de comemoração do seu aniversário de vintes e três anos. Nesta noite, entretanto, uma missão lhe é designada, um rito de passagem que marca o fim do treinamento e o seu retorno ao convívio social.

Bob encontra Nikita no amplo salão da fábrica, perto de onde a mesa de jantar fora cuidadosamente montada. Quando ela já tomava seu lugar à mesa, avisando Amande que teriam mais um convidado, Bob a surpreende convidando-a para jantar fora. Mostrando-se subitamente insegura, Nikita busca a aprovação da senhora, que a incentiva a aceitar o convite. A sequência sugere, deste modo, que essa é a primeira vez que Nikita deixa o local onde mora e no qual se dá o treinamento.

Bob parece cortejar Nikita: elogia sua figura quando a vê, oferece-lhe o braço ao saírem do prédio, abre-lhe a porta do carro que os leva ao restaurante onde, educadamente, espera que ela se acomode à mesa para depois sentar-se. A música que acompanha a cena não apresenta nenhum indício de tensão. Nikita parece, ao mesmo tempo, encantada com o lugar e pouco à vontade. Bob, ao contrário, revela-se um cliente costumeiro do elegante restaurante. Anunciando um truque de mágica, o agente retira a toalha que encobre um embrulho dourado e Nikita deixa-se seduzir pelo "presente". Leva as mãos em direção à face, morde os lábios de excitação, gestos que mesclam sensualidade e infantilidade. Bob lhe pede que espere o garçom servir-lhes o espumante antes de abrir o pacote e Nikita sorri pela primeira vez, feliz. Eles brindam ao seu futuro. Ao abrir a caixa de madeira e ver a pistola e a munição que ela abriga, o sorriso some-lhe da face. Bob, de maneira fria, dá-lhe as coordenadas de sua tarefa, a ser executada ali mesmo, assim que ele deixe o local. Ela parece sentir-se traída pelo agente, seus olhos enchem-se de lágrimas, mostra as sobrancelhas arqueadas e os lábios entreabertos de incredulidade. Ao ver-se sozinha na mesa do restaurante, contém o choro e volta a si rapidamente, mantendo o olhar alerta enquanto pega a pistola e o pente de dentro da caixa. Levanta-se e cumpre o que lhe fora designado, assassinando o alvo e o guarda-costas que o acompanhava no restaurante.

Antes de sair, Bob lhe passara instruções a respeito de como fugir do local, mas Nikita se vê completamente desamparada ao perceber que a janela do banheiro masculino por onde deveria escapar estava bloqueada. As lágrimas que correm por seu rosto contrapõem-se aos músculos delineados em seus braços e costas, recompondo a associação de sua figura à fragilidade - que agora já não aparece como um atributo físico, mas emocional - e força. Ela confronta-se com os demais seguranças que a perseguem até a cozinha do restaurante, mas consegue sair do prédio pulando pelo fosso 
do elevador de lixo em meio a um intenso tiroteio. Uma vez mais abandonada à própria sorte ao alcançar a rua e não encontrar o carro que deveria aguardá-la, o personagem tira os sapatos de salto alto em meio à chuva torrencial e corre em direção ao prédio que fora sua morada durante os anos anteriores. A chuva que cai sobre seu corpo na noite escura não só marca o fim do rito, purificando-a, mas anuncia também mais um recomeço, preparando-a para um novo renascimento e para a nova etapa de sua jornada. De acordo com José Carlos Bruni, "as coisas não só se dissolvem na água, elas também nela desaparecem. A purificação é a anulação do impuro, do pecado e do mal; é a anulação do passado. A água é símbolo de vida e de morte" ${ }^{, 52}$.

Sem que ninguém a reconheça, ela tem que agredir um segurança e gritar com o outro para conseguir entrar. Bob a espera em seu quarto, lendo jornal. Ela está molhada e ferida, suas meias estão rasgadas e sua maquiagem borrada. Ao dar-se conta de que as dificuldades que encontrara para deixar o local haviam sido premeditadas, tomada pela ira e pela mágoa, ela novamente o ataca. Ele então lhe revela que sairá no dia seguinte, uma vez que o rito de iniciação fora cumprido. Numa reação inesperada, Bob também se descontrola e confessa que sentirá saudades dela. A sequência termina com Nikita fechando-lhe a porta na cara, após beijá-lo suavemente nos lábios e anunciar que nunca mais o beijaria de novo. Surpreendido pela maneira com que Nikita aproximara-se dele e o recusara, Bob recosta-se na parede com lágrimas nos olhos ${ }^{53}$.

$\mathrm{O}$ rito de iniciação que essa missão simboliza constitui-se também em mais um momento de desestruturação para Nikita. Passados três anos, a fábrica convertera-se em seu lar e é lá que ela se mostra confortável e segura. Amande, por um lado, personifica esta mudança, e a intimidade construída entre as duas deixa ver que a professora transformara-se numa figura materna para Nikita, algo que a contraposição entre o aposento de Amande e os demais espaços da fábrica já antecipara. Ali, suspende-se a aparência fabril que predomina nos demais cenários, assemelhando-o ao espaço de uma casa. Não por acaso, portanto, Nikita busca o ninho que o aposento de Amande representa ao aceitar o treinamento e lá reaparece após sua metamorfose. Quando Bob a convida para sair, é na professora que a protagonista busca amparo para aceitar, como se estivesse pedindo-lhe autorização. Por outro lado, ao regressar à fábrica depois da

52 Bruni, José Carlos. "A água e a vida”. In: Tempo Social - Revista de Sociologia da USP, São Paulo, 5 (1-2), 1993, p. 62.

53 Ainda que esta sequência sugira um envolvimento emocional entre Bob e Nikita, os demais encontros dos personagens serão construídos na mesma chave que as comemorações de aniversários, em que o personagem agrada Nikita, agindo de maneira pessoal, para depois demandar que ela seja funcional. Nikita só percebe a dinâmica do comportamento de Bob após sua missão em Veneza. 
missão, já não é para o aposento de Amande que ela se dirige, mas ao próprio quarto. A fábrica, convertida em espaço familiar durante os anos de treinamento, abriga seu próprio ninho. Assim, o cenário de seu quarto aparece novamente redecorado, como uma atualização do aposento da senhora. $\mathrm{O}$ branco das paredes aparece suavizado pela iluminação dos abajures e da luminária, dispostos em vários pontos do ambiente que mescla o calor do vermelho à sobriedade do preto e do azul. A aparição de seu quarto, onde nenhum objeto pode ser visto fora do lugar, converte-se na última confirmação de que Nikita crescera, tornara-se adulta. No entanto, este é o quarto que lhe é negado, aquele em que ela não poderá mais ficar. Nikita será novamente obrigada a renascer, agora fora da fábrica de agentes.

A protagonista é então liberada no dia seguinte, sendo-lhe concedido um período de seis meses para se estabelecer. O renascimento de Nikita como Marie Clément é mostrado de forma bastante breve. Nele, a associação do personagem com a transformação do espaço que habita permanece. A primeira tomada do apartamento que aluga, que ela qualifica como perfeito, mostra um ambiente deteriorado, com as paredes sujas e descascadas, inabitável. Ela recomeça, portanto, novamente do zero. Contudo, a contraposição com o espaço que ocupava durante o treinamento é evidente: o ambiente sujo e mal iluminado em nada remete à assepsia vista na primeira aparição de seu quarto na fábrica ou com o ambiente imaculadamente arrumado que deixara para trás.

A fase infantil deste renascer é também bastante breve. Nikita reaparece suja de tinta - numa indicação de que estava reformando o apartamento -, vestindo a mesma camiseta com que fora vista nas suas primeiras aulas na fábrica, fazendo compras em um supermercado. Sem saber o que comprar, ela imita uma cliente, colocando em seu carrinho uma grande quantidade dos mesmos itens que a mulher seleciona.

É nesta ocasião que Nikita encontra Marco pela primeira vez. O jovem que é caixa do supermercado onde ela faz compras parece um pouco irritado com o comportamento da jovem que, agitada, demonstrando uma ansiedade tipicamente adolescente, começa a jogar sobre a esteira uma série de produtos. Marco pergunta se ela tem pressa, porque sua registradora não está funcionando bem e a esteira está quebrada. O jeito de Marco chama-lhe a atenção e Nikita se acalma, dizendo-lhe que tem todo o tempo do mundo. A partir daí, os dois começam a flertar. Ele conta que começara a trabalhar ali há três dias e que achava o trabalho complicado, revelando-se, assim, um homem simples, mas que ao realizar seu trabalho com desenvoltura, tenta valorizar-se diante dela. Simpático, arranca-lhe sorrisos. Marco parece conduzir a 
conversa até que Nikita, repentinamente, convida-o para jantar naquela mesma noite, após o trabalho. Ao contrário do que se poderia imaginar, não há nenhum romantismo durante o jantar à luz de velas que acontece em meio à reforma. Sentados frente a frente à mesa improvisada no chão do apartamento, Nikita come o ravióli com pressa, Marco tenta em vão puxar conversa, sem saber como agir e o que esperar. Ao suspender as regras do romance, dizendo diretamente a Marco o que quer, Nikita anuncia que será ela a conduzir a relação. Marco rende-se, advertindo-lhe apenas para não começar nada que não possa parar. Um fade in, construído a partir da imagem dos dois se beijando no chão do apartamento que aparece desde o teto, leva o espectador ao apartamento arrumado, depois da reforma, e a Nikita despertando na cama do casal, seis meses depois. Assim, é através de sua relação com Marco que Nikita se reinventa nesta parte da narrativa.

Este fade in dá início à quarta parte do filme, apresentando o período em que Nikita vive uma "vida dupla". Como Marie Clément, enfermeira, ela divide o apartamento que alugara com Marco, com quem se relaciona até o fim do filme. Como Joséphine, ela cumpre suas missões como agente da inteligência francesa ${ }^{54}$.

De acordo com Bordwell, não raro, como acontece nesta parte da narrativa de Nikita, a trama clássica hollywoodiana constrói

uma estrutura causal dupla, duas linhas de enredo: uma que envolve o romance heterossexual (rapaz/moça, marido/mulher), e outra que envolve uma outra esfera - trabalho, guerra, missão ou busca, relações pessoais. Cada linha possui um objetivo, obstáculos e um clímax. (...) Na maioria dos casos, a esfera do romance e a outra esfera são distintas, porém interdependentes. A trama pode finalizar uma das linhas antes da outra, mas é comum as duas coincidirem no clímax: a resolução de uma deflagra a resolução da outra ${ }^{55}$.

É exatamente desta maneira que a última parte da narrativa de Nikita é

54 A Nikita são atribuídos, assim, nomes latinos de grande significado para os cristãos. Marie é derivado do nome de origem hebraica Miriam, e tem vários significados, entre eles: rebelião, amargura, mágoa, aquela que deseja uma criança e senhora do mar. Joséphine é a forma feminina de Joseph ou José, também de origem hebraica, que significa aquele que acrescenta. O sobrenome Clément é originalmente um nome masculino de origem latina, cujo significado é o mesmo de seu cognato em português.

55 Bordwell, David, "O cinema clássico hollywoodiano: normas e princípios narrativos”, op. cit., 2005, pp.208-281. 
construída. Passado o período de adaptação, começam a ser atribuídas à protagonista suas missões como agente. A primeira e a segunda são construídas a partir de um telefonema em que Nikita escuta a voz de um homem chamar por Joséphine, seu codinome. Nas duas vezes em que o personagem recebe as chamadas, são interrompidos momentos de intimidade entre ela e Marco, o que sugere a tensão que se estabelece, na narrativa, entre a vida privada da protagonista e sua função como agente da inteligência. Nestas duas ocasiões, Nikita é tomada de surpresa. Sua primeira missão após o fim do treinamento não apresenta, entretanto, grande dificuldade. Nikita é enviada a um hotel onde, vestida de camareira, leva uma bandeja com escutas para um hóspede. Ela comemora o sucesso da missão fazendo compras e convidando Bob, que lhe telefona para cumprimentá-la, para jantar e conhecer Marco - uma maneira de satisfazer o companheiro, que estranhara ela não lhe ter apresentado nenhum familiar ou amigo durante o período em que estavam juntos. No jantar, Bob, passando-se por tio de Marie, oferece ao casal uma viagem à Veneza como "presente" de noivado. Como ocorre durante o rito de iniciação, Nikita é traída por Bob. O "presente" revela-se, assim, um pretexto para levá-la até o local onde executa sua próxima missão, assassinando uma mulher da janela do banheiro do quarto de hotel onde o casal está hospedado.

A missão em Veneza é dramática. Trancada dentro do banheiro da suíte, fingindo tomar banho, Nikita conversa com Marco, que está do outro lado da porta, num momento em que o personagem volta a indagar sobre seu passado, logo após confessar - para o espectador - que jamais esperara dividir a vida com uma mulher como ela. Nikita se desespera, uma vez que não é o passado que a assombra, mas o presente. A sequência reforça algo que o jantar com Bob já sugerira: Nikita troca de nome, mas não de história. Ao invés de criar um passado para sua nova identidade - como faz Bob ao inventar uma história sobre a infância de Marie para Marco durante o jantar -, ela simplesmente tenta esconder a sua própria trajetória, convertida em tabu ${ }^{56}$. Marie nada mais é que uma máscara que Nikita usa para tentar esconder sua identidade, o que causa, por um lado, as suspeitas e as preocupações de Marco e, por outro, sua incapacidade de impedir que sua profissão interfira na sua relação com o noivo. Sua "vida dupla" só existe na precariedade de seu segredo, que se mostra, então, uma fonte de tensão e angústia. A preocupação de Marco a respeito da ausência de amigos e

56 É Marco que começa a criar um passado imaginado para Marie. Quando tenta arrancar-lhe a verdade em Veneza, o personagem confessa: "Tenho imaginação, certo? E imagino o pior. E o pior seria um alívio". 
familiares e do passado nunca mencionado por ela, propõe uma incompatibilidade entre o relacionamento amoroso e o exercício da profissão de Nikita que não é visto na tela, mas que anuncia uma possível separação do casal. Apesar disso, Marco a trata como uma rainha e sonha poder dar a ela o tipo de vida que acha que ela merece. Para isso, pede demissão do supermercado para dedicar-se a projetar barcos. Marco busca, assim, tornar-se um homem melhor para a mulher que ama. Já Nikita, ao mesmo tempo em que revela uma ingenuidade a respeito de suas atribuições, visível na maneira como Bob a engana, demonstra que não é a profissão que atribui sentido a sua vida, mas sim sua relação amorosa com Marco. Contraditoriamente ao que se espera, contudo, a separação do casal não é causada pela descoberta do segredo de Nikita pelo noivo, mas pela escolha da protagonista em desertar após o roubo de informações de uma embaixada, sua terceira missão.

A missão, que fora planejada por Nikita durante vários meses, sai completamente fora de seu controle no momento de sua execução. No apartamento em que mantém o embaixador Maximilien Jedreck ${ }^{57}$ sedado, Nikita é informada de que o código de segurança que ele usava com seus guardas mudara repentinamente. Contra sua vontade, a missão é mantida e um "limpador", Victor, é mandado ao local. Nikita acredita que poderá convencê-lo a não assassinar o embaixador e os seus guarda-costas, mas desiste ao vê-lo chegar arrastando os corpos dos dois seguranças. Sem saber que o embaixador estava apenas desacordado, Victor pede ajuda ao seu sósia para colocá-lo na banheira junto com os corpos dos outros dois homens. Ao verem Victor abrir uma maleta contendo vários vidros com ácido, Nikita e o sósia do embaixador tentam intervir, mas ele não lhes dá ouvidos. O "limpador" joga o conteúdo dos vidros sobre os homens e o embaixador começa a debater-se na banheira. Nikita e o sósia se desesperam com o grotesco da cena, enquanto Victor continua jogando ácido sobre o homem para acelerar o processo. Em pânico, o sósia desiste da missão e atira em Victor, que o mata em seguida. Nikita diz a Victor que acha melhor comunicar-se com a central para saber quais serão as próximas ordens, mas ele a ameaça, dizendo que não aborta missões em progresso. Os dois dirigem-se então à embaixada e Nikita, passando-se pelo embaixador, consegue parte das informações que eram o alvo da missão. Surpreendida por um cão de guarda que entra no escritório em que estava, Nikita deixa o local antes

57 Jedreck é um nome masculino de origem polonesa e significa força. Apesar da narrativa não explicitar a que país a embaixada que Nikita invade pertence, a grande bandeira em que se vê uma estrela vermelha e o busto que aparecem na entrada do prédio remetem a algum país relacionado à antiga União Soviética. 
da hora marcada com Victor, que a aguarda do lado de fora. Chorando, ela lhe implora para deixarem o local sem que ele termine a "limpeza", mas ele insiste, atirando no funcionário da embaixada que saíra do prédio perguntando o que havia de errado. Nikita chegara ao seu limite. Ela esbofeteia Victor, tentando fazer com que ele volte a si, e corre para o carro, gritando para irem embora, enquanto as luzes de fora da embaixada se acendem e escuta-se o som do alarme disparado pelo guarda que o assistira atirar no funcionário pelo sistema de monitoramento. Victor ainda mata vários guardas antes de conseguir entrar no carro, mas é ferido várias vezes por um deles. Dizendo a Nikita que darão uma volta antes de terminar a missão, eles conseguem sair da embaixada arrebentando com o carro a parede do fundo de sua garagem. Victor morre pouco depois, ao parar o carro num farol de trânsito. Ao perceber que o "limpador" morrera, Nikita suspira aliviada. A missão, que deveria ser concluída sem nenhuma morte, termina, assim, tendo a protagonista como única sobrevivente.

A figura do "limpador" apresenta-se, dessa forma, como a antítese do herói que salva a mocinha. A aparição de Victor é decisiva para a deserção de Nikita. Sua atuação deixa evidente que sua vida, que é propriedade do Estado, não tem para ele valor algum. Como ratos de laboratório, os agentes são descartáveis. Não há quem possa protegê-la. Nikita retorna, então, aos braços de Marco. Seu noivo conta-lhe que sabe de tudo e pede-lhe que ela pare antes que seja tarde demais. A revelação de Marco é igualmente decisiva para o último renascimento de Nikita na narrativa. Decidida a desertar e liberta da máscara de Marie Clément, Nikita, finalmente, compartilha seu momento de maior intimidade. Os acontecimentos daquela noite constituem-se, dessa maneira, no momento da mais profunda ruptura para a protagonista, um momento de morte das identidades forjadas durante seu processo de pacificação. Ao decidir desertar, contudo, Nikita avança pela primeira vez, realiza o impossível, torna-se autônoma. De acordo com José de Souza Martins,

só pode desejar o impossível aquele para quem a vida cotidiana se tornou insuportável, justamente porque essa vida já não pode ser manipulada. (...) É no instante dessas rupturas do cotidiano, nos instantes da inviabilidade da reprodução, que se instaura o momento da invenção, da ousadia, do atrevimento, da transgressão. E aí a desordem é outra, como é outra a criação ${ }^{58}$.

58 Martins, José de Souza. A sociabilidade do homem simples: cotidiano e história na modernidade 
Assim, o último renascimento de Nikita na narrativa é um recomeçar qualitativamente diferente dos demais. Ela não só se tornara adulta, mas, finalmente amadurecera. O desfecho do filme mostra Marco recebendo a visita de Bob após sua deserção, em que ele entrega ao agente o material roubado pela protagonista como meio de garantir sua liberdade. Na última sequência do filme, Marco tanto aproxima a experiência de Nikita a uma punição severa quanto explicita a relativização que se iniciara na delegacia, identificando os homicídios que Nikita cometera em nome do Estado ao assassinato do policial ${ }^{59}$.

Assim, a narrativa de Nikita estrutura-se em torno de dois grandes desafios. O primeiro é a própria sobrevivência da protagonista, transformada em questão de Estado. O Estado aparece através de várias de suas instituições, como a polícia, o sistema judiciário e o de inteligência. Em relação a este último, Bob constitui-se no seu representante mais próximo a Nikita, supervisionando sua inserção como agente. Contudo, sabemos que não é ele quem decide o destino do personagem, uma vez que é visto reportando-se a um superior. Ele parece nutrir por Nikita uma variedade de sentimentos, no entanto, ela não aparece como sua protegida. Ele lhe omite informações, engana e manipula, alguém que parece ter sempre outras intenções por trás de suas ações. Neste sentido, ele encarna o Estado proposto pela narrativa, um Estado que só revela o que espera no último momento, através de uma voz sem nome. Um Estado que, apesar disso, se mostra incapaz de evitar que as situações fujam de seu controle, mas que não deixa de realizar-se.

Já Amande aparece como um modelo para Nikita, não apenas porque propõe uma certa feminilidade que é incorporada pela protagonista, mas também porque se apresenta como um exemplo do que Nikita pode se tornar no futuro, caso trilhe o caminho que lhe fora imposto, e que Amande também trilhou. Tal proposição se dá

anômala. São Paulo: Hucitec, 2000, pp. 63-64.

59 Traça-se, a partir de Nikita, um diálogo interessante com Laranja Mecânica. Ao fim do processo de pacificação dos dois personagens, Nikita e Alex, parece haver uma identificação entre a violência praticada pelos personagens e a violência praticada pelas instituições que se destinam a dominá-la. De acordo com Menezes, "se todas estas violências equivalem-se, sem que exista uma valoração relacional e diferencial entre elas, aparentemente estar-se-ia justificando e, no limite, glorificando, a existência e a aceitação desta violência individual que ele [Alex] antes executava”. Menezes, Paulo, $\grave{A}$ meia-luz, op. cit., 2001, p. 76. Menezes, contudo, vai além. Para ele, Alex é um dissidente, de modo que o filme de Kubrick "mostra as várias tentativas de domesticar esta dissidência, pelos mais variados meios e caminhos que, curiosamente, mostram-se todos repulsivos, tanto em seus métodos, quanto em seus resultados". Menezes, Paulo, op. cit., 2001, p. 77; grifos meus. A diferença entre a pacificação de Alex e Nikita reside neste efeito de repulsa que o filme de Kubrick constrói através de seus múltiplos estranhamentos e que o filme de Besson não é capaz de construir. 
através da referência às mãos de Amande - mãos que a denunciam - e de Nikita - mãos que precisam de proteção, que não podem envelhecer. Dessa forma, Nikita é um personagem que se constitui em relação ao tempo que é o de sua própria juventude: um tempo presente, que se perpetua como processo de amadurecimento contínuo e, um tempo futuro, invisível e negado aos olhos do espectador, mas anunciado pela única escolha autônoma que o personagem é capaz de fazer: deixar Marco e desertar, saindo de cena para sempre. A linearidade da estrutura narrativa de Nikita, neste sentido, sempre direcionada a este futuro desconhecido - ainda quando elementos narrativos estabelecem as relações de causalidade ou apontam para os acontecimentos mais ou menos previsíveis do enredo, como o tiroteio na farmácia ou o fim do relacionamento de Nikita e Marco - apresenta-se como uma forma cinematograficamente eficaz de construir o tempo próprio à juventude, que é o tempo de sua protagonista.

Apesar disso, seu comportamento preserva uma certa infantilidade, que pode ser vista tanto através da maneira como faz as primeiras compras no supermercado, quanto na lingerie estampada com pequenas flores que aparece na primeira sequência após sua transformação e na sequência da missão em Veneza. É a mistura composta por sua imaturidade e juventude e pela maneira com que realiza a violência em suas missões que atribui grande ambiguidade ao seu personagem. As lágrimas que ela não consegue conter toda vez que se frustra ou se sente pressionada relativizam seu comportamento violento, fazendo com que ela se apresente como uma mulher forte e frágil que sobrevive à violência e através dela sem que, ao fim, seja possível atribuir bondade ou maldade aos seus atos.

Amadurecer, chegar a este ponto de sua história em que decide seu destino, constitui-se, então, no segundo e primordial desafio proposto pela narrativa a sua protagonista. Se durante a primeira parte da narrativa Nikita se apresenta como uma jovem rebelde e violenta, durante a quarta parte ela se mostra um personagem mais adaptado, capaz de realizar o que lhe é incumbido e tornar-se "o complemento" de Marco.

A ideia da complementaridade dos gêneros constitui-se como uma das bases da estrutura social moderna. No imaginário sobre o casal complementar - geralmente heterossexual e monogâmico, como é o de Nikita - a complementaridade não está presente apenas em relação ao amor, ao sexo e às próprias concepções do que é masculino e feminino, mas também em relação à violência. É em relação ao imaginário da complementaridade que a violência aparece como uma atividade masculina. De 
acordo com Hilary Neroni, a mulher, por sua vez, aparece como sua vítima, tanto literal quanto metaforicamente.

A violência masculina é justificada, com frequência, no fato de que os homens são violentos para proteger as mulheres (ou para destruir a masculinidade de outros homens). Essa é a relação tradicional que a mulher tem com a violência - como alguém que dela é protegida ${ }^{60}$.

Neste sentido, é o próprio processo de pacificação de Nikita que instaura nela o conflito interno: ao "tornar-se mulher" segundo os padrões civilizados de comportamento e sentimento, a realização de sua violência converte-se em sofrimento, transforma-se em um problema pessoal, identitário. Dessa maneira, ao renascer como "complemento" de Marco, o exercício de suas funções como agente e seu relacionamento amoroso só podem ser construídos a partir desta tensão em relação à complementaridade dos gêneros. Mesmo que Marco não a julgue pelo seu passado e pelo que ela fora obrigada a tornar-se, a ideia de que ele deveria protegê-la faz-se presente pela referência à fragilidade de suas mãos. Neste momento, é ele quem sugere um retorno aos padrões de complementaridade em relação à violência, desestruturados pelo fim do segredo. Contudo, Marco deixa de ser o refúgio possível de Nikita ao revelar-lhe que sabe o que ela tentara dele esconder. Assim, a autonomização de Nikita não pode ocorrer de forma completa a não ser que ela deserte e o deixe. O outrofeminino que, por fim, nasce de sua autonomia, problematiza a imediata associação entre fragilidade e doçura em relação à imagem da mulher, rompendo com a concepção de que tais atributos constituem-se como fundamento de sua não-violência e colocando em evidência os termos de complementaridade dos gêneros em relação ao exercício da violência. Ao fazê-lo, instaura-se, assim, a possibilidade do questionamento, pelo espectador, não apenas da "apropriação" da violência pelo feminino, mas, também, de um dos fundamentos da relação entre os gêneros e do próprio modelo que se baseia na sua complementaridade. Em última instância, o que Nikita coloca em xeque é $o$ modelo. Em menos de uma década após seu aparecimento, começa a pronunciar-se também uma problematização sobre as maneiras de se debruçar sobre ele, um movimento de suma importância na tentativa de compreensão das questões que emergem a partir de

60 Neroni, Hilary, The violent woman, op. cit, 2005, p. 92; grifos da autora. 
personagens como Lara Croft, tema do capítulo seguinte. 


\section{Capítulo IV - Lara Croft}

A chegada aos cinemas do personagem do jogo eletrônico Tomb Raider, se deu por meio da criação de uma história que, ao mesmo tempo em que conta uma das aventuras de Lara Croft, constrói suas origens e propõe um processo de desenvolvimento pessoal. Liberto das amarras das origens, o segundo filme da série vai buscar no relacionamento da protagonista com novos personagens sua consolidação como heroína. Dessa maneira, este capítulo dedica-se a analisar os elementos que fazem com que Lara apareça como um dos personagens que reelaboram a relação entre heró́smo e feminino no cinema da primeira metade dos anos 2000.

\section{SEXo, VIOLÊNCIA E PODER EM LARA CROFT}

Pode-se dizer que as apresentações dos dois filmes da série Tomb Raider são construídas numa chave diferente daquela mais comumente utilizada na narrativa tradicional, que é a de indicar com quem, como, onde, quando e por que se desenvolverá o enredo, por meio de um conjunto de sequências de curta duração ${ }^{1}$. A apresentação, nestes casos, apontaria a temática geral da narrativa, preparando o espectador para o que se desenrolará em seguida. Nos dois filmes da série, ao contrário, esta breve apresentação do problema é substituída por um bloco de ação estendido, que mobiliza elementos da história propriamente dita enquanto apresenta o desafio a ser superado por Lara Croft. Esta opção na construção das narrativas atribui dinamismo às histórias, potencializando o sentido de aventura a respeito do que se passa na tela.

Tanto Lara Croft: Tomb Raider (Simon West, 2001) quanto Lara Croft Tomb Raider: A Origem da Vida (Lara Croft Tomb Raider: The Cradle of Life, Jan de Bont, 2003) apresentam estruturas narrativas similares no que se refere à construção de

\footnotetext{
A apresentação da narrativa clássica estabelece, neste sentido, o microcosmo espaço-temporal da história, instaurando o princípio de causalidade que a orienta. Nos termos de David Bordwell, constitui-se por um estágio inicial de coisas, cujo equilíbrio será violado durante o desenvolvimento do enredo e restabelecido no seu desfecho. Cf. Bordwell, David, "O cinema clássico hollywoodiano: normas e princípios narrativos", op. cit., 2004, p. 279. De acordo com Ismail Xavier, este microcosmo projetado se propõe como réplica em relação ao mundo fora da tela, e a construção do discurso que o cria ancora-se, ao mesmo tempo, em um efeito de janela - pela qual o microcosmo pode ser visto - e um efeito de anterioridade - como se os eventos que nele se passam independessem da câmera que os capta. Cf. Xavier, Ismail, O discurso cinematográfico, op. cit., 2005, p. 62. Como abordado no Capítulo II, um esquema similar (equilíbrio inicial - desequilíbrio - equilíbrio final) se faz presente
} 
grandes blocos de ação que se apresentam, também, como as partes que integram as narrativas. Assim, o primeiro bloco de ação introduz alguns personagens e o desafio que deverá ser enfrentado por Lara. A partir daí, surgem outros blocos de ação, geralmente relacionados a recortes espaciais diferenciados, montados a partir de um paralelismo ininterrupto entre as ações de Lara e seus associados e as ações de seus adversários. Lara e seus rivais reúnem-se na última parte das duas narrativas, que culmina na solução de cada um dos desafios iniciais.

Apesar disso, a primeira sequência de Lara Croft: Tomb Raider merece destaque neste contexto. Se a primeira parte do filme propõe o desafio que guiará a trama, esta sequência em particular dá destaque à protagonista.

Como se saísse de dentro de seu olho, a câmera se distancia até mostrar sua face num close-up. A câmera gira e se afasta, mostrando-a pendurada de cabeça para baixo por uma corda, no que parece ser um templo egípcio. Em seguida, um plano curto de um objeto de metal disposto sobre um pedestal de pedra mostra seu objetivo. Ela lançase ao chão num perfeito salto mortal duplo. A exatidão de seus movimentos mostra sua destreza e preparo físico. Lara sai correndo pelo ambiente à procura do objeto. Os tambores e os "trovões" que se ouvem colaboram na proposição de uma sensação de tensão que predomina até o momento em que, ao som de flautas, ela se aproxima dele. Lara diminui o ritmo, de modo a que o sentido de urgência de sua empreitada seja substituído por uma atitude de desejosa prontidão: caminha com cuidado e silenciosamente, mantendo as mãos próximas às pistolas. Ela aparece ora através de close-up $(s)$ de seu rosto que exibem seus lábios entreabertos, ora por meio de planos americanos $^{2}$ de seu quadril e coxas. Sobre o preto da camiseta e do short curto que veste, vê-se a caveira forjada no fecho de metal do cinto. Dele, dois pentes de munição pronunciam-se em cada lado de seu corpo, rompendo o desenho de sua silhueta. Tiras negras unem o cinto aos coldres das duas pistolas que carrega, presos às coxas dela por ligas de couro também preto. Esta cinta-liga única, reinventada, impregna de sensualidade o duelo que se anuncia. O modo como Lara é mostrada, portanto, lembra a maneira como aparecem os heróis de faroeste, mas também traz elementos que remetem à figura da dominatrix, principalmente no que se refere à predominância do preto e à presença da cinta-liga em seu figurino. Se, como diz Edgar Morin, "a virilidade do herói

também no melodrama griffthiano.

2 Segundo Xavier, o plano americano "corresponde ao ponto de vista em que as figuras humanas são mostradas até a cintura aproximadamente, em função da maior proximidade da câmera em relação a 
é introjetada no uso da pistola do justiceiro do faroeste, que preserva a sua antiga e maravilhosa infalibilidade"3, a maneira como a sensualidade da heroína de Tomb Raider é construída tem profunda relação com os modos pelos quais ela realiza a violência.
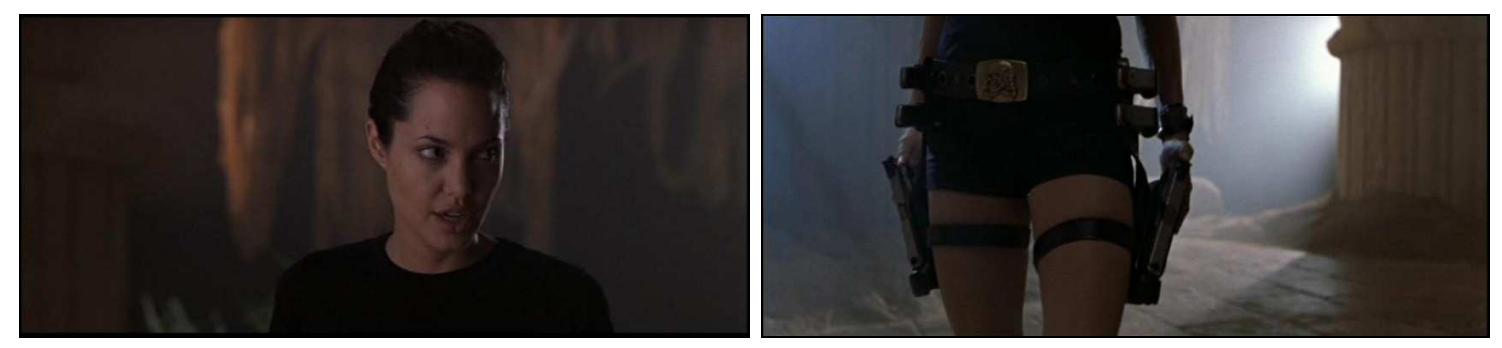

A coluna que tem a seu lado treme, anunciando que Lara não está sozinha. Um imenso robô salta à frente dela, arrancando um pedaço da coluna com um golpe. O robô se movimenta às vezes como um humanoide, por vezes como um inseto. Com outro golpe, ele lança Lara no chão. Ao sentar-se, seu rosto aparece tomado pela raiva. A trilha sonora, composta por uma música eletrônica, impõe ritmo ao enfrentamento que se seguirá. Ruídos de disparos e de escombros do templo ruindo são ouvidos em meio aos gemidos da protagonista. O que se vê, então, - bem como em outras sequências de luta durante as narrativas - é a execução de uma coreografia acrobática e meticulosa do combate que, neste caso, destina-se a exibir as habilidades de Lara.

O ponto de vista do robô é contraposto ao de Lara através da utilização de imagens que remetem à interface de um programa de computador: nela, ela aparece em preto e branco sobre um fundo negro esverdeado. Como geralmente acontece na filmagem de diálogos, o esquema de montagem que propõe a contraposição dos pontos de vista de Lara e do robô, estabelece-se pelo uso do que se convencionou chamar de campo/contra-campo. Nele há a combinação de duas estratégias que amplificam a identificação do espectador e a impressão de que ele participa da cena: a câmera subjetiva $^{4}$ e o shot/reaction shot ${ }^{5}$. Numa situação construída a partir da utilização do

ela". Xavier, Ismail, op. cit., 2005, p. 27.

3 Cf. Morin, Edgar, As estrelas, op. cit., 1989, pp. 14-15

4 Segundo Ismail Xavier, a câmera subjetiva assume o ponto de vista de um personagem, a partir de um posicionamento que gera a sensação que se vê com seus olhos. Cf. Xavier, Ismail, $O$ discurso cinematográfico, op. cit., 2005, p. 34. Contudo, a utilização da câmera subjetiva nem sempre se faz evidente, como nesta sequência; “(...) em boa parte das situações em que ela é utilizada, o fato de que o espectador observa as ações através do ponto de vista de uma personagem permanece fora do alcance de sua consciência. É neste momento que o mecanismo de identificação torna-se mais eficiente (não surpreende que seu uso sistemático seja nos momentos de maior intensidade dramática). Nosso olhar, em princípio identificado com o da câmera, confunde-se com o da personagem; a partilha do olhar pode saltar para a partilha de um estado psicológico, e esta tem caminho aberto para 
campo/contra-campo, a câmera ora assume o ponto de vista de um personagem, ora de outro, alternando os pontos de vista de cada um deles. Deste modo, o campo/contracampo lança o espectador para dentro do espaço da interação. Segundo Ismail Xavier, o espectador “(...) ao mesmo tempo, intercepta e identifica-se com duas direções de olhares, num efeito que se multiplica pela sua percepção privilegiada das duas séries de reações expressas na fisionomia e nos gestos" ${ }^{\prime 6}$ dos personagens envolvidos na situação. Aqui, como acontece em outras narrativas que contrapõem o olhar de um personagem ao "ponto de vista" de uma máquina, para que o mecanismo de identificação se realize faz-se necessário tornar explícita a construção do campo/contra-campo. O efeito da utilização de imagens esteticamente diferenciadas em relação ao mecanismo de identificação é bastante interessante. De um lado, há uma plena identificação do ponto de vista da câmera com o olhar humano. Do outro, as imagens propõem exatamente o contrário, uma ruptura. No caso do robô, é justamente esta ruptura que humaniza seu ponto de vista.

De volta ao combate, Lara evita que o robô a acerte, abrindo as pernas sobre o chão. Saltando para trás, põe-se novamente em pé, já empunhando as duas pistolas. Os músculos tensionados de seus braços reiteram sua força e preparo físico. Lara descarrega as pistolas, atirando sobre o robô que dela se aproxima. Ela salta pelo templo, rola no chão até proteger-se atrás de um bloco de pedra esculpida, e as recarrega. Os gemidos de prazer presentes na música utilizada na sequência sugerem que a luta aparece como um substituto da relação sexual. Assim, a associação entre sexo e violência que é proposta pela narrativa reconstrói o sexo como uma luta que dá prazer, de modo que sexo e violência alimentam-se mutuamente, confundem-se, transformando-se de um em outro.

O robô atinge o bloco de pedra e Lara novamente se afasta, ganhando distância para atirar. Com extrema precisão ela divide uma corda com um disparo, soltando o grande pedaço de tecido que cai sobre o robô, como um lençol, e liberando o pedaço de corda preso ao teto que ela usa para saltar novamente para longe dele. Vendo que o robô

catalisar uma identificação mais profunda diante da totalidade da situação”. Xavier, Ismail, op. cit., 2005, p. 35; grifos do autor.

5 Já o shot/reaction shot explicita o efeito (geralmente psicológico) do que acontecera num plano anterior no comportamento de um personagem. A inversão deste esquema, de acordo com Xavier, resulta numa das combinações mais eficientes da câmera subjetiva com o shot/reaction shot. Neste caso, primeiro vê-se que o personagem observa algo para, então, a câmera assumir seu ponto de vista. Cf. Xavier, Ismail, op. cit., 2005, p. 34.

6 Xavier, Ismail, op. cit., 2005, p. 35. 
logo se libertaria, ela dispara repetidas vezes sobre uma coluna à frente dela. A coluna cai sobre o robô quando Lara salta sobre ela, prendendo-o novamente. O objeto reaparece ao fundo do templo, em frente à coluna sobre a qual ela agora caminha, sugerindo a vitória de Lara. O robô, no entanto, reage, surpreendendo-a ao desprenderse. Lara lança-se em direção ao solo, reaparecendo ao fundo, em pé, com as pernas afastadas, posicionada para o duelo final entre os dois. Um outro plano mostra, com a câmera deslocando-se por detrás da abertura de suas pernas, o robô, à frente dela, também tomando posição de combate.

Através de planos paralelos, os dois personagens mostram suas armas, provocando-se mutuamente. A câmera fixa-se nas pistolas, negras como o figurino de Lara, e nos tentáculos metálicos do robô, com suas lâminas em movimento. Os dois correm, então, um em direção ao outro. Lara joga-se no chão por entre as pernas do robô "sem sexo", , atirando sem parar. A câmera que mostra seus movimentos desde cima gira quando ela se volta para a direção de onde vem seu oponente, que salta sobre ela em seguida. A câmera se distancia, mostrando desde um plano baixo, Lara embaixo, com os joelhos dobrados, as pernas ligeiramente abertas e os braços estendidos na direção do robô, que se apóia no chão com os braços e pernas mecânicas ao redor dela. A posição dos dois já não esconde a proposição de que a luta simula uma relação sexual. Com a proximidade do robô, ela deixa as armas sobre o solo. Com as mãos, agarra os tentáculos da máquina, tentando impedir que as lâminas a atinjam, enquanto tenta afastá-la de seu corpo estendendo uma de suas pernas para cima, protegendo-se da "violação".
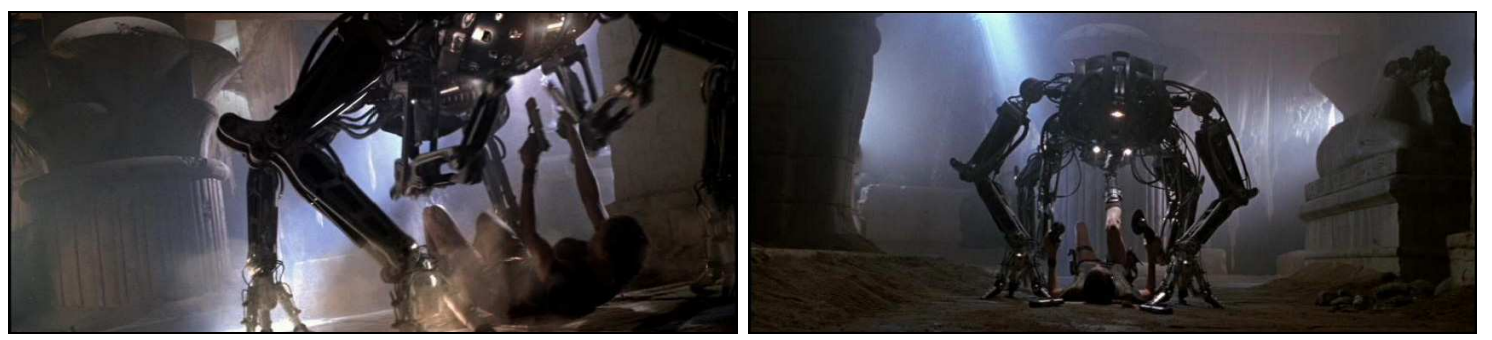

7 Não é curioso como não há surpresa alguma na revelação de que o robô se chama Simon? A força do imaginário que associa violência ao masculino se manifesta na projeção de um gênero para o robô e na projeção de que a relação sexual que a luta simboliza seja uma relação heterossexual. O filme, entretanto, reitera estas relações ao não mostrar Lara enfrentando nenhuma mulher. A única outra mulher que fala na narrativa é a camareira do hotel de Alex West em Veneza, que ao ver seu corpo nu reage à potência de seu sexo numa chave bastante tradicional. 
Durante a luta corpo-a-corpo, os gemidos e as feições de Lara exprimem não apenas seu esforço e sua força física, mas também prazer: seu rosto contrai-se e relaxa enquanto mantém os olhos estranhamente fechados e os lábios insistentemente abertos. É quando seus lábios carnudos deixam de mostrar os dentes travados que a proposição da sensação do prazer da violência emerge provocativamente através de sua figura.
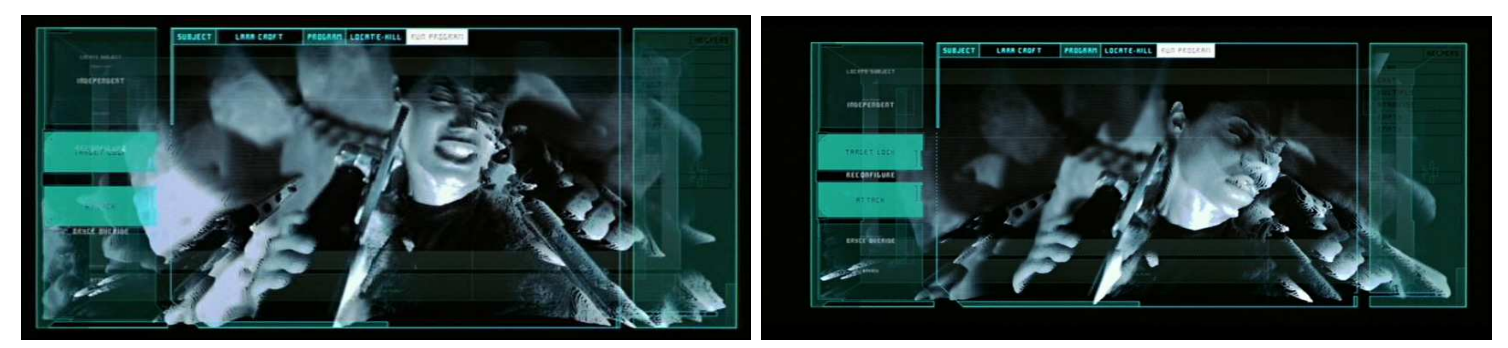

Quando Lara consegue cortar os braços do robô, de modo que suas lâminas fiquem presas no chão - tornando-o impotente -, ela inverte as posições. Em cima da máquina, ela bate com o cabo da pistola até conseguir abrir o compartimento de onde desentranhará seus fios que, ao serem desconectados, fazem com que o robô pare de funcionar. É ela quem, por fim, realiza, dessa maneira, a "violação". A música cessa quando Lara ergue o tronco, altiva. Com o robô dominado e inerte sob seus pés, suspira e ri. Seu corpo não emana nenhum temor, é puro prazer, já não restam dúvidas de que ela vencera mais uma vez.

Em seguida, revela-se que tudo de fato não passara de um treino e o que se acredita ser um templo egípcio é apenas um dos aposentos da Mansão Croft. Lara finalmente pega o objeto de cima do pedestal de pedra, seu objetivo fora cumprido. $\mathrm{O}$ robô estranhamente se levanta, como se tivesse a capacidade de consertar-se a si mesmo, mas ela, já satisfeita, ordena que ele pare com um gesto. O robô, agora numa postura explicitamente submissa, a obedece. Retirando um pente de memória de dentro do objeto - que só então aparece como uma caixa de acrílico transparente e não um artefato de metal -, Lara comemora sua vitória transformando o robô num tocador de mp3.

Dessa maneira, o duelo que é, ao mesmo tempo, faroéstico e futurístico, não tem outro tempo que senão o do simulacro, da encenação de um acontecimento ${ }^{8}$. O robô, que notadamente persegue Lara, não disputa com ela a posse do objeto, não se dirige a

\footnotetext{
${ }^{8}$ Cf. Chaui Marilena, Simulacro e poder, op. cit., 2006, p. 17.
} 
ele nenhuma vez, toda sua "atenção" autômata e automática está voltada para Lara. A sequência lembra, dessa maneira, o mundo do videogame, cujos adversários tratam de impedir a consecução do objetivo que levará o jogador para a próxima fase. Entretanto, o espectador só se dá conta do simulacro quando Lara ordena que o robô pare. Assim, o espectador vivencia, a partir da figura de Lara, o prazer que ela sente, deixando-se seduzir pelo personagem. Disso emerge sua força.

O engajamento de Lara neste combate fornece indicativos sobre como a violência se expressa nos filmes da série através de sua figura. Lara apresenta um físico que se exibe para a câmera: é ágil, domina seu corpo e suas armas com maestria. A câmera busca mostrá-las junto a seu corpo, como se dele fossem uma extensão. No entanto, Lara não hesita em livrar-se delas se necessário, o que mostra que a violência da protagonista não depende exclusivamente delas para realizar-se, como acontece frequentemente com personagens femininos fálicos, como Thana.

Considerando a sequência de Sedução e Vingança em que o marido traído "toma" a arma de Thana e a sequência da luta simulada em Lara Croft: Tomb Raider, a diferença entre os dois personagens torna-se evidente. No caso de Thana, a realização de sua violência ancora-se exclusivamente na posse do falo simbolizado pela pistola. A ideia de que o corpo da mulher é um corpo frágil - e, em decorrência, fraco e nãoviolento - devido a sua "natureza", opera, então, na sua totalidade. Thana, deste modo, é uma mulher fálica apenas enquanto e porque possui uma arma de fogo ${ }^{9}$. Ao perder este seu "acessório" definidor, ela volta imediatamente à condição "original". Sedução e Vingança descortina, portanto, os limites de uma mulher fálica construída nestes termos. Para além da associação entre violência feminina e loucura - ou subversão do "feminino" convertido, no plano simbólico, em masculino - está a reiteração de que o corpo feminino não é, por definição, violento, e de que ele pode ser violento apenas ao apropriar-se de um falo que não lhe é constitutivo. A violência que a mulher fálica

9 Importante salientar que o fálico não se manifesta exclusivamente pela posse de uma arma de fogo e que há diferenças qualitativas entre os objetos que assumem o lugar do falo. De acordo com Carol J. Clover, "Facas e agulhas, como dentes, bicos, presas e garras, são extensões pessoais do corpo que remetem aquele que ataca e aquele que é atacado a um contato primitivo, animalesco. Em $A$ vingança de Jennifer, ameaçando-o com uma arma, a protagonista força seu estuprador a arriar as calças, presumivelmente com a intenção de atirar em seus genitais. Ela, então, muda de ideia, convidando-o a ir com ela para sua casa, para aquilo que ele imediatamente supõe seria uma continuação voluntária do estupro de sua gangue, ocorrido antes. Lá, enquanto divide com ele a banheira, castra-o com uma faca. Se nos perguntávamos por que ela desistira da pistola, agora sabemos: todos os símbolos fálicos não são equivalentes, esfaquear responde ao estupro de um modo que alvejar, mesmo quando o ato é precedido pela humilhação, não é capaz”. Clover, Carol J., Men, women, and chain saws, op. cit., 1992 , p. 32. 
expressa é, assim, de uma fragilidade ainda mais acentuada que aquela atribuída ao seu corpo desprovido do "acessório".

Ao contrário de Thana, Lara não se "apropria" simplesmente da virilidade simbolizada pelas pistolas. No seu caso, as pistolas aparecem de fato como acessórios, inegavelmente importantes à consecução de seus objetivos, mas dos quais ela pode prescindir sem descaracterizar-se. Neste sentido, sua violência não se origina de algo que lhe é exterior, do seu equipamento, mas ela está entranhada em seu corpo, como os fios dentro do robô. O que o personagem de Lara deixa ver é ao mesmo tempo a manifestação de violência feminina construída a partir de termos diferentes daqueles em que se ancora a violência de personagens como Thana e, também, sua projeção a partir dos seios, sempre pontudos, rijos, firmes, símbolo de sua feminilidade e não de outra coisa, nem o substituto de algo negado pela "natureza". Assim, a primeira sequência do filme propõe um personagem forte, hábil e de grande apelo sexual. O que se desdobra desta caracterização é que o corpo de Lara não apenas pode ser desejado, mas temido, não porque se descaracterizou, mas porque se apresenta de uma maneira diferente. É deste modo que a associação entre sexo, violência e poder, em Lara, aparece quase que imediatamente para o espectador, através dos signos mobilizados nestes primeiros minutos.

Esta é uma construção que, no entanto, não aparece isenta de ambiguidades. Ao discutir como as demandas das mulheres nos relacionamentos com os homens os aterrorizam, Christopher Lasch sustenta que,

as demandas sexuais das mulheres aterrorizam os homens porque repercutem em níveis tão profundos da mente, evocando fantasias primitivas de uma mãe possessiva, sufocante, devoradora e castradora. A persistência de tais fantasias na vida adulta intensifica e traz à superfície o secreto terror que sempre foi parte importante da imagem masculina de feminilidade. A força dessas fantasias pré-edipianas, no tipo narcisista de personalidade, faz com que seja provável que os homens abordarão as mulheres com sentimentos irremediavelmente divididos, dependentes e exigentes, em sua fixação com o seio, mas aterrorizado pela vagina, que ameaça comê-los vivos; das pernas, que a imaginação americana dota a heroína, pernas que, presumivelmente, podem estrangular ou cortar as vítimas até a morte, do próprio seio perigoso, fálico, envolvido em armadura rija, que, no terror inconsciente, mais lembra um equipamento de destruição do que uma fonte de nutrição. (...) Menina ou 
mulher, esposa ou mãe, esta fêmea corta os homens em pedaços ou os engole inteiros. Ela viaja acompanhada por eunucos, por homens machucados, que sofrem de sentimentos inomináveis, ou por alguns homens fortes, derrubados por suas tentativas desorientadas de fazer dela uma verdadeira mulher. ${ }^{10}$

A maneira como Lara figura na primeira sequência coloca o espectador, neste sentido, em contato com uma mulher cuja aparência remete em muitos pontos à fantasia masculina proposta por Lasch. Segundo a concepção do autor, tal fantasia seria em parte elaborada na literatura e no cinema do século XX pela construção de personagens femininos cruéis e destruidores. Ao contrário disso, no entanto, Lara emerge ao fim dos dois filmes da série como imagem de justiça e heroísmo, atribuindo, dessa forma, um novo significado a essa imagem de mulher dominadora. Este novo significado se preserva mesmo quando se considera as profundas diferenças em relação ao destino dos ex-parceiros que aparecem nas duas narrativas, já que em Lara Croft: Tomb Raider ela salva Alex West, enquanto que em Lara Croft Tomb Raider: A Origem da Vida ela mata Terry Sheridan.

Se a estranheza da caracterização de Nikita como personagem feminino violento advém de sua aparente fragilidade, a de Lara emerge dos elementos que a aproximam da figura da dominatrix. Num conjunto de práticas sadomasoquistas, a dominatrix é a mulher que exerce o papel dominante na realização das fantasias de dominação e submissão. O lado dominatrix de Lara aparece nas narrativas através da mobilização de seus estereótipos mais conhecidos: o figurino negro da primeira sequência, a roupa de couro também negra com que vai à casa de leilões, a troca de "lugares" durante a luta com o robô e os momentos de intimidade sexual (o "ficar por cima", na falta de melhor denominação), as algemas com as quais ela prende Sheridan ao beliche, entre outras referências ${ }^{11}$. Tais estereótipos colocam a questão se um personagem como Lara não

10 Lasch, Christopher, A cultura do narcisismo, op. cit., 1983, pp. 248-249 e p. 250; grifos meus.

11 Tais estereótipos remetem à acepção de que, em práticas sadomasoquistas ocorre sempre uma inversão dos papéis "tradicionais" de gênero, o que pode até ser bastante comum, mas não é a única alternativa. Algolagnia (Túlio Bambino, 2006) apresenta o outro lado deste estereótipo ao mostrar também mulheres que adotaram o papel de "escravas", como uma forma de expressar o lado submisso de suas personalidades. Em certo sentido, Lara Croft: Tomb Raider relativiza a caracterização de Lara como dominatrix ao fazer referência ao lado dominador de Powell. Isto acontece na sequência que o mostra em sua tenda no Camboja, falando com Lara pelo telefone. Nela, uma mulher massageia suas costas com os pés (a podolatria figura, neste sentido, como um dos fetiches sexuais frequentemente associados às práticas sadomasoquistas). Um plano geral do interior da tenda, o segurança ao fundo, o Sr. Pimms parado ao lado direito da tela, à disposição de seu senhor, e outra mulher asiática imóvel, ajoelhada ao lado do leito onde Powell está deitado, segurando uma bandeja com frutas, olhando para baixo. As duas mulheres vestem túnicas de aspecto tradicional, cujos tons de vermelho combinam 
realiza, de outra maneira, a inversão simbólica operada pela mulher fálica, tomando o lugar imaginário que tradicionalmente pertenceria à masculinidade.

De acordo com Jeffrey A. Brown há, num nível fundamental, um espectro da dominatrix em todos os personagens femininos violentos contemporâneos, não no que poderiam remeter diretamente às práticas sadomasoquistas, mas no sentido em que relacionam, numa mesma figura, características que pertenceriam aos diferentes integrantes do par complementar ${ }^{12}$. Neste sentido, a dominatrix tal qual concebida por Brown é "um símbolo complexo, que combina e explora poderes físicos e sociais ao longo de um eixo de gênero que é tanto masculino quanto feminino"13. De acordo com este autor,
tanto a dominatrix quanto a heroína de ação ${ }^{14}$ combinam signos contraditórios: feminino e masculino, sujeito e objeto, potente e impotente, prazer e punição. Nos seus aspectos mais elementares, essas combinações podem representar uma ansiedade de castração para espectadores masculinos, mas nos seus aspectos mais progressivos, também demonstram a fragilidade da oposição de categorias culturais binárias. (...) Como a dominatrix, a heroína de ação (...) não apenas veste-se como homem ou simplesmente apresenta-se como masculino. Ela veste-se como homem e mulher, representando masculinidade e feminilidade. Neste sentido, ela ilustra não apenas que o gênero é primordialmente uma performance de determinados atributos e convenções culturais, mas também que estes atributos e convenções não têm que simbolizar diferenças sexuais. Os signos

com a cor da lona da tenda, também vermelha. A maneira como as duas mulheres aparecem na sequência apresenta-se, desta maneira, como uma clara referência a uma submissão feminina oriental. Utilizando um tom bastante amistoso com Lara ao telefone, Powell muda imediatamente de tom e de feição ao desligar o telefone e ordenar que sua massagista use de mais força. A caracterização de Powell como master realizar-se-ia de forma completa se a figurante tivesse respondido: "Sim, Mestre!".

12 Cf. Brown, Jeffrey A., "Gender, Sexuality and Toughness: The Bad Girls of Action Film and Comic Books", op. cit., 2004, p. 50-52.

13 Brown, Jeffrey A., op. cit., 2004, p. 69.

14 Segundo Elizabeth Hills, foi Yvonne Tasker quem cunhou a noção de heroínas de ação, de modo a chamar atenção para a construção dos aspectos heróicos atribuídos a certas protagonistas de filmes contemporâneos. A este respeito, ver: Tasker, Yvonne. Spetacular bodies: gender, genre and the action cinema. Nova Iorque, Londres: Routledge, 1993. Tais personagens, ao mostrarem-se agressivos e heróicos transgridem, de acordo com Hills, os códigos cinematográficos e culturais que posicionam os personagens femininos como personagens passivos, imóveis e periféricos no interior de narrativas hollywoodianas "de ação", ao mesmo tempo em que se apresentam como uma ruptura e um desafio à tradição que estabeleceu o herói como uma figura necessariamente masculina, desestabilizando qualquer certeza a respeito do que estes personagens podem fazer na tela e interrompendo uma leitura automática de seus atributos. Cf. Hills, Elizabeth, "From 'figurative males' to action heroines: further thoughts on active women in cinema", op. cit., 1999, p. 38 e p. 41. 
referentes à masculinidade e à feminilidade não são conjuntos completos, mas peças singulares com as quais se pode jogar ${ }^{15}$.

A nova figura que emerge desta relação, portanto, "é tanto sujeito quanto objeto, tanto olha como é olhada, é tão violenta quanto é objeto sexual", mesclando, deste modo, características que, tradicionalmente, seriam atribuídas ao feminino e ao masculino de forma exclusiva ${ }^{16}$. Deste modo, é da conjugação de símbolos do desejo e do temor, que se dá pela presença concomitante de um apelo sexual convencional e de habilidades violentas, que tais personagens emergem como dominatrixes ${ }^{17}$. A aparência reiteradamente sexualizada de personagens como Lara é central para o argumento de Brown que, imerso num debate sobre a predominância de aspectos progressivos ou regressivos destes personagens, problematiza a possibilidade de figurarem como simbolicamente masculinos. Neste contexto, Brown parece ter razão ao afirmar que,

enquanto travestir-se ou incorporar o gênero oposto é momentaneamente transgressor, fazê-lo ainda reinscreve atributos de gênero como a norma, como especificidades de gênero, porque estes atributos apresentam-se como mutuamente excludentes. Se a heroína de ação é um homem figurado, a importância de signos como músculos, independência, competência e controle, dentro de uma economia da masculinidade, não é realmente questionada, mas reforçada. Mas se a heroína de ação é lida como uma dominatrix, a exclusividade dos atributos de gênero é verdadeiramente problematizada, porque um conjunto de signos de gênero não substitui $o$ outro; ao invés disso, as fronteiras confundem-se porque são combinadas ${ }^{18}$.

O argumento de Brown é extremamente importante porque sinaliza o esforço de diferentes estudiosos em construir o problema dos significados da violência feminina contemporânea a partir de arcabouços teóricos alternativos à psicanálise. Não que a tradição de abordagem psicanalítica seja de todo desprezada, mas passa também a haver a percepção de que este modelo, que orienta grande parte das construções da problemática, mostra-se insuficiente para a interpretação das questões e das

\footnotetext{
15 Brown, Jeffrey A., "Gender, Sexuality and Toughness: The Bad Girls of Action Film and Comic Books", op. cit., 2004, pp. 69-70.

16 Brown, Jeffrey A., op. cit., 2004, p. 52.

17 Cf. Brown, Jeffrey A., op. cit., 2004, p. 68.

18 Brown, Jeffrey A., op. cit., 2004, p. 69.
} 
contradições presentes nestes filmes e, talvez algo que se mostra ainda mais importante para estes autores, impede que os elementos que apontam para uma transformação nas formas de apresentação da violência feminina possam ser devidamente considerados como tal. De acordo com Elizabeth Hills, isto se dá

\begin{abstract}
(...) porque as considerações psicanalíticas que teorizam a diferença sexual relacionando oposições binárias no interior de uma estrutura (homem ativo / mulher passiva) necessariamente colocam a subjetividade feminina normal como passiva ou em termos de uma falta. Desta perspectiva, mulheres agressivas e ativas podem apenas ser vistas, no cinema, como fálicas, artificiais ou como "homens figurados" 19.
\end{abstract}

Para Hills, tais personagens representam um desafio às lógicas binárias, porque mobilizam uma série de emoções, dons e habilidades que tradicionalmente foram definidas como essencialmente masculinas ou femininas, reunidas numa figura feminina cujo corpo passa a ser o lugar do novo, da ação e da invenção. Deste modo,

o potencial transformador destes personagens femininos não pode ser apreciado através de leituras habituais ou arcabouços teóricos convencionais que alegam saber de antemão o que corpos femininos são capazes de fazer ou o que pode ser dito a seu respeito ${ }^{20}$.

Sob a égide da busca de uma mulher verdadeira cuja associação com a violência põe em xeque sua "feminilidade" ou de uma nova mulher cuja mesma associação cria uma "subjetividade mais completa" em termos de ação e atividade ${ }^{21}$, as contradições e tensões que contribuem para a caracterização de personagens como Lara correm o risco de ser apagadas. Não se trata aqui, portanto, de tomar um partido em uma ou outra direção, mas sim de remontar o percurso que permite que Lara apresente-se como heroína, considerando as contradições e ambiguidades que a aproximam da figura da dominatrix. Se de fato há um espectro de dominatrix em personagens femininos contemporâneos, os dois filmes da série Tomb Raider mostram que mais do que dar uma "feição" a estes personagens, os elementos que propõem que Lara apareça, em alguns

19 Hills, Elizabeth, "From 'figurative males' to action heroines: further thoughts on active women in cinema”, op. cit., 1999, p. 39.

20 Hills, Elizabeth, op. cit., 1999, p. 39. 
momentos, como uma dominatrix, são justamente os elementos que "ameaçam" a emergência de uma nova subjetividade feminina na tela. Assim, é por meio destas contradições e ambiguidades que a disputa discursiva acerca das imagens femininas no cinema contemporâneo pode ser acessada, tornando possível vislumbrar quais permanências e quais transformações fazem parte desta configuração. Tem-se em mente que, dependendo de certas estratégias narrativas e estéticas, pode-se tanto reforçar o imaginário em que estes personagens aparecem como homens figurados, ou como mulheres fálicas, quanto restabelecer as distinções do sexo que colaboram na construção de uma nova subjetividade feminina. Tais estratégias por vezes mostram-se através de detalhes, como na sequência que mostra Lara dirigindo-se à casa de leilões. A figura que aparece completamente coberta pela roupa de motociclista e pelo capacete pretos, saindo em disparada da Mansão Croft, em tomadas que propositalmente escondem os contornos de seu corpo que poderiam denunciar seu sexo, reinscreve-o quando Lara aparece com a jaqueta aberta, mostrando, através da camiseta curta, parte de sua cintura. Não por acaso, é na mesma casa de leilões que Lara encontra Alex West pela primeira vez na narrativa. A maneira como o antigo relacionamento dos dois é introduzido na narrativa serve tanto a um reforço de sentido de que a figura que se vê ali é mesmo uma mulher (heterossexual), apesar de por vezes sua aparência não permitir de pronto que seja reconhecida imediatamente como tal, quanto de propor um personagem independente e decidido, cuja desilusão amorosa ancora-se sobre um conflito de valores e não sobre o sofrimento ou a perda de uma variedade de sentimentos. A proposição de que a subjetividade de Lara é de um tipo diferente daquela tradicionalmente concebida como feminina perpassa, desta maneira, um tensionamento constante com os signos que poderiam ameaçar sua imediata identificação como tal. A relevância de seu personagem está, então, exatamente vinculada a esta combinação entre sexo, poder e violência que se mostra capaz de construir um personagem indubitavelmente feminino.

\section{AS ORIGENS DE LARA Croft}

A estrutura da narrativa de Lara Croft: Tomb Raider é linear, sendo que grande parte da trama se passa durante os oito dias em que ocorre o alinhamento dos planetas que serve de motor à história. No que se refere à consecução dos dias no interior da

${ }^{21}$ Cf. Hills, Elizabeth, op. cit., 1999, p. 39. 
narrativa, duas principais estratégias são utilizadas. Na primeira delas, espaço e tempo ancoram-se mutuamente. Assim, são apresentados planos externos da casa no início e ao fim de um novo dia. A outra estratégia passa pela fala dos personagens. $\mathrm{O}$ início da história é remetido a um dia 15 de maio tanto por Lara, que lamenta o desaparecimento do pai, quanto pelo líder dos Illuminati em Veneza, preocupado com o tempo que resta até o fim do alinhamento dos planetas. Eles também informam que o fim do alinhamento ocorrerá em uma semana a partir do dia em que a história começa. Além disso, outros personagens contam as horas que faltam para estágios específicos do fenômeno. Como o filme termina na Mansão Croft após o seu ápice, pode-se supor que a história se passe entre oito e nove dias.

A montagem se utiliza primordialmente de planos de curta e média duração, impondo um ritmo mais intenso à narrativa nas cenas de combate e de deciframento dos sinais que levam às metades do triângulo. A montagem sonora ancora-se em grande medida na utilização de estilos musicais variados, que servem aos momentos de tensão e distensão da ação exibida na tela. Destacam-se entre os elementos da montagem sonora as músicas eletrônicas, que aparecem geralmente associadas às situações de combate. Parte da trilha sonora musical aparece também integrada à ação, como quando Lara toca música no robô e quando salta pelo hall da casa, ainda que nestas sequências ela não seja inserida como som direto.

A narrativa de Lara Croft: Tomb Raider pode ser dividida em três grandes partes de durações desiguais. Na primeira parte, além da caracterização inicial de Lara através do treinamento com o robô, são introduzidos na narrativa os aliados de Lara - Bryce e Hillary -, Alex West - seu antigo namorado -, e o desafio a ser superado por ela.

Bryce e Hillary são funcionários de Lara na Mansão Croft, uma ampla propriedade situada numa área pacata e isolada, que abriga um palácio, um bosque ${ }^{22} \mathrm{e}$ um jardim arborizado. Seu aparecimento, na primeira parte da narrativa, colabora na construção das origens familiares de Lara e da especificidade de sua inserção social. A Mansão Croft é composta tanto por ambientes que remetem às atividades domésticas, quanto por ambientes que remetem às atividades de Lara, marcando as particularidades de seu estilo de vida. Deste modo, ao ser vista sair por uma porta de vidro arrastando o robô que simulara o combate no "templo egípcio", Lara aparece no interior da residência, num ambiente repleto de monitores de computadores e outros equipamentos,

22 Visível apenas em Lara Croft Tomb Raider: A Origem da Vida, quando Lara pratica tira ao alvo cavalgando. 
onde Bryce aparece pela primeira vez com um joystick nas mãos. As paredes de vidro transparente desta sala, através das quais podem ser vistos uma majestosa escada iluminada por uma imensa janela e um grande lustre no teto, inserem este ambiente no seio da residência, reforçando que a faceta da vida pública da senhora da Mansão Croft não é aquela dos salões de gala ${ }^{23}$.

Hillary aparece logo depois de Lara entregar o robô a Bryce. A aparência casual de Bryce, que veste uma calça jeans clara, camiseta ocre e jaqueta preta, contrapõe-se à do mordomo, que veste um traje formal, composto pela calça, colete e casaco inglês pretos, camisa branca listrada de cinza claro e gravata cinza escuro. Hillary, que trouxera a Lara uma garrafa de água e uma toalha, segue-a pelo corredor em direção ao seu aposento, onde a protagonista toma banho em seguida. O interior da parte propriamente residencial do palácio é vista, então, através de alguns planos do hall de entrada e do corredor do primeiro andar. Assim, o espaço da residência apresenta-se como um ambiente em que se misturam aparatos tecnológicos contemporâneos à arquitetura inglesa da era jacobina ${ }^{24}$. O hibridismo entre contemporaneidade e passado se realiza através da figura de Lara, sendo que Bryce e Hillary se relacionam mais diretamente com um e outro aspecto da caracterização do personagem. Desta maneira, Bryce é o personagem que se encarrega de tudo o que concerne à parafernália tecnológica utilizada por Lara em suas atividades. Já Hillary, ao encarregar-se da Mansão Croft e dos assuntos pessoais de Lady Lara, é o personagem que explicita o vínculo da protagonista com as origens aristocráticas de sua família.

Tradicionalmente, segundo Norbert Elias, o tamanho e o esplendor da casa de um membro da corte

não constituem uma expressão primordial de riqueza, mas sim uma

23 Cf. Elias, Norbert. A sociedade de corte: investigação sobre a sociologia da realeza e da aristocracia de corte. Rio de Janeiro: Jorge Zahar Ed., 2001, p. 75.

24 A era jacobina inglesa refere-se ao reinado de James I (1603-1625). De acordo com Caroline Elam, elementos decorativos renascentistas começaram a ser incorporados na arquitetura inglesa no reinado de Henrique VIII (1509-1547), passando a ser utilizados em larga-escala durante o reinado de Elizabeth I (1558-1603). Neste período, os motivos de origem francesa, italiana e flamenga eram mesclados indiscriminadamente, retirados geralmente de livros de arquitetura. A era jacobina unificou a diversidade de elementos presentes no período anterior, estabelecendo um estilo mais coeso. A arquitetura do período foi fortemente marcada pela presença de artesãos de origem alemã e flamenga no reino, que utilizavam, nas fachadas dos edifícios, tijolos com adornos de pedra e pequenas torres com cumeeiras flamengas. Cf. Elam, Caroline [et. al.]. "The low countries and Britain". In: Fletcher, Sir Banister; Cruickshank, Dan (ed.) A History of Architecture. Oxford: Architectural Press, 1996, p. 1010. Este tipo de arquitetura faz-se visível principalmente através das tomadas externas à Hatfield House, palácio construído em Hertfordshire, entre 1607 e 1611, e que serviu de locação nos dois 
expressão primordial da posição e do nível. Para o grand seigneur, a aparência física da casa no espaço é um símbolo da posição, importância, do nível de sua "casa" no tempo, ou seja, de sua estirpe no decorrer das gerações, com isso simbolizando também a posição e a importância que ele mesmo possui como representante vivo da casa ${ }^{25}$.

No caso de Lara, a casa marca tanto sua riqueza, quanto sua posição social. Contudo, Lara se apresenta como uma Lady que recusa os padrões de etiqueta ${ }^{26}$ e feminilidade que marcam sua posição. Tal proposição aparece pela atitude do personagem em não usar o vestido e o chapéu brancos que Hillary lhe oferece após o banho. Ao passar por ele em direção ao closet, o mordomo lhe explica que só estava tentando transformá-la numa Lady. Como resposta, Lara tira a toalha que a cobria, mostrando as costas nuas e as curvas de seus seios, numa atitude provocante. Hillary lhe diz, então, que uma Lady deveria ser discreta ${ }^{27}$, algo com a qual ela ironicamente concorda, mostrando, assim, uma diferenciação entre o que se esperaria que ela fosse e o que ela é. Assim, Lara sabe-se sedutora e exibe-se sem pudor, em trajes que não seriam exatamente tidos como apropriados para uma Lady. A recusa dos padrões de etiqueta reaparece quando Lara vai até a casa de leilões encontrar o Sr. Wilson, antigo amigo de seu pai e um especialista em relógios antigos. Lara entra no salão onde acontece um leilão, vira a cadeira à frente da qual se senta, colocando os pés sobre ela, recostando-se de forma desleixada. O homem que está a seu lado olha para seus pés com uma feição de desaprovação, enquanto Lara encara-o sem constrangimento. $O$ figurino de Lara - composto por camiseta, calça e jaqueta de couro, apropriados para guiar a motocicleta com que vai ao local - distingue-se da indumentária formal utilizada pela maioria dos figurantes - homens em sua maioria - e atores vistos na cena.

A parte inicial apresenta também os adversários de Lara. Em uma reunião em Veneza, o chefe de uma sociedade secreta cobra resultados de Manfred Powell -

filmes da série.

25 Elias, Norbert, A sociedade de corte, op. cit., 2001, p. 75; grifos do autor.

26 De acordo com Elias, a etiqueta tem grande função simbólica na estrutura de uma sociedade de corte tradicional, pois "cada atitude revela um sinal de prestígio, simbolizando a divisão de poder". Elias, Norbert, op. cit., 2001, p. 102.

27 Modest - o termo utilizado no diálogo - significa modesta, casta, tímida, discreta (no sentido de vestir-se e comportar-se adequadamente). O último significado do verbete parece, dessa forma, mais apropriado que o utilizado na legendagem, modesta. Cf. "modest". In: Merriam-Webster Online Dictionary, disponível via URL em: http://www.merriam-webster.com/dictionary/modest; acessado em 13/03/2010. 
devidamente acompanhado por seu assistente, o sr. Pimms ${ }^{28}$ - fornecendo as primeiras informações a respeito da disputa que envolverá os personagens. A primeira parte se encerra estabelecendo o vínculo entre Lara e o desafio: no dia do aniversário do desaparecimento de seu pai, um raríssimo alinhamento de planetas se inicia. Lara sonha com o pai e descobre um relógio num aposento escondido debaixo de uma das escadarias da casa.

Como acontece em Sedução e Vingança, a linearidade do tempo é relativamente preservada durante o sonho de Lara pela inserção de planos do personagem agitando-se na cama, intercalados às imagens do sonho propriamente ditas. Através de fade in $(s)$ sucessivos, mostra-se o personagem entrar na tenda de seu pai armada no jardim da Mansão Croft. Se no início da sequência tem-se a impressão de que se trata do monumento construído em sua memória, vê-se Lara entrar numa tenda de pano ao invés de adentrar pelas paredes de pedra do memorial. Ela, então, transforma-se na menina que escuta as histórias de seu pai. Durante o sonho, reforça-se o vínculo de Lara com ele, já que a menina relata que, por ter perdido sua mãe muito cedo, não se lembra dela. O pai fala também sobre um triângulo dotado de poderes extraordinários e que é ativado por um alinhamento de planetas que acontece uma vez a cada cinco mil anos. Planos do espaço no início do alinhamento e da imagem de um baú irradiando luz através das frestas de sua tampa também são inseridos no sonho. Lara acorda assustada, apanhando por reflexo o punhal que esconde debaixo do travesseiro, como se sentisse ameaçada.

O relógio encontrado por Lara oculta, no entanto, um outro mecanismo: um objeto redondo de metal, parecido a um relógio repleto de inscrições e desenhos, em cujo centro vê-se um triângulo e o que ela identifica como o Olho Que Tudo Vê. O mecanismo é idêntico ao símbolo visto durante a reunião da qual Powell participara em Veneza, o que estabelece uma primeira conexão entre os personagens da trama ${ }^{29}$. Investigando o significado do mecanismo, Lara procura, então, o Sr. Wilson na busca de informações que a ajudassem a descobrir seus mistérios: ao abrir a tampa do mecanismo, vê-se o olho cor de âmbar brilhar no centro de uma circunferência azul, também brilhante. Sobre a circunferência, um dos ponteiros começara a mover-se na noite em que Lara o encontrara, de trás para frente, como se estivesse em contagem regressiva. De acordo com ela, com o passar do tempo, as luzes do estranho relógio

28 O Sr. Pimms aparece como o espelho invertido de Hillary, destacando a posição social de Powell.

29 É curioso que Lara não estabeleça um vínculo imediato entre o relógio e os Illuminati, uma vez que, no encontro que tem com Powell em Veneza, será a partir deste mesmo símbolo que Lara afirmará que 
brilham mais intensamente. As reentrâncias na parte de trás do mecanismo sugerem-na que o objeto seja uma chave - uma informação que estabelece, então, uma segunda conexão entre os personagens de Lara e Powell, já que é uma chave o objeto que ele procura. O Sr. Wilson mostra-se nervoso com a descoberta do artefato, mas nega conhecê-lo, mentindo para ela. Mais tarde, ele lhe recomendará que procure Powell, dizendo-lhe que o adversário é um outro especialista em relógios antigos.

Na casa de leilões, Lara encontra também um antigo namorado. Alex West, outro saqueador de sítios arqueológicos, é introduzido à trama como um personagem ambicioso, que busca objetos antigos e mitológicos por dinheiro. Assim, ele se contrapõe a Lara, que explora sítios arqueológicos pelo sabor da aventura. Neste encontro, revela-se que a tensão entre os dois teria surgido quando West se apossa de um objeto que ela considerava seu. West, no entanto, confronta-a, dizendo que os dois são saqueadores e que não há diferença entre a apropriação de um artefato cultural para si ou para vender no mercado de antiguidades ${ }^{30}$. Durante o reencontro, West tenta uma reaproximação com Lara, que o rechaça. Como saqueadores de tumbas, a rivalidade entre os dois permanece até o fim da narrativa. $\mathrm{O}$ argumento de West não deixa de ser válido, mas a possível caracterização de Lara como uma possível anti-heroína - não apenas por ser também uma saqueadora de tumbas, mas por comportar-se de maneira diferente da que se espera de um membro da nobreza britânica - perde força durante o desenvolvimento da narrativa, especialmente após ela tomar a missão do pai para si.

Depois do telefonema do Sr. Wilson, Lara encontra Powell em um amplo salão de sua casa, onde acontece uma recepção. Ao ser levada ao local do encontro por Pimms, Lara surpreende-se com a festa, e a ausência de outras peças que poderiam corroborar a informação de que Powell é um especialista em relógios. Desconfiada, ela

Powell é um membro da seita.

30 Os dois personagens contrapõem-se também ao protagonista da série Indiana Jones. Apesar de Lara Croft ser frequentemente citada como a versão feminina de Jones, há diferenças bastante pronunciadas entre os dois personagens. Ao contrário de Lara, Indiana Jones é um cético. Professor de arqueologia, ele inicialmente não crê nas dimensões fantásticas associadas aos objetos que procura em suas aventuras. Os aspectos "científicos" e "acadêmicos" da caracterização do personagem fazem com que ser surpreendido e convencido da existência destas dimensões seja um componente dos desafios enfrentados por ele em cada uma das quatro narrativas em que aparece, algo que nem Lara nem West com ele compartilham. Indiana Jones tem como principal motivação para a busca de objetos antigos e mitológicos a crença de que deveriam pertencer a museus e, para ele, não há qualquer contradição na venda de tais artefatos para estas instituições. Qualquer outra motivação para a apropriação destes artefatos aparece, então, desvalorizada e ilegítima. Assim, o fato de ele ser arqueólogo aparece como fonte de legitimação de suas ações, que o personagem faz questão de distinguir de roubo. Apesar disso, a prática da arqueologia parece ser incompreendida, nestas narrativas, justamente por ser confundida como tal. Se no caso de Jones há uma identificação completa do personagem com a arqueologia tal qual construída nestas narrativas, Lara faz pouco caso quando Powell a elogia por ser 
pergunta ao assistente qual é a ocupação de seu chefe. Pimms conta que Powell é advogado e ele os interrompe, perguntando retoricamente se isso não era óbvio, para então apresentar-se como conselheiro real. Os dois sentam-se frente a frente em divãs dispostos no meio do amplo salão e Powell menciona que encontrara seu pai uma vez, em Veneza, e que lamentou saber de sua morte. O diálogo sugere ao espectador que o pai de Lara poderia ter alguma relação com a sociedade secreta da qual Powell faz parte, o que será confirmado por ele mais tarde. Diferente da reação que Lara mostrara na presença do Sr. Wilson, quando ele mencionara seu pai, os comentários de Powell não lhe despertam comoção, mas sim irritação. Lara mostra-lhe, então, a foto do misterioso relógio. Seu adversário também nega conhecer sua origem. Dessa vez Lara percebe que seu interlocutor está mentindo. O personagem tem suas suspeitas confirmadas quando, na noite após o encontro com ele, sua casa é invadida por vários homens fortemente armados, que lhe roubam o mecanismo.

Após dizer a Hillary que não precisaria mais de seus serviços, de pijama, Lara faz acrobacias aéreas ${ }^{31}$ no hall da casa. A sequência, que é acompanhada por música clássica, compõe uma atmosfera de tranquilidade e relaxamento. A montagem paralela mostra Bryce escutando música eletrônica em seu trailer estacionado no jardim e os homens de Powell, vestidos de negro, aproximando-se da casa, em meio à intensa chuva que cai. Eles bloqueiam a porta do trailer de Bryce, sem que ele se dê conta de que há algo de errado. Lara continua saltando pelo ar, quando a porta de vidro da sala onde está o mecanismo é acionada pelo sistema de segurança, que a fecha automaticamente. Lara vê o alerta do sistema de segurança e põe-se de prontidão em cima do lustre do hall. A música clássica que acompanha os movimentos de Lara pelo ar cessa pouco antes de se escutar o estrondo causado pela quebra dos vidros da clarabóia, por onde entram os invasores. Parte dos homens de Powell permanece na entrada da frente da casa. Um forte tiroteio se inicia ao som da música eletrônica que acompanhará a sequência até o final. Desarmada, Lara imediatamente lança-se pelo ar em direção ao corredor do primeiro andar, onde luta com vários homens. Bryce, que se dá conta da invasão, mas não consegue sair do trailer, volta ao computador tentando fazer Simon funcionar, sem sucesso. Em seu quarto, Hillary se prepara para o combate, compondo-se sem pressa. Enquanto isso, Lara volta a saltar pelo ar, conseguindo alcançar seu punhal sobre um cintura de Lara. Em um dos making-off( $s$ ) incluso no DVD do filme, Angelina Jolie e Simon West 
móvel da sala. Com ele, corta a corda de dois invasores e esmurra um terceiro, que fica dependurado, desmaiado. Lara, então, se segura no teto da casa, esperando por mais intrusos. Soltando-se do teto, ela alcança o chão rapidamente, agarra um deles e o arremessa na direção dos outros, derrubando-os. Correndo pelo lado de fora do parapeito do primeiro andar, Lara foge dos tiros do invasor que, ainda pendurado, recuperara os sentidos, enquanto dá voltas com sua corda na corda dele, aproximandose cada vez mais. Quando consegue alcançá-lo, corta as cordas que os seguram, caindo no chão. Hillary finalmente deixa seu quarto, armado com um rifle, quando se veem os homens de Powell tentando quebrar a porta de vidro a tiros. Lara escapa para a sala de equipamentos pelo elevador de serviços, com o intuito de pegar suas armas.

É lá que a segunda parte da luta ocorre. Impedida de pegar as armas pela chegada de alguns homens que a perseguem, Lara protege-se atrás de uma mesa. Enquanto isso, os invasores estouram a porta de vidro com explosivos, acionando uma grade de ferro que encerra novamente o mecanismo na sala. Bryce, que acompanha a invasão pelas imagens do sistema de segurança, vê os homens de Powell tentando abrir um buraco na grade de ferro com um maçarico. Hillary tenta, com o rifle, impedi-los. Bryce consegue falar com Lara por um comunicador e a auxilia, informando quantos são e onde estão os homens de Powell na sala de equipamentos. Lara adapta ferramentas, improvisando uma pistola, com a qual acerta dois deles. Um terceiro atira em sua direção, fazendo com que as chaves de seus veículos caiam perto de si. Lara o distrai, destravando os carros, e o nocauteia com um chute. Outros homens aparecem, mas ela consegue alcançar a moto usando um carrinho para mecânico como skate. No caminho em direção à moto, ela rouba uma metralhadora de um dos invasores e contraataca, conseguindo alcançar a escada que a leva de volta ao hall. Apesar do combate entre Lara e os homens de Powell ser construído de forma a mostrar toda sua habilidade, boa parte do aposento é destruída e ela não consegue impedir que o objeto seja roubado.

Esta parte da narrativa tem Londres como recorte espacial primordial. É nesta cidade onde se situa a casa de leilões visitada por Lara e a casa de Powell. A Mansão Croft parece situar-se nos arredores da cidade ${ }^{32}$. A arquitetura dos edifícios mostrados pela narrativa remete a diferentes períodos históricos. No interior dos edifícios, objetos

chamam-nas de bungee-ballet.

32 Em Lara Croft Tomb Raider: A Origem da Vida, um intertítulo anuncia que a mansão localiza-se no condado de Buckinghamshire, cuja sede, Aylesbury, situa-se a cerca de setenta quilômetros de 
antigos oriundos de diversas culturas e outras obras de arte podem ser vistos com frequência. O único ambiente que traz marcas contemporâneas é a Mansão Croft. Ao percorrer a cidade, no entanto, Lara deixa ver um panorama mais heterogêneo, com prédios e pontes de arquitetura mais recente. Nesta parte da narrativa introduz-se também Veneza como recorte espacial secundário. A cidade é vista através de um plano alto e de planos que mostram o interior da igreja onde o conselho dos Illuminati se reúne. É também em Veneza que Lara, mais tarde, visita Alex West em seu quarto de hotel.

As duas partes seguintes da narrativa relatam a cruzada ${ }^{33}$ de Lara em busca do mecanismo e das metades do triângulo às quais ele dá acesso, objetos relacionados ao cumprimento de uma antiga profecia. O desafio aparece, a partir da segunda parte da narrativa, não apenas como forma de recuperar o que lhe fora roubado, mas como uma herança paterna. Através de uma carta, escrita por seu pai antes de seu desaparecimento, Lara é informada sobre o que deve fazer: destruir as metades do Triângulo da Luz, evitando, assim, que a profecia sobre o poder de controlar o tempo seja cumprida pela seita dos Illuminati, a sociedade secreta mostrada na primeira parte da narrativa. No início da sequência, enquanto Lara lê a carta que seu pai escondera na contracapa de um livro de William Blake na biblioteca da casa, escuta-se a voz em off de Lord Croft. O pai de Lara reaparece, então, através de um fade in, narrando o conteúdo da carta ora como se a estivesse escrevendo, ora como se conversasse com ela. A fala de Lord Croft é didática, fornecendo todos os detalhes do desafio, cujo sentido, até este momento da narrativa, ainda não estava plenamente justificado. O tempo da sequência avança ainda mais em direção ao passado, quando Lord Croft fala sobre o povo que cunhara o Triângulo da Luz e sobre o desejo dos Illuminati em apropriar-se de seus poderes. As imagens, neste sentido, dão forma à proposição do passado mitológico sobre o qual se refere o personagem.

Assim, a segunda parte da narrativa leva Lara ao Camboja, onde reencontra West

Londres.

33 A camiseta que Lara usa ao preparar-se para deixar a Mansão Croft rumo ao Camboja, onde se vê uma cruz vermelha estampar a camiseta branca propõe, dessa maneira, que a aventura de Lara constitui-se como uma cruzada. De acordo com José Roberto Mello, ainda que o fenômeno das cruzadas medievais sejam mais associadas às expedições à Terra Santa, as expedições dirigiram-se também a outras direções, num movimento que visava a conquista de territórios, a cristianização de pagãos e o combate aos cristãos heréticos. Cf. Mello, José Roberto. As cruzadas. São Paulo: Ática, 1989, p. 5. Neste sentido, o desafio de Lara tem também como pano de fundo um combate à heresia dos Illuminati em apossar-se dos poderes de Deus sobre o tempo - algo que se depreende dos argumentos de Powell no encontro que tem com Lara em Veneza. 
trabalhando para Powell. Para encontrar as metades do triângulo, faz-se necessário encontrar o local onde a chave se encaixa no interior dos templos. No Camboja, Lara surpreende Powell e seus homens, sugerindo, no último minuto, que o local que eles acreditam ser o correto é apenas um espelho do original. Powell entrega o mecanismo a ela, que consegue se apossar da primeira metade do triângulo. West, entretanto, consegue recuperar a chave para Powell.

Neste recorte espacial, imagens de templos predominam na paisagem, composta também por florestas, cachoeiras, rios e estradas de terra. O Camboja aparece, sobretudo, como um lugar místico, tanto pelo aparecimento da menina que lhe mostra as flores que revelarão a entrada do templo onde a primeira metade do triângulo está escondida quanto pelo chá que lhe é oferecido pelo monge budista, que milagrosamente cura o ferimento de seu braço.

$\mathrm{Na}$ terceira parte da narrativa, Lara e Powell detêm, cada um, uma das partes essenciais para o cumprimento da profecia. Lara, ainda no Camboja, contacta o adversário, que lhe propõe que reavaliem suas posições na disputa. Faltando pouco tempo para a fase final do alinhamento e sem saber a localização do templo que esconde a segunda metade do triângulo, Lara, apesar dos riscos, aceita encontrá-lo em Veneza. Os dois personagens encontram-se, então, na igreja onde se reunira o conselho dos Illuminati. Lara, que percebe que Powell faz parte dos Illuminati, provoca-o enquanto ele tenta convencê-la a associar-se a ele na busca pela outra metade do triângulo. Questionando sua posição no interior da seita ao fazer referência à cadeira que se situa ao centro da fileira disposta à frente das mesas do amplo salão, Lara sugere que Powell não é quem ocupa a posição mais alta na hierarquia dos Illuminati. Desafiadoramente, ela senta-se na cadeira do chefe do conselho. Powell aceita sua provocação, ocupando o lugar à direita, que afirma ser o seu, para então revelar-lhe não só que tal cadeira fora antes ocupada por seu pai, mas, também, que fora ele quem o havia iniciado. Lara desconcerta-se, acusando-o de ser mentiroso. De acordo com ela, o pai teria lhe contado se integrasse a seita dos Illuminati. Para ela, não havia segredos entre eles. Powell revida, dizendo-lhe que o pai não apenas era um homem de muitos segredos, mas que os guardava especialmente dela. Ainda que Lara duvide das informações que Powell the contara, é por meio dele, portanto, que a protagonista começa a desmistificar a figura paterna. Powell prossegue, propondo-lhe que se associem até o cumprimento da profecia, que lhe dará poderes para retribuir a cooperação de Lara, modificando o passado e trazendo seu pai de volta à vida. De acordo com ele, este seria o objetivo final 
da protagonista. A conversa termina com Lara perguntando-lhe se, de posse da primeira metade do triângulo, Powell simplesmente não a mataria. Dando-lhe as costas sem temor quando o adversário argumenta que poderia fazê-lo naquele momento, Lara deixa a igreja.

Assim, Lara e Bryce dirigem-se com o chefe do conselho dos Illuminati, Powell, seu assistente e seus homens para a Sibéria. Este recorte espacial é construído pela contraposição entre planícies formadas por água e terra congelada e as montanhas em que se situa o esconderijo da segunda metade do triângulo. A Sibéria se apresenta, dessa maneira, como um lugar desolado, uma zona morta não apenas porque os aparelhos eletrônicos deixam de funcionar, mas porque a ocupação humana aparece completamente submetida à natureza - seus habitantes vivem em tendas sobre o gelo sem nenhuma infra-estrutura aparente.

No vilarejo por onde passam em direção ao templo, Lara novamente encontra-se com uma menina que, ao invés de apontar-lhe a direção que deveria seguir, adverte-a de que sua vontade de reencontrar o pai estaria colocando o cumprimento de sua missão em risco. O aparecimento da menina sugere, neste sentido, que Powell acertara em tentar Lara com a possibilidade de ter uma segunda chance com Lord Croft. O diálogo que Lara tem com a menina mostra um lado mais humano do personagem, que problematiza uma identificação imediata entre heroísmo, desprendimento e altruísmo, impondo-lhe também o desafio de superar a perda do pai de modo que a missão que ele lhe incumbira seja levada a termo.

O templo da Sibéria guarda um grande modelo do sistema solar, que é ativado com o início do eclipse que resulta do alinhamento dos planetas. Ali, Lara decifra os sinais que conduzirão à realização da profecia, conseguindo encontrar, mais uma vez, o local onde a chave se encaixa no modelo e pegar a segunda metade do triângulo de dentro da esfera que simboliza o sol. De posse das duas metades do triângulo, o chefe dos Illuminati começa o que crê ser a cerimônia de união das partes do triângulo. Powell interrompe seu discurso, ordenando aos seus homens que o matem. Finalmente de posse das duas metades, Powell tenta juntá-las, mas, para sua decepção, nada acontece.

O personagem, que suspeita do envolvimento entre Lara e West, usa o exnamorado da protagonista para atingi-la, matando-o para forçá-la a mostrar-lhe como reunir as metades do triângulo. Ao ser atingido no peito pelo punhal de Powell, West cai no fosso que margeia o modelo no templo. Lara pula na água para socorrê-lo, mas West 
prende-se nas engrenagens e não resiste. Submersa, Lara despede-se dele com um beijo. De volta à superfície, Powell oferece-lhe trazer West e seu pai de volta caso ela lhe mostre como reunir as partes do triângulo. Ela, tomada pela raiva, cede, mas disputa com ele o poder sobre o tempo.

A disputa entre Powell e Lara pelo triângulo lança-os no espaço mitológico que emerge da união de suas metades. Na sequência, Lara alcança o triângulo no ar em câmera lenta, antes de Powell. A maneira como Lara salta no ar, com um braço estendido em direção ao objeto e a face voltada para cima, iluminada por feixes de luz que vêm desde baixo, dando a impressão de impulsioná-la, lembra muito o modo de voar do Super-Homem. Neste breve momento, Lara aparece, então, identificada ao universo dos super-heróis, construído primeiramente pelos quadrinhos e, mais tarde, pelo próprio cinema. Na imediatez de tal identificação, não apenas se explicita o caráter extraordinário de seus feitos, mas também se apresenta uma base para sua legitimação.

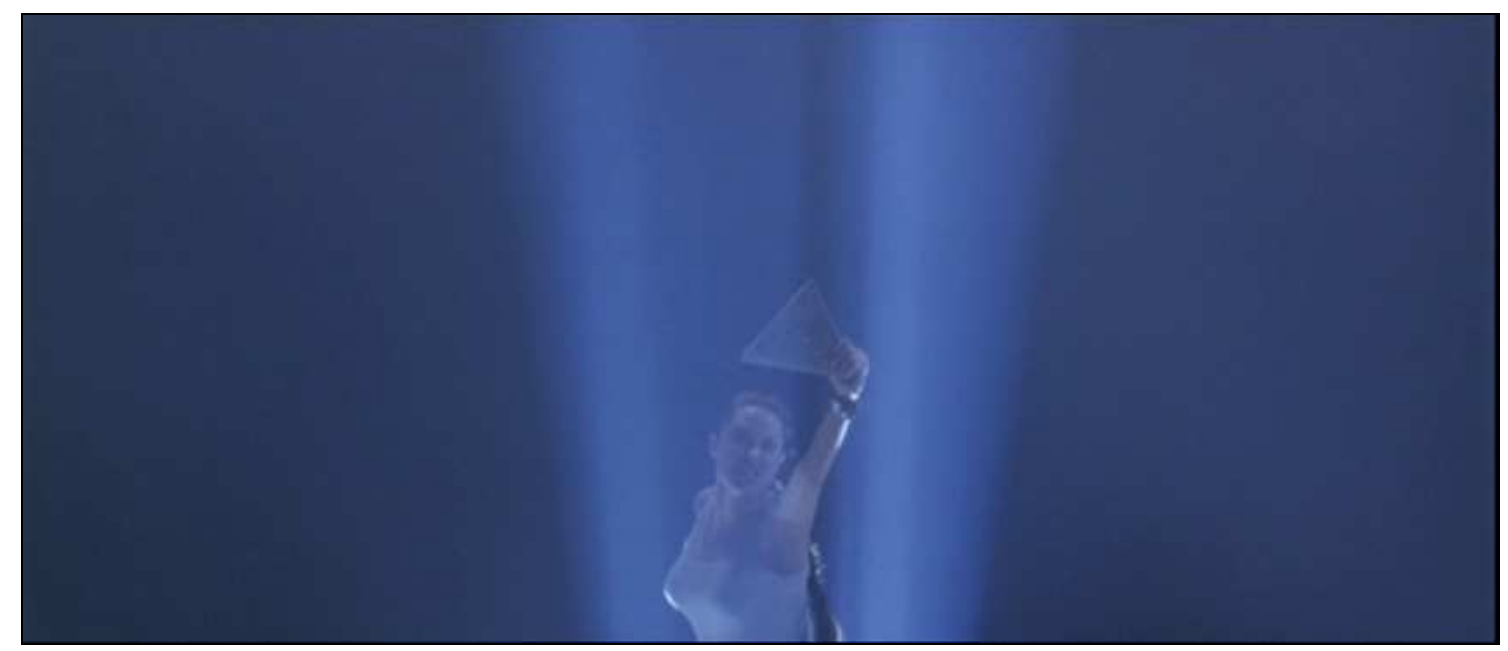

Por um lado, então, sua figura habilita-se a integrar um rol de heróis de características bastante específicas. Voltando seu interesse para a figura de super-heróis como o Super-Homem, Umberto Eco afirma que,

o herói dotado de poderes superiores aos do homem comum é uma constante da imaginação popular, de Hércules a Segfried, de Roldão a Pantagruel e até a Peter Pan. Frequentemente, a virtude do herói se humaniza, e seus poderes, ao invés de sobrenaturais, são a alta realização de um poder natural - a astúcia, a velocidade, a habilidade bélica, e mesmo a inteligência silogisticizante e o puro espírito de observação, como acontece com 
Sherlock Holmes ${ }^{34}$.

Astúcia, velocidade, habilidades de combate, capacidade dedutiva e observacional são atributos que facilmente podem ser reconhecidos em Lara nas duas narrativas em que o personagem aparece. Assim como acontece com os heróis mencionados por Eco, no caso de Lara tais "poderes" também se apresentam como “naturais". É possível compreender, a partir destas considerações, porque, para autores como Hills, o estatuto de heroína é alcançado plenamente apenas quando estas - e outras - qualidades são atribuídas a personagens como Lara. De modo geral, estes são os atributos tradicionalmente considerados como masculinos, porque, num nível fundamental, é da manifestação destas qualidades que emergem imagens do heroísmo. A nova subjetividade feminina - heróica, neste caso em particular - advém, portanto, da inclusão destes atributos à caracterização do personagem.

Por outro lado, inscrevê-la no mundo dos super-heróis apazigua os elementos "perturbadores" de sua caracterização heróica, advindos de sua exacerbada sensualidade, situando-a num esquema mais amplo, conhecido e reconhecível, que não apenas satisfaz uma necessidade de reiteração de um esquema narrativo de base ${ }^{35}$, como dá vazão a fantasias de empoderamento. Neste sentido, Eco continua,

(..) numa sociedade particularmente nivelada, onde as perturbações psicológicas, as frustrações, os complexos de inferioridade estão na ordem do dia; numa sociedade industrial onde o homem se torna número no âmbito de uma organização que decide por ele, onde a força individual, se não exercitada na atividade esportiva, permanece humilhada e determina os movimentos mesmos do homem - numa sociedade de tal tipo, o herói positivo deve encarnar, além de todo limite pensável, as exigências de poder que o cidadão comum nutre e não pode satisfazer ${ }^{36}$.

Por mais que seja possível distanciá-la dos demais súditos da coroa britânica, dada sua situação social, Lara Croft já não realiza a síntese entre distanciamento e identificação da mesma maneira que o Super-Homem e os outros super-heróis o faziam. Lara, assim, aproxima-se e distancia-se do mundo dos super-heróis: possui muitos de

\footnotetext{
34 Eco, Umberto. Apocalípticos e integrados. São Paulo: Perspectiva, 1971, p. 246; grifos meus.

35 Cf. Eco, Umberto, op. cit., 1971, pp. 264-268.

36 Eco, Umberto, op. cit., 1971, pp. 246-247.
} 
seus atributos, mas não se esconde por detrás de um disfarce - de modo que sua personalidade não aparece cindida; seu campo de ação extrapola os limites e os interesses de sua comunidade local, e mesmo sendo inegavelmente guiada pelo "bem", seus interesses pessoais interferem em suas decisões ${ }^{37}$. É exatamente esta proposição que fica evidente quando Lara apossa-se do Triângulo da Luz ${ }^{38}$.

O poder do triângulo lança-a num giro de câmera para dentro do tempo que a levará a encontrar seu pai, num entrecruzamento entre o presente da protagonista e o passado de Lord Croft. Os dois se reencontram no interior da tenda de Lord Croft. Lara, então, acerta as contas com o pai, perguntando-lhe porque não lhe contara sobre seu envolvimento com os Illuminati. Seu pai lhe diz que, além de ser muito pequena, ele esforçou-se para contar apenas o que poderia inspirá-la e mantê-la segura. Lara tenta convencê-lo a usarem o Triângulo da Luz para recuperarem o tempo que lhes fora roubado. Ele, contudo, não aceita, dizendo que ela também roubara tempo e que deveria devolvê-lo e destruir o triângulo. De acordo com ele, o tempo não pode ser mudado. Ao encarar realmente a morte do pai, Lara diz que, subitamente, se sente muito sozinha. Lord Croft reitera que estará sempre com ela, como sempre esteve. A utilização de fade in(s) marca o início e o fim da sequência, que se utiliza também da câmera lenta, valorizando o toque das mãos de um e outro.

Lara retorna, assim, ao momento em que Powell mata West. Na sequência, há uma mistura de tempos no presente da narrativa: Lara avança em direção a Powell enquanto West retroativamente emerge do lago. Vê-se o punhal que o matara deixar seu peito e parar a meio caminho no ar. Todos os outros personagens permanecem imóveis enquanto Lara muda a direção do punhal com dificuldade - o tempo resiste, a lâmina corta-lhe a carne - já que não é fácil mudar o tempo e, com ele, toda a história. Enquanto isso o triângulo gira, suspenso no ar. A coexistência dessas diferentes temporalidades termina quando Lara atira no triângulo, destruindo-o, e o punhal acerta o peito de Powell, derrubando-o no chão. Lara e West aparecem novamente lado a lado, na mesma posição em que estavam antes de Powell matá-lo.

Frente à derrota de Powell, seus homens o abandonam e todos começam a deixar o templo. Powell, caído, retira o punhal do peito e chama Lara, contando os acontecimentos que antecederam o assassinato de Lord Croft. As imagens refutam,

\footnotetext{
37 Para uma discussão sobre os demais elementos presentes na caracterização dos super-heróis, ver: Eco, Umberto, op. cit, 1971, pp. 271-276.

38 Assim como será a superação de seus interesses pessoais que a consolidará como heroína em Lara
} 
entretanto, a fala de Powell, que provocando a protagonista, afirma que Lord Croft implorara por sua vida como uma criança. Assim, o que se vê é um homem firme, decidido a não submeter-se ao seu assassino. A presença da memória do adversário de Lara neste momento da narrativa destina-se, desta maneira, muito mais a preservar o caráter e a dignidade do pai de Lara frente ao público que para ela mesma. Como uma última provocação, Powell mostra-lhe o relógio de Lord Croft que contém a foto de sua mãe $\mathrm{e}^{39}$. Lara cai na armadilha.

West tenta, sem sucesso, convencê-la a deixar Powell e o relógio do pai para trás. Lara pede-lhe, então, que se encarregue de fazer a todos os demais saírem do templo em segurança, o que demonstra que o conflito com Powell assumira, assim, um caráter pessoal, mais importante do que sua própria segurança. Ao aproximar-se do adversário para recuperar o relógio, Powell levanta-se apontando-lhe uma pistola. Lara é rápida: aponta-lhe duas. Lara não leva vantagem porque tem duas pistolas e Powell só tem uma, mas porque a força das armas foi anulada, de modo que, neste momento, virilidade e feminilidade equiparam-se.
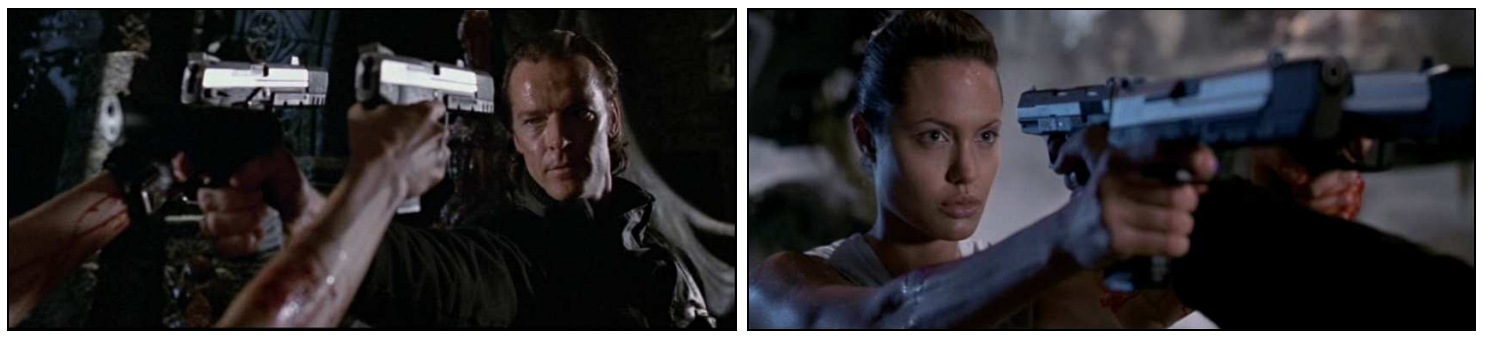

Powell sugere, então, que o duelo prossiga sem armas, provavelmente apostando na superioridade física masculina, e parte para o ataque. Os dois batem e apanham e Lara acaba sendo derrubada no chão. Entretanto, quando Powell acredita que vencera, ela o surpreende, contra-atacando e dando continuidade ao duelo em que, por fim, o nocauteia e recupera o relógio do pai. Com o templo desabando, Lara deixa o adversário para trás sem remorso, entregando-o à morte. A sequência, assim, desmonta qualquer diferença física entre o masculino e o feminino no que concerne a realização da violência, que aparece, então, plenamente justificada em termos de uma "reprovação terminal do mal e no triunfo dos honestos" ${ }^{\prime 4}$. O combate final entre Lara e Powell é

Croft Tomb Raider: A Origem da Vida.

39 Visível também no sonho de Lara com o pai.

40 Eco, Umberto, op. cit., 1971, p. 275. 
construído numa chave bastante conhecida, em que as desvantagens do herói convertem-se em evidência de seu comprometimento, perseverança, força física e de vontade. Como em Rocky (John G. Avildsen, 1976), abater o adversário perpassa um extremo controle de si e certos atributos que se referem ao seu caráter, levando Lara não só a reverter os resultados adversos como a não desistir até vencer, impondo, dessa maneira, sua vontade, que aparece identificada com o justo e correto.

Durante a jornada de Lara em busca das metades do triângulo, o personagem desmistifica a figura paterna, tomando conhecimento através de Powell de detalhes de sua vida e das causas que levaram à morte dele. O filme termina após Lara ser vista de volta à mansão, visitando o memorial erguido em homenagem ao seu pai, trajando o vestido branco e o chapéu que Hillary lhe ofertara no início do filme. Lara se reconcilia, portanto, com suas origens, aceitando a ausência do pai e o seu lugar social. Na última sequência, Hillary e Bryce, surpreendidos com a visão de Lara vestida daquela maneira, acionam o robô, provocando-a. Lara, mais uma vez, aceita a provocação. Em sua última aparição, seu movimento é congelado enquanto ela aponta as duas pistolas em direção ao robô, indicando que uma nova batalha irá começar.

\section{A CONSOLIDAÇÃo de LARA COMO HEROÍnA}

Tendo como desafio impedir que o segredo de Pandora seja revelado e a peste se espalhe pelo mundo, Lara também luta contra o relógio em Lara Croft Tomb Raider: A Origem da $V_{i d a}{ }^{41}$. Cinco partes de durações desiguais compõem a narrativa. A primeira começa a construir o desafio a ser enfrentado por Lara. Após um terremoto atingir a ilha grega de Santorini ${ }^{42}$, caçadores de tesouros arqueológicos dirigem-se para a região. A narrativa se inicia na embarcação de Gus e seus filhos, Nick e Jimmy, que aguardam a chegada de Lara. A protagonista reaparece na parte inicial da narrativa na mesma chave

41 De acordo com o Merriam-Webster Online Dictionary, cradle significa tanto berço quanto lugar de origem. Cf. "cradle". In: Merriam-Webster Online Dictionary, 2010, disponível via URL em: http://www.merriam-webster.com/dictionary/cradle; acessado em 12/04/2010. Ainda que a tradução do título esteja, assim, correta, é interessante preservar a ideia de berço que, em português, também pode ser uma nascente de água. O espaço construído como a Origem da Vida - um lugar subterrâneo, rochoso, profundo, em que se pode andar de ponta cabeça - esconde a Caixa de Pandora. Dentro dela está a peste, a destruição. Conta-se, na narrativa, que ao ver (e libertar) o conteúdo da caixa, Pandora chorou uma piscina de ácido negro. É esta piscina que aparece como o berço da vida no filme. José Carlos Bruni diz que a morte é simbolizada pelas águas sombrias, como as vistas ali. Deste modo, a Origem da Vida é também o berço da morte, onde ela repousa, como um bebê. Cf. Bruni, José Carlos, "A água e a vida", op. cit., 1993, pp. 62-63.

42 Diferente do que acontece em Lara Croft: Tomb Raider, todos os diferentes recortes espaciais 
proposta no primeiro filme da série: exibindo seu corpo e suas habilidades ${ }^{43}$.

Lara chega ao barco e conta aos homens o que acredita ter sido revelado pelo terremoto: o Templo Luna, construído por Alexandre na antiguidade para guardar seus tesouros mais preciosos, o templo teria sido engolido pelo mar, depois de uma erupção vulcânica $^{44}$. Lara crê ter descoberto a localização do templo, após ter analisado as mudanças nas correntes marítimas ocorridas em decorrência do terremoto. Gus, no entanto, mostra-se receoso e contesta os objetivos de Lara, afirmando que talvez o templo que se perdera no tempo não devesse ser descoberto. A protagonista não lhe dá ouvidos, pedindo para não se preocupar. Ela, Nick e Jimmy saem, então, em busca do templo, encontrando-o logo depois.

Nick e Jimmy recolhem jóias e outros artefatos, enquanto Lara explora o local, gravando algumas imagens de painéis que mostram uma caixa ${ }^{45}$ sendo levada em uma carroça. Ao retirar o medalhão incrustado na estátua de Alexandre, uma fonte de luz revela uma esfera dourada presa no teto do templo. O edifício começa a ruir, mas Lara não desiste da esfera. Enquanto ela a retira, cortando o suporte de metal que a sustenta com um maçarico, três homens asiáticos alcançam o templo, assassinando os dois irmãos. No confronto, Lara é ferida na perna por um arpão, perde o medalhão e o orbe. Escapa do templo que desmorona com vida, mas fica à deriva no mar sobre os destroços do barco de Gus por três dias ${ }^{46}$, até ser resgatada por Hillary e Bryce. Toda esta parte da narrativa baseia-se numa combinação de elementos espetaculares e monumentais: a construção do terremoto na Ilha de Santorini, as dimensões do cenário do Templo Luna, a fuga de Lara que primeiro atrai um tubarão, para então golpeá-lo e usá-lo para subir

presentes em Lara Croft Tomb Raider: A Origem da Vida são introduzidos por meio de intertítulos.

43 Lara chega à embarcação de jet ski, espirrando, de propósito, água sobre os dois jovens que a observam, admirando a destreza com que realiza suas manobras com a máquina. Ao subir a bordo, Lara zomba dos dois. Apesar da literalidade do diálogo que afirma que os dois estão molhados, há um conteúdo sexual implícito em sua fala que inverte, assim, provocativamente, como uma brincadeira, os lugares dos dois gêneros.

44 Não deixa de ser interessante como a Ilha de Santorini é construída como o local onde a "civilização" - por meio de seus tesouros antigos e suas instituições contemporâneas (como o casamento interrompido na primeira cena do filme) - está completamente submetida à força das investidas da natureza (terremotos e erupções vulcânicas).

45 No poema de Hesíodo que conta o mito de Pandora, no entanto, a caixa é um jarro. Cf. Hesíodo. "Works and Days". In: Homer and Hesiod. The Project Gutenberg E-book of Hesiod, The Homeric Hyms, and Homerica, p. 26 [linhas 90-105]. Disponível em: http://www.gutenberg.org/catalog/world/ readfile?pageno=26\&fk_files $=1442129$, acessado em 25/07/2010.

46 Lara, neste sentido, apresenta-se como o personagem que resiste à natureza, não se submete à imensidão das águas mediterrânicas, uma caracterização extremamente relevante considerando-se a importância das relações entre natureza e "civilização" propostas a partir da Ilha de Santorini. É possível afirmar que tal caracterização a habilita, neste momento, para desvendar os segredos que os eventos naturais "insistem" em manter fora do alcance dos homens. 
novamente a superfície e, por fim, o submarino com que Bryce e Hillary a resgatam, aparecem nesta chave.

$\mathrm{Na}$ segunda parte da narrativa, que tem como recorte espacial primordial a Mansão Croft, o desafio de Lara no segundo filme da série torna-se evidente. De volta da Grécia, Lara busca obter informações sobre o orbe que encontrara no Templo Luna. $\mathrm{O}$ assassinato de seus associados gregos despertara sua ira, e torna-se explícito que a protagonista procura vingança. É nesta parte que seus adversários serão apresentados: Jonathan Reiss - um cientista ganhador do prêmio Nobel que se tornara negociante de armas biológicas - e os Shay Ling - um grupo de mercenários e contrabandistas chineses comandados pelos irmãos Lo. A maior parte destas informações aparece durante a visita de dois agentes do MI6 à Mansão Croft. Lara, no entanto, é quem correlaciona as informações, percebendo os objetivos de Reiss.

Seu principal adversário aparece nesta parte da narrativa numa reunião em um jatinho, onde assassina um de seus supostos clientes, contaminado-o com o vírus ebola, enquanto o acusa de traição. Reiss oferece aos demais, ao fim da reunião, o antídoto contra o vírus mortal e a arma biológica mais letal do mundo, contra a qual, de acordo com ele, não há remédio algum. Ao chegar ao seu destino, um aeroporto de Hong Kong, Reiss revela sua relação com os Shay Ling ao chefe de sua segurança e confirma que ainda não está de posse do orbe. Assim, a posse da esfera é proposta, na sequência, como via de acesso à arma desejada por Reiss e garantia da realização de seus negócios.

O rol dos principais personagens da trama se completa quando Lara, ao aceitar a tarefa real de tentar recuperar o orbe que lhe fora roubado na Grécia pelos Shay Ling e impedir que Reiss encontre a Origem da Vida - onde estaria escondida a Caixa de Pandora que guarda a arma a que Reiss se referira e que ela vira nos painéis do Templo Luna - exige do MI6 que Terry Sheridan, um desertor da marinha britânica que se tornara mercenário, a acompanhe na sua busca pelos irmãos Lo. Lara negocia com os agentes o perdão pela traição de Sheridan, uma quantia em dinheiro e uma nova identidade como pagamento pelos serviços do ex-comandante que, segundo ela, conhece os esconderijos e o modo de agir dos Shay Ling.

A terceira parte da narrativa mostra o encontro de Lara com Sheridan numa prisão do Cazaquistão e a viagem dos dois pelo interior da China, onde os personagens encontram Chen Lo. O chefe dos Shay Ling aparece, nesta parte da narrativa, negociando o orbe com Reiss, que acaba lhe oferecendo um bônus em dinheiro caso Lo consiga matar Lara. A protagonista, em contrapartida, também tenta negociar a peça 
com Lo. Lara argumenta que ambos perderam homens e que, por isso, não há motivos para mais perdas em nenhum dos dois lados. Lo pede-lhe o dobro da quantia oferecida por Reiss, reafirmando o valor da peça. Lara diz-lhe que Reiss o matará caso lhe entregue a peça, sugerindo que seu adversário não realizaria o pagamento esperado por Lo. O chinês pergunta a Lara, então, se seu governo garantiria sua segurança. Lara nega, mas afirma-lhe que ela se encarregará pessoalmente dessa questão. Lo a provoca, fazendo novamente menção ao confronto dos dois na Grécia, ao afirmar que para ela devia doer dizer-lhe tal coisa. Lara se irrita e ordena a Lo que aceite a oferta. Uma batalha espetacular em meio aos guerreiros de terracota segue-se à tentativa frustrada de negociação com o chinês, que se irrita com a atitude de Lara em dar-lhe ordens. O final do confronto entre Lara e Lo coloca os dois representantes da disputa imperialista por Hong Kong ${ }^{47}$ frente a frente: tentando escapar de Lo, Lara encontra um fuzil com uma baioneta acoplada. Lo a alcança, carregando as duas espadas que retirara de um dos guerreiros de terracota. Sem munição, Lara prepara-se para o duelo final, movimentando o fuzil como um soldado, enquanto ouve-se uma marcha militar. Lo posiciona-se como um espadachim. Os dois enfrentam-se novamente. Ao perfurar-lhe o pé com a baioneta, Lara regojiza-se: "Isso foi bom!". Lo cai no chão e é rendido por Lara, que afirma: "É uma pena que você esteja do lado errado". O diálogo de Lara mostra que a protagonista respeita Lo como adversário. Propondo que Lo conte-lhe a localização do orbe em troca de sua vida, ele confessa quando e onde a esfera seria entregue a Reiss em Xangai. Lara, então, apossa-se do medalhão que Lo retirara do

47 No início do século XIX, o único porto chinês aberto ao comércio internacional era o de Cantão. Os britânicos, favoráveis à abertura dos portos chineses desde o fim das guerras napoleônicas, tinham sua balança comercial com a China ancorada principalmente sobre a venda de ópio, oriundo da Índia e Indonésia. A proibição do comércio de ópio pelo império chinês deflagrou a Primeira Guerra do Ópio (1839-1842), da qual a China saiu derrotada. O Tratado de Nanquim, firmado ao fim da guerra, previu a abertura de outros cincos diferentes portos, o pagamento de indenização pela perda da mercadoria confiscada e destruída pelos chineses, a fixação de impostos comerciais em $5 \%$ e a cessão do território de Hong Kong aos britânicos por cem anos. A pressão pela abertura de outros portos chineses ao mercado de "livre-comércio" internacional prosseguiu durante os anos seguintes. A derrota chinesa na Segunda Guerra do Ópio (1856-1860) e a assinatura de vários tratados desiguais entre o Reino Unido e a China garantiu aos britânicos a hegemonia comercial na região até 1870 , quando outras potências - como a França, a Rússia, a Alemanha e o Japão - passaram a disputar territórios portuários com os britânicos. Com exceção dos quase quatro anos em que Hong Kong foi ocupada pelos japoneses durante a II Guerra Mundial (1941-1945), os britânicos garantiram seu domínio sobre o arquipélago até primeiro de julho de 1997, data em que sua posse foi transferida à República Popular da China. Cf. Fairbank, John King. "Frontier unrest and the opening of China". In: Fairbank, John King; Goldman, Merle. China: a new history. Cambridge, MA: Belknap Press of Harvard University Press, 2006, pp. 187-205, e; BBC News. 1997: Hong Kong handed over to Chinese control. Disponível via URL em: http://news.bbc.co.uk/onthisday/hi/dates/stories/july/1/newsid_2656000/2656973.stm; acessado em $15 / 08 / 2010$. 
Templo Luna e fere-o na perna, revidando o ferimento que sofrera no início da narrativa. De posse da informação que lhe interessa, Lara dá as costas a Lo, que dispara em sua direção. Sem titubear, Lara lança um punhal contra seu peito, o que resulta na morte do adversário.

A quarta parte da narrativa relata a empreitada de Lara e Sheridan para recuperar o orbe. Dois recortes espaciais são construídos nesta parte da narrativa: os arredores do Pagode da Flor em Xangai e Hong Kong. No primeiro deles, apesar dos esforços de Lara e Sheridan em impedir que Xien Lo entregue o orbe a Reiss, este acaba por conseguir apossar-se do objeto, assassinando o segundo irmão Lo em seguida, o que demonstra que Lara estava certa em relação às intenções do adversário. Quando Sheridan já se dera por vencido, contudo, Lara salta de cima do prédio onde estavam observando Reiss em seu helicóptero, conseguindo fixar na caixa que guarda a esfera um pequeno aparelho rastreador, pouco antes de Reiss conseguir movê-la para dentro da aeronave em movimento. É dessa maneira que os dois personagens descobrem para onde a esfera fora levada: Hong Kong, cidade em que o negociante de armas biológicas mantém seu laboratório no interior de um centro comercial.

Reiss reaparece no interior do laboratório, acompanhado pelo chefe de sua segurança, personagem que ganha destaque nesta sequência. Enquanto o escaneamento do orbe está em progresso, Reiss, ao confirmar que Lara sobrevivera à disputa em Xangai, decide que não quer correr riscos, mesmo que o chefe de sua segurança acredite que Lara desconheça a localização do laboratório. Reiss, então, ordena-lhe que leve o material necessário para o desenvolvimento de um antídoto para a peste guardada pela Caixa de Pandora para seu avião. Constrói-se, dessa maneira e a partir da utilização da montagem paralela, um sentido de urgência em relação às ações de Reiss - que pretende escapar com o orbe - e Lara e Sheridan - que buscam recuperá-la.

Enquanto Lara e Sheridan rendem um dos homens de Reiss e conseguem invadir o laboratório, Reiss tenta deixar o local, sendo atrasado por um menino que, ao entrar no elevador do centro comercial acompanhado por sua mãe, aperta os botões de todos os andares. Na sala de monitoramento do laboratório, Lara percebe que o escaneamento dos dados da esfera encontra-se em andamento e decide agir imediatamente. Disparando o alarme de incêndio, a maior parte de seus funcionários começa a deixar o local. Compreendendo que Lara os alcançara ao escutar o som do alarme, o chefe da segurança de Reiss avisa-o da invasão pelo celular. O confronto entre os dois personagens é breve e, apesar das provocações do homem, Lara o golpeia na cabeça de 
modo que ele apenas perca os sentidos. Com o caminho livre, Lara alcança o orbe e, através de um comunicador, contata Hillary e Bryce na Mansão Croft.

Com base nas imagens feitas por Lara, Bryce a informa que decifrara o medalhão, cujas inscrições produzem ondas sonoras, e metade das inscrições da esfera. Lara diz-lhe que enviará as imagens da outra metade do objeto e solicita que ele lhe envie os sons produzidos pelo medalhão e a tradução do conteúdo do orbe assim que complete seu deciframento. Neste momento, Sheridan, que permanecera na sala de monitoramento do laboratório, observa Reiss regressar ao local, acompanhado por vários de seus homens. Lara percebe que não está mais sozinha e tenta impedir que Reiss termine de escanear o conteúdo da esfera atirando em alguns dos monitores dos computadores que processam seus dados ${ }^{48}$. Rendida pelo chefe de segurança de Reiss que recuperara os sentidos, Reiss ordena-lhe que não a mate até que tenham certeza de que o deciframento do orbe fora concluído. Lara pergunta-lhe se de fato acredita que poderá controlar o conteúdo da caixa e surpreende-se ao perceber que Reiss usará seus clientes para exterminar a maior parte da população mundial. De acordo com ele, de posse do vírus letal, ele será capaz de produzir uma vacina com a qual salvará os mais competentes e habilidosos, garantindo, assim, que a vida humana na Terra prossiga.

A interface de um dos monitores do laboratório mostra que o escaneamento dos dados do orbe fora concluído e o processo de tradução iniciado. Reiss, então, ordena que o chefe de sua segurança assassine Lara com um tiro entre os olhos. Para salvá-la Sheridan inicia, neste momento, mais um tiroteio. Em meio dele, Lara consegue recuperar a esfera e suas pistolas e os dois deixam o local. A fuga fora arranjada por Sheridan antes da invasão. Perseguidos pelos homens de Reiss, Sheridan e Lara dirigem-se para o alto da torre do edifício, ainda em construção. De lá, colocam uma veste-planadora e saltam pelos céus da cidade até pousarem, de paraquedas, no convés de um navio ancorado em meio à baía de Hong Kong. Ainda que os dois tenham conseguido recuperar a esfera, Lara desconfia das intenções de Sheridan. Após uma discussão no navio, os dois se separam.

É também nesta parte da narrativa que começa a armarem-se as circunstâncias que forçarão Lara a guiar Reiss em direção à Origem da Vida: Lara perde, no laboratório de Reiss, o comunicador que utilizava para contatar Bryce e Hillary na Mansão Croft. De posse do comunicador, Reiss chegará aos aliados de Lara. Já o orbe,

48 Não deixa de ser curioso como a destruição fílmica de computadores se dê, com frequência, por meio dos monitores, que nenhuma relação têm com o processamento dos dados da máquina. 
que revela ser um mapa do globo terrestre, garante a Lara descobrir, por fim, a localização do esconderijo da Caixa de Pandora. No entanto, sem se dar conta de que Bryce e Hillary encontram-se subjugados por Reiss, Lara a revela a ele, que a segue rumo à África. Sheridan também o faz, descobrindo seu paradeiro ao visitar o barco a partir do qual Lara consegue se comunicar com os outros moradores de sua casa.

A última parte da narrativa constrói os confrontos entre Lara e Reiss e Lara e Sheridan. O recorte espacial construído nesta parte da narrativa é a região africana próxima ao Kilimanjaro, onde Lara encontra Kosa, mais um de seus aliados. Kosa aparece pela primeira vez na narrativa, dirigindo o jipe de Lara nas proximidades de seu vilarejo. Kosa, que recebe uma chamada de Lara pelo celular, não consegue ver onde a protagonista estava, mas o comentário de Lara sobre o automóvel ter sido lavado deixa claro que ela pode vê-lo. Lara reaparece, então, manobrando o paraquedas em direção à parte traseira do jipe, onde pousa sem dificuldade. O diálogo entre Kosa e Lara implica, contudo, num estranhamento por parte dele em relação à maneira como ela age. A partir de Kosa, o elemento espetacular das ações de Lara aparece como o jeito mais difícil de fazer as coisas. Frente à pergunta de Kosa: "Você nunca faz as coisas do jeito fácil?", a resposta de Lara é reveladora, pois projeta em Kosa o lugar de um espectador que espera que faça coisas extraordinárias: "Para desapontá-lo?".

Lara assume a direção do jipe e os dois personagens percorrem a savana africana. Ela reconhece na paisagem a montanha que vira nas imagens criadas pelo orbe. Kosa lhe diz que se trata da Montanha de Deus e sugere que os membros da tribo que a habita possam ajudá-los a encontrar a Caixa de Pandora. A partir de um fade in surge o rosto do chefe da tribo em close-up, estático e com a feição grave, como os demais habitantes da tribo que aparecem em seguida, observando a chegada de Lara e Kosa. Assim como Kosa, o figurino dos membros da tribo é composto por vestes e adornos, embora a cor alaranjada vibrante da indumentária de Kosa sugira que ele integre outra etnia. O tom escuro das vestes dos membros da tribo dá-lhes um caráter sombrio. Diferentes tons de marrom predominam no plano geral que mostra a tribo, fazendo com que seus habitantes pareçam integrados à paisagem, identificando-os com a "natureza" ao seu redor.

Kosa e Lara aproximam-se do grupo em que se situa o chefe, mostrando respeito por meio de uma reverência. Lara retira o orbe de dentro da mochila e os habitantes da tribo mostram seu temor e surpresa frente a sua presença deslocando o tronco para trás. Entretanto, sua reação não se justifica pelo desconhecimento do globo dourado e 
reluzente, mas sim pelo conhecimento do lugar a que ele dá acesso. O chefe é veemente: ordena-lhes que deixem o objeto e partam, sem jamais voltar a mencioná-lo. Kosa, que faz o papel de intérprete continua a mediar o diálogo. O chefe adverte que entrar na Origem da Vida apresenta o risco de espalhar a morte pelo mundo. Lara contraargumenta, dizendo-lhe que homens estão vindo buscar a caixa para usá-la e que ela lamenta incomodar os seus deuses tentando evitar que eles logrem apossar-se dela, mas que fará o que for necessário. O início deste contato com a tribo se dá pela utilização de elementos bastante interessantes. Em primeiro lugar, os membros da tribo "selvagem" não são construídos na chave da ingenuidade. São os guardiões dos segredos que dão acesso à Origem da Vida, os detentores de um conhecimento essencial para a consecução dos objetivos de Lara. A fala de Lara em que menciona seus deuses, de maneira alguma desqualifica as crenças deste povo. Estes "bons selvagens" não aparecem, assim, na chave de uma submissão ao "homem branco", mas como outro, como alteridade. Para que isso aconteça, Lara também deve distinguir-se. Assim, em segundo lugar, estabelece-se também uma distinção entre Lara e os homens que também buscam encontrar a Origem da Vida. Isto se dá por uma identificação imediata entre homens e perigo. Fica claro que a categoria homens que emerge deste diálogo é $o$ homem branco, que aparece aqui identificado à barbárie. É esta diferenciação que garante a Lara o acesso às informações de que precisa.

O chefe retoma, então, o que Gus dissera no início da história sobre haver segredos que não devem ser revelados. Ele tenta assegurar-se que Lara está preparada para carregar o fardo pesado e solitário que encontrar a Caixa de Pandora acarreta. Neste momento, a câmera se aproxima cada vez mais do rosto de Lara. Fixa nela, ela afirma que está pronta para o que virá. A partir daí, o chefe e o sábio da tribo contamlhes sobre o local e os perigos que enfrentarão para alcançar a caixa. Assim, o diálogo entre Lara, Kosa e os membros da tribo anuncia que Lara figura agora como uma heroína responsável e disposta ao sacrifício, como também prepara o espectador para os elementos que se farão presentes no desfecho da trama.

Acompanhados por vários dos integrantes da tribo, encarregados de levá-los até os arredores da Origem da Vida, um deles se destaca. A relação de alteridade entre a mulher branca e os membros da tribo revela, por meio dele, uma inversão do exótico, de modo a que seja Lara que aparece como aquela que fala engraçado. Ela é quem se mostra diferente naquele contexto. Entretanto, a narrativa mostra-se absolutamente incapaz de manter esta relação de alteridade quando os membros da tribo entram em 
contato com $o$ homem branco. A chegada de Reiss e seus homens, de helicóptero, reconstrói a hierarquia entre "civilização" e "barbárie", convertendo-os imediatamente de outro em menos, por meio das diferentes tecnologias de guerra. Lara, que tenta em vão "protegê-los" de modo a evitar o extermínio, assiste o "bom selvagem" tombar. Kosa, como figura intermediária entre um e outro extremos, compreende o perigo e protege-se atrás de uma árvore. Diferente do que ocorrera no ataque à Mansão Croft no primeiro filme, Lara não consegue enfrentar o exército de Reiss.

Rendida facilmente, Reiss tenta dissuadi-la a levá-lo até a Origem da Vida. Na mesma chave em que Powell tentara tentá-la com os poderes do Triângulo da Luz, Reiss "oferece-lhe" a possibilidade de conhecer como a vida se originara ${ }^{49}$. Contudo, desta vez, ao ouvir Reiss perguntar-lhe se não estava tentada, Lara diz-lhe que fora exatamente isso que causara problemas a Pandora. A menção ao personagem mitológico, neste momento, sinaliza a distinção fundamental que será construída no interior da Origem da Vida entre Lara e Pandora, distinção esta que se mostrará essencial à consolidação dela como heroína.

Em face da negativa de Lara em colaborar voluntariamente com ele, Reiss revela que sequestrara Hillary e Bryce. Percebendo que Lara seria forçada a guiar Reiss até a Origem da Vida, Kosa intervém, relembrando-a que o esconderijo da Caixa de Pandora situa-se depois do desfiladeiro, o que implica que o grupo teria de sobreviver ao percurso protegido pelos Guardiões das Sombras para alcançar seu destino, algo que, de acordo com os sábios da tribo, ninguém ainda havia logrado. Lara, portanto, vê no trajeto a possibilidade de livrar-se de seus adversários e concorda em guiar Reiss até a Origem da Vida.

Sheridan reaparece, libertando sem dificuldade Hillary e Bryce dos homens de Reiss. A partir daí, por meio da montagem paralela, mostrar-se-á tanto as ações do excompanheiro de Lara, quanto às do grupo que já iniciara o trajeto em direção à Origem da Vida.

Desde as primeiras imagens do desfiladeiro por onde este grupo caminha, mostrado a partir de cima, os arredores da Origem da Vida aparecem mergulhados na semi-escuridão da noite iluminada pela lua cheia. Tais imagens colaboram na proposição de que o local é composto por uma terra morta, coberta por troncos de

49 Não deixa de ser interessante como as semelhanças fisionômicas entre o homem branco e a mulher branca se exacerbam nesta sequência, quando Reiss aparece com os olhos claros perturbadoramente arregalados. 
árvores enegrecidos e sem vida, um terreno cujos limites são marcados pela presença de primatas de olhos tão receosos quanto assustadores. Quando os primeiros homens de Reiss adentram o terreno, vê-se o bando de primatas correr em direção ao desfiladeiro, fugindo do perigo que se anuncia. Caminhando mais atrás, Lara, Kosa, Reiss e o chefe de sua segurança presenciam os ataques das figuras monstruosas aos soldados apavorados. Os Guardiões, como sombras, ganham e perdem forma rapidamente. Alguns planos mostram seu tamanho e sua força, a bocarra repleta de dentes pontudos e os longos braços que lançam os homens de Reiss pelo ar e os levam para dentro das árvores e rochas, deixando para trás uma marca de sangue do tamanho de seus corpos. Imensas, aparecem e desaparecerem através das árvores mortas. De frente para o monstro, a câmera faz questão de mostrar um dos soldados de Reiss molhar as calças pouco antes de ser morto.

Ao ver Kosa começar a mover-se, Lara o para, avisando Kosa e o espectador que os Guardiões da Sombra parecem reagir ao movimento. Confirmando as suspeitas de Lara, um plano geral do terreno mostra vários deles desaparecerem no interior das árvores, tomando sua forma. Restam apenas Kosa, Lara, Reiss e o chefe de sua segurança. Reiss sabe que estão próximos ao local e para forçar Lara a mostrar como alcançá-lo ordena que Kosa siga em frente. O aliado de Lara começa a caminhar lentamente sob a mira da pistola de Reiss. Planos do rosto de Lara mostram o momento em que ela recorda-se das palavras do sábio da tribo, dizendo que a entrada da Origem da Vida seria revelada pelo orbe. A lembrança de Lara é construída pela voz do homem em off. $\mathrm{O}$ orbe aparece, então, através de um fade in, diminuindo até refletir num de seus olhos, entrando em sua pupila.

Lara pede, então, que Reiss lhe entregue a esfera, mas ele se recusa, dizendo-lhe que ela lhe diga o que fazer com ela. Lara toma a mochila que guarda o orbe de Reiss e sai correndo pelo terreno, sendo perseguida pelo chefe de segurança, que tenta impedila de prosseguir e recuperar o objeto. Os Guardiões das Sombras reaparecem, matandoo em seguida. Reiss, ao perceber que Lara se dirigia ao centro do terreno, a segue. Lara lança a esfera para dentro de um tronco baixo, em forma de vulcão. Os Guardiões se desfazem em frente aos seus olhos, o tronco desaparece, dando lugar a um buraco, por onde Lara e Reiss adentram a terra. Kosa fica para trás e pouco depois Sheridan chega ao local de helicóptero com Bryce e Hillary permanecendo na aeronave.

O desfecho da trama mobiliza, assim, todos os seus principais personagens. É no interior da Origem da Vida que Lara confrontará tanto Reiss quanto Sheridan. Reiss e 
Lara encontram a piscina de ácido onde a Caixa de Pandora flutua, iluminada com as mesmas cores do orbe. Reiss diz a Lara que como fora uma mulher a encontrar a Caixa no passado, ela é quem deveria retirá-la da piscina. Lara consegue desvencilhar-se dele, e enquanto Reiss a persegue pelos túneis rochosos do local, Sheridan os alcança, conseguindo tirar a caixa de seu leito. Sheridan assiste Lara e Reiss enfrentarem-se e quando Lara aparece sob a mira do adversário, o ex-namorado de Lara toma partido. Ela, contudo, consegue livrar-se de Reiss sozinha, fazendo-o cair no interior da piscina, enquanto logra segurar-se em uma das paredes de pedra e salvar-se. Reencontrando Sheridan, Lara crê que ele fora ao seu encontro para auxiliá-la. Contudo, Sheridan não admite deixar a Origem da Vida sem a caixa.

A sequência do confronto de Lara e Sheridan é dramática, pois é por meio dele que Lara prova seu valor como heroína. Diferente do que acontecera quando disputara com Powell o Triângulo da Luz, dessa vez seus interesses e emoções não são postos acima de sua missão. Lara tenta dissuadir Sheridan de levar consigo a Caixa de Pandora, em virtude da ameaça que ela representa. Ao contrário de Reiss, que vira no conteúdo da caixa a possibilidade de reinvenção da vida, como se ela fora o motor de uma nova Arca de Noé, Lara sabe que a liberação do conteúdo da caixa causaria a morte de milhares de inocentes. Sheridan se irrita com ela, contrapondo seus valores - que para ele são irreais - ao amor que supostamente ela sente por ele. Mas ao contrário do que crê Sheridan, Lara não o coloca em primeiro lugar. Ele, então, a agride fisicamente para mostrá-la que não poderá impedi-lo. O golpe é tão forte que ela cai no chão. A força física de Sheridan vem à tona, dessa maneira, como último recurso, ainda que ele esteja confiante que ela não o trocaria por seus princípios. A protagonista se levanta, limpando o sangue que escorre de seus lábios. Ela nega num sussurro, quase um soluço, e seu sofrimento é incontestável. Frente a frente, sem desviar o olhar do ex-amante um só momento, Lara o mata antes que ele consiga alcançar a pistola escondida às costas dele. A música ganha intensidade enquanto a imagem mostra, em câmera lenta, o corpo de Sheridan cair no chão.

Assim como Sheridan, Lara não sacrifica seus valores por amor. É evidente na sequência que Lara sofre ao ver-se obrigada a assassinar Sheridan, mas prova com isso que estava preparada para carregar o fardo solitário que sua missão implicava. É, portanto, através da morte de Sheridan que Lara se consolida como heroína: seu crime aparece plenamente identificado à justiça e às decisões corretas, que se colocam acima de qualquer sacrifício pessoal. Com o corpo pesado, Lara se dirige para o local onde 
Sheridan deixara a caixa, às margens da piscina. Um fade in a coloca ajoelhada a sua frente e o brilho do objeto parece hipnotizá-la. Lentamente, a tristeza de sua face transforma-se em admiração. Lara coloca as mãos sobre a tampa da caixa, que se move, deixando escapar um feixe luminoso de seu interior. Entretanto, Lara não se assusta. Ela ajusta a tampa da caixa, tampando-a novamente, e a devolve à piscina, submergindo em seguida. O poema de Hesíodo conta que Pandora, ao abrir o jarro, libertara dele todo o mal para o mundo dos homens, deixando dentro dele nada mais que a esperança, presa por uma tampa inquebrável no fundo do jarro ${ }^{50}$. O que se conta do mito de Pandora mais recentemente, nada diz sobre um compartimento secreto que escondia a esperança, apenas se diz que Pandora, ao chocar-se com o seu conteúdo, encerrara-a antes que ela pudesse ser libertada. Dessa forma, é possível depreender que Lara o tenha feito quando vê o feixe de luz escapar da caixa enquanto ela a manuseava na beira da piscina. De qualquer maneira, ao resistir à tentação de abri-la, subjugando a curiosidade feminina que fizera com que Pandora cumprisse os desígnios de Zeus sem saber que estava sendo usada por ele, Lara a redime ao devolver a caixa ao fundo de suas águas.

Ao deixar a Origem da Vida, Lara reencontra Kosa, o sábio da tribo e alguns de seus guerreiros. É dia e o homem lhe confirma que a caixa está finalmente segura. Lara retoma novamente o eixo da história, concordando que algumas coisas não devem ser encontradas.

Assim como em Lara Croft: Tomb Raider, a estrutura narrativa de Lara Croft Tomb Raider: A Origem da Vida também é linear, apresentando os acontecimentos que se passam na tela de forma consecutiva. Como acontece no primeiro filme da série, as "rupturas temporais" apresentam-se, através de diferentes estratégias, inseridas no presente da história. Mas diferente do que acontece no primeiro filme, as manipulações do tempo não o direcionam apenas ao passado, como quando Lara escuta a voz do sábio da tribo nos arredores da Origem da Vida, mas também em direção ao futuro. Isto acontece quando Lara ativa o orbe. Múltiplos fade in(s) são utilizados na construção da sequência na qual, ao fim de uma sucessão de planos que serão utilizados mais tarde também para compor as paisagens africanas do Kilimanjaro, um dos soldados de Reiss aparece sendo morto por um dos Guardiões das Sombras. Lara se assusta com estas imagens, parando a música que anima o orbe e interrompendo as imagens que dele emanam.

50 Hesíodo, "Works and Days", op. cit., p. 26. 
Outras manipulações do tempo da narrativa são construídas a partir da utilização da câmera lenta, que ora valoriza alguns movimentos de Lara em situações de combate, ora sublinha emoções mais intensas experimentadas pelos personagens, tal qual acontece em Lara Croft: Tomb Raider. Neste contexto, se no primeiro filme da série o recurso da câmera lenta aparecia mais associado à figura do pai de Lara, em A Origem da Vida a estratégia é mais utilizada para marcar momentos da interação entre Lara e Sheridan.

\section{O FEMININO E OS MASCULINOS DE LARA CROFT TOMB RAIDER}

Em relação às caracterizações dos grupos de personagens apresentados pelos dois filmes da série, há continuidades e descontinuidades. Em Lara Croft: Tomb Raider, o grupo de associados a Lara é formado principalmente por Hillary e Bryce. Os dois homens vivem na propriedade de Croft. Hillary, no entanto, usa um dos aposentos da casa, enquanto Bryce ocupa um trailer estacionado no jardim da mansão. O espaço ocupado pelo trailer estende-se por um pequeno jardim, demarcado por uma cerca de madeira. No interior do trailer, é possível ver uma série de aparelhos tecnológicos, como monitores, computadores, uma televisão e várias miniaturas de robôs eletrônicos, entre outros objetos. Sempre associada a algum tipo de tecnologia, a figura de Bryce aparece, especialmente no primeiro filme, como a de um nerd infantilizado: ele conversa com o robô que enfrenta Lara e com seus outros brinquedos, visíveis apenas no interior de seu trailer. Parece estar sempre distraído com algum aparelho, imerso em outros interesses, e não é raro vê-lo sendo apanhado de surpresa quando há qualquer demanda externa. Suas habilidades ficam, assim, muitas vezes omitidas por seu comportamento. Jocoso e mal-humorado, Bryce parece ser alguém mais adaptado ao mundo das máquinas que ao trato social ${ }^{51}$. Apesar disso, é ele quem acompanha Lara na viagem à Sibéria, mesmo que sua presença ali não pudesse ser mais que acessória: num espaço em que nenhum aparelho eletrônico funciona, a presença de Bryce mostra-se desnecessária. Em contrapartida, em Lara Croft Tomb Raider: A Origem da Vida, sua experiência em simuladores de vôo garante que ele assuma o controle do helicóptero

51 Uma proposição similar aparece em Blade Runner (Ridley Scott, 1982) em relação a J. F. Sebastian. A falta de trato social do jovem geneticista, portador da Síndrome de Matusalém, é exacerbada pela presença, em seu apartamento, dos bonecos construídos por ele para serem seus amigos. Ao contrário do que acontece com Bryce, entretanto, a aparência dos brinquedos de Sebastian remete ao passado, não ao futuro. 
com que Sheridan resgatara a ele e Hillary. Nesta ocasião, Sheridan diz que chegara a hora do personagem brincar de herói.

No que diz respeito ao trato social, Hillary é o oposto de Bryce. Sua função na mansão o transforma no portador de toda a etiqueta, preservando o lugar social que supõe que cada um deva ocupar. É nesta chave que lembra a Lara que uma Lady deveria ser discreta quando a vê exibindo-se, e cobra um distanciamento de Bryce dos assuntos privados de sua senhora. Apesar disso, a figura de Hillary tampouco é austera: dirige-se a Lara e Bryce com intimidade e ironia, é medroso, assustando-se com frequência. A maneira como ele meticulosamente se arruma para enfrentar os invasores da casa, associada à imagem dele calçando chinelos, colabora para que seu personagem seja construído na chave do cômico. Seu nome, atualmente mais utilizado como nome feminino, aponta tanto para a construção efeminada do personagem - que desaparece no segundo filme da série - quanto para a permanência de velhos valores no mundo em que Lara se origina.

Assim como acontece no jogo de videogame, Lara Croft é o único personagem feminino de importância nos dois filmes da série. Se em Lara Croft Tomb Raider: A Origem da Vida o lado dominatrix de Lara aparece mais marcadamente na sua relação com Sheridan, em Lara Croft: Tomb Raider os aspectos que podem fazer com que Lara apareça como um homem figurado são mais frequentes e acentuados, distribuindo-se por toda a narrativa. No que concerne a Hillary e Bryce, a construção de um Bryce mais infantil e de um Hillary mais efeminado em Lara Croft: Tomb Raider faz com que eles figurem como "homens incompletos", o que, em certa medida, pode colaborar para uma identificação de Lara a um personagem fálico, em cuja presença o masculino apresentase descaracterizado.

A relação de Lara com os dois homens - construída a partir de uma relativa intimidade - omite, em certa medida, a natureza das relações que a protagonista mantém com eles. Isto é válido especialmente em relação a Hillary, ao se considerar a sequência em que Lara aparece saindo do banho, enquanto é assistida por ele. O estranhamento causado pelo fato de Lara dividir um momento tão íntimo com Hillary aparece, então, reveladora de uma reminiscência de uma concepção aristocrática de serviço, em que a aproximação espacial entre nobres e criados ocorria simultaneamente com um rígido distanciamento social, muito semelhante àquele que se refere Elias, quando conta o caso da marquesa de Châtelet: 
(...) a marquesa ficava nua na frente do camareiro durante o banho, de maneira que ele ficava muito embaraçado, enquanto ela o repreendia, sem nenhuma consideração, por não ter despejado direito a água quente. Brandes, que cita essa passagem das memórias em seu livro sobre Voltaire, dá o seguinte esclarecimento: "Não a constrangia deixar-se ver despida por um lacaio; ela não o considerava um homem em relação a si mesma, como mulher". Um aspecto muito específico no comportamento dos cortesãos encontra explicação neste contexto. O mando constante sobre uma camada social, cujos pensamentos eram totalmente indiferentes para a camada dominante, permitia às pessoas desta classe aparecerem nuas diante de outras pessoas, por exemplo, enquanto se vestiam - mas também no banho, ou fazendo outras atividades íntimas - com muito menos consideração do que no caso de uma sociedade sem esse amplo substrato de criados. O nobre aparece, assim, despido, na frente de um serviçal, da mesma maneira que um rei aparece despido, se for o caso, na frente de um nobre ${ }^{52}$.

No caso de Lara, sua atitude para com Hillary não se baseia no desprezo a que Elias atribui o comportamento da marquesa e de outros membros da corte na época de Voltaire. O que se tem, então, é uma ambiguidade entre amizade e serviço, que recalca a distância social por meio de relações aparentemente íntimas. É importante perceber como, ao aceitar sua origem aristocrática, ainda que não se faça menção explicitamente $^{53}$ a isso em Lara Croft Tomb Raider: A Origem da Vida, neste filme os associados de Lara multiplicam-se. É neste filme, também, que a ambiguidade na maneira como Lara se relaciona com Bryce e Hillary aparece mais notadamente. Isto acontece quando Lara exige obediência imediata de Bryce quando ele contesta suas ordens, sem perceber que ele, rendido por Reiss e seus capangas, tentava impedi-la de revelar a localização da Caixa de Pandora para seus adversários. Mais tarde, Lara os defenderá como amigos, subjugando-se à chantagem de Reiss, ainda que motivada pela referência de Kosa sobre os perigos a serem enfrentados no caminho até a Origem da Vida.

A mesma ambiguidade entre amizade e serviço aparece em relação ao dono do barco grego e a seus filhos, mortos no início do filme, em relação à chinesa que guarda as motos e as armas de Lara e, finalmente, em relação a Kosa. É principalmente por

52 Elias, Norbert, A sociedade de corte, op. cit., 2001, nota 15, p. 294

53 A sequência que mostra Lara de volta à Mansão, após ser resgatada por Hillary e Bryce, mostra seu 
meio da participação de Kosa na última parte do segundo filme da série que a natureza de sua relação com estes diversos "amigos" se esclarece: guardiões de seus equipamentos em várias partes do globo, eles fornecem apoio operacional em suas empreitadas. Isso não impede que Lara os trate como amigos, o que, sem dúvida, mascara parte da natureza de suas relações.

No que se refere aos adversários da protagonista em Lara Croft: Tomb Raider, o filme constrói um grupo formado em torno de Powell que inclui seu assistente, o Sr. Pimms, o chefe do pequeno exército que o acompanha, Julius, e o saqueador de tumbas e antigo namorado de Lara, Alex West. Apesar de encontrar-se numa posição hierarquicamente inferior ao chefe do conselho dos Illuminati, Powell se apresenta como o grande adversário de Lara no primeiro filme. É ele quem tem como tarefa encontrar as metades do triângulo que proporcionarão aos Illuminati realizar a profecia. No entanto, Powell o faz com o intuito de usurpar o poder do Triângulo da Luz para si.

Powell é acompanhado durante toda a trama por Pimms. O assistente de Powell questiona por vezes as informações que Powell transmite ao chefe do conselho dos Illuminati, mas nunca suas ações. Já os outros dois colaboradores de Powell se apresentam como mercenários. Enquanto Julius fornece o poder bélico de Powell, comandando os soldados durante a invasão à Mansão Croft e aos templos do Camboja e da Sibéria, West é contratado por Powell para ajudá-lo a decifrar os esconderijos das duas metades do triângulo.

Já em A Origem da Vida, figuras de mercenários voltam a ser mobilizadas através dos personagens Chen e Xien Lo, chefes dos Shay Ling chineses, e de Sheridan. O principal associado a Reiss é, no entanto, o chefe de sua segurança, um personagem que não chega a ser nomeado durante a trama e que morre próximo à entrada da Origem da Vida. Frente aos grandes adversários de Lara Croft e a ela própria, a figura do mercenário emerge, nos dois filmes, como personagens cuja ambição pelo dinheiro os relaciona à violência, por um lado, ao exercer funções militares e, por outro, às atividades de pilhagem e/ou contrabando, alimentando um mercado por objetos raros. Lara, neste sentido, se diferencia do grupo de mercenários com que se depara, não apenas através de valores - como aponta Sheridan em Lara Croft Tomb Raider: A Origem da Vida - mas porque a falta de dinheiro não se impõe a ela como questão em nenhuma das duas narrativas. Neste sentido, a nobreza de Lara aparece na tela associada 
à riqueza e à abundância. Lara explora o passado visando a glória e a superação dos desafios. Nos termos de Max Weber, seu comportamento, assim, aparece motivado pela conquista de uma honraria, fundamento de sua situação de status, enquanto a que o comportamento dos mercenários - principalmente West e Sheridan, personagens mais elaborados nas narrativas - é motivado por questões estritamente econômicas, ou seja, por sua situação de classe. A partir daí, tornam-se mais evidentes as origens dos conflitos entre Lara e os dois ex-namorados. Diz Weber:

Em contraste com a "situação de classe" determinada apenas por motivos econômicos, desejamos designar como "situação de status" todo componente típico do destino dos homens, determinado por uma estimativa específica, positiva ou negativa, da honraria. Essa honraria pode estar relacionada com qualquer atividade partilhada por uma pluralidade de indivíduos e, decerto, pode estar relacionada com uma situação de classe; as distinções de classe estão ligadas, das formas mais variadas, com distinções de status. A propriedade como tal nem sempre é reconhecida como qualificação estamental, mas a longo prazo ela assim é, e com extraordinária regularidade. (...) Mas a honraria estamental não precisa, necessariamente, estar ligada a uma "situação de classe". Pelo contrário, normalmente ela se opõe de forma acentuada às pretensões de simples propriedade ${ }^{54}$.

No que se refere aos seus adversários, por meio dos objetos em disputa, Powell e Reiss buscam alcançar um poder ilimitado, poder este que aparece como capaz de pôr em risco toda a humanidade. Contudo, no caso de Reiss existe também uma motivação econômica por detrás de seus objetivos, algo que não aparece em relação à Powell. Entretanto, tanto Powell quanto Reiss mostram-se implacáveis: vilões por excelência, sua maldade é construída através do desprezo pela vida humana e pela consequente objetivação dos outros personagens com quem se relacionam. Talvez por isso, o relacionamento de Lara com seus colaboradores apareça nos filmes como amizade. Para além disso, no entanto, ao confrontá-los e impedi-los de alcançarem seus objetivos, Lara converte-se em defensora da humanidade.

Entre os personagens masculinos das tramas, os dois ex-namorados de Lara, Alex West e Terry Sheridan, se destacam, por trazerem elementos que ajudam a compor

54 Weber, Max. "Classe, estamento, partido". In: Ensaios de Sociologia. Rio de Janeiro: LTC: 2002, p. 131; grifos do autor. 
a importância da sexualidade de Lara para sua caracterização. Neste sentido, a sequência em que Lara procura West em Veneza, invadindo o quarto de hotel onde ele se hospeda é central. Nela, West escuta um ruído e, sentindo-se ameaçado, sai do banho. A sequência aparece como espelho daquela em que Lara toma banho, transformando o corpo masculino em objeto do olhar. West pega a pistola sobre a mesa. De posse dela, ele sente-se protegido e abre a porta do aposento, deparando-se com a camareira que, ao olhar na direção de seu pênis, grita ao vê-lo nu, indicando, assim, a potência de seu sexo, marca de sua virilidade. West, então, se depara com Lara sentada com os pés sobre a mesa. A reação de Lara em nada remete à reação da camareira, a potência de West não a "ameaça" ou incomoda. Visto por detrás da mesa, a arma de West substitui a parte que é escondida pelo móvel.
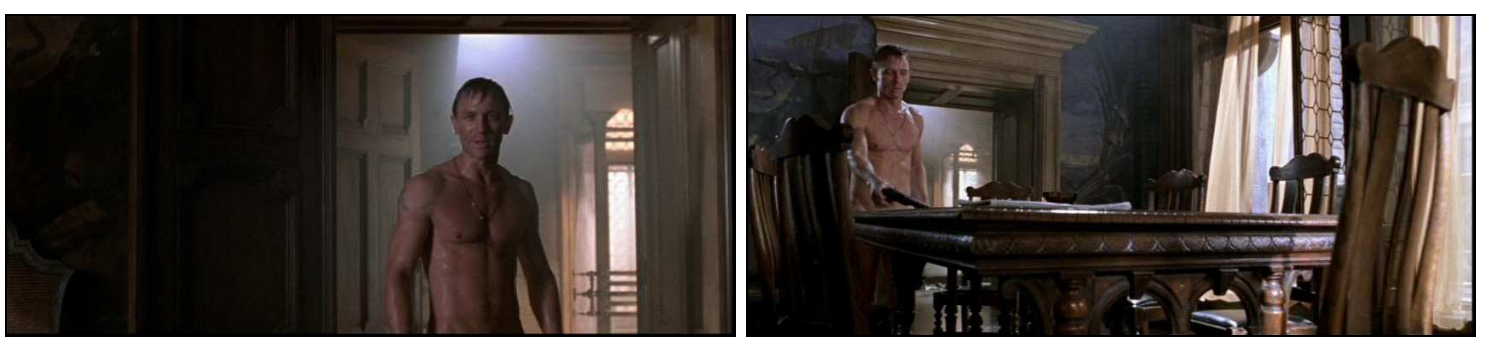

Lara acusa-o de traição, advertindo-o para o fato de que não poderiam voltar a ser amigos caso ele permanecesse aliado a Powell. Aqui, como em outros momentos da narrativa, o relacionamento íntimo dos dois é frequentemente invocado como forma de exprimir a diferença de valores entre os personagens. Lara, no entanto, não deixa de alimentar o desejo de West. Responde às investidas do ex-namorado com olhares sedutores. Ao fim desta sequência, Lara o provoca, admirando o seu corpo nu. O olhar de Lara excita West, que termina a sequência voltando ao chuveiro para tomar um banho frio. Em relação a West, esta é a sequência que mais exacerba o lado sedutor e provocante de Lara, inteiramente ancorado, na arte do coquetismo. West sente, como propõe Georg Simmel, o “jogo instável entre o sim e o não, uma recusa de se dar, que poderia ser muito bem a esquiva que leva à entrega" ${ }^{\text {"55 }}$. Lara não chega, com West, à decisão definitiva, permanece coquete ${ }^{56}$. Isto se dá, pois, segundo Simmel, "toda decisão definitiva põe fim à arte do coquetismo; por isso, ele manifesta a soberania de

55 Simmel, Georg. "Psicologia do coquetismo". In: Filosofia do amor. São Paulo: Martins Fontes, 1993, p. 97.

56 Basta lembrar que Lara só beija West quando ele morre. 
sua arte chegando bem perto de um definitivum, que contrabalança porém, a cada instante, por meio do seu contrário" ${ }^{\text {57. }}$

A sequência da interrupção do banho de West traz à tona a sexualidade de Lara também por meio do corpo de West, que se torna objeto do olhar e do desejo feminino. Da mesma maneira que a câmera evidencia as partes do corpo de Lara que despertam o desejo masculino, aqui ela mostra as formas masculinas que propõem um desejo feminino: a parte superior do corpo adornado com uma pequena tatuagem e algumas cicatrizes, a musculatura evidente nas costas, nos braços, no peito quase sem pelos e, finalmente, no baixo abdome.
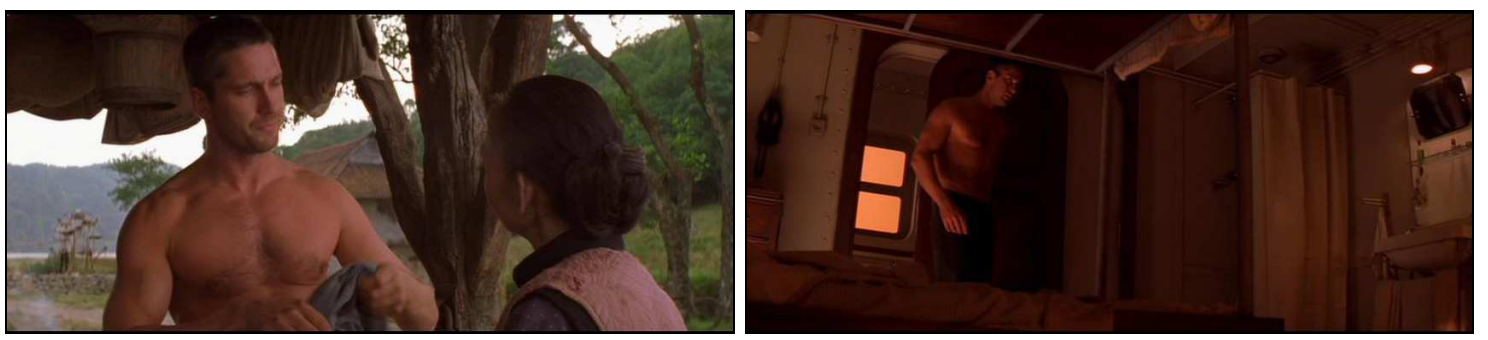

Também em Lara Croft Tomb Raider: A Origem da Vida o corpo de Sheridan objetiva-se frente à câmera, que insiste em apresentar planos de seus braços e dorso musculosos, despido ou despindo-se para ela. Contudo, Terry Sheridan, ao contrário de West, aparece, no início, associado a Lara em A Origem da Vida. O antigo relacionamento dos dois começa a ser construído já no reencontro dos personagens, na prisão do Cazaquistão. Após passar por várias celas coletivas, Lara e o guarda que a acompanha param em frente de uma pesada porta de ferro. O interior da solitária é monitorado por vídeo, mas a imagem que aparece mostra a cela vazia. Antes de abrir a porta, o guarda saca sua arma, esperando pelo pior. Lara entra e a porta se fecha atrás de si. Sheridan é visto fazendo flexões de ponta-cabeça, suspenso na grade que serve de teto à cela dele. Ele a reconhece imediatamente. Lara mostra-lhe umas chaves e ele lhe pergunta se são das portas do seu coração. Na negociação que culmina na adesão de Sheridan à busca pelo orbe, ele se aproxima provocativamente de Lara, que se afasta. A sequência propõe um personagem másculo e de grande força física, mas dotado de algum senso de humor.

Outros detalhes do relacionamento dos dois são fornecidos durante a viagem de Lara e Sheridan em busca dos Shay Ling pelo interior da China e em Xangai. Sheridan

57 Simmel, Georg, op. cit., 1993, p. 97 
primeiro a indaga sobre qual o significado do relacionamento dos dois para Lara; mais tarde, ela lhe pergunta o porquê de ele tê-la abandonado e desertado. Sheridan, então, diz que se sentira cansado de ser comandado, mas que sentiu mais a falta dela que de seus homens e da pátria. Para ele, os dois se complementam como os dois lados de uma mesma moeda. Lara parece discordar, mas fica evidente que havia se envolvido emocionalmente com Sheridan no passado. O reencontro dos personagens serve, portanto, a que eles se defrontem com seus sentimentos um pelo outro. Apesar disso, Lara parece decidida a matar Sheridan se ele se interpuser em seu caminho. Ela o ameaça pouco antes de serem feitos prisioneiros pelos Shay Ling. A busca pelo orbe em Xangai e em Hong Kong media, no entanto, a reaproximação dos dois.

Entre uma provocação e outra, Sheridan e Lara seduzem-se mutuamente. Sheridan parece compreender melhor a coqueteria de Lara, contudo, essa é a fonte de seu engano em relação a ela, pois Lara, apesar de seduzi-lo, não confia nele. Após invadirem o laboratório de Reiss em Hong Kong e recuperar o orbe, Sheridan se aproxima de Lara e a beija. A sequência que se inicia propondo a reconciliação do casal mostra uma Lara sexualmente dominadora, uma mulher que parece render-se, mas que no fim usa a sedução como arma.. Assim, Lara que inicialmente aparece debaixo de West, inverte as posições, para então, algemá-lo e confrontá-lo. Ela acredita que ele teve a chance de matar Reiss e não o fizera, por isso decide deixá-lo. Ele a contesta, dizendo que ela vai deixá-lo por medo de não conseguir matá-lo. Ela nega, reafirmando que poderia matá-lo caso ele tomasse a decisão errada.

O que Sheridan é incapaz de perceber é que, no momento em que Lara o adverte, ela não está mais jogando o jogo do coquetismo. Sheridan, contudo, continua no mesmo registro: ele acredita que ao dizer não, Lara quer dizer sim, assim como crê que suas diferenças podem torná-los "um”. Sheridan é, portanto, um personagem que joga o jogo do coquetismo, conhece seus termos, ao mesmo tempo em que faz uso do ideário relativo à complementaridade do casal heterossexual. Se a Lara de Lara Croft: Tomb Raider era puro coquetismo, a Lara de Lara Croft Tomb Raider: A Origem da Vida é o personagem que se utiliza do jogo como arma, mas também o supera. Por um lado, fica evidente, então, que a sedução para ela é um dos atributos que a caracterizam, estando relacionado mais com a maneira como ela exerce sua violência, que é o que por fim garante que alcance seus objetivos, do que com sua sexualidade ou suas relações amorosas. Por outro lado, Lara supera o jogo do coquetismo também porque com Sheridan toma a decisão definitiva. É isto o que mostra o último beijo do casal, que 
aparece numa chave completamente diferente daquele no navio de Hong Kong: Lara está entregue. No entanto, no momento em que ela abre-se à possibilidade de realização do amor, emerge a diferença mais brutal e impeditiva em relação ao seu parceiro. A morte deste amor não se dá pela realização do desejo, mas pelo imperativo da solidão que a transforma na heroína capaz de sacrificar tudo e de matar até mesmo aquele a quem ama.

A caracterização de Lara como heroína, assim, constrói-se diferentemente nos dois filmes. De um a outro, o personagem amadurece como tal. Em Lara Croft: Tomb Raider, o heroísmo de Lara aparece associado à herança e ao destino paterno que o personagem realiza. Já em A Origem da Vida, ao contrário, Lara converte-se em heroína de forma autônoma e consciente. Ainda que os assassinatos cometidos por Lara nos dois filmes apareçam como justiça e não como crime, seu conteúdo violento é inegável. Lara realiza a violência através do amplo domínio de seu corpo e de seu sexo. Habilidades de combate e sedução convertem-se, assim, nas principais armas de Lara Croft.

Violência e prazer aparecem associados em Tomb Raider, uma vez que é apenas através da violência que Lara alcança o êxtase. A violência se expressa através de seu corpo - é parte dele tanto quanto seus seios e quadril. As sequências que mostram Lara treinando se referem muito mais a um desejo de melhorar sua performance do que de apropriar-se de um conteúdo violento. Não há, assim, qualquer ambiguidade na maneira como a violência aparece através de sua figura. A reiterada erotização de seu corpo e suas ações evidencia o conteúdo sexual intrínseco à associação entre violência e poder que essas narrativas constroem, fazendo emergir uma mulher reinventada. No limite da sua identificação como tal, ou como seu contrário - uma dominatrix -, a figura de Lara dá forma a uma heroína que tem na sedução uma forma de poder. 


\section{Capítulo V - BeAtrix Kiddo}

Os dois "volumes" de Kill Bill têm como principal tema a vingança de uma mulher que acredita ter perdido sua filha ao final da gravidez em decorrência da tentativa de assassinato que sofrera. Bill, o pai da criança e chefe de um esquadrão de assassinos do qual o personagem fizera parte, tenta matá-la na capela em que se casaria com outro homem, em El Paso, Texas.

O motivo da vingança é dado a conhecer na apresentação de Kill Bill Vol. 1 (Kill Bill: Vol. 1, Quentin Tarantino, 2003). Após anunciar sua principal atração, um "velho provérbio Klingon" ocupa a tela: "A vingança é um prato que se come frio". Assim, o espectador é informado já nos seus primeiros segundos que Kill Bill trata-se de um filme de vingança. Em off, escuta-se a respiração ofegante de uma mulher, entrecortada por gemidos. Na sequência, a apresentação dará conta de relatar a ofensa, o ato que desencadeou a trama a ser assistida.

Em primeiro plano, um rosto de mulher ensanguentado e completamente deformado por ferimentos preenche a tela em preto e branco. É ela quem geme e seu corpo ofegante treme caído ao chão. Seus olhos se movimentam em direção à esquerda da tela, um deles está bem inchado, fechado em decorrência de um golpe. Do seu lado direito, percebe-se o tule de um véu de noiva manchado com sangue tremendo consigo. Ela está, no entanto, imobilizada devido à gravidade de seus ferimentos. Ouvem-se passos, a mulher sobressalta-se e olha na direção oposta. A câmera a abandona pela única vez nesta sequência e focaliza as botas de um homem que caminha da esquerda para a direita da tela. Assim, através da montagem dos planos, depreende-se que seu

1 A linguagem Klingon, ou a Língua do Guerreiro, foi criada pelo linguista Marc Okrand para os alienígenas dos filmes da série Star Trek (Paramount Studios) produzidos durante as décadas de 1980 e 1990. A referência à Língua do Guerreiro no início do filme nos ajuda a situar os personagens envolvidos na trama, qualificando-os como tais, de modo a que a referência à linguagem Klingon ultrapassa os limites do conteúdo do ditado que se apresenta sob diferentes formas em várias culturas. Como neste caso, os dois "volumes" de Kill Bill estão recheados por outras referências cinematográficas e televisivas, que se apresentam como pastiche, no sentido proposto por Fredric Jameson: "a canibalização aleatória de todos os estilos do passado, o jogo aleatório de todas as alusões estilísticas", que ocorre porque "os produtores culturais não podem mais se voltar para lugar nenhum a não ser o passado: a imitação dos estilos mortos, a fala através de todas as máscaras estocadas no museu imaginário de uma cultura que agora se tornou global". Jameson, Fredric. Pós-Modernismo. A lógica cultural do capitalismo tardio. São Paulo: Ática, 1996, p.45. É possível encontrar em diversas páginas na internet tentativas de localizar essas referências, muitas delas "inventadas" por fãs de diversas partes do mundo, obcecados por localizar o não-localizável. 
algoz se aproxima. Jean-Claude Carrière chama a atenção para que "a montagem possibilita uma relação altamente refinada entre o tempo e a duração", porque "a ação se move mais rápido que o filme. Situações, atos, palavras se escondem por entre os quadros",2 tal como ocorre nesta sequência da apresentação Kill Bill Vol. 1.

Novamente focalizando a mulher em primeiro plano, a câmera mostra a protagonista escutando o homem, enquanto ele limpa seu rosto cuidadosamente com um lenço branco em que se vê bordado o nome Bill. Informa-se, deste modo, que Bill é, portanto, o responsável pelas agressões, o que se confirma pelo diálogo que segue:

Você me acha sádico? Sabe, eu aposto que podia fritar um ovo na sua cabeça agora, se eu quisesse. Sabe, garota ${ }^{3}$, eu quero acreditar que você é capaz, mesmo agora, de perceber que não há nenhum sadismo nos meus atos. Talvez com esses outros palhaços, mas não com você.

A mão de Bill abandona o campo e sua voz sofre uma pequena alteração de tom enquanto percebe-se que o personagem se levanta. "Não, não, garota, neste momento estou sendo totalmente masoquista". Enquanto Bill fala, ouve-se o ruído de uma arma sendo munida e engatilhada. Percebendo o que viria a acontecer, a mulher fala pela primeira vez e com dificuldade: "Bill, o bebê é seu!". A revelação de que ele é o pai do filho que espera - a revelação mesma de sua gravidez naquele momento - se dá quase no mesmo instante em que o homem dispara sua arma em direção à cabeça da mulher. Ao som do disparo, a imagem é cortada e dá lugar a um fundo de tela negro em que se lê: “O $4^{\circ}$ filme de QUENTIN TARANTINO”. Um lamentoso solo de guitarra começa a ser ouvido. O desfecho da apresentação é anunciado pela música.

A seguir, a estrela é nomeada, Uma Thurman. Enfim, o título do filme: Kill Bill Vol. 1. Enquanto os demais atores são apresentados, uma voz feminina passa a acompanhar o solo da guitarra, e alguns deles são destacados como integrantes do Esquadrão das Víboras Mortais. Nesse momento, os nomes dos atores são acompanhados pelo nome de seus personagens, numerados como na lista de vítimas que a protagonista das narrativas fará mais tarde. Estes serão os principais personagens das

2 Carrière, Jean-Claude, A linguagem secreta do cinema, op.cit., p.107, 1995, p.120.

3 O grifo é meu. Neste e no diálogo seguinte, Bill refere-se a ela por Kiddo, dando a impressão de que a chama de garota, pirralha. Apenas em Kill Bill Vol. 2 saberá-se que Kiddo é, na verdade, o sobrenome do personagem. 
duas narrativas: Bill, chefe do esquadrão; Budd, seu irmão; as assassinas: Vernita Green, O-Ren Ishii e Elle Driver. Entre os personagens secundários com maior relevância no primeiro filme da saga, tem-se: Buck - enfermeiro do hospital em que a protagonista permanecera em coma, Sofie Fatale - advogada vinculada ao esquadrão - e Hattori Hanzo - antigo mestre de Bill. No segundo filme, o personagem secundário de maior destaque é Pai-Mei, mestre de artes marciais que ensina à protagonista a técnica com que finalmente assassina Bill.

A mulher reaparece caída ao chão como antes, o perfil de seu corpo estendido ocupa a tela. A canção faz menção a uma relação de violência e de abandono ${ }^{4}$. Por último, a equipe de produção é apresentada. A conclusão da apresentação é construída pelo corpo inerte ao chão e pela música de letra e melodia melancólicas. A protagonista está só com sua dor (estará viva ou morta?). O motivo da vingança é evidente. A imagem se dissolve. Fim da apresentação.

Diferente dos outros filmes analisados até este momento, a estrutura das narrativas fílmicas que contam a história de Kill Bill pode ser caracterizada, no que tem de mais geral, como não-linear, apesar dos filmes estarem divididos em capítulos numerados em ordem crescente. A sequência dos capítulos se refere aos vários episódios ou fatos, necessários à construção dos personagens e da trama da mesma história, mas esta sequência não se refere a acontecimentos consecutivos, encadeados linearmente no tempo.

A não-linearidade das narrativas é declarada ao espectador no início de cada um dos dois filmes. Em Kill Bill Vol. 1, isto ocorre indicialmente, já que o primeiro capítulo intitula-se 2 sem que até este momento saiba-se que se trata do assassinato da segunda pessoa da lista de vítimas da protagonista e da quarta pessoa a ser morta por ela após os acontecimentos mostrados na apresentação da narrativa. Apenas no fim deste capítulo, quando ela risca o nome de Vernita Green de sua lista é que podemos perceber que o número um da lista já foi morto, O-Ren Ishii. Em Kill Bill Vol. 2, na apresentação do

4 "I was five and he was six / We rode on horses made of sticks / He wore black and I wore white / He would always win the fight / Bang bang, he shot me down / Bang bang, I hit the ground / Bang bang, that awful sound / Bang bang, my baby shot me down. Seasons came and changed the time / When I grew up, I called him mine / He would always laugh and say / "Remember when we used to play? / Bang bang, I shot you down / Bang bang, you hit the ground / Bang bang, that awful sound / Bang bang, I used to shoot you down". Music played, and people sang / Just for me, the church bells rang. / Now he's gone, I don't know why / And till this day, sometimes I cry / He didn't even say goodbye / He didn't take the time to lie / Bang bang, he shot me down / Bang bang, I hit the ground / Bang bang, that awful sound / Bang bang, my baby shot me down"; Bang Bang (My baby shot me down), interpretada por Nancy Sinatra. 
filme, logo após a repetição de parte do curto diálogo que antecedera o tiro na apresentação do Vol. $1^{5}$, a protagonista declara estar se dirigindo a sua última vítima, Bill, quando até o fim do primeiro filme vimos os assassinatos de apenas duas pessoas de sua lista, Vernita Green e O-Ren Ishii.

Apesar das constantes "rupturas temporais", pode-se dizer que os capítulos são construídos de maneira linear. No primeiro filme a ocorrência de flashback(s) é recorrente, sendo marcada geralmente pelo mesmo som, semelhante ao de uma sirene. A trilha sonora utilizada para introduzir os flashback(s) causa uma sensação de confusão e de desnorteamento, como se as lembranças da protagonista a tomassem de assombro. Assim, eles tomam conta do personagem, interrompendo momentaneamente a linearidade do tempo da narrativa, mas reafirmando ou justificando repetidamente seus propósitos assassinos no presente da história. Isto ocorre porque neles lembra-se da participação dos outros personagens do esquadrão na ofensa que sofrera. Eles aparecem segundo o seu ponto de vista no momento da ofensa, com a câmera posicionada de baixo para cima, como se os visse desde o chão. Neste caso, a textura em vermelho reforça o sentido violento da ofensa, quanto as imagens do passado se presentificam.
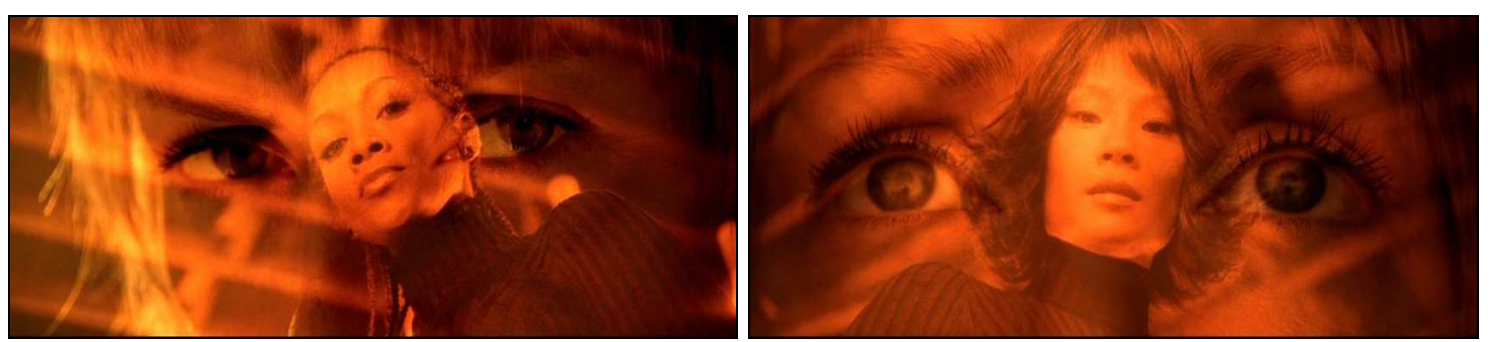

Uma exceção ocorre no segundo capítulo, A NOIVA ensanguentada, em que os flashback(s) justificam também o assassinato do enfermeiro do hospital. O personagem nada tem a ver com o esquadrão de Bill, mas é morto por promover e abusar sexualmente do personagem enquanto este permanecia em coma.

Jean-Claude Carrière afirma que o flashback é uma técnica narrativa que,

primeiro nos mostra algo, alegre ou triste, acontecendo no presente, e depois nos joga ao passado para procurar as origens desta ação - como se

5 Neste caso, enquanto ouve-se a voz de Bill, a protagonista aparece apenas pouco antes de revelar que o filho que espera é dele e ser alvejada. A trilha sonora que acompanha a sequência é diferente da utilizada no primeiro filme, propondo tensão. 
remássemos de volta contra a corrente num rio causal - , antes de nos devolver ao fim da história que o filme está contando ${ }^{6}$.

Em Kill Bill Vol. 1 os flashback(s) são construídos visualmente através da utilização de fade in(s), que marcam a mudança de temas que, no entanto, são antecipados pelo som. Em Kill Bill Vol. 2, essa mesma trilha sonora é utilizada uma única vez para marcar a participação de Elle Driver na ofensa. O som remete, assim, diretamente aos flashback(s) do primeiro filme e, apesar do tempo da narrativa não ser interrompido pela imagem de Elle na situação da ofensa, a trilha sonora confirma sua participação. Em Kill Bill Vol. 1, o mesmo acontecera a Sofie Fatale, mas antes a protagonista já recordara sua participação no massacre, ao vê-la dirigindo seu carro enquanto falava ao celular, lembrando-se do modo como Sofie atendera ao telefone enquanto ela era espancada. Sofie Fatale, apesar de haver participado do massacre, não consta da lista de vítimas da protagonista, o que demonstra que seus planos iniciais já consideravam utilizá-la como informante. Além disso, a maneira como a memória da protagonista interrompe o tempo da narrativa quando vê Sofie Fatale dirigindo, mostrando sua participação no massacre, será a estratégia mais explorada de "interrupção" do tempo da narrativa no segundo filme.

As dissoluções marcam os principais recortes temporais de Kill Bill Vol. 1, sendo utilizados tanto no fim de cada capítulo quanto em suas subdivisões, como acontece no segundo capítulo. Este capítulo relata parte dos acontecimentos relacionados ao massacre de El Paso e divide-se em duas partes.

A primeira parte do capítulo relata como a protagonista foi encontrada após o massacre. Quatro anos e meio antes de acordar no leito do hospital, a mulher - que acredita ser a única sobrevivente do massacre - e mais oito corpos são encontrados em uma capela em El Paso, Texas. O filho do xerife responsável pelo caso, também policial, acredita que o nome utilizado por ela, Arlene Machiavelli, seja falso. O xerife, a partir da cena do crime, sustenta que o massacre tenha sido executado por quatro ou cinco profissionais, provavelmente da máfia mexicana. As percepções do xerife introduzem, assim, o primeiro vínculo entre a lista de vítimas da protagonista e o massacre. $\mathrm{O}$ corpo da mulher estendido no chão, como na apresentação, é transportado através de um fade in para um leito de hospital, onde permaneceu em coma. As cores

6 Carrière, Jean-Claude, A linguagem secreta do cinema,op. cit., p.123. 
predominantes das duas cenas migram das tonalidades de vermelho - sangue, perigo, destruição - para as de azul - limpeza, tranquilidade, introspecção, isolamento. Durante o período em que permaneceu em coma, nada mais descobriram a seu respeito, o que é confirmado através da lembrança da mulher a respeito de Buck, o enfermeiro. Ele a chama de Jane Doe, nome utilizado nos países de língua inglesa para designar mulheres de identidade desconhecida em hospitais e necrotérios.

O capítulo relata também como Bill desistiu de assassiná-la enquanto ela permanecesse em coma. Após o massacre, Elle Driver, vai ao hospital para tentar matála, no que teria sido bem-sucedida se não tivesse sido impedida por um telefonema de Bill. O mandante desistira de matá-la naquelas condições, já que fazê-lo o rebaixaria. Elle Driver deixa seu quarto alertando-a para nunca acordar. Até este instante está claro que a protagonista integrava o esquadrão de Bill e era também sua amante, mas os motivos que desencadearam as ações de Bill para matá-la não são mostrados no decorrer de todo o Vol. 1. A inserção de Elle Driver na trama esclarece a respeito da relação que as outras integrantes do esquadrão mantêm com Bill. Ao telefone, o personagem diz que a ama e pede para que Elle volte para casa. Bill revela-se, através do telefonema, um homem poderoso e manipulador. Além de ser o chefe do esquadrão, parece dominar as mulheres ao seu redor pela sedução. E ainda que possa-se depreender que a protagonista compartilhava com ele uma relação mais intensa - dada a força de sua investida contra ela e das insinuações de Vernita no primeiro capítulo - e que Elle Driver a teria substituído como amante de Bill, o que parece claro apenas é o grande domínio que Bill exerce sobre as integrantes do esquadrão.

A segunda parte do capítulo relata como a protagonista saiu do coma e fugiu do hospital. Ao acordar, a protagonista lembra-se do momento em que é alvejada por Bill e se dá conta de maneira dramática que não está mais grávida. Em seguida, analisa as linhas da mão e conclui que se passaram quatro anos desde o tiro. Este saber misterioso sobre o tempo que se passou não é mais explorado pelo filme, mas aponta que o personagem tem um certo contato com o segredo e o mistério, o que se confirmará no Vol. 2 pelo uso da Técnica dos Cinco Pontos que Explodem o Coração. O uso de técnicas misteriosas por heróis de "filmes de kung fu" é bastante comum e aparece geralmente associada à prática dos mais altos níveis das artes marciais ${ }^{7}$. Não acredito

7 Cf. Anderson, Aaron. "Mindful violence: the visibility of power and inner life in Kill Bill”. In Jump Cut: A Review of Contemporary Media, No. 47, disponível via URL em: http://www.ejumpcut.org/archive/jc47.2005/KillBill/ text.html, acessado em 24/04/2006. 
que seja possível nem desejável classificar os "volumes" de Kill Bill como filmes de kung fu simplesmente. No entanto, ao relacionarem-se as duas sequências, percebe-se que a protagonista detém poderes que a distinguem dos outros personagens da trama, porque advêm do segredo, do mistério, de uma relação com o extraordinário. Esta relação é, no entanto, pouco visível. A protagonista não é construída como uma superheroína, cujos poderes são fantásticos. O que ela pode e não pode fazer não se distingue em grande medida do que podem fazer os outros personagens com quem se relaciona na trama. Isso não significa que os dois "volumes" de Kill Bill não apresentem uma dimensão fantástica e extra-ordinária, mas sim que essa dimensão não é prerrogativa exclusiva da protagonista.

As dissoluções também marcam a transição dos capítulos em Kill Bill Vol. $2^{8}$, mas os cortes temporais são construídos de maneira diversa em relação ao Vol. 1 . O recurso do flashback marcado pelo uso do fade in no Vol. 1 é substituído pela montagem direta no Vol. 2 em quase todos os casos em que o salto no tempo parece ser maior. Deste modo, a narrativa confunde tempos diversos, reiterando a presença do passado no presente. O espectador é preparado para estes saltos no tempo entre os capítulos 6 e 7, que trazem tanto o uso da dissolução - ao deixar a capela de El Paso e conduzir a narrativa para a região árida e montanhosa da Califórnia onde Bill encontra seu irmão, Budd - quanto o uso da montagem direta - ao apresentar o próximo capítulo.

A presença da memória como reminiscência do passado no presente se dá a ver quando Elle Driver relata, no capítulo 9, ELLE e eu, os motivos que levaram Pai Mei a cegá-la de um olho e como ela se vingara, envenenando-o; bem como quando a protagonista conta a Bill como descobrira estar grávida durante sua última missão no capítulo final, Cara a cara. Nestes momentos, os personagens narram os fatos enquanto, por meio das imagens, o espectador converte-se em testemunha dos acontecimentos. É desta maneira que o passado da memória presentifica-se na narrativa.

Já o fade in é utilizado apenas em cortes temporais menores no interior dos capítulos, como no capítulo 9, quando a protagonista percorre o deserto e as montanhas da Califórnia até chegar ao local onde está estacionado o trailer onde vive Budd e

8 Exceto pela transição entre os capítulos 6, Massacre em Two Pines, e 7, O túmulo solitário de Paula Schultz, realizada pela montagem de planos sem o uso da dissolução. O fím do sexto capítulo apresenta Bill alertando Budd sobre os planos de vingança da protagonista. Já o início do sétimo apresenta Budd chegando ao trabalho, numa boate de striptease. Neste caso, a transição aponta para um salto menor no tempo da narrativa. De forma contrária, o diálogo entre Bill e Budd no final do capítulo 6 é introduzido por uma dissolução, que separa o dia do massacre do momento da advertência de Bill. 
enfrentará Elle Driver. Neste caso, os sucessivos fade in(s) aceleram o tempo da narrativa enquanto a protagonista atravessa o deserto californiano, do mesmo modo que reforçam a persistência e a obstinação do personagem: ela segue seu curso, não desiste, mesmo exausta, suja e ferida. Essa presença fantasmagórica se humaniza na medida em que se percebe sua aproximação, ao mesmo tempo em que a sequência colabora na composição de um personagem dotado de uma força extraordinária.
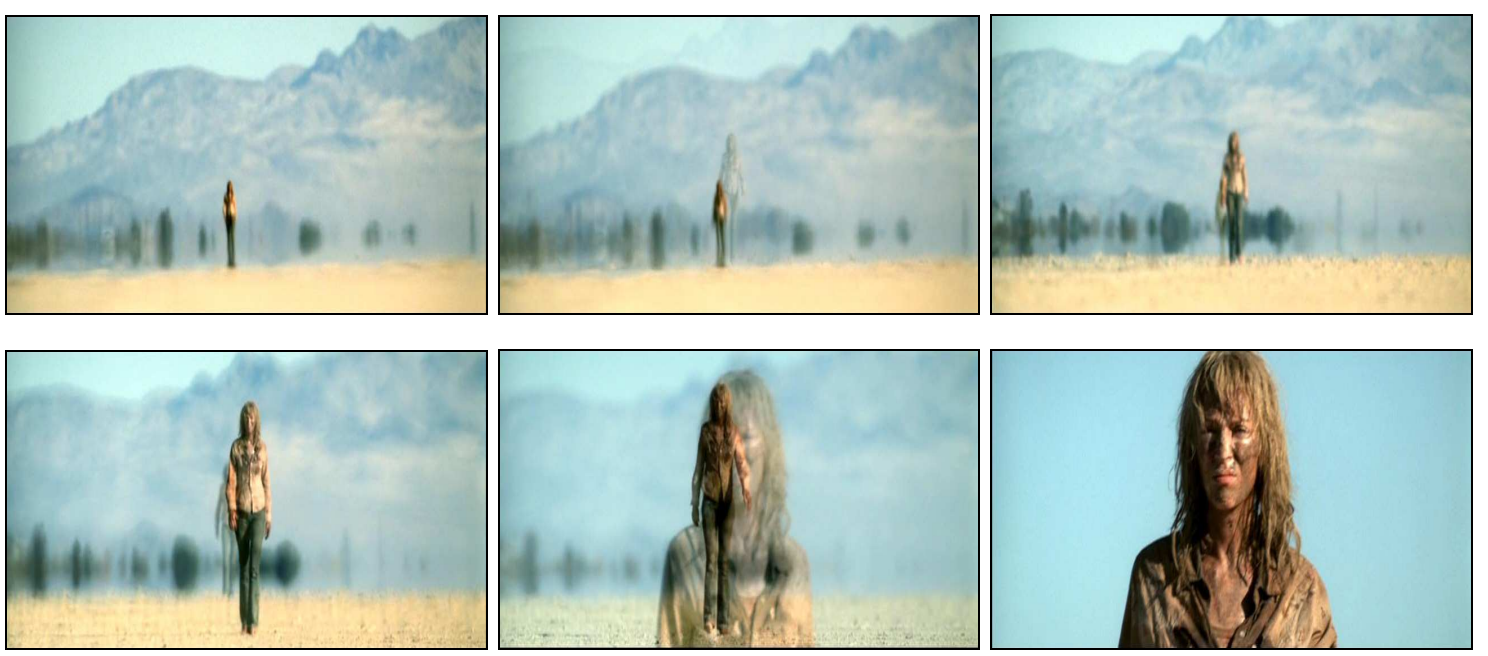

Os principais recortes espaciais dos filmes são construídos como desertos. Sabese que parte da história se passa nos estados norte-americanos do Texas e da Califórnia, através das referências a nomes de localidades como El Paso, Two Pines, Pasadena e Barstow. Há pouca ou nenhuma vida circundante nos cenários utilizados, de modo que a trama e seus personagens se apresentam quase sempre isolados. Panoramas de regiões áridas são mostrados para compor os espaços das ações e, neste sentido, o Texas e a Califórnia se distinguem pelo relevo e não por seu povoamento. Enquanto o Texas é apresentado como planície, as imagens da Califórnia exploram montanhas e vales.
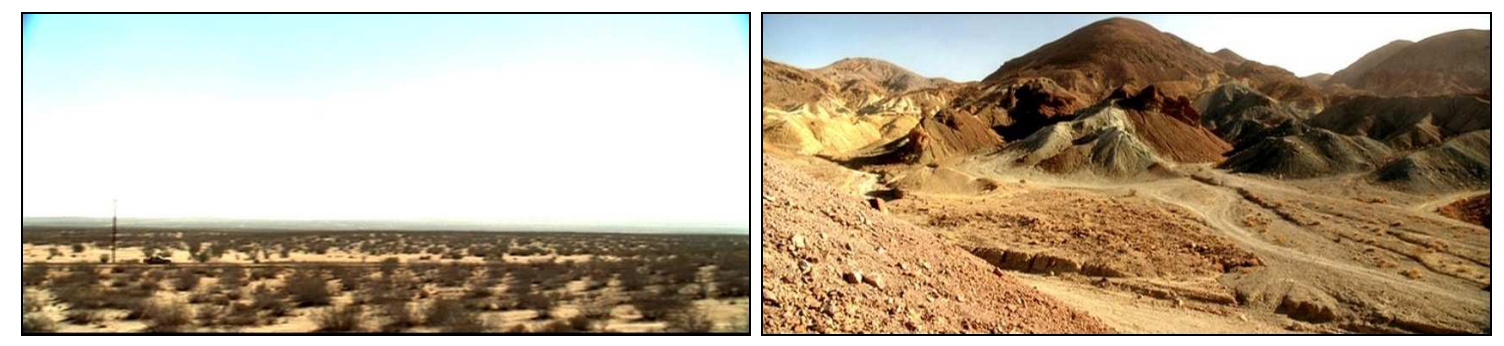

Texas

Califórnia 
O deserto se transporta aos cenários urbanos: nenhum vizinho dos Bell é visto em Pasadena, nenhum cliente está no café próximo ao cemitério em Barstow, tampouco na boate onde trabalha Budd. Alguma vivacidade é emprestada aos cenários da capela, do hospital, do guichê do aeroporto e da boate pela presença de poucos figurantes que, apesar de aparecerem como parte do cenário, chamam a atenção por serem pouco vistos nos dois filmes. Assim, mesmo quando o panorama deixa de ser o do deserto, este é o grande panorama da trama quando o espaço construído pelas narrativas é o deste Estados Unidos mostrado nos dois "volumes" de Kill Bill.

Os dois filmes trazem ainda dois recortes espaciais secundários, em suas construções do Japão e do México. Em primeiro lugar, é também a paisagem que distingue a construção do espaço elaborado como México. E apesar de pouco explorado, pode-se dizer que este México esteve presente nos dois filmes. Saberá-se que o México é o país de origem de Bill apenas no Vol. 2, enquanto, no primeiro, o xerife atribui a autoria do massacre à máfia mexicana. Além disso, na animação que conta a história de O-Ren Ishii, um de seus governantes é mostrado sendo assassinado por ela, acompanhado pelo que parece ser duas prostitutas. Assim, lugar de criminosos e prostitutas, o México é também o local em que os figurantes interagem com a câmera, participam da ação, abrindo portas ou simplesmente encarando a câmera e a protagonista. Neste sentido, a presença dos figurantes é menos acessória no espaço construído como México, já que os demais personagens interagem mais com eles que nos outros recortes espaciais.

As viagens da protagonista para o Japão no Vol. 1 - primeiro para Okinawa e depois para Tóquio - são construídas a partir de um balcão de venda de passagens branco e vermelho, possivelmente um guichê de aeroporto, que dá lugar ao bilhete de passagem aérea do qual sai um avião que percorre um mapa animado, cujos alvos são as cidades a serem visitadas por ela. No capítulo 4, O HOMEM de OKINAWA, a protagonista encontra-se com Hattori Hanzo, que lhe confecciona uma espada de samurai $^{9}$ - a arma que utiliza para assassinar O-Ren Ishii no Vol. 1. Neste capítulo, é

9 Neste capítulo, bem como no capítulo final, Cara a cara, a protagonista comunica-se em japonês. Fundamentalmente é o conhecimento da língua japonesa que lhe garante o acesso ao mundo de Hattori e do Japão tradicional. Em contrapartida, ser fluente em japonês não lhe garantira ser bem recebida por Pai Mei, lendário mestre chinês dos segredos do Kung Fu, como é mostrado no capítulo 8, O treinamento cruel de Pai Mei. Se, por um lado, o domínio de línguas orientais aparece, portanto, como via de acesso ao mundo das artes marciais, por outro, a tentativa da protagonista em comunicarse com Pai Mei em japonês reflete seu desconhecimento da tradicional disputa entre os dois países, converte-se em gafe e justificativa para a irritação de Pai Mei em relação a ela. 
interessante perceber como os interiores do restaurante e do sótão de Hattori Hanzo são suficientes para propor um primeiro Japão, o da pureza, da tradição e da honra.

Já no capítulo 5, Confronto na Casa das Folhas Azuis, Tóquio é mostrada externamente desde o sobrevoo do avião onde viaja a protagonista. O segundo Japão construído a partir de Tóquio traz as marcas da contemporaneidade. Grandes edifícios, muita publicidade, extensas avenidas e túneis mostram a cidade. A contemporaneidade japonesa é caracterizada fundamentalmente pelo conflito com as tradições, foco central da caracterização de Okinawa. A corrupção, a perversão dos costumes e as relações capitalistas que permitem que estrangeiros ocupem lugares de destaque - especialmente no mundo do crime, através da figura da própria O-Ren Ishii - marcam as tensões entre o Japão moderno e o tradicional. A máfia japonesa torna-se visível pelo deboche, pela violência e pela disputa de poder.

A partir deste espaço, o quinto capítulo relata a empreitada da protagonista para assassinar O-Ren Ishii, a primeira vítima de sua lista. Para chegar até O-Ren, ela tem de exterminar quase todo o seu exército pessoal antes, já que O-Ren se tornara chefe da máfia japonesa em Tóquio. Vários novos personagens são apresentados neste capítulo e entre eles, Sofie Fatale, a única ex-integrante do esquadrão que é poupada da morte em Kill Bill Vol. 1, com o intuito de levar informações sobre a protagonista e seus planos de vingança diretamente a Bill. Como Sofie Fatale, os demais servem a O-Ren em Tóquio. Entre eles, dois se destacam, Gogo Yubari - uma jovem assassina caracterizada pela protagonista como tendo insanidade de sobra para a pouca idade, 17 anos - e Johnny Mo - general do exército de O-Ren, Os 88 Loucos. Ambos desafiam suas habilidades, tornando sua missão mais difícil. Assim, o personagem só consegue aproximar-se de ORen após matar Johnny Mo, um dos últimos a cair.

O segundo massacre do filme suspende completamente o tempo da narrativa, os acontecimentos de uma noite são estendidos ao máximo de modo a transformar sua grande batalha no principal acontecimento do primeiro filme. $\mathrm{O}$ alongamento do tempo da narrativa manifesta-se também na duração deste capítulo. Enquanto todos os outros capítulos juntos mais a apresentação somam aproximadamente 58 minutos de filme, o capítulo 5 dura cerca de 45 minutos, dos quais 20 deles relatam o massacre promovido pela protagonista na Casa das Folhas Azuis. De acordo com Carrière, 
thrillers, por exemplo: o punhal voa em direção à garganta e - sem recorrer à câmera lenta (...), uma vez mais utilizando um simples truque de montagem, através de uma sequência de tomadas alternadas, o punhal nunca encerrando seu voo nem a garganta, o seu oferecimento ao sacrifício - o tempo se arrasta indefinidamente, e por vezes parece parar para estimular nossa sensação de angustiada expectativa. Prendemos a respiração, o próprio tempo fica paralisado ${ }^{10}$.

O confronto na Casa das Folhas Azuis é construído como massacre não só pela quantidade de mortos, mas porque em dado momento, como na apresentação do massacre de El Paso, a narrativa é feita em preto e branco. A passagem das imagens em cores para as imagens em preto e branco ocorre quando a protagonista fere os olhos de um dos soldados de O-Ren ${ }^{11}$. A partir deste momento, o personagem passa a lutar automatamente. A luz estourada da sequência fixa-se nela, enquanto os soldados de ORen envolvem-se pela penumbra. O transe acaba quando o personagem se vê mais uma vez encurralado. Um primeiro plano de seus olhos capta o momento do despertar, em que se vê obrigada a pensar rápido em uma nova estratégia de combate. Ao piscar como se tentasse recuperar a visão - a película recupera as cores, mas o cenário é mergulhado numa escuridão de tons de azul e negro. A dona do restaurante desliga a luz.

A narrativa do primeiro filme utiliza-se de dois narradores. Ambos são personagens do filme, mas enquanto narradores suas vozes destacam-se em off. Os narradores também desempenham funções diferentes, apesar de que suas aparições ilustram mais do que conduzem a narrativa. O primeiro narrador é a própria protagonista que, em algumas situações, introduz novos dados sobre suas vítimas ${ }^{12} \mathrm{e}$ outros detalhes da trama. O segundo narrador é Hattori Hanzo, mestre japonês na confecção de espadas de samurai. Diferentemente da narração da protagonista, Hattori faz considerações "filosóficas" sobre os desígnios do personagem central da narrativa,

10 Carrière, Jean-Claude, op.cit., 1995, p.118; grifos do autor.

11 Em El Paso é a protagonista quem tem um dos olhos feridos. A película em preto e branco parece relacionar a ausência de cores à cegueira do campo de batalha.

12 Como no capítulo 1, enquanto a protagonista e Vernita Green dirigem-se a cozinha, sua voz em off relata que as duas se conheciam antes do massacre de El Paso. Ela também dá detalhes sobre si mesma e sobre Vernita, como seus codinomes - Mamba Negra e Cabeça de Cobra, respectivamente enquanto membros do Esquadrão de Víboras Mortais e o nome atual de sua vítima, Jeanne Bell, e de seu marido, o médico Lawrence Bell. No capítulo 3, é também ela quem relata os acontecimentos que levaram O-Ren Ishii a tornar-se uma grande e destemida assassina. 
explicando ou mesmo justificando seus atos. Sua primeira aparição como narrador aparece logo após o assassinato de Vernita Green, enquanto a protagonista volta à Pickup das Gostosas ${ }^{13}$. Hattori afirma neste momento, em japonês, que para um guerreiro em combate, matar seu inimigo é a única preocupação, para isto devendo suprimir toda emoção humana e compaixão, e matar quem mais estiver em seu caminho. Neste momento, Hattori ainda não é um personagem conhecido, sua primeira aparição como personagem se dará apenas no capítulo 4. Para marcar sua identificação também como narrador, sua imagem aparece durante a cerimônia de entrega da espada à protagonista em Okinawa, no fim do capítulo 5, enquanto sua voz em off explica que, "a vingança nunca é uma linha reta. É como uma floresta, onde é fácil perdermos o rumo e esquecermos por onde entramos". Na sequência, a protagonista aparece escrevendo sua lista no avião, ao lado de sua espada ${ }^{14}$.

Kill Bill Vol. 1 é um filme de poucos diálogos e talvez por isso tenha sido feita a escolha pela narração como uma das estratégias para a proposição dos seus sentidos. Já a narrativa do Vol. 2 explora mais os diálogos que a narração. Ainda assim, ela se fez presente em alguns momentos, como no capítulo 6, Massacre em Two Pines, em que a protagonista apresenta os detalhes do massacre de El Paso, bem como quando as recordações são narradas por Elle Driver e pela protagonista.

Os dois "volumes" de Kill Bill exploram ao máximo o poder do close-up, especialmente dos olhos e do rosto dos personagens, mas também de seus pés - como na sequência do segundo capítulo que mostra o esforço da protagonista em sair da entropia no interior da pick-up estacionada nas dependências do hospital. A montagem de diversos primeiros planos de seu rosto e de suas mãos contrapõem sua força e determinação aos seus pés imóveis.

Já a montagem dos dois filmes explora ora planos curtos, ora planos de duração média. Planos de pés destacam o movimento dos personagens em direção à ação, enquanto close-up $(s)$ faciais dão conta das emoções dos vários integrantes da narrativa. Em situações de confronto a protagonista ora parece engrandecida, focalizada de baixo para cima, ora encurralada, quando focalizada de cima para baixo. Quando em combate

13 Veículo utilizado por ela durante os capítulos 1 e 2, roubado de sua primeira vítima, o enfermeiro, Buck.

$14 \mathrm{O}$ aumento da restrição de itens que poderiam ser transportados no interior das cabines de aviões comerciais que foi implementada, em âmbito mundial, após os ataques de 11 de setembro de 2001, faz com que a sequência torne-se bastante curiosa, ainda que o transporte de objetos pontiagudos nestes espaços há muito já não era permitido. 
corpo a corpo, as câmeras alcançam, no máximo, a altura de seus ombros. $\mathrm{O}$ diretor e sua equipe exploram recursos variados, como o uso de animações. No entanto, chama atenção a maneira como as narrativas dão forma a determinados acontecimentos. Se as narrativas ora se utilizam de estereótipos reconhecíveis ao espectador - como na caracterização das prostitutas ou na coreografia dos enfrentamentos - elas também propõem outros, como a do sangue das vítimas que atinge as faces dos personagens, em trajetórias retilíneas para cima ou para baixo. Neste sentido, os filmes dialogam com ao mesmo tempo que evidenciam - algumas características da linguagem cinematográfica contemporânea, reiterando sua capacidade de dar uma feição a ações, comportamentos, movimentos e acontecimentos, bem como de manipular o tempo da narrativa, a partir de certas escolhas nas proposições de seus sentidos.

É dessa maneira que é dado a ver e a perceber a história desse personagem que só existe nas narrativas para vingar-se daqueles que o ofenderam. Sua história pessoal só é mostrada no que se relaciona aos seus propósitos e, portanto, ela só existe na narrativa como instrumento de vingança.

A vingança proposta em Kill Bill não visa igualar a retaliação à ofensa sofrida pela protagonista. Isso fica claro já no capítulo 1, quando afirma à Vernita Green que, para fazê-la pagar na mesma moeda, ela deveria matar não apenas Vernita, mas também sua filha e seu marido. Tampouco a protagonista concebe sua vingança em maior intensidade que a ofensa sofrida. A morte de seus agressores é resultado do confronto físico e não de artifícios criados para fazê-los sucumbir após longo sofrimento. Tais características emprestam certa dignidade aos seus propósitos, diferenciando-a de adversários como Budd e Elle Driver.

O personagem de Budd aparece pela primeira vez ao final do primeiro filme, afirmando que a protagonista merece sua vingança e que os membros do esquadrão merecem morrer. O diálogo ampliado é reinserido no segundo filme, quando Budd nos lembra que ela também merece morrer tanto quanto eles. Como já foram apresentados os detalhes a respeito do massacre, sabe-se que os acontecimentos de El Paso constituíram-se como a vingança de Bill por ela tê-lo abandonado e deixado que ele acreditasse que estava morta. A apresentação da continuação do diálogo de Budd chama atenção para o fato da protagonista também ser uma assassina que, enquanto membro do esquadrão de Bill, não se distinguia dos demais. No entanto, Budd e Elle almejam matá-la da maneira mais dolorosa possível, um anseio não compartilhado por ela. 
Tendo como principal mote sua vingança, a maior parte das situações criadas pelo enredo são de desafio. $\mathrm{O}$ que atribui maior significado à sua vingança é, apesar disso, o fato da ofensa acarretar a presumida perda de seu bebê, já que em nenhum momento a protagonista lamenta a morte do noivo e das outras vítimas do massacre de El Paso. Sua vingança resulta, portanto, da carência advinda de uma ofensa à maternidade. No entanto, a protagonista não se vinga apenas de Bill e seus comparsas. A morte de Buck, e mesmo sua presença na trama, chama a atenção para que a vingança levada a cabo pela protagonista está vinculada à sua sexualidade, a qual a maternidade apresenta-se como parte primordial. Ela não se vinga simplesmente porque tentaram assassiná-la, mas sim porque foi atingida naquilo que a distingue como mulher: a gravidez e o estupro. É apenas a partir de sua sexualidade que essa mulher pode ser atingida, sua fraqueza tem a ver, portanto, com seu sexo e não com sua capacidade de matar. Assim, se por um lado, os filmes publicizam abusos sofridos por mulheres físico e sexual -, eles também evidenciam que o que as tornam frágeis é justamente o seu sexo. No entanto, essa é uma relação que não aparece sem mediação. Ao atentar-se para o fato de que foi justamente seu sexo que garantiu a O-Ren vingar-se daquele que matara sua família, perceberemos que a sexualidade feminina aparece em Kill Bill não apenas como fragilidade, mas também como uma arma.

A vingança que é dada a ver em Kill Bill aparece, portanto, como uma vingança feminina. Isto porque as agressões sofridas pelos personagens ou se referem à violação de corpos femininos ou à violação da família ${ }^{15}$ - violações do mundo privado, entendido aqui como tradicionalmente concebido como o mundo das mulheres. O crime contra a família, contra o sangue familiar que jorra por todos os lados e espirra nas faces dos personagens, só pode ser expiado nos dois filmes através da vingança. E para isso, a revanche se dá pelo derramamento de sangue de outras famílias, se retro-alimenta, não tem fim. A vingança é, portanto, da ordem da vida privada, porque o Direito pouca ou nenhuma influência desempenha na estrutura das narrativas.

É a partir desse contraste que são construídos os personagens de Kill Bill. Todas as integrantes do esquadrão, bem como Gogo Yubari, se apresentam tão capazes de matar ou lutar quanto qualquer um dos personagens masculinos de destaque nas narrativas e, em certa medida, se apresentam ainda mais poderosas que eles, demonstrando na tela habilidades que os personagens masculinos não exibem. No

15 Como no caso da história de O-Ren Ishii, relatada no capítulo 3, bem como na possibilidade de Nikki Bell vingar a morte da mãe. 
entanto, e curiosamente, apenas em Kill Bill Vol 1 a protagonista enfrenta e combate homens "de igual para igual", mesmo quando se considera que eles eram todos subordinados a O-Ren e, provavelmente, menos habilidosos que ela. No Vol. 2, os confrontos entre ela, Bill e Budd são menos elaborados. Facilmente subjugada por Budd, ela jamais o enfrenta diretamente, ainda que o personagem tenha sido morto pelo veneno de uma Mamba Negra - a cobra que dera origem a seu codinome no esquadrão. Já o confronto com Bill é rápido: para matá-lo o personagem usa um golpe mortal e secreto, um artifício reservado apenas para ele. Deste modo, o grande confronto de Kill Bill Vol. 2 não é com nenhum deles, e sim com Elle Driver, com quem livremente pode mostrar sua fúria e sua força.

Em relação aos confrontos entre a protagonista e os personagens masculinos da trama, um contraste se estabelece na disputa da protagonista com Pai Mei, da qual dependia sua aceitação como aprendiz pelo mestre em artes marciais. Neste caso, ainda que seja necessário mostrar sua persistência e habilidade, a última não pode ser maior que a do mestre. Assim, espera-se que ela perca a disputa, de modo a que o treinamento se justifique na narrativa. Neste caso, então, o confronto com Pai Mei pode ser mostrado sem que se questione sua capacidade de levar a termo sua vingança. A digressão que a relaciona a Pai Mei serve, assim, a outros propósitos: imprime uma certa racionalidade à sequência em que escapa da sepultura e justifica o conhecimento da técnica utilizada para assassinar Bill, além de fornecer mais um elemento para o confronto entre ela e Elle Driver.

Na relação entre homens e mulheres, Kill Bill nos apresenta um mundo em que elas habilmente se apoderam de objetos pontiagudos para penetrar outros corpos, enquanto os homens munidos por armas de fogo se apresentam torpes ou manipuladores. Embora apresentado como um homem fraco e alcoólatra, Budd revela que sua principal arma é a dissimulação. Da mesma maneira Bill, o principal personagem masculino das narrativas, mostra-se poderoso pela manipulação. Tanto a dissimulação quanto a manipulação são atributos geralmente associados a personagens femininos ${ }^{16}$. Assim, a mescla de atributos de gêneros não se refere apenas aos personagens femininos. Neste sentido, a caracterização de gênero não aparece ameaçada por uma feminilização de personagens masculinos ou a masculinização de personagens masculinos.

16 Como acontece em Femme Fatale (Brian De Palma, 2002) em relação a Laure. 
Apesar disso, apenas os corpos das mulheres oferecem-se aos olhos, ora em vestimentas ajustadas ao contorno de suas silhuetas, ora se aproveitando de fetiches masculinos:
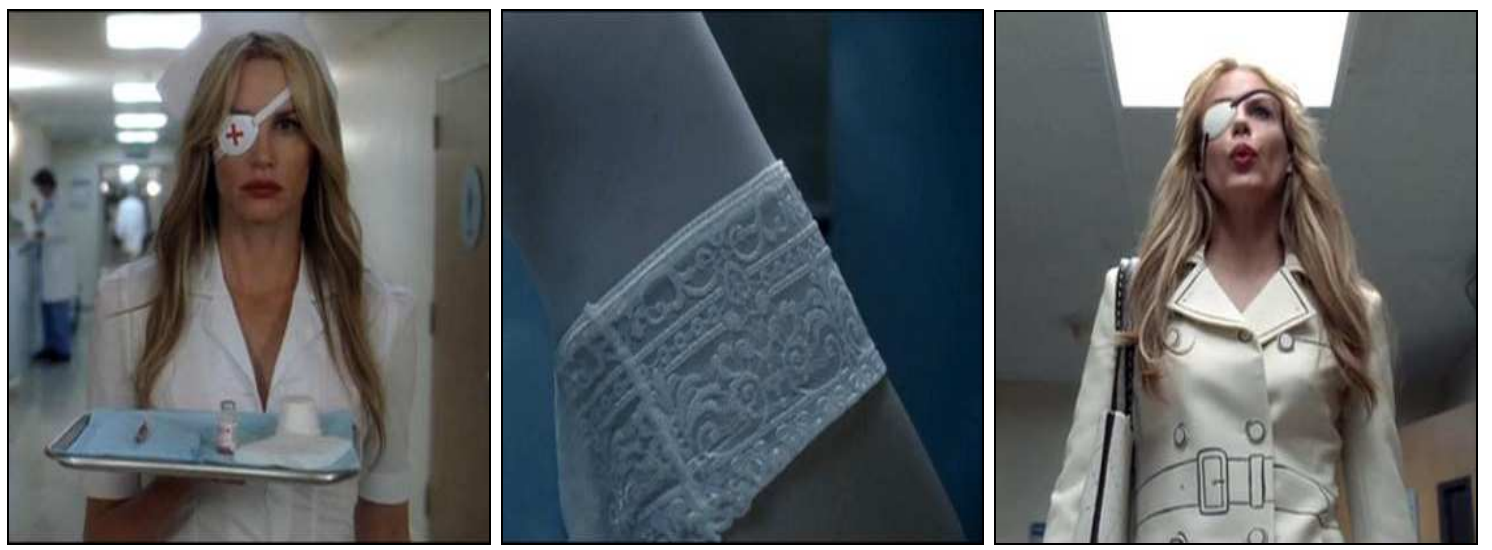

Elle Driver: exibe seus longos cabelos estrategicamente posicionados ao lado dos seios. Para passar-se por enfermeira, veste meias sete-oitavos.

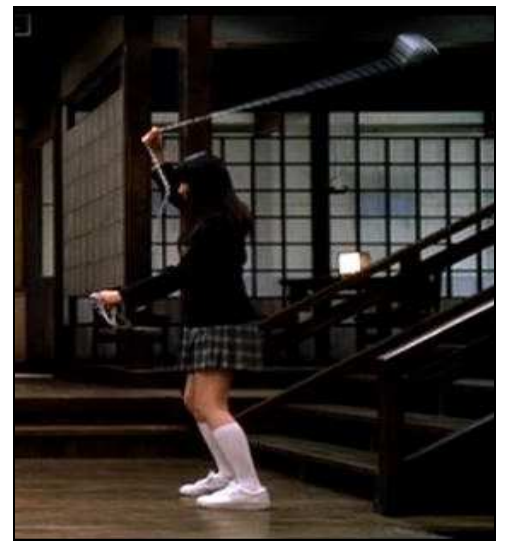

Gogo Yubari: a ninfeta vestida de colegial.

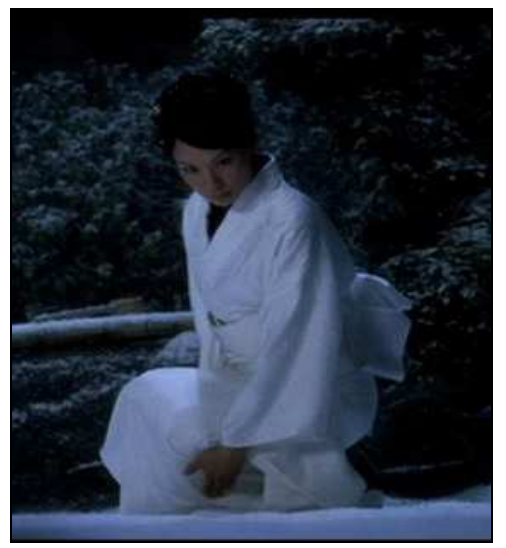

O-Ren: morre vestida como gueixa, símbolo de submissão feminina.

As relações entre as assassinas do antigo esquadrão de Bill são permeadas por grande rivalidade. Vernita Green, O-Ren Ishii e Elle Driver disputam com a protagonista a predileção de Bill e o lugar de mulher mais letal, questionando as habilidades umas das outras. Entre elas, não parece haver outro modo de relacionamento possível. As únicas mulheres que não se desprezam são O-Ren Ishii e Sofie Fatale, mas porque desempenham papéis diferentes. Sofie não é uma assassina, ORen é. Sofie é construída numa chave diferente das outras mulheres da trama, ainda que integrasse o antigo esquadrão de Bill. $\mathrm{O}$ fato de atender ao telefone durante o massacre em El Paso, além de marcar seu desprezo pela protagonista, mostra também seu distanciamento em relação às ações dos outros membros do esquadrão. A violência 
parece ser para ela parte dos negócios nos quais se envolve e o poder que dela advém, o objeto de sua lealdade. Por isso Sofie não rivaliza com O-Ren. Neste caso, é o fato de ocuparem lugares diferentes em relação à violência que lhes garante a cooperação. Uma vez que no mundo proposto pela narrativa impera a lei da(o) que se mostra mais capaz de matar, o lugar de Sofie como subalterna torna-se indiscutível. A caracterização de Sofie Fatale é bastante interessante. Inegavelmente, seu sobrenome remete à figura femme fatale. Apesar da inegável beleza, seu corpo aparece frequentemente coberto por longas túnicas. Fútil, sem mistérios, de uma sexualidade apagada, Sofie Fatale evidentemente coloca o arquétipo da femme fatale em segundo plano.

Em Kill Bill a violência aparece, desta maneira, plenamente associada ao poder e à morte. A violência garante que os personagens manipulem, convençam e imponham sua vontade sobre os outros, mas também que decidam sobre quem sobrevive e quem deve morrer. A violência se expressa, nestas narrativas, por meio dos corpos de seus personagens mais que da posse de qualquer arma. As armas de diversos tipos aparecem como instrumentos, como acessórios da violência, mas a sua ausência não impede que esta se realize. Por um lado, os corpos convertem-se em armas, apropriando-se de quaisquer objetos que possam ajudá-los a realizar a violência. Por outro, o corpo inerte ou rendido aparece como aquele incapaz de realizá-la. Apesar disso, uma arma se destaca na narrativa como objeto-fetiche: a espada de Hattori Hanzo aparece associada a um poder letal ímpar, sua posse impõe respeito e desejo. Entre os assassinos, a espada torna-se objeto de disputa e sua posse torna-se prova da vitória.

Em relação a sua protagonista, os filmes propõem um outro desafio ao espectador. Meu argumento é que sua identidade é construída e revelada através de detalhes que se apresentam como peças de um mosaico a ser montado durante os filmes pelo espectador, e que decorrem da relação entre o que é mostrado através das imagens e do que é proposto através do enredo e das ações dos personagens envolvidos na trama.

Sua identidade é dada a conhecer já no primeiro diálogo Kill Bill Vol. 1: Kiddo. O sobrenome, no entanto, engana o espectador que, despercebido, acredita que ela tenha sido chamada de garotinha, de pirralha. "Silly rabbit, trix ${ }^{17}$ are for kids" - o coelho, no caso, são todos os espectadores. O jogo de nomes e denominações que fazem parte da trama de Kill Bil desperta a atenção aos detalhes que caracterizam Kiddo, especialmente

17 Diminutivo de Beatrix, soa também como "tricks", truques, artimanhas. Ainda que o nome Beatrix possa ser considerado como uma referência à figura da domintrix, nada em sua caracterização colabora para uma interpretação neste sentido. 
no primeiro filme. Sua beleza é repetidamente declarada pelos personagens masculinos da trama. Numa atmosfera de falso mistério, é revelado que essa mulher é considerada bela por aqueles que a rodeiam - um anjo, como a chamaram algumas vezes. Na primeira delas, o xerife que atende à ocorrência do massacre em El Paso apresenta o que, em sua aparência, lhe faz parecer um: sua beleza ornamentada pelos cabelos cor de feno e os grandes olhos. Em retribuição, o xerife recebe a cuspida involuntária do personagem já em coma. A qualificação torna-se completamente sem propósito ao se pensar que, dado o estado em que fora encontrada, pouca ou nenhuma beleza poderia ser reconhecida em sua figura.

Os elogios à sua figura, na forma de diálogos, parecem ser, em princípio, uma estratégia utilizada para diminuir o impacto causado pela sequência inicial, afinal, de que maneira uma imagem tão grotesca poderia despertar a simpatia do espectador? No entanto, a estratégia não funciona, uma vez que o uso reiterado de flashback(s) durante Kill Bill Vol. 1, ainda que não sejam repetidos os planos de seu rosto e corpo feridos, remetem o espectador para o massacre de El Paso e para a imagem da ofensa. Além disso, as ações da protagonista durante a trama - a fúria e retidão que emanam de seu corpo, ainda que emoldurado por figurinos que valorizam sua silhueta - não colaboram para que seja vista como um anjo ou uma bela mulher.

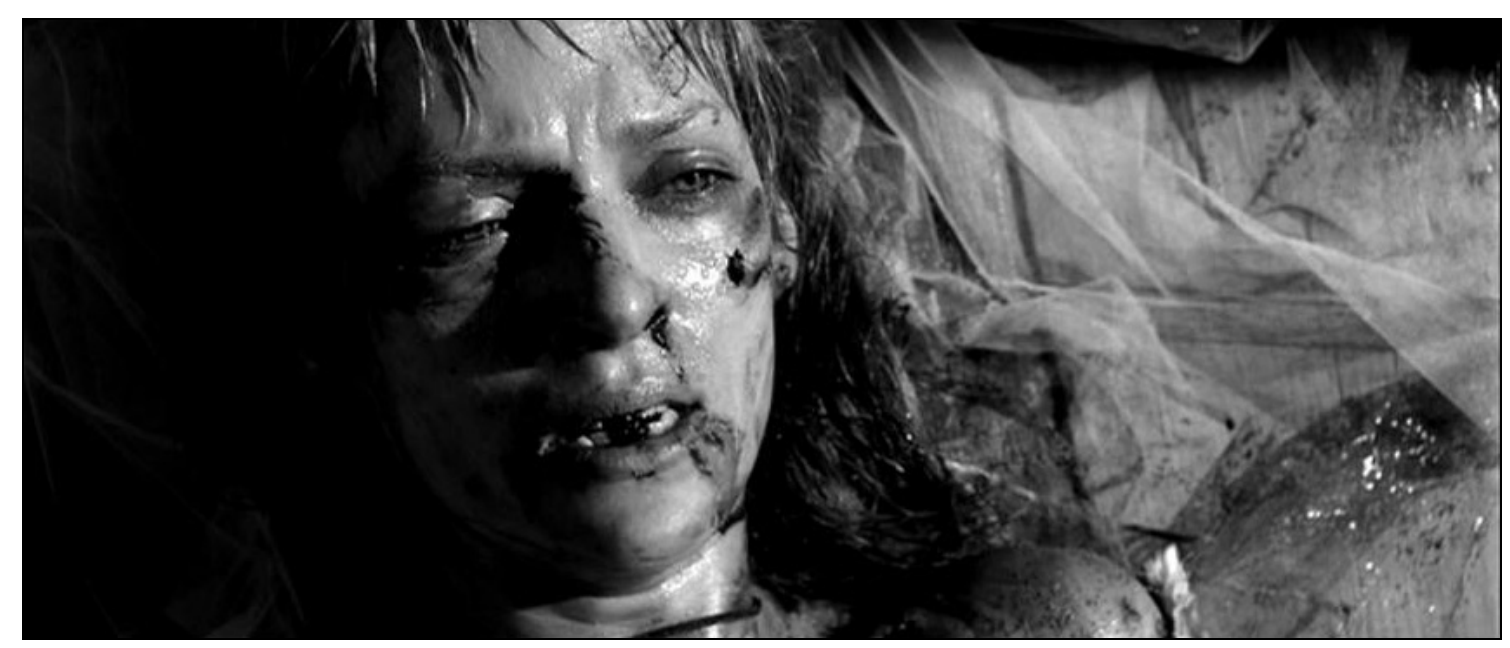

Incapaz de perdoar, esta mulher decide assassinar aqueles que a agrediram. Segue à risca o plano que traçou, reprimindo qualquer sentimento de misericórdia e compaixão, e por isso é uma guerreira ${ }^{18}$. Seu nome soa como um palavrão na presença

18 De acordo com a caracterização apresentada por Hattori Hanzo em Kill Bill Vol. 1. 
daqueles que a desprezam ${ }^{19}$, enquanto sonoros bitch são trocados sem pudor entre os personagens da trama. Talvez porque Beatrix, ao contrário do significado de seu nome, não traga alegria. O nome escolhido por ela após fugir de Bill, Arlene Machiavelli ${ }^{20}$, descartado imediatamente como falso pelo policial que a encontrara na capela em El Paso, acaba dizendo mais a seu respeito. O nome demonstra seu comprometimento com a maternidade, já que para ser mãe o personagem abandona o estilo de vida que levava. Por outro lado, demonstra que para alcançar um objetivo ela é capaz de planejar e utilizar-se de qualquer meio, mesmo que para alcançar a fortuna seja necessário submeter-se a um sacrifício pessoal ou aniquilar todos os seus inimigos.

A ação e as imagens refutam, em grande medida, a maneira como ela é tratada. Bitch soa agressivo, não por sua conotação pejorativa, mas porque o espectador identifica-se com o personagem - afinal, conhece-se a razão pela qual mata, razão esta que está completamente justificada na narrativa do primeiro filme. A ideia da retaliação opera dos dois "volumes" de Kill Bill com toda sua força, constituindo-se no eixo central da história.

Grande parte da simpatia para com ela advém, em contrapartida, do fato de que o passado desta mulher não existe nos filmes. Sabe-se que ela matava por dinheiro, mas ela não é vista fazê-lo. Supõe-se que algo aconteceu entre ela e Bill que provocara sua ira. Se o Vol. 2 mostra o que foi, isso ocorre em um momento em que as principais características de seu personagem já estão assimiladas pelo público. E por mais que se diga que o segundo filme conte o que o primeiro não contou $^{21}$, ela não existe na narrativa senão para matar Bill e o que sabe-se dela diz respeito apenas a sua missão na tela. Se ela se chama Beatrix Kiddo ou Arlene Machiavelli pouco importa - afinal, quem garante que ela sempre foi Kiddo? Assim, ver Uma Thurman usando mariachiquinhas e respondendo a chamada da professora rodeada por crianças, declarando ao público ser mesmo Beatrix Kiddo desde uma infância impossível de se ver, diz muito mais a respeito de um anseio do espectador em atribuir-lhe uma identidade única e singular que de uma necessidade da trama.

19 Nos dois filmes, apenas Bill e Elle Driver pronunciam seu nome sem que o mesmo seja omitido por um beep - recurso frequentemente utilizado em televisão para omitir palavras de baixo calão. Em Kill Bill Vol. 2, Elle o faz logo após qualificá-la como a pessoa mais letal do mundo, admitindo que a admirava mesmo odiando-a.

20 Arlene significa promessa, compromisso. Machiavelli faz referência a Nicolau Maquiavel e, possivelmente, ao conteúdo de sua obra, $O$ Príncipe.

21 Quentin Tarantino afirma no making-of de Kill Bill Vol. 2: "O Vol. 1 tem as questões, o 2 tem as respostas". 

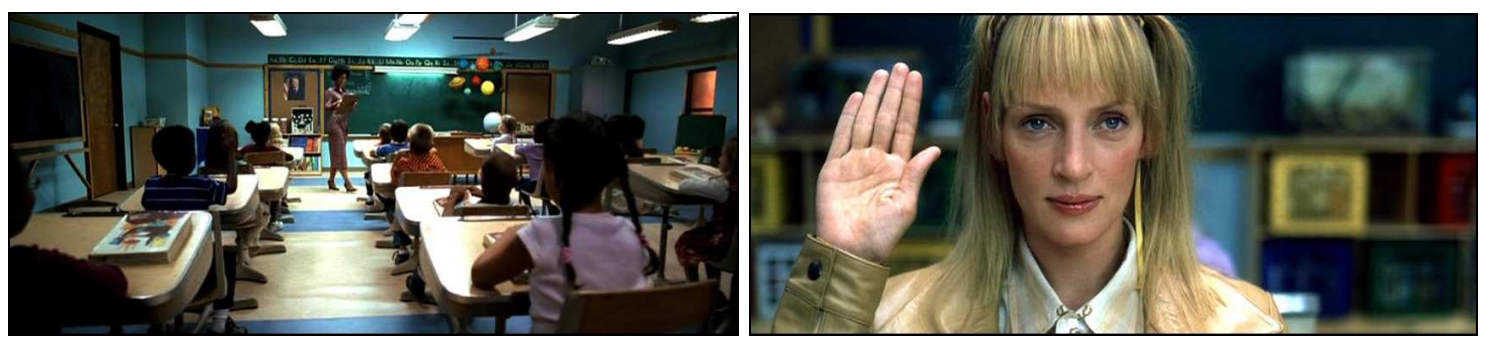

Talvez por isso o personagem tenha ficado mais conhecido como A Noiva, apesar de ser chamado assim apenas uma vez, no primeiro filme, por causa do vestido que usava ao ser encontrado pelos policiais na capela de El Paso ${ }^{22}$. Aqui, assim como acontece em Lara Croft: Tomb Raider, é o vestido que diz quem ela é e, principalmente, que lugar social deveria ocupar. Seu vestido é, portanto, marca de uma certa feminilidade: a da pureza e a da entrega. Mas contraditoriamente, já sabe-se que essa não é uma noiva qualquer. Sua fuga e seu casamento aparecem vinculados ao desejo de proporcionar ao bebê um estilo de vida que é o oposto daquele que levava, um desejo que se sobrepõe também à relação que ela mantinha com o pai da criança. Assim, a maternidade e sua atividade profissional aparecem em conflito, mas em nenhum momento ela se mostra arrependida de haver sido uma assassina profissional. O casamento com outro homem aparece, então, como via de acesso a um novo estilo de vida, da mesma forma que ser uma assassina profissional garantia a ela relacionar-se com Bill ${ }^{23}$. A escolha de Kiddo por diferentes estilos de vida está vinculada, portanto, às suas relações afetivas. E no seu caso, o amor e a carreira aparecem como violência, enquanto a maternidade aparece como redenção.

Se é possível traçar um perfil de Kiddo como guerreira, este perfil perpassa não apenas sua relação com a violência, mas também com a maternidade. Violência e maternidade aparecem em conflito nas narrativas, não apenas no que se refere aos estilos de vida a que estão associados, mas fundamentalmente no modo como são construídas. Kiddo tem sua existência na narrativa estritamente vinculada à existência de Bill. No entanto, a maneira como Bill lhe atribui identidade é diferente daquela que

22 É também assim que o personagem aparece na publicidade a respeito dos filmes, o que sem dúvida ajuda a identificá-la como A Noiva e não como Kiddo. E por mais que o personagem tenha sido originalmente criado como tal por Tarantino e Thurman, a escolha por essa denominação aponta também para o fato de que o personagem não necessariamente precisa de um nome próprio nas narrativas, ele pode ser quem quer que seja.

23 Kiddo declara no fim do Vol. 2 que, apesar de sua competência e do prazer que sentia em matar, era assassina por causa de Bill. 
os filmes propõem. Para Bill, a violência é parte da personalidade - dele, de Kiddo e ao fim, da própria criança - e, portanto, é da ordem do irracional. Kiddo mostra o oposto. A violência nela aparece como um atributo adquirido, como resultado de treino e de esforço. Enquanto vê-se Bill afirmar que Kiddo é naturalmente uma assassina, ela é vista treinar e planejar. Assim, enquanto a violência é naturalizada pela história, é refutada pelas imagens mostradas pelas narrativas.

Algo muito diferente ocorre quando Kiddo se dá conta de que está grávida. Ela se torna "mãe" imediatamente, como por um passe de mágica. E novamente ao encontro das expectativas de Bill, que supõe que a maternidade em Kiddo exigiria dela todo um esforço de adequação inútil, não é isso o que se vê. Enquanto a história insiste na proposição de que Kiddo é naturalmente uma assassina, as narrativas mostram como ela se tornou uma. Quando ela descobre estar grávida, ela se torna "mãe" sem nenhuma mediação, incapaz de matar, ocupada com a nova vida dentro dela ${ }^{24}$. No entanto, uma vez que confessa a Bill, sob efeito do soro da verdade, que não acreditava que sua mudança de estilo de vida daria certo, percebe-se que também essa maternidade apresenta um forte conteúdo de violência para Kiddo. A naturalização da maternidade, tal qual proposta pelas narrativas, traz este conteúdo à tona apenas nesta sequência, para então voltar a ignorá-la na sequência final. Isto acontece porque, diferente do que acontece com Lara Croft, cuja sensualidade exacerbada é a âncora que faz com que o personagem seja reconhecido como um personagem feminino, no caso de Kiddo, é a maternidade que toma este lugar.

Alheia ao fato de que sua filha sobrevivera ao massacre, Kiddo concebe sua vingança como uma missão. Sua recompensa não é apenas conseguir matar a todos que planejara, mas sim encontrar a filha no final do segundo filme. Kiddo é, portanto, uma guerreira que luta, mesmo sem saber, pela maternidade. Para ela, a maternidade se converte em dádiva e em destino - já que ela ignora que sua filha sobrevivera na maior parte da trama -, mas estranhamente, estes só se realizam por meio da violência.

E curiosamente, o exercício da maternidade se mostra mediada pela imagem ${ }^{25}$.

24 Da mesma maneira que a protagonista de Assassina por natureza (The Job, Kenny Golde, 2003), CJ March: ao saber que está grávida decide abandonar a profissão, mas é pressionada para terminar seu último trabalho, para o que se mostra completamente incapaz.

25 Em Lara Croft Tomb Raider: A Origem da Vida, a imagem volta a mediar as relações de parentalidade na sequência em que a protagonista interrompe o café-da-manhã de um família em Hong Kong para pedir a televisão emprestada para se comunicar com Hillary e Bryce. Na sequência, o pai está à mesa com os dois filhos, assistindo um desenho animado em que Bob Esponja conversa com Patrick ao telefone. Em seguida, a mãe aparece na cozinha. O desenho animado antecipa, assim, 
Nos dois momentos em que Kiddo aparece dedicando-se à filha, elas assistem juntas um filme de kung fu e um desenho animado. O filme de kung fu, assistido na casa de Bill como parte da rotina da criança na hora de dormir, apresenta-se como metáfora do tipo de educação dada por Bill e do estilo de vida que Kiddo recusara ao abandonar o pai da criança. Já o desenho animado, ao qual vê-se Kiddo juntar-se a sua filha para assistir no quarto de hotel em que o segundo filme termina, se refere ao estilo de vida que ela escolhera para as duas. A diferença entre os dois não está na ausência de violência, mas sim na sua dissimulação. Se o filme de kung fu se inicia pela narração de decapitações e outras agressões - as quais o espectador somente pode ouvir -, o discurso do desenho animado aborda os motivos de se defender uma gralha, para, finalmente mostrá-la acertando a cabeça do personagem que a defendera. Deste modo, a narrativa não nega a proposição de Bill de que a violência seja parte da natureza de seus personagens: Kiddo e a criança se divertem com a atitude da gralha. Contudo, se Kiddo conseguirá de fato proporcionar à filha um outro estilo de vida é uma questão que sobrepassa às possibilidades das histórias.

Kill Bill Vol. 1 e Kill Bill Vol. 2 apresentam a história da vingança de Kiddo a partir de estratégias bastante distintas. Os filmes propõem um conceito de guerreira que se apresenta plenamente justificado nas narrativas, abrindo a possibilidade de que a protagonista se realize através da violência sem qualquer comoção ou remorso, mas também sem se converter em personificação da justiça. No universo construído pelas narrativas de Kill Bill, a violência sediada no corpo se apresenta como um espetáculo de contradições, assim como a maternidade. O corpo de Kiddo, morada da violência e da maternidade, apresenta os limites da construção da guerreira pelo cinema. Se por um lado, a maternidade faz com que Kiddo possa ser reconhecida como mulher, ela também expõe a força do imaginário da mãe que zela, não mata. A maneira absolutamente imaculada com que assassina Bill, não apresenta, assim, qualquer ameaça a este imaginário. Talvez por isso Kiddo receba sua recompensa, tornando-se uma assassina digna de um final feliz.

as intenções de Lara ao invadir o barco onde mora a família. 


\section{Notas FINAIS}

Argumentou-se aqui que a especificidade da figura da mulher violenta está na sua estranheza. Impossível passar por ela sem se perguntar: que mulher é essa? Pois é, a beleza da figura da mulher violenta - sim, há uma beleza nela - é que esta mulher não é uma só. Ela simboliza o lugar da diferença, da alteridade, do outro. Não o outro do masculino, mas o outro do feminino. Um outro que pode tanto parecer valorizado, quanto desvalorizado. Que tanto pode ser convertido em menos, em abjeto, quanto em sujeito.

Tentando cruzar a fronteira entre o sujeito e o abjeto, a figura da guerreira parece tentar se equilibrar numa corda bamba. Ela necessita algo em que se agarrar, pois qualquer movimento em falso, o tombo para o outro lado da fronteira do sujeito é certo. Ela se agarra como pode, não no que a diferencia, mas naquilo que a faz parecer reconhecível, nos elementos de seu próprio outro, o feminino. Ao mesmo tempo, ela brinca com aquela figura que nem tenta cruzar a fronteira, que tem ali seus pés fincados, como raízes profundas, no terreno do abjeto. É com essa figura que ela não quer mais se identificar. No trajeto percorrido aqui, essa figura tem o nome de Thana.

Thana simboliza, em primeiro lugar, o aspecto violento da materialização do sexo. Forjada como um personagem de aspecto angelical, doce, calado e reservado, imagem de boa menina, Thana torna-se mulher sendo violentada e violentando. Como o abjeto que não é objeto de discurso, nega-se também a Thana a possibilidade de ser sujeito dele. Contudo, Thana ainda assim se comunica, mas o que ela expressa é ininteligível, pertence ao domínio da loucura, pois quanto mais se apropria de uma imagem feminina, mais distante ela se torna de um feminino viável, sob controle. Neste sentido, Thana simboliza, em segundo lugar, a impossibilidade da associação entre violência e feminino, a descaracterização da identidade feminina pela presença da violência.

Não por acaso Thana é um personagem metropolitano de um estilo de vida simples, bem como não é aleatório que esteja inserido no seio da cadeia produtiva de uma indústria têxtil. Sedução e Vingança é um filme que continua dialogando com o problema do surgimento da Nova Mulher - desdobramento da Revolução Industrial e da urbanização da vida social - e, neste sentido, em seus aspectos mais gerais, isto é o que todos os filmes interpretados aqui fazem. No que tem de mais particular, ele reelabora 
os perigos da vida urbana não apenas no que concerne o corpo feminino, mas, também, no que concerne a possibilidade de uma rematerialização identitária, do pavor do apagamento das diferenças entre os sexos pela masculinização da mulher. A masculinização da mulher não se constitui, então, como uma ameaça aterradora simplesmente porque implica na possibilidade imaginária de uma redistribuição de poder entre os gêneros - que nada mais faria que reconfigurar uma mesma estrutura de dominação -, mas porque coloca em questão a possibilidade de feminilização do masculino, da morte do gênero, este sim o grande tabu, o desconhecido, a loucura, o Alien. Não é de estranhar, portanto, o vigor com que Thana tem suas raízes fincadas do lado da fronteira do abjeto. O cinema - esta entidade também imaginária que, por vezes, no discurso, parece ser sujeito sem o ser - tardou em perceber, principalmente no que tange a violência, que o sexo continua se materializando, apesar da vida urbana e da atividade feminina. Como discute Gilles Lipovestky, a constituição da mulher como sujeito não implica numa extinção do sexo, mas numa reorganização da vida social que aponta para transformações, mas, também, para permanências ${ }^{1}$.

Assim, quatro outros personagens observam Thana da linha da fronteira. $\mathrm{O}$ primeiro deles é Nikita. Um dos poucos personagens da década de 1990 que emerge indócil sem qualquer justificativa, Nikita mostra como se dá o processo de docilização do corpo feminino a partir de uma situação limite. Este processo introjeta uma característica física - sua aparente fragilidade - instaurando um conflito identitário que só pode ser superado se os laços com uma feminilidade tradicional - que são estabelecidos enquanto o espectador a vê sofrer - forem rompidos. Apesar de fazê-lo, ao cruzar a fronteira do sujeito, Nikita desaparece de cena. Permanece na memória do espectador o incômodo de percebê-la como mulher por meio daquela fragilidade introjetada e irritante, que faz não só com que ela derrame lágrimas incontáveis, mas também com que faça o que lhe mandam, que se submeta. Nikita, ao autonomizar-se, não realiza apenas uma fantasia de empoderamento feminino, mas uma fantasia de empoderamento de qualquer sujeito, que sonha com a possibilidade da deserção, da insubmissão. É exatamente por isso que ela cruza a fronteira, tornando-se, inegavelmente, sujeito de sua própria experiência, pois se habilita a governar a si mesma. Nikita é, neste sentido, um personagem que simboliza o difícil processo de auto-reconhecimento de mulher como sujeito. Sobre isso falam seus constantes

\footnotetext{
${ }^{1}$ Cf. Lipovestky, Gilles, La tercera mujer, op. cit., 1999, pp. 222-238.
} 
renascimentos, seus insistentes retornos ao que lhe é conhecido, incapazes de apaziguar as contradições que emergem da fabricação de uma identidade feminina que mescla violência e fragilidade.

São justamente as diferentes dimensões que compõem a fragilidade de Nikita que a fazem parecer uma mulher estranha, outra. A primeira dimensão, a aparente fragilidade do corpo, faz com que ela seja, inicialmente, lida numa chave tradicional: o corpo frágil não pode ferir, não é um corpo perigoso. Revelado o que se esconde por detrás da aparência, o que acontece, então, é ainda mais perturbador, pois a fragilidade inculcada, sua segunda dimensão, revela todo seu caráter construtivo, deixa de parecer um atributo "natural" deste feminino. Deste modo, a fragilidade em Nikita tanto a aproxima do feminino, quanto a distancia dele, descortinando o modelo que o rege. Sua fragilidade é, portanto, dúbia, pois, com a mesma força que a torna inteligível, torna-a irreconhecível. Fica claro que seguir o modelo de feminilidade tradicional é $o$ inviável. Por isso, Nikita viabiliza-se na autonomia.

O segundo personagem situado na fronteira entre sujeito e abjeto é Lara Croft. Do meio da corda bamba, Lara olha Thana de frente, com suas duas pistolas nas mãos. Lara é um personagem interessante porque é, sob o meu ponto de vista, aquele por meio do qual a guerreira supera seu elemento fálico. Entretanto, dentre todos os personagens interpretados durante este percurso, Lara é, também, o personagem mais ambíguo. Os elementos que compõem o lado dominador de sua caracterização ameaçam sua identificação como sujeito todo o tempo. Tomá-la como dominatrix, como mera atualização da figura da mulher fálica, é uma possibilidade que não ouso contestar. Será o outro lado de sua caracterização, aquele que pode ser considerado como o elemento mais tradicional da composição de seu personagem, que garante que Lara apareça como um outro-feminino viável. Neste sentido, os elementos femininos nos quais ela se agarra para cruzar a fronteira do abjeto são a sedução e o exercício da coqueteria.

Já Beatrix Kiddo é o personagem que, na fronteira, olha Thana mais de longe. A razão para que isso aconteça é bastante simples. Sua figura está absolutamente ancorada na maternidade. Isto não significa que o outro-feminino que dela apareça não tenha suas ambiguidades, mas novamente, a maternidade converte-se no fundamento primeiro da inteligibilidade do personagem. A questão da maternidade é tão central que se apresenta como o principal motivo para que Kiddo, primeiro, desista e, depois, volte a matar. No momento da descoberta da vida que se renova, a revelação de sua gravidez impede até que ela seja assassinada por outra mulher que, curiosamente, não só desiste de cumprir 
sua missão, como a parabeniza. A maternidade, assim, tanto é o que garante que ela torne-se sujeito perante o espectador, como o que apresenta um dos grandes limites ao imaginário da possibilidade da violência feminina neste cinema.

A questão da maternidade em Kiddo é central também para se perceber que o aparecimento de outros-femininos, no cinema, por meio da inclusão da violência como atributo deste sexo, não implica na possibilidade do apagamento ou da superação das distinções de gênero. Tais distinções, ao contrário, reinscrevem-se e reelaboram-se pela íntima relação que estes personagens têm com o feminino "tradicional". Dessa forma, a associação da violência à figura feminina não significa, em última instância, que os atributos de gênero estão perdendo força, mas que as normas de fabricação do sexo flexibilizam-se em algumas direções, enquanto em outras permanecem indubitavelmente consolidadas. No que concerne a este aspecto, a figura da guerreira também reitera certas normas que materializam o sexo feminino. A maternidade, neste sentido, permanece como uma pedra fundamental da identidade feminina, um tabu que nem a associação da violência à figura feminina pode abalar. Contudo, o que se tem como resultado é que, estranhamente, mas não por acaso, a força desta figura tida por tantos como transgressora advém exatamente dos elementos mais tradicionais das normas de materialização do sexo. Na figura da guerreira, aquilo que garante a permanência é também o que gera a transformação, pois

no curso de sua reiteração, o sexo é tanto produzido quanto desestabilizado. Como um efeito sedimentado de uma prática reiterativa e ritual, o sexo adquire seu efeito naturalizado, e, apesar disso, é também por causa dessa reiteração que lacunas e fissuras são abertas como instabilidades constitutivas de tais construções, como aquilo que escapa ou excede a norma, como aquilo que não pode ser completamente definido ou fixado pelo seu trabalho repetitivo. Esta instabilidade é a possibilidade desconstitutiva no interior do mesmo processo de repetição, o poder que desfaz os efeitos pelos quais o "sexo" é estabilizado, a possibilidade de colocar a consolidação das normas do "sexo" em um crise potencialmente produtiva $^{2}$.

Por fim, Erica encara Thana mais uma vez e o que vê é o estereótipo da

Butler, Judith, Bodies that matter, op. cit, 1993, p. 10; grifos do autor. 
violência feminina a sua frente. Erica, mais que qualquer um destes personagens simboliza a fronteira entre sujeito e abjeto, pois agoniza, renova-se, estranha-se, experimenta-se até, por fim, aceitar-se e ser aceita como um sujeito-outro, como resultado de um processo temporal e identitário em que não há retorno, mas que nem por isso se dá por encerrado. De volta ao espaço primordial daquela Nova Mulher, ela cruza o portão que simboliza o estranhamento causado por sua figura e segue adiante, deixando Thana e o seu estereótipo para trás. 


\section{BIBLIOGRAFIA}

ABRAMO, Helena Wendel. Cenas Juvenis - Punks e Darks no Espetáculo Urbano. São Paulo: Scritta; Anpocs, 1994.

"Alien". In: Box Office Mojo, disponível em: http://www.boxofficemojo.com/movies/?id=alien.htm, acessado em 30/08/2010.

ALTMAN, Andrew. "Making Sense of Sexual Harassment Law". In: Philosophy and Public Affairs, Vol. 25, $\mathrm{N}^{\circ}$ 1, 1996, pp. 36-64.

ANDERSON, Aaron. "Mindful violence: the visibility of power and inner life in Kill Bill". In: Jump Cut: A Review of Contemporary Media, 47, 2005; disponível via URL em: http://www.ejumpcut.org/archive/jc47.2005/KillBill/ text.html, acessado em 24/04/2006.

ARNHEIM, Rudolf. A arte do cinema. Lisboa: Edições 70, s/d.

ARTHUR, William. An Etymological Dictionary of Family and Christian Names. Nova Iorque: Sheldon, Blakeman \& Co., 1857.

AUMONT, Jacques [et al]. A estética do filme. Campinas: Papirus, 1995.

BALÁZS, Bela. "A face do homem”. In: Xavier, Ismail (org.). A experiência do cinema: antologia. Rio de Janeiro: Graal: Embrafilmes, 1983, pp. 92-96.

BARTHES, Roland. "A mensagem fotográfica". In: O óbvio e o obtuso: ensaios críticos III. Rio de Janeiro: Nova Fronteira, 1990, pp. 11-25.

BAZIN, André. "A evolução da linguagem cinematográfica". In: O Cinema - Ensaios. São Paulo: Brasiliense, 1991a, pp. 66-81. . "Ontologia da imagem fotográfica". In: . O Cinema - Ensaios. São Paulo: Brasiliense, 1991b, pp. 19-26.

BBC News. 1997: Hong Kong handed over to Chinese control. Disponível via URL em: http://news.bbc.co.uk/onthisday/hi/dates/stories/july/1/newsid_2656000/2656973.stm; acessado em 15/08/2010.

BERGER, John. Modos de Ver. Rio de Janeiro: Rocco, 1999. . "Why look at animals?". In: . About looking. Nova Iorque: Vintage International, 1991, pp. 3-28.

BORDWELL, David. "O cinema clássico hollywoodiano: normas e princípios narrativos". In: Ramos, Fernão Pessoa (org.). Teoria contemporânea do cinema, Volume II: Documentário e narratividade ficcional. São Paulo: Editora Senac São Paulo, 2005, pp. 277-301.

BROWN, Jeffrey A. "Gender, Sexuality and Toughness: The Bad Girls of Action Film and Comic Books". In: Innes, Sherrie A. Action chicks: new images of tough women in popular culture. Nova Iorque: Palgrave Macmillan, 2004, pp. 47-74. 
BRUNI, José Carlos. “A água e a vida”. In: Tempo Social - Revista de Sociologia da USP, São Paulo, 5 (1-2), 1993, pp. 53-65.

BUTLER, Judith. Bodies that matter: on the discursive limits of "sex". Nova Iorque, Londres: Routledge, 1993.

. Gender Trouble. Feminism and the Subversion of Identity. Nova Iorque, Londres: Routledge, 2007.

BYARS, Jackie. All that Hollywood Allows - Re-reading Gender in 1950s Melodrama. Londres: Routledge, 1991.

CARRIÈRE, Jean-Claude. A linguagem secreta do cinema. Rio de Janeiro: Nova Fronteira, 1995.

CHAUI, Marilena. Simulacro e poder: uma análise da mídia. São Paulo: Editora Fundação Perseu Abramo, 2006.

CHRISTENSEN, Terry; HASS, Peter J. Projecting Politics: Political Messages in American Film. Armonk: M.E. Sharpe, 2005.

CLARK, Randall. At a Theater or Drive-In Near You: The History, Culture and Politics of the American Exploitation Film. Nova Iorque: Garland Pub., 1995.

CLOVER, Carol J. Men, women, and chain saws: gender in the modern horror film. Princeton, NJ: Princeton University Press, 1992.

COSTA, T. et al. "Naturalização e medicalização do corpo feminino: o controle social por meio da reprodução”. In: Interface - Comunic., Saúde, Educ., Vol. 10, № 20, 2006, pp.363-380.

“cradle". In: Merriam-Webster Online Dictionary, 2010, disponível via URL em: http://www.merriam-webster.com/dictionary/cradle; acessado em 12/04/2010.

DURKHEIM, Émile. A Divisão Social do Trabalho. São Paulo: Martins Fontes, 1999. O Suicídio. São Paulo: Martins Fontes, 2000.

ECO, Umberto. Apocalípticos e integrados. São Paulo: Perspectiva, 1971.

EISENSTEIN, Sergei. "Novos problemas da forma cinematográfica”. In: Xavier, Ismail (org.). A experiência do cinema: antologia. Rio de Janeiro: Graal: Embrafilmes, 1983, pp. 216-243. . O sentido do filme. Rio de Janeiro: Jorge Zahar Editor, 1990.

ELAM, Caroline [et. al.]. "The low countries and Britain”. In: Fletcher, Sir Banister; Cruickshank, Dan (ed.) A History of Architecture. Oxford: Architectural Press, 1996, pp. 999-1064.

ELIAS, Norbert. "A individualização no processo social". In: . A sociedade dos indivíduos. Rio de Janeiro; Jorge Zahar Editor, 1994, pp. 102-125. . A sociedade de corte: investigação sobre a sociologia da realeza e da aristocracia de corte. Rio de Janeiro: Jorge Zahar Ed., 2001. . Os alemães: a luta pelo poder e a evolução do habitus nos séculos XIX e XX. Rio de Janeiro: Jorge Zahar Ed., 1997. 
ENCYCLOPEDIA OF EVERYDAY LAW. Sexual Harassment. Disponível via URL: http://www.enotes.com/everyday-law-encyclopedia/sexual-harassment

(Sexual_Harassment_325522.pdf); acessado em 07/06/2009.

ÉSQUILO. Prometeu acorrentado. São Paulo: Abril Cultural, 1980.

FAIRBANK, John King. "Frontier unrest and the opening of China". In: FAIRBANK, John King; GOLDMAN, Merle. China: a new history. Cambridge, MA: Belknap Press of Harvard University Press, 2006, pp. 187-205.

FERRO, Marc. Cine e Historia. Barcelona: Editorial Gustavo Gili, 1980.

FISCHER, Lucy. "Murder, She Wrote: Women Who Kill". In: Shot/Countershot - Film

Tradition and Women's Cinema. Princeton, NJ: Princeton University Press, 1989, pp. 269300.

FOUCAULT, Michel. “A Tecnologia Política dos Indivíduos”. In Ética, Sexualidade e Política. Rio de Janeiro: Forense Universitária, 2006 (Ditos e Escritos; V), pp. 301-318. . História da loucura. São Paulo: Perspectiva, 2003. . Vigiar e punir: nascimento da prisão. Petrópolis: Vozes, 1987.

FREUD, Sigmund. "O 'estranho"”. In. Obras Psicológicas Completas de Sigmund Freud: Edição Standard Brasileira. Volume XVII. Rio de Janeiro: Imago, 1969, pp. 275-314.

GARFINKEL, Harold. "Studies of the routine grounds of everyday activities". In: . Studies in Ethnomethodology. Englewood Cliffs, NJ: Prentice-Hall, 1967, pp. 35-75.

GOFFMAN, Erving. Manicômios, prisões e conventos. São Paulo: Perspectiva, 2003.

"Halloween". In: Box Office Mojo, disponível em URL em : http://www.boxofficemojo. com/movies/?id=halloween.htm, acessado em 30/08/2010.

HASKELL, Molly. From Reverence to Rape - The Treatment of Women in the Movies. Chicago/Londres: University of Chicago Press, 1987.

HESÍODO. "Works and Days". In: Homer and Hesiod. The Project Gutenberg E-book of Hesiod, The Homeric Hyms, and Homerica. Disponível em: http://www.gutenberg.org/catalog/ world/readfile?fk_files=1442129, acessado em 25/07/2010.

HILLS, Elizabeth. "From 'figurative males' to action heroines: further thoughts on active women in cinema”. In: Screen, 40 (1), 1999, pp. 38-50.

INNESS, Sherrie A. “'Boxing gloves and bustiers': new images of tough women”. In: (ed.). Action chicks: new images of tough women in popular culture. Nova Iorque: Palgrave Macmillan, 2004, pp. 1-17.

JAMESON, Fredric. Pós-Modernismo. A lógica cultural do capitalismo tardio. São Paulo: Ática, 1996.

KING, Neal; MCCAUGHEY, Martha. "What's a mean woman like you doing in a movie like 
this?". In: (eds.) Reel knockouts: violent women in the movies. Austin, TX: University of Texas Press, 2001, pp. 1-24.

LASCH, Christopher. A cultura do narcisismo. A vida americana numa era de esperanças em declínio. Rio de Janeiro: Imago, 1983.

LIPOVETSKY, Gilles. La tercera mujer. Barcelona: Editorial Anagrama, 1999.

- O império do efêmero: a moda e seu destino nas sociedades modernas. São Paulo: Companhia das Letras, 1989.

MACKINNON, Catharine A. Sexual Harassment of Working Women. New Haven: Yale University Press, 1979.

. Toward a Feminist Theory of the State. Cambridge, MA: Harvard University Press, 1989.

MAIA, Ana Cláudia Bortolozzi. Sexualidade e deficiências. São Paulo: Unesp, 2006.

MAINON, Dominique; URSINI, James. The modern amazons: warrior women on-screen. Pompton Plains, NJ: Limelight Editions, 2006, pp. xi-xxi.

MARTINS, José de Souza. A sociabilidade do homem simples: cotidiano e história na modernidade anômala. São Paulo: Hucitec, 2000.

MELLO, José Roberto. As cruzadas. São Paulo: Ática, 1989.

MENEZES, Paulo. À meia-luz: cinema e sexualidade nos anos 70. São Paulo: USP, Curso de PósGraduação em Sociologia: Ed. 34, 2001.

. A Trama das Imagens: Manifestos e Pinturas no Começo do Século XX. São Paulo: Edusp, 1997.

. “O Cinema Documental como 'Representificação': verdades e mentiras nas relações (im)possíveis entre representação, documentário, filme etnográfico, filme sociológico e conhecimento". In: NOVAES, Sylvia Caiuby [et al.] (orgs.). Escrituras da imagem. São Paulo: Fapesp: Edusp, 2004, pp. 21-45.

. "O nascimento do cinema documental e o processo não civilizador”. In: Martins, José de Souza; Eckert, Cornélia; Novaes, Sylvia Caiuby (orgs.). O imaginário e o poético nas ciências sociais. Bauru: Edusc, 2005, pp. 73-127.

MERLEAU-PONTY, Maurice. "O cinema e a nova psicologia”. In: Xavier, Ismail (org.). A experiência do cinema: antologia. Rio de Janeiro: Graal; Embrafilmes, 1983, pp. 103-117.

"modest". In: Merriam-Webster Online Dictionary, 2010, disponível via URL em: http://www.merriam-webster.com/dictionary/modest; acessado em 13/04/2010.

MORIN, Edgar. As estrelas: mito e sedução no cinema. Rio de Janeiro: José Olympio, 1989.

NERONI, Hilary. The violent woman: femininity, narrative, and violence in contemporary American cinema. Albany, NY: State University of New York Press, 2005.

NEVES, Fernando Lima das. Nas encruzilhadas do "eu" e do "nós": juventude, auto-imagem e 
interação social numa pequena cidade. São Paulo: Programa de Pós-Graduação em Sociologia, FFLCH-USP, Dissertação (Mestrado), 2006.

PRIMORATZ, Igor. "Sexual Morality: Is Consent Enough?". In: Ethical Theory and Moral Practice, Vol. 4, N 3, Cultivating Emotions, 2001, pp. 201-218.

QUINLIN, Vicky. “Sexual Harassment”. In: Agenda, N³, 1988, pp. 40-42.

QUINN, Beth A. "Sexual Harassment and Masculinity: The Power and Meaning of 'Girl Watching"'. In: Gender and Society, Vol. 16, N³, 2002, pp. 386-402.

SAÇASHIMA, Edilson Atsuo. A Questão da "Violência" no Cinema de Stanley Kubrick. Análise dos filmes Laranja Mecânica, Barry Lyndon e O Iluminado. São Paulo: Programa de PósGraduação em Sociologia, FFLCH-USP, Dissertação (Mestrado), 2007.

SCARPA, Paulo César Almeida. Transgressão, mercado e distinção: a violência extrema no cinema. Curitiba: Universidade Federal do Paraná, Dissertação (Mestrado), 2007.

SCOTT, A.O. "Packing Heat After a Coldhearted Crime". In: The New York Times, 14/09/2007. Disponível via URL: http://movies.nytimes.com/2007/09/14/movies/14brav.html; acessado em 17/06/2009.

SHOHAT, Ella; STAM, Robert. Crítica da imagem eurocêntrica. São Paulo: Cosac Naify, 2006.

SIMMEL, Georg. "O estrangeiro". In: Moraes Filho, Evaristo (org.). Georg Simmel: Sociologia. São Paulo: Ática, 1983b, pp. 182-188.

. "Psicologia do coquetismo". In: Filosofia do amor. São Paulo: Martins Fontes, 1993, pp. 93-111.

SINGER, Ben. "Female Power in the Serial-Queen Melodrama: The Etiology of an Anomaly". In Abel, Richard (ed.). Silent Film. New Brunswick, NJ: Rutgers University Press, 1996, pp. 163-193.

SORLIN, Pierre. Sociología del Cine - La apertura para la historia de mañana. Cidade do México: Fondo de Cultura Económica, 1985.

SPRINGER, Claudia. James Dean Transfigured: the many faces of rebel iconography. Austin: University of Texas Press, 2007.

STAIGER, Janet. Bad Women - Regulating Sexuality in Early American Cinema. Mineápolis/Londres: University of Minnesota Press, 1995.

STAM, Robert. "The prototype for Catherine - Helen Grund Hessel”. In: François Truffaut and Friends: Modernism, Sexuality, and Film Adaptation. Piscataway, NJ: Rutgers University Press, 2006, pp. 57-62.

TASKER, Yvonne. Spetacular bodies: gender, genre and the action cinema. Nova Iorque, Londres: Routledge, 1993.

THE U.S. EQUAL EMPLOYMENT OPPORTUNITY COMISSION. Sexual Harassment. 
Disponível via URL: www.eeoc.gov/types/sexual_harassment.html; acessado em $13 / 06 / 2009$.

THOMSON, David. Biography. Disponível via URL: http://www.jeannemoreau.com/bio.htm; acessado em 12/06/2010.

VIRILIO, Paul. “A força militar é determinada pela aparência”. In: . Guerra e Cinema. São Paulo: Página Aberta, 1993, pp. 09-19.

WEBER, Max. "A política como vocação". In: Ciência e política: duas vocações. São Paulo: Cultrix, 1993, pp. 53-124.

. Weber, Max. "Classe, estamento, partido". In: Ensaios de Sociologia. Rio de Janeiro: LTC: 2002, pp. 126-137.

. "Os três tipos puros de dominação legítima". In: Cohn, Gabriel (org.). Max Weber: Sociologia. São Paulo: Ática, 1991, pp. 128-141.

XAVIER, Ismail. "Corrosão social, pragmatismo e ressentimento: vozes dissonantes no cinema brasileiro de resultados". In: Novos Estudos - CEBRAP, N 75, 2006, pp. 139-155. . D.W.Griffith: o nascimento de um cinema. São Paulo: Brasiliense, 1984. . O discurso cinematográfico. A opacidade e a transparência. São Paulo: Paz e Terra, 2005. 


\section{Filmografia Principal}

Kill Bill Vol. 1 (título em português); Kill Bill: Vol. 1 (título original). Estados Unidos, 2003, 111 min. Dirigido por Quentin Tarantino.

Kill Bill Vol. 2 (título em português); Kill Bill: Vol. 2 (título original). Estados Unidos, 2004, 136 min. Dirigido por Quentin Tarantino.

Lara Croft: Tomb Raider (título original e em português). Reino Unido/Alemanha/Estados Unidos/Japão, 2001, 100 min. Dirigido por Simon West.

Lara Croft Tomb Raider: A origem da vida (título em português); Lara Croft Tomb Raider: The Cradle of Life (título original). Estados Unidos/Alemanha/Japão/Reino Unido/Holanda, 2003, 117 min. Dirigido por Jan de Bont.

Nikita - Criada para Matar (título em português); Nikita (título original, também intitulado La Femme Nikita). França/Itália, 1990, 115 min. Dirigido por Luc Besson.

Sedução e Vingança (título em português); Angel of Vengeance (título original, também intitulado Ms. 45). Estados Unidos, 1981, 81 min. Dirigido por Abel Ferrara.

Valente (título em português); The Brave One (título original). Estados Unidos, 2007, 122 min. Dirigido por Neil Jordan. 


\section{FiLMOGRAFIA DE APOIO}

A Fool There Was (título original). Estados Unidos, 1915, 67 min. Dirigido por Frank Powell.

Alien: o oitavo passageiro (título em português); Alien (título original). Estados Unidos, Reino Unido, 1979, 117 min. Dirigido por Ridley Scott.

Aliens, O Resgate (título em português); Aliens (título original). Estados Unidos, Reino Unido, 1986, 137 min. Dirigido por James Cameron.

Alien 3 (título em português); Alien $^{3}$ (título original). Estados Unidos, 1992, 114 min. Dirigido por David Fincher.

Algolagnia (título original). Brasil, 2006, 30 min. Dirigido por Túlio Bambino.

Anjos da Noite - A Evolução (título em português); Underworld: Evolution (título original). Estados Unidos, 2006, 106 min. Dirigido por Len Wiseman.

Assassina por natureza (título em português); The Job (título original). Estados Unidos, 2003, 83 min. Dirigido por Kenny Golde.

Ato de vingança (título em português); Rape Squad (título original, também intitulado Act of Vengeance). Estados Unidos, 1974, 90 min. Dirigido por Bob Kelljan.

Atração Fatal (título em português); Fatal Attraction (título original). Estados Unidos, 1987, 119 min. Dirigido por Adrian Lyne.

A vingança de Jennifer (título em português); I spit on your grave (título original, também intitulado Day of the Woman). Estados Unidos, 1978, 100 min. Dirigido por Meir Zarchi.

Blade Runner: o caçador de andróides (título em português). Blade Runner (título original). Estados Unidos, Hong Kong, 1982, 117 min. Dirigido por Ridley Scott.

Caroline Chérie (título original). França, 1951, 140 min. Dirigido por Richard Pottier.

Chapaev - O soldado vermelho (título em português); Чапаев (título original, também intitulado Chapaiev e Chapayev). Rússia, 1934, 93 min. Dirigido por Sergei Dimitrevitch e Georgi Nikolaevitch (também conhecidos como Sergei Vasilyev e Georgi Vasilyev).

Cleópatra Jones (título em portugûes); Cleopatra Jones (título original). Estados Unidos, 1973, 89 min. Dirigido por Jack Starrett.

Desejo de Matar (título em português); Death Wish (título original). Estados Unidos, 1974, 93 min. Dirigido por Michael Winner.

Femme Fatale (título original e em português). França, 2002, 114 min. Dirigido por Brian De Palma.

Foxy Brown (título original e em português). Estados Unidos, 1974, 94 min. Dirigido por Jack Hill. Halloween (título original e em português). Estados Unidos, 1978, 91 min. Dirigido por John Carpenter. 
Kramer x Kramer (título em português); Kramer vs. Kramer (título original). Estados Unidos, 1979, 105 min. Dirigido por Robert Benton.

Laranja Mecânica (título em português); A Clockwork Orange (título original). GrãBretanha/Estados Unidos, 1971, 136 min. Dirigido por Stanley Kubrick.

Matrix (título em português). The Matrix (título original). Estados Unidos, Austrália, 1999, 136 min. Dirigido por Andy Wachowski e Lana Wachowski.

Monster - Desejo Assassino (título em português); Monster (título original). Estados Unidos/Alemanha, 2003, 109 min. Dirigido por Patty Jenkins.

O Anjo Azul (título em português); Der Blaue Engel (título original). Alemanha, 1930, 124 min. Dirigido por Josef von Sternberg.

O Clã das Adagas Voadoras (título em português); Shi mian mai fu (título original). China, Hong Kong, 2004, 119 min. Dirigido por Yimou Zhang.

O Exterminador do Futuro 2 (título em português); Terminator 2: Judgement Day (título original). Estados Unidos, França, 1991, 137 min. Dirigido por James Cameron.

O Massacre da Serra Elétrica (título em português); The Texas Chain Saw Massacre (título original). Estados Unidos, 1974, 83 min. Dirigido por Tobe Hooper.

O Silêncio dos Inocentes (título em português); The Silence of the Lambs (título original). Estados Unidos, 1991, 118 min. Dirigido por Jonathan Demme.

Quarteto Fantástico (título em português); Fantastic Four (título original). Estados Unidos, Alemanha, 2005, 106 min. Dirigido por Tim Story.

Rei Arthur (título em português); King Arthur (título original). Estados Unidos, Reino Unido, Irlanda, 2004, 126 min. Dirigido por Antoine Fuqua.

Resident Evil - Apocalipse (título em português); Resident Evil: Apocalypse (título original). Alemanha, França, Reino Unido, Canadá, 2004, 94 min. Dirigido por Alexander Witt.

Rocky: o lutador (título em português); Rocky (título original). Estados Unidos, 1976, 119 min. Dirigido por John G. Avildsen.

Sin City - A Cidade do Pecado (título em português); Sin City (título original). Estados Unidos, 2005, 124 min. Dirigido por Frank Miller, Robert Rodriguez e Quentin Tarantino.

Sr. e Sra. Smith (título em português); Mr. \& Mrs. Smith (título original). Estados Unidos, 2005, 120 min. Dirigido por Doug Liman.

Thelma \& Louise (título original e em português). Estados Unidos, França, 1991, 130 min. Dirigido por Ridley Scott. 